\title{
ECOLOGICAL EVALUATION OF PROPOSED DISCHARGE OF DREDGED MATERIAL FROM OAKLAND HARBOR INTO OCEAN WATERS (PHIASE III A OF -42-FOOT PROJECT)
}

Volume 1 - Analyses and Discussion

\author{
J. A. Ward \\ J. Q. Word \\ M. R. Pinza \\ H. L. Mayhew \\ E. S. Barrows \\ L. F. Lefkovitz
}

Battelle/Marine Sciences Laboratory

Sequim, Washington

September 1992

Prepared for the U.S. Army Corps of Engineers under a Related Services Agreement with the U.S. Department of Energy Contract DE-ACO6-76RLO 1830

Pacific Northwest Laboratory

Richland, Washington 99352

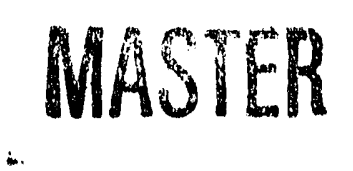

DISTRIBUTION OF THIS DOCUMENT IS UNLIMITED 


\section{PREFACE}

This is Volume 1 of a two-volume report that presents information gathered to determine the suitability of ocean disposal of sediment dredged from Oakland Harbor. This volume contains project background, materials and methods, results, discussions, and conclusions. Volume 2 contains the appendixes (A through $S$ ), which provide details of the data analyses and full presentation of the data and results. 


\section{SUMMARY}

During the summer and fall of 1990, the Battelle/Marine Sciences Laboratory (MSL) conducted a study to determine whether dredged sediments from Oakland Inner and Outer Harbors were suitable for ocean disposal following the guidelines of the Draft Ecological Evaluation of Proposed Discharge of Dredged Material into Ocean Waters, otherwise known as the Draft Implementation Manual (EPA/USACE 1990). Nineteen test treatments, six reference treatments, and three control treatments were tested for physical/chemical parameters, water column effects, dredged-sediment toxicity, and bicaccumulation potential.

Physical/chemical parameters were analyzed at each site and each composite sediment to a depth of $.44 \mathrm{ft}$ MLLW. These parameters included analysis for geological characteristics, conventional sediment measurements (grain size, total volatile solids, total organic carbon, oil and grease, and total petroleum hydrocarbons), metals, polynuclear aromatic hydrocarbons (PAHs), pesticides, butyltins, and polychlorinated biphenyls (PCBs). Physical/chemical data were used in support of the toxicological and bioaccumulation testing, but were not used in the decision-making criteria described in the Draft Implementation Manual under Tier III testing. To evaluate water column effects, MSL conducted suspended-particulate-phase (SPP) tests using the mysid shrimp Holmesimysis sculpta, speckled sanddab Citharichtys stigmaeus, and larvae of the pacific oyster Crassostrea gigas. Both a 48-h and a 96-h test were performed. The MSL evaluated dredgedsediment toxicity by conducting a total of eight solid-phase toxicity tests using the following organisms: the bivalve clam Macoma nasuta, the polychaete worm Nepthys caecoides, the speckled sanddab $C$. stigmaeus, and the amphipod Rhepoxynius abronius. Test duration ranged from 10 to 28 days. Bioaccumulation potential was evaluated in the 28-day $M$. nasuta and $N$. caecoides solid-p'.lase exposure." by measuring the contaminants of concern present in their tissues after exposure to test, reference, and control sediments. Because of low test organism survival, the 10- and 28-day $N$. caecoides exposures were rerun requiring resampling of Oakland Harbor sites and subsequent physical/chemical analysis. The physical/chemical results of the initial testing apply to the $M$. nasuta exposures; the retest physical/chemical results apply to the $N$. caecoides exposures.

The results of the initial physical/chemical analyses showed that the highest levels of conventional sediment measurements were present in test treatments I-C5, I-C9, I-S1, I-T1, and control treatment C-SB. Metal concentrations were also highest in test treatments I-C5, I-C9, I-S1, I-T1, and the inner bay sediment composite AC-3. Butyltin and PAH concentrations were highest in test treatments I-C5, I-S1, I-T1, and I-T5. Pesticides and PCBs were not present in 
significant amounts in any of the sediments. Retest results for physical/chemical analyses showed results similar to the initial testing, with test treatments I-T1, I-S1, and control treatment C-SB showing the highest levels of sediment conventionals, and test treatments I-S 1 and I-T1 containing the highest levels of metals. The PAH concentrations were highest in test treatments I-S1, I-T1, and in reference treatment R-AC. Pesticides and PCBs were not present.

The results of the three water column tests showed that a significant decrease in survival occurred only in the C. gigas test for treatment BC-4. The LC50 estimate associated with this treatment (a composite of Oakland Inner Harbor stations I-C9, I-C10, I-C1 1, and I-C12) was 91.9\% SPP. The significance of this LC50 estimate can be determined through the use of a mixing model that evaluates the potential for 0.01 of this LC50 (0.92\% SPP) existing at the edge of a disposal site after $4 \mathrm{~h}$. The MSL did not apply a mixing model as part of the work performed under contract to U.S. Army Corps of Engineers (USACE) San Francisco District.

The results of standard 10-day toxicological tests showed that significant decreases in test organism survival, as defined by the Draft Implementation Manual, were observed in 10 of the 19 test sediment treatments relative to at least one reference. Sediment treatments $\mathrm{I}-\mathrm{C} 15, \mathrm{I}-\mathrm{Cl}$, I$\mathrm{C} 17$, and I-C18 (all located within the maneuvering area) produced the most toxicological hits. Sediment treatments representing composites of Oakland Inner and Outer Harbors (AC-1 and AC3) did not produce significant test organism mortality relative to any reference.

The results of bioaccumulation testing using $M$. nasuta and $N$. caecoides showed statistically significant higher levels of contaminants of concern in all test treatments relative to at least one reference. The highest occurrences of elevated contaminants were observed in tissues exposed to test treatments I-S1, I-T1, and I-T3. The lowest occurrences of elevated potential were observed in test treatments I-C4 and I-C11. Test exposures with $N$. caecoides exhibited higher bioaccumulation potential than $M$. nasuta relative to reference exposures.

The summary results for the Oakiand Phase III A program indicate that 10 of the 19 test sediments showed significant decreases in test organism survival compared to at least one of the six references. Bioaccumulation of contaminants occurred in all treatments relative to at least one reference and was most prevalent in test treatments I-S1, I-T1, and I-T3. An overall comparison of test treatment acute toxicity and bioaccumulation to the references showed that the most toxicological hits were observed relative to the reference R-PC (Point Reyes Coarse); the fewest were associated with the reference R-AC (Alcatraz Island Disposal Site). This report provides the District Engineer of USACE and the Regional Administrator (USEPA) the information and analysis required for them to decide and concur on which sediments are acceptable for ocean disposal from the Oakland Inner Harbor deepening project. 


\section{ACKNOWLEDGMENTS}

The authors thank Mike Barrows, Dev Niyogi, Tom Parkwell, and Liam Antrim for the success of the laboratory testing. For many hours of careful data entry, proofreading, and preparation of data appendixes, we thank Heather Coley, Mike Hamilton, Ginger Hawkins, Elisa Sanderson, Shawn Sanderson, Lisa Karle, Jenny Bridge, and Dale Clark. Many thanks to Rob Cuello, Dick Ecker, Wayne Gorst, and Ron Thom for their careful reviews. We greatly appreciate the knowledge and competence of Michele Finney who carefully guided this report from its beginning stages uniil the final publication. 


\section{CONTENTS}

PREFACE $\ldots \ldots \ldots \ldots \ldots \ldots \ldots \ldots \ldots \ldots \ldots \ldots \ldots \ldots$ iii

SUMMARY $\ldots \ldots \ldots \ldots \ldots \ldots \ldots \ldots \ldots \ldots \ldots \ldots \ldots \ldots$

ACKNOWLEDGMENTS $\ldots \ldots \ldots \ldots \ldots \ldots \ldots \ldots \ldots \ldots \ldots \ldots$ vii

1.0 INTRODUCTION $\ldots \ldots \ldots \ldots \ldots \ldots \ldots \ldots \ldots \ldots \ldots \ldots \ldots \ldots \ldots$

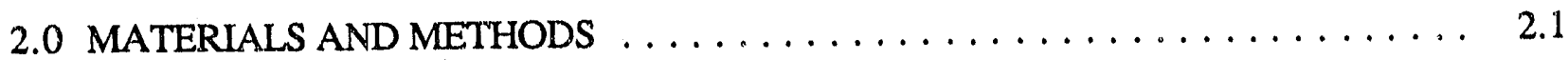

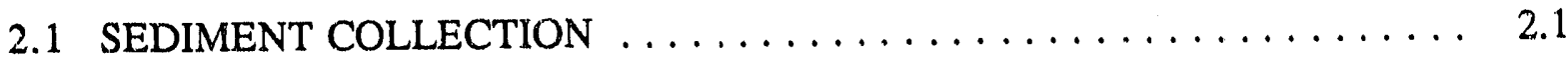

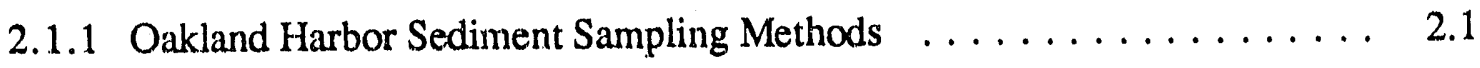

2.1.2 Reference and Control Sediment Collection . . . . . . . . . . . . 2.10

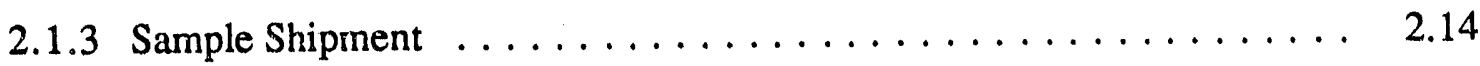

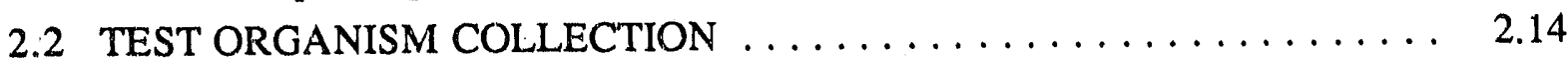

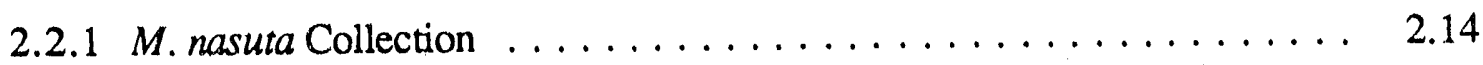

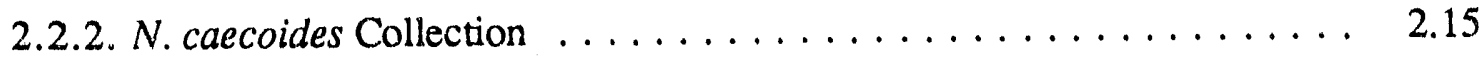

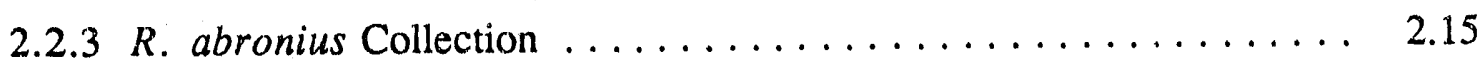

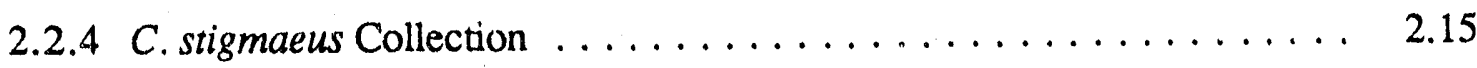

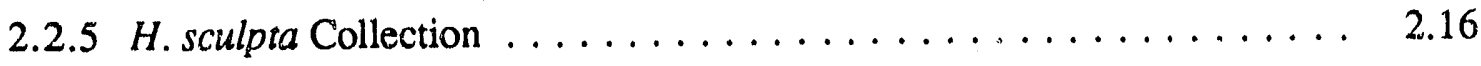

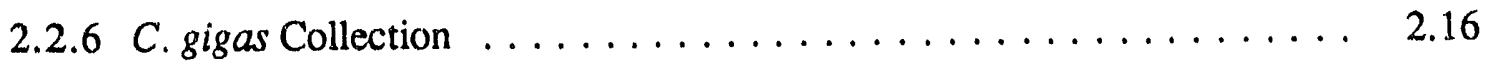

2.3 SAMPLE PREPARATION PROCEDURES $\ldots \ldots \ldots \ldots \ldots \ldots \ldots \ldots \ldots$

2.3.1 Laboratory Glassware and Equipment Preparation $\ldots \ldots \ldots \ldots \ldots . . \ldots 2.16$

2.3.2 Preparation of Samples for Solid-Phase Tests $\ldots \ldots \ldots \ldots \ldots \ldots . . \ldots 2.16$

2.3.3 Preparation of Samples for Suspended-Particulate-Phase Tests . . . . . 2.18

2.4 SEDIMENT AND TISSUE CHEMISTRY PROCEDURES $\ldots \ldots \ldots \ldots \ldots \ldots$

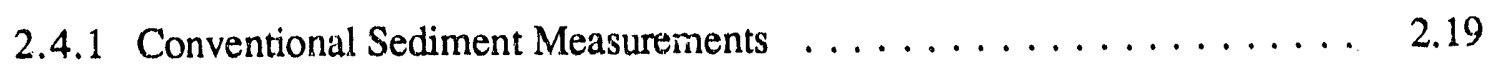

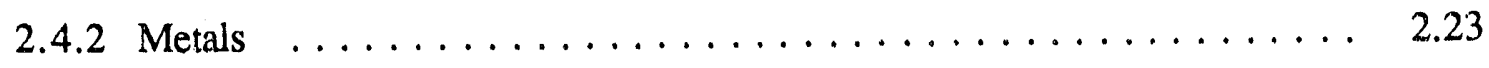

2.4.3 Chlorinated Pesticides and PCBs $\ldots \ldots \ldots \ldots \ldots \ldots \ldots . \ldots \ldots 2 . \ldots \ldots$

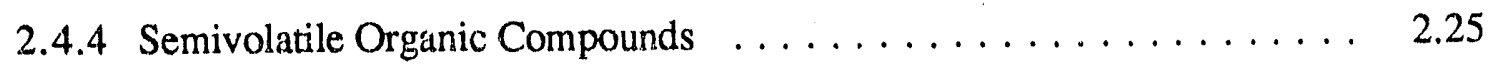

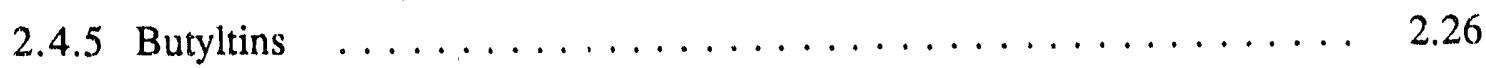

2.5 SOLID-PHASE TOXICOLOGICAL TESTING PROCEDURES $\ldots \ldots \ldots \ldots$

2.5.1 10- and 28-Day Solid-Phase Flow-Through Test With $M$. nasuta and $N$. caecoides . . . . . . . . . . . . . . . . . . . . 2.27

2.5.2 10-Day Solid-Phase Flow-Through Test with $C$. stigmaeus . . . . . . . 2.29

2.5.3 10-Day Solid-Phase Static and Flow-Through Tests with R. abronius _. 2.30 
2.6 SUSPENDED-PARTICULATE-PHASE TESTS $\ldots \ldots \ldots \ldots \ldots \ldots \ldots \ldots$

2.6.1 96-h Suspended-Particulate-Phase Static Test with H. sculpta $\quad \ldots \ldots \ldots$.

2.6.2 96-h Suspended-Particulate-Phase Static Test with C. stigmaeus . . . . 2.33

2.6.3 48-h Suspended-Particulate-Phase Static Test with Larval C. gigas . . . 2.34

2.7 DATA ANALYSIS AND INTERPRETATION $\ldots \ldots \ldots \ldots \ldots \ldots \ldots \ldots$

2.7 .1 Randomization $\ldots \ldots \ldots \ldots \ldots \ldots \ldots \ldots \ldots \ldots \ldots \ldots \ldots$

2.7.2 Statistical Analysis of Solid-Phase Tests . . . . . . . . . . . . . 2.36

2.7.3 Statistical Analysis of Suspended-Particulate-Phase Tests $\ldots \ldots \ldots \ldots . . .37$

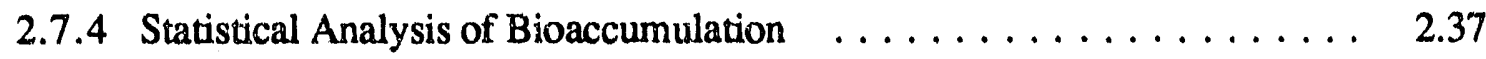

2.8 QUALITY ASSURANCE/QUALITY CONTROL PROCEDURES $\ldots \ldots \ldots . . .38$

2.8.1 Sample Tracking and Storage $\ldots \ldots \ldots \ldots \ldots \ldots \ldots \ldots \ldots \ldots . \ldots \ldots$

2.8.2 Sediment and Tissue Chemistry QA/QC Procedures $\ldots \ldots \ldots \ldots \ldots$

2.8.3 Toxicological Testing QA/QC Procedures $\ldots \ldots \ldots \ldots \ldots \ldots$

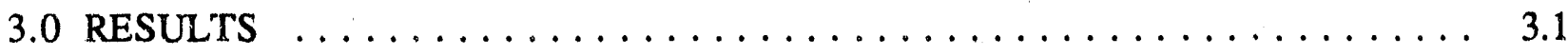

3.1 GEOLOGIC DESCRIPTION $\ldots \ldots \ldots \ldots \ldots \ldots \ldots \ldots \ldots \ldots \ldots \ldots \ldots$

3.1 .1 Older Bay Mud Unit $\ldots \ldots \ldots \ldots \ldots \ldots \ldots \ldots \ldots \ldots$

3.1 .2 Sand Deposits $\ldots \ldots \ldots \ldots \ldots \ldots \ldots \ldots \ldots \ldots \ldots \ldots \ldots$

3.1 .3 Younger Bay Mud Unit $\ldots \ldots \ldots \ldots \ldots \ldots \ldots \ldots \ldots$

3.1 .4 Geologic Analysis $\ldots \ldots \ldots \ldots \ldots \ldots \ldots \ldots \ldots \ldots . \ldots \ldots$

3.2 RESULTS OF PHYSICAL AND CHEMICAL ANALYSES ON

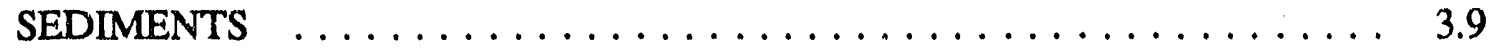

3.2.1 Conventional Measurements for Sediment Analysis $\ldots \ldots \ldots \ldots \ldots \ldots$

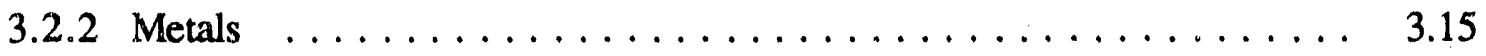

3.2.3 Chlorinated Pesticides and PCBs . . . . . . . . . . . . . . 3.24

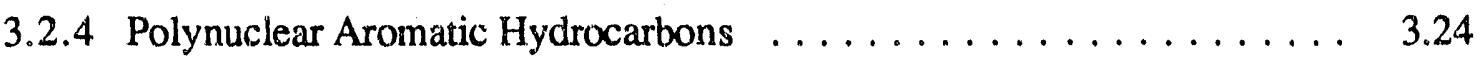

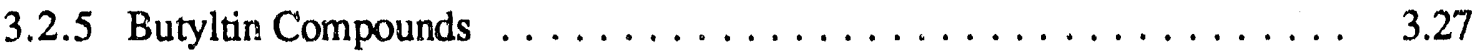

3.3 RETEST RESULTS OF PHYSICAL AND CHEMICAL ANALYSES ON
SEDIMENTS $\ldots \ldots \ldots \ldots \ldots \ldots \ldots \ldots \ldots \ldots \ldots \ldots \ldots \ldots \ldots \ldots \ldots \ldots \ldots \ldots \ldots \ldots$

3.3.1 Conventional Measurements for Sediment Analysis (Retest) . . . . . 3.27

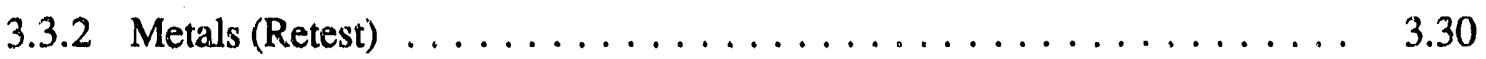

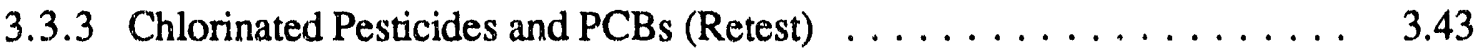

3.3 .4 PAHs (Retest) $\ldots \ldots \ldots \ldots \ldots \ldots \ldots \ldots \ldots \ldots \ldots \ldots$

3.3.5 Butyltins (Retest) $\ldots \ldots \ldots \ldots \ldots \ldots \ldots \ldots \ldots \ldots . \ldots \ldots$

PHASE IUA $\quad x$ 
3.4.1 10-Day Solid-Phase Flow-Through Test with $M$. nasuta and

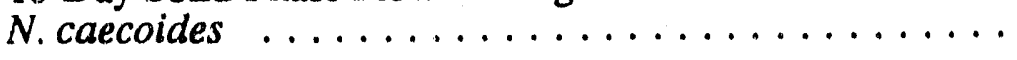

3.4.2 28-Day Solid-Phase Flow-Through Test with $M$. nasuta and. $N$. caecoides

3.4.3 10-Day Solid-Phase Flow-Through Retest with $M$. nasuta and

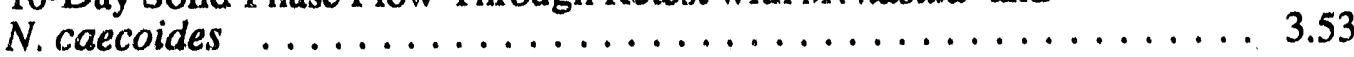

3.4.4 28-Day Solid-Phase Flow-Through Retest with $M$. nasuta and N. caecoides ....................... 3.56

3.4.5 10-Day Solid-Phase Flow-Through Test with C. stigmaeus $\ldots \ldots \ldots \ldots .3 .56$

3.4.6 10-Day Solid-Phase Flow-Through Test with $R$. abronius (with Aeration) . . . . . . . . . . . . . . . . . 3.57

3.4.7 10-Day Solid-Phase Flow-Through Test with $R$. abronius (without Aeration) . . . . . . . . . . . . . . . . . . . 3.60

3.4.8 10-Day Solid-Phase Static Test with $R$. abronius (with Aeration) . . . . . . . . . . . . . . . . . . . . . . . 3.60

3.5 SUSPENDED-PARTICULATE-PHASE TESTS $\ldots \ldots \ldots \ldots \ldots \ldots \ldots . \ldots . \ldots 3$

3.5.1 96-h Suspended-Particulate-Phase Static Test with $H$. sculpta $\ldots \ldots$. . 3.63

3.5.2 96-h Suspended-Particulate-Phase Static Test with $C$. stigmaeus $\ldots \ldots . .63$

3.5.3 48-h Suspended-Particulate-Phase Static Test with Larval $C$ gigas . . . . . . . . . . . . . . . . . . . 3.65

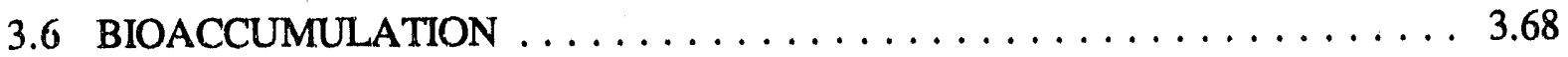

3.6.1 Polynuclear Aromatic Hydrocarbon Bioaccumulation in $M$. nasuta . . . . . 3.68

3.6.2 Pesticide and PCB Bioaccumulation in M. nasuta . . . . . . . . . 3.73

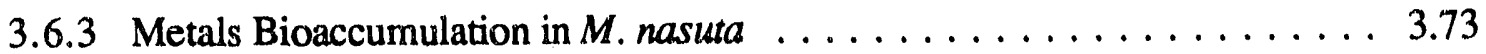

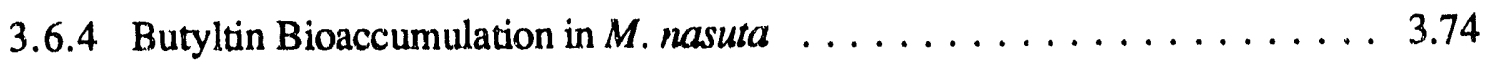

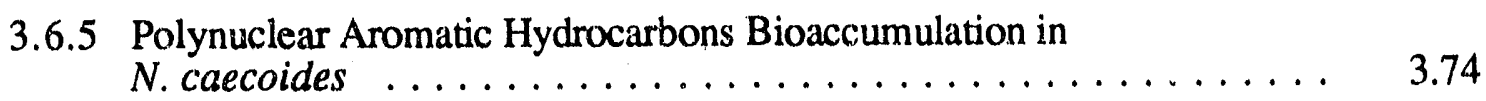

3.6.6 Pesticide and PCB Bioaccumulation in $N$. caecoides . . . . . . . 3.77

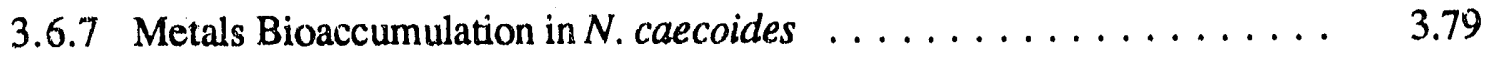

3.6.8 Butyltins Bioaccumulation in $N$. caecoides $\ldots \ldots \ldots \ldots \ldots \ldots . \ldots . \ldots$

4.0 DISCUSSION AND CONCLUSIONS $\ldots \ldots \ldots \ldots \ldots \ldots \ldots \ldots \ldots \ldots \ldots \ldots$

4.1 GEOLOGY OF PROPOSED DREDGED SEDIMENTS $\ldots \ldots \ldots \ldots \ldots \ldots \ldots .4 .1$

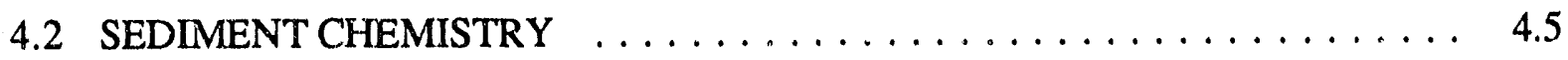

4.3 TOXICOLOGY AND BIOACCUMULATION $\ldots \ldots \ldots \ldots \ldots \ldots \ldots \ldots$

4.3.1 Comparison of Test Treatments to the Reference Sediment R-AC . . . . 4.7

4.3.2 Comparison of Test Treatments to the Reference Sediment R-AM . . . . 4.7 
4.3.3 Comparison of Test Treatments to the Refer ance Sediment R-BF . . . . . . 4.7

4.3.4 Comparison of Test Treatments to the Reference Sediment R-OS . . . . . 4.11

4.3.5 Comparison of Test Treatments to the Reference Sediment R-PC . . . . . 4.11

4.3.6 Comparison of Test Treatments to the Reference Sediment R-PF . . . . . 4.14

4.4 CONCLUSIONS $\ldots \ldots \ldots \ldots \ldots \ldots \ldots \ldots \ldots \ldots \ldots \ldots \ldots \ldots . \ldots \ldots$

4.4.1 Water Column $\ldots \ldots \ldots \ldots \ldots \ldots \ldots \ldots \ldots \ldots \ldots . \ldots \ldots$

4.4.2 Deposited Sediment Toxicity $\ldots \ldots \ldots \ldots \ldots \ldots \ldots . \ldots \ldots$

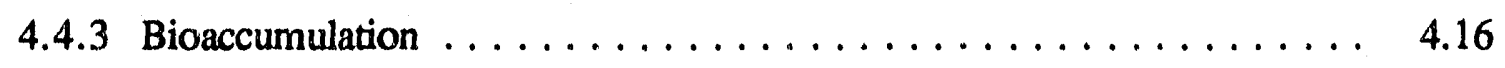

5.0 REFERENCES $\ldots \ldots \ldots \ldots \ldots \ldots \ldots \ldots \ldots \ldots \ldots \ldots \ldots \ldots \ldots \ldots \ldots \ldots$

PHASE ILA $\quad$ xii 


\section{FIGURES}

1.1 Oakland Phase III A Study Area $\ldots \ldots \ldots \ldots \ldots \ldots \ldots \ldots \ldots \ldots \ldots \ldots$

2.1 Oakland Phase III A Inner and Outer Harbor Sampling Stations $\ldots \ldots \ldots \ldots$

2.2 Six Sampling Stations Located Within the Bay Farm Borrow Area $\ldots . . \ldots . . .2 .3$

2.3 Sampling Stations R-AM and R-AC (Alcatraz Disposal Site) $\ldots \ldots \ldots \ldots \ldots$

2.4 Location of Offshore Reference Stations $\ldots \ldots \ldots \ldots \ldots \ldots \ldots \ldots$

2.5 Components of the 4-in. and 12-in. Vibratory-Hammer Coring Devices . . . . . . 2.7

2.6 Location of Sequim Bay, Washington, Control Station (C-SB) . . . . . . . . . 2.11

2.7 Location of West Beach, Whidbey Island, Washington, Control Station (C-WB) . . 2.12

2.8 Location of Tomales Bay, California, Control Station (C-NE) . . . . . . . . . 2.13

2.9 Flow-Through Aquarium For $M$. nasuta, $N$. caecoides, and $C$. stigmaeus $\ldots \ldots 2.28$

2.10 Static and Flow-Through Amphipod Testing Jars $\ldots \ldots \ldots \ldots \ldots \ldots \ldots$

3.1 Positions of Cross Sections A Through D Located Within the Inner Harbor $\ldots \ldots \ldots .2$

3.2 Oakland Phase III A Geologic Cross Section A-A $\ldots \ldots \ldots \ldots \ldots \ldots$

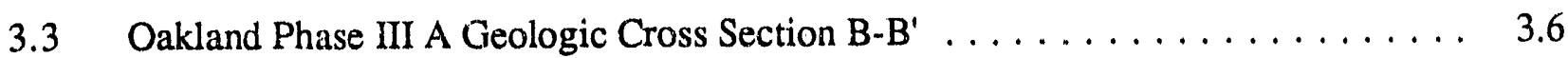

3.4 Oakland Phase III A Geologic Cross Section C-C $\ldots \ldots \ldots \ldots \ldots \ldots \ldots$

3.5 Oakland Phase III A Geologic Cross Section D-D' . . . . . . . . . . . . 3.8

3.6 Results of Sediment Grain Size Analysis of Oakland Phase III A Sediment Treatments ............................. 3.11

3.7 Concentrations of TOC Found in Oakland Phase III A Sediment Treatments . . . . 3.12

3.8 Linear Regression Showing the Relationship Between Sediment Grain Size and TOC in Oakland Phase III A Sediment Treatments . . . . . . . . . . . . . . 3.12

3.9 Concentrations of 'TVS Found in Oakland Phase III A Sediment Treatments . . . . 3.13

3.10 Linear Regression Showing the Relationship Between TOC and TVS in Oakland Phase III A Sediment Treatments . . . . . . . . . . . . . . . . . . . 3.14

3.11 Concentrations of Oil and Grease Found in Oakland Phase III A Sediment $\ldots \ldots \ldots \ldots \ldots \ldots$

3.12 Concentrations of TPH Found in Oakland Phase III A Sediment Treatments . . . . 3.16

3.13 Linear Regression Showing the Relationship Between Oil and Grease and TPH in Oakland Phase III A Sediment Treatments . . . . . . . . . . . . . 3.16

3.14 Linear Regression Showing the Relationship Between TPH and TOC in Oakland Phase III A Sediment Treatments . . . . . . . . . . . . . . . . . . . . 3.17

3.15 Concentrations of Silver Found in Oakland Phase III A Sediment Treatments . . . 3.17

3.16 Concentrations of Arsenic Found in Oakland Phase III A Sediment Treatments . . 3.19

3.17 Concentrations of Cadmium Found in Oakland Phase III A Sediment Treatments . . 3.19

PHASE IIIA $\quad$ xiii 
3.18 Concentrations of Chromium Found in Oakland Phase III A Sediment Treatments . $\quad 3.21$

3.19 Concentrations of Copper Found in Oakland Phase III A Sediment Treatments . . . 3.21

3.20 Concentrations of Mercury Found in Oakland Phase III A Sediment Treatments . . . 3.22

3.21 Concentrations of Nickel Found in Oakland Phase III A Sediment Treatments . . . 3.22

3.2. Concentrations of Lead Found in Oakland Phase III A Sediment Treatments . . . . 3.23

3.23 Concentrations of 'Zinc Found in Oakland Phase III A Sediment Treatments . . . . 3.24

3.24 Concentrations of LPAH Found in Oakland Phase III A Sediment Treatments . . . 3.25

3.25 Concentrations of HPAH Found in Oakland Phase III A Sediment Treatments . . . 3.26

3.26 Concentrations of LPAH and HPAH Found in Oakland Phase III A Sediment Treatments $\ldots \ldots \ldots \ldots \ldots \ldots \ldots \ldots \ldots \ldots \ldots \ldots \ldots \ldots$

3.27 Concentrations of Monobutyltin Found in Oakland Phase III A Sediment Treatments ............................... 3.28

3.28 Concentrations of Dibutyltin Found in Oakland Phase III A Sediment Treatment . . 3.28

3.29 Concentrations of Tributyltin Found in Oakland Phase III A Sediment Treatment . . 3.29

3.30 Results of Sediment Grain Size Analysis of Oakland Harbor Phase III A Retest Sediment Treatments $\ldots \ldots \ldots \ldots \ldots \ldots \ldots \ldots \ldots \ldots \ldots \ldots \ldots \ldots \ldots$

3.31 Concentrations of TOC Found in Oakland Phase III A Retest Sediment Treatments . . . . . . . . . . . . . . . . . . . . . . . 3.32

3.32 Linear Regression Showing the Relationship Between Grain Size and TOC in Oakland Phase III A Retest Sediment Treatments . . . . . . . . . . . . . . . 3.32

3.33 Concentrations of TVS Found in Oakland Phase III A Retest Sediment Treatments . 3.33

3.34 Linear Regression Showing the Relationship Between TOC and TVS in Oakland Phase III A Retest Sediment Treatments $\ldots \ldots \ldots \ldots \ldots \ldots \ldots \ldots \ldots \ldots \ldots$

3.35 Concentrations of Oil and Grease Found in Oakland Phase III A Retest Sediment Treatments . . . . . . . . . . . . . . . . . . . . . .

3.36 Concentrations of TPH Found in Oakland Phase III A Retest Sediment Treatments . . . . . . . . . . . . . . . . . . . . . . . . . . . 3.34

3.37 Linear Regression Showing the Relationship Between Oil and Grease and TPH in Oakland Phase III A Retest Sediment Treatments . . . . . . . . . . . . . . 3.35

3.38 Linear Regression Showing the Relationship Between TPH and TOC in Oakland Phase III A Retest Sediment Treatments . . . . . . . . . . . . . . . . . . 3.35

3.39 Concentrations of Silver Found in Oakland Phase III A Retest Sediment Treatments . . . . . . . . . . . . . . . . . . . . . . . . . 3.36

3.40 Concentrations of Arsenic Found in Oakland Phase III A Retest Sediment Treatments . . . . . . . . . . . . . . . . . . . . . . . . 3.37

3.41 Concentrations of Cadmium Found in Oakland Phase III A Retest Sediment

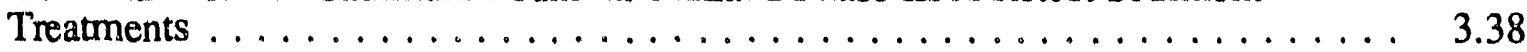

3.42 Concentrations of Chromium Found in Oakland Phase III A Retest Sediment Treatments . . . . . . . . . . . . . . . . . . . . . . . 
3.43 Concentrations of Copper Found in Oakland Phase III A Retest Sediment

Treatments

3.44 Concentrations of Mercury Found in Oakland Phase III A Retest Sediment

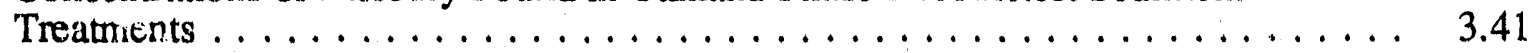

3.45 Concentrations of Nickel Found in Oakland Phase III A Retest Sediment Treatments . . . . . . . . . . . . . . . . . . . . . . . . 3.41

3.46 Concentrations of Lead Found in Oakland Phase III A Retest Sediment Treatments . . . . . . . . . . . . . . . . . . . . . . . . . 3.42

3.47 Concentrations of Zinc Found in Oakland Phase III A Retest Sediment Treatments . . . . . . . . . . . . . . . . . . . . . . . . . 3.42

3.48 Concentrations of Aroclor 1254 Found in Oakland Phase III A Retest Sediment Treatments . . . . . . . . . . . . . . . . . . . . . . . . 3.44

3.49 Concentrations of LPAH Found in Oakland Phase III A Retest Sediment Treatments ............................. 3.45

3.50 Concentrations of HPAH Found in Oakland Phase III A Retest Sediment

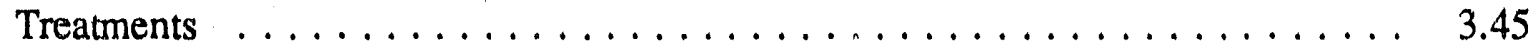

3.51 Concentrations of LPAH and HPAH Found in Oakland Phase III A Retest Sediment Treatments $\ldots \ldots \ldots \ldots \ldots \ldots \ldots \ldots \ldots \ldots \ldots \ldots \ldots \ldots$

3.52 Concentrations of Monobutyltin Found in Oakland Phase III A Retest Sediment

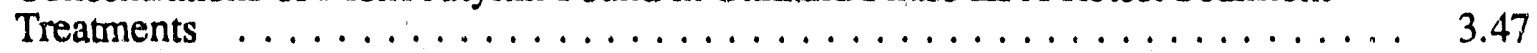

3.53 Concentrations of Dibutyltin Found in Oakland Phase III A Retest Sediment Treatments . . . . . . . . . . . . . . . . . . . . . 3.47

3.54 Concentrations of Tributyltin Found in Oakland Phase III A Retest Sediment

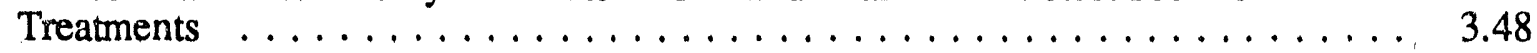

4.1 Oakland Phase III A Inner and Outer Harbor Sampling Stations $\ldots \ldots$. . . . . . . 4.2

4.2 Oakland Inner Harbor Geologic Cross Sections $\ldots \ldots \ldots \ldots \ldots . \ldots \ldots$ 


\section{TABLES}

2.1 Sediment Sample Identification Codes and Analyses $\ldots \ldots \ldots \ldots \ldots \ldots .2 .6$

2.2 Analytical Chemistry Requirements for Oakland Harbor Sediment Samples . . . . . . 2.20

2.3 Analytical Chemistry Requirements for Oakland Harbor Tissue Samples $\ldots \ldots .2 .21$

2.4 Grain Size Fractions Measured $\ldots \ldots \ldots \ldots \ldots \ldots \ldots \ldots \ldots \ldots \ldots \ldots \ldots \ldots \ldots \ldots \ldots .22$

2.5 Analytical Method and Corresponding Metal for Each Sample Matrix $\ldots \ldots \ldots 2.25$

3.1 Summary of Results of Grain Size Analyses of Oakland Phase III A Sediment

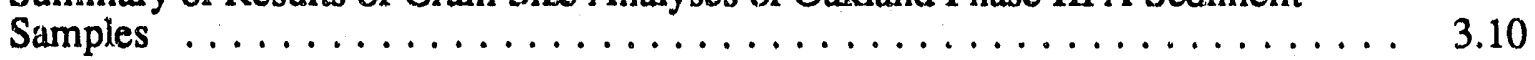

3.2 Oakland Harbor Phase III A Seliment Treatments with Silver Concentrations Exceeding Those Found in Typical Shale Soil $\ldots \ldots \ldots \ldots \ldots \ldots \ldots \ldots, 3.18$

3.4 PCB Concentrations Found in Oakland Phase III A Sediment Treatments . . . . . 3.25

3.5 Summary of Results of Grain Size Analysis of Oakland Harbor Phase III A Retest Sediment Samples ............................. 3.30

3.6 Oakland Harbor Phase III A Retest Sediment Treatments with Silver Concentrations Exceeding Those Found in Typical Shale Suil $\ldots \ldots \ldots \ldots \ldots \ldots \ldots \ldots . . \ldots .36$

3.7 Oakland Harbor Phase III A Retest Sediment Treatments with Cadmium Concentrations Exceeding Those Found in Typical Shale Soil .............

3.8 Oakland Harbor Phase III A Retest Sediment Treatments with Zinc Concentrations Exceeding Those Found in Typical Shale Soil $\ldots \ldots \ldots \ldots \ldots \ldots \ldots \ldots . \quad 3.43$

3.9 PCB Concentrations Found in Oakland Phase III A Retest Sediment Treatments . . 3.44

3.10 Total of PAHI Concentrations for the Three Highest Sediment Treatments . . . . 3.46

3.11 Concentrations of Butyltins in Three Oakland Phase III A Retest Sediment Treatments .................................. 3.48

3.12 Resuits of 10-Day Solid-Phase Flow-Through Test With $M$. nasuta . . . . . . 3.50

3.13 ANOVA Results for the 10-Day Solid-Phase Flow-Through Test With M. nasuta . 3.50

3.14 Results of 10-Day Solid-Phase Flow-Through Test With $N$. caecoides . . . . . . 3.51

3.15 Results of 28-Day Solid-Phase Flow-Through Test With $M$. nasuta
and $N$. caecoides $\ldots \ldots \ldots \ldots \ldots \ldots \ldots \ldots \ldots \ldots \ldots \ldots \ldots \ldots \ldots \ldots$

3.16 Results of 10-Day Solid-Phase Flow-Through Retest With $M$. nasuta $\ldots \ldots \ldots 3.54$

3.17 ANOVA Resul/s for the 10-Day Solid-Phase Flow-Through Retest With

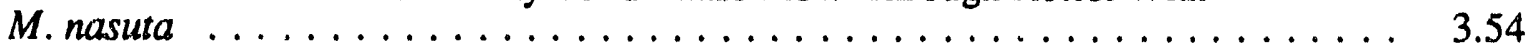

3.18 Results of 10-Day Solid-Phase Flow-Through Retest With $N$. caecoides $\ldots \ldots$. . 3.55

3.19 ANOVA Results for the 10-Day Solid-Phase Flow-Through Retest

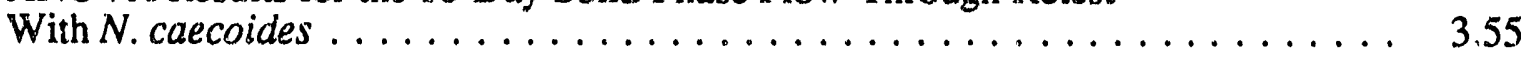

3.20 Results of the 28-Day Solid-Phase Flow-Through Retest With $M$. nasuta

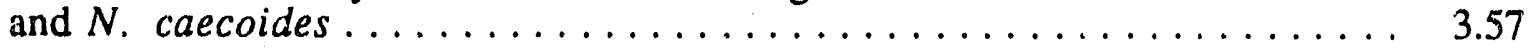

3.21 Results of the 10-Day Solid-Phase Flow-Through Test With C. stigmaeus $\ldots \ldots 3.58$ 
3.22 ANOVA Results for the 10-Day Solid-Phase Flow-Through Test With

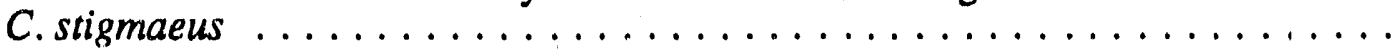

3.23 Results of the 10-Day Solid-Phase Flow-Through Test with $R$. abronius

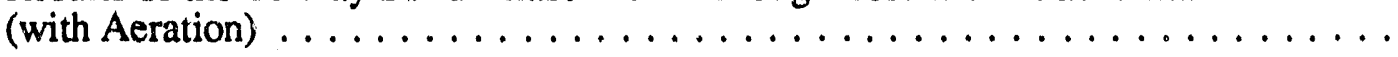

3.24 ANOVA Results for the 10-Day Solid-Phase Flow-Through Test With R. abronius

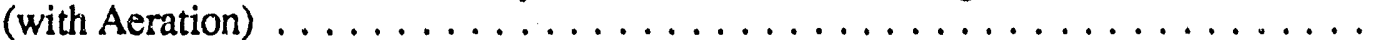

3.25 Results of the 10-Day Solid-Phase Flow-Through Test with $R$. abronius (without Aeration) .........................

3.26 ANOVA Results for the 10-Day Solid-Phase Flow-Through Test With $R$. abronius

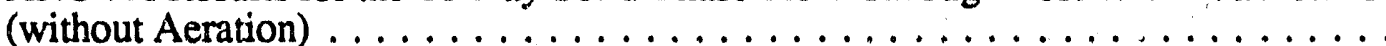

3.27 Results of the 10-Day Solid-Phase Static Test with R. abronius (with Aeration) . . .

3.28 ANOVA Results for the 10-Day Solid-Phase Static Test with $R$. abronius

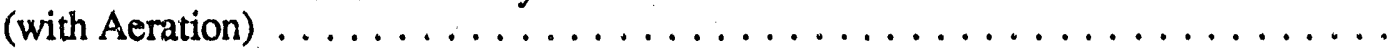

3.29 Results of the H. sculpta Suspended-Particulate-Phase Test . . . . . . . . . . . . 3.64

3.30 T-Test and LC50 Determinations for H. sculpta Suspended-Particulate-Phase

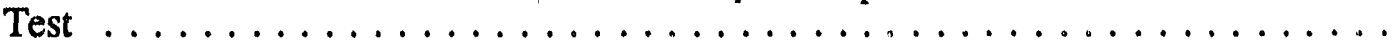

3.31 Results of the $C$. stigmaeus Suspended-Particulate-Phase Test . . . . . . . . . 3.66

3.32 T-Test and LC50 Determinations for the $C$. stigmaeus Test . . . . . . . . . . . 3.C6

3.33 Results of the $C$. gigas Suspended-Particulate-Phase Test $\ldots \ldots \ldots \ldots \ldots$

3.34 T-Test and LC50 Determinations for C. gigas Test Based on Percent Survival . . . 3.67

3.35 Mean Low Molecular Weight PAH and PCB (Aroclor 1254 and Aroclor 1260) Concentrations in the Tissues of $M$. nasuta $\ldots \ldots \ldots \ldots . \ldots \ldots$

3.36 Mean High Molecular Weight PAH Concentrations in the Tissues of $M$. nasuta . . 3.70

3.37 PAHs and PCBs in Tissues of $M$. nasuta That Are Significantly Different from Reference Tissue Concentrations Using Dunn's Test for Comparison of All Means Analysis . . . . . . . . . . . . . . . . . . .

3.38 Mean Metals Concentrations in the Tissues of $M$. nasuta . . . . . . . . . . .

3.39 Metals in Tissues of $M$. nasuta That Are Significantly Different from Reference Tissue Concentrations Using Dunn's Test for Comparison of All Means Analysis

3.40 Mean Butyltins Concentrations in the Tissues of $M$. nasuta . . . . . . . . . . .

3.41 Butyltins in Tissues of $M$. nasuta That Are Significantly Different from Reference Tissue Concentrations Using Dunn's Test for Comparison of All Means Analysis

3.42 Mean Low Molecular Weight PAH and PCB Aroclor 1254 Concentrations in the Tissues of $N$. caecoides

3.43 Mean High Molecular Weight PAH Concentrations in Tissues of $N$. caecoides . . .

3.44 PAHs and PCBs in Tissues of $N$. caecoides That Are Significantly Dirferent from Reference Tissue Concentrations Using Dunn's Test for Comparison

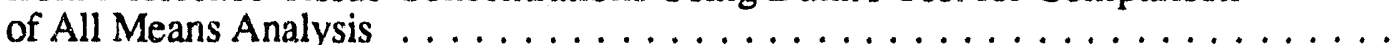

3.45 Mean Metals Concentrations in the Tissues of $N$. caecoides 
3.46 Metals in Tissues of $N$. caecoides That Are Significantly Different from Reference Tissue Concentrations Using Dunn's Test for Comparison of All Means

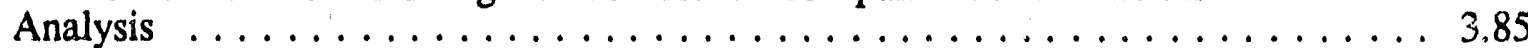

3.47 Mean Butyltins Concentrations in Tissues of $N$ caecoides $\ldots \ldots \ldots \ldots \ldots . \ldots 37$

3.48 Butyltins in Tissues of $N$. caecoides That Are Significantly Different from Reference Tissue Concentrations Using Dunn's Test for Comparison of All Means Analysis . . . . . . . . . . . . . . . . . . . . . . . . 3.88

4.1 Summary of Geological Descriptions for Inner Oakland Harbor Stations . . . . . . . 4.4

4.2 Summary of Toxicological and Bioaccumulation Hits for Each Reference . . . . . . 4.6

4.3 Summary of Significant Acute Toxicity and Bioaccumulation for Test Treatments Relative to the Reference $\mathrm{R}-\mathrm{AC} \ldots \ldots \ldots \ldots \ldots \ldots \ldots \ldots \ldots$

4.4 Summary of Significant Acute Toxicity and Bioaccumulaticn for Test Treatments Relative to the Reference R-AM . . . . . . . . . . . . . . . . . . . . . . . . 4.9

4.5 Summary of Significant Acute Toxicity and Bioaccumulation for Test Treatments Relative to the Reference R-BF . . . . . . . . . . . . . . . . . . . . . . . . . 4.10

4.6 Summary of Significant Acute Toxicity and Bioaccumulation for Test Treatments Relative to the Reference R-OS . . . . . . . . . . . . . . . . . . . . . . 4.12

4.7 Summary of Significant Acute Toxicity and Bioaccumulation for Test Treatments Relative to the Reference R-PC . . . . . . . . . . . . . . . . . . . . . . 4.13

4.8 Summary of Significant Acute Toxicity and Bioaccumulation for Test Treatments

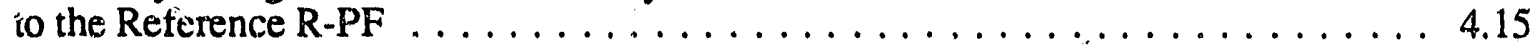




\subsection{INTRODUCTION}

The Water Resources Development Act of 1986 (Public Law 99-662) authorized the U.S. Army Corps of Engineers (USACE), San Francisco District, to deepen and widen the navigation channels of the Oakland Inner and Outer Harbors to accommodate deeper-draft vessels. Oakland Harbor is a 4.5-mile-long shipping channel located between the cities of Oakland and Alameda, California, bordering the eastern shoreline of San Francisco Bay (Figure 1.1).

The Oakland Harbor navigation channels are to be deepened from the currently authorized water depth of $-35 \mathrm{ft}$ Mean Lower Low Water (MLLW) to $-42 \mathrm{ft}$ MLLW (plus $2 \mathrm{ft}$ of overdepth) to provide suitable berthing areas and turning basins. The deepening of Oakland Inner Harbor will occur in two phases. The first phase will deepen the harbor to $-39 \mathrm{ft} M L L W(-38 \mathrm{ft}$ plus $1 \mathrm{ft}$ overdepth); the second phase will deepen the harbor to $-42 \mathrm{ft} M L L W$ (plus $2 \mathrm{ft}$ overdepth). The USACE is considering several options for disposal of the dredged material, including open-ocean disposal, disposal in an upland site, or disposal in San Francisco Bay.

Section 103 of the Marine Protection, Research, and Sanctuaries Act of 1972 (MPRSA), Public Law 92-532, specifies that all proposed disposal of dredged material into ocean waters be evaluated to determine the potential environmental impact of those activities. The Secretary of the Army performs these evaluations using criteria published by the U.S. Environmental Protection Agency (EPA) in Title 40 of the Code of Feders! Regulations, Parts 220-228 (40 CFR 220-228). To comply with these requirements, the potential harmfil effects resulting from the disposal of these sediments must be evaluated by toxicity and bioaccumulation testing prior to sediment disposal. These tests provide relatively direct estimates of the potential for environmental impacts. Testing is to be performed under the guidance of the Draft Ecological Evaluation of Proposed Discharge of Dredged Material into Ocean Waters (EPA/USACE 1990), hereinafter referred to as the Draft Implementation Manual.

The Battelle/Marine Sciences Laboratory (MSL),(a) operating under contract to USACE, has completed the following three ecological evaluations of Oakland Harbor sediments under guidance of the earlier Implementation Manual (EPA/USACE 1977):

- 38-Foot Project - testing of sediments collected in Oakland Inner Harbor to project depths of -38 ft MLLW (Word et al. 1988)

(a) The Marine Sciences Laboratory is part of the Pacific Northwest Laboratory, which is operated for the U.S. Department of Energy by Battelle Memorial institute. 


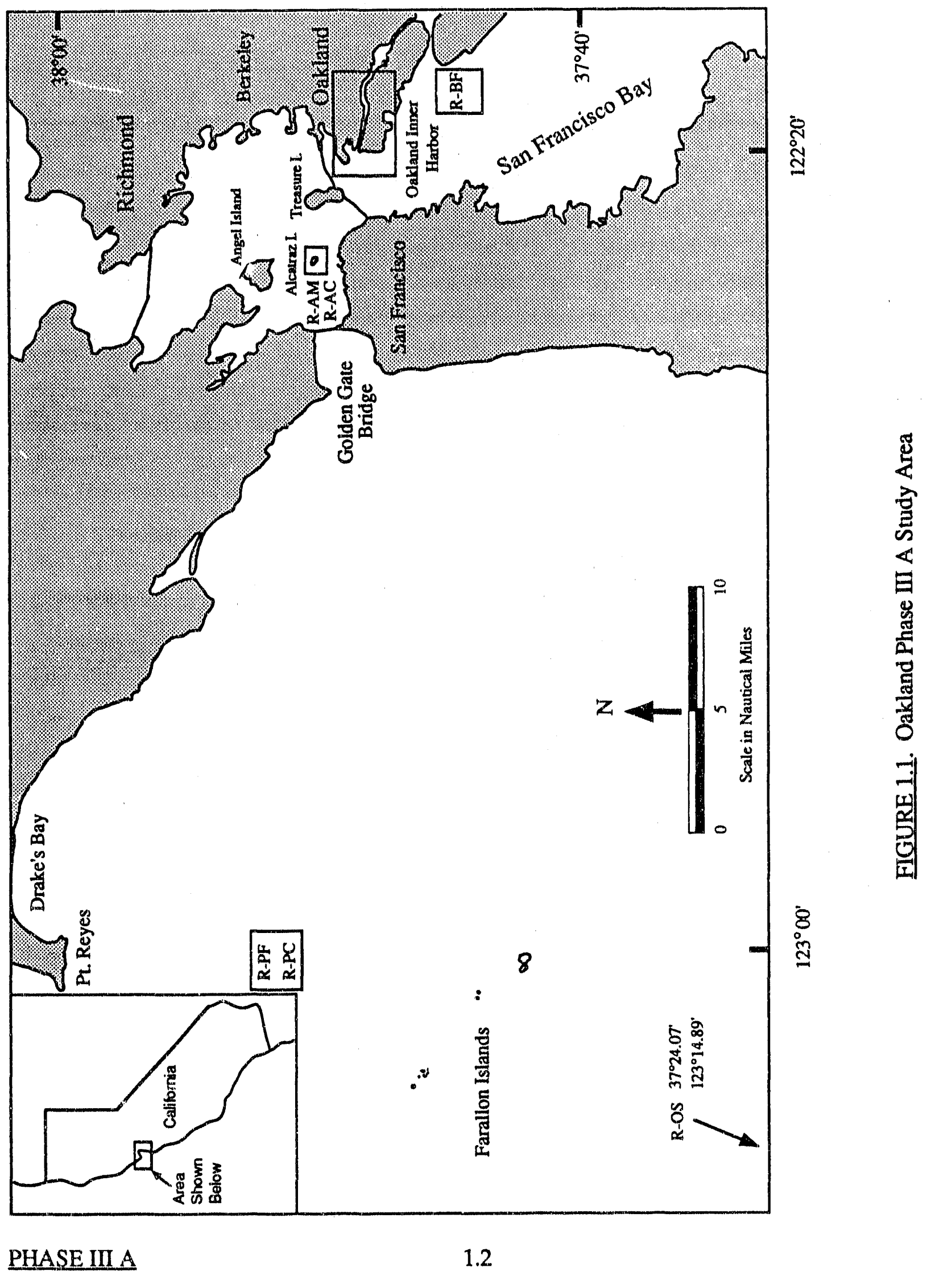


- Phase I - testing of sediments collected in Oakland Inner Harbor to project depths of $-42 \mathrm{ft}$ MLLW (Word et al. 1990a)

- Phase II - testing of sediments collected in Oakland Outer Harbor to project depths of $-42 \mathrm{ft}$ MLLW (Word et al. 1990b).

Since the completion of the 38-Foot Project and Phases I and II of the Oakland Harbor Testing Program, USACE has requested that MSL conduct a fourth ecological evaluation (Phase III) to sample new sites within the harbor, resample sites included in the previous evaluation, and conduct chemical and biological evaluations of the sediments collected according to the Draft Implementation Manual protocols (EPA/USACE 1990). The Oakland Phase III Program is divided into three parts, $\mathrm{A}, \mathrm{B}$, and the -38-ft Program. The objective of Phase III A was to evaluate sediment samples collected in the maneuvering area, turning basin, and channel area of Oakland Inner Harbor. The objective of Phase III B was to collect sediment samples and test organisms for evaluation of sediments in the channel area that will be deepened and widened in Oakland Outer Harbor. The -38-ft Program evaluated sediment in Oakland Inner Harbor from mudline to $-39 \mathrm{ft}$ MLLW (-38 ft plus $1 \mathrm{ft}$ overdepth). This report summarizes the results of field and laboratory activities conducted under Phase III A of the program. Another report summarizes field and laboratory i ctivities conducted under Phase III B of the Oakland Harbor Program (Kohn et al. 1992). The Phase III -38-ft information was presented in an additional report to USACE (Ward et al. 1992) with a statistical comparison of the data to the Alcatraz Island Dredged Material Disposal Site Environs (Mayhew et al. 1992).

Core samples representing dredged material were collected from Oakland Inner Harbor in support of the Oakland Harbor Phase III A Project. Additional samples were also collected in Oakland Outer Harbor in support of the Oakland Waterways Wetland and Uplands testing program conducted by the Waterways Experiment Station (WES). Sediment from the study areas was compared with reference sediment collected at the Bay Farm Island Borrow area (R-BF), the Alcatraz dredged material disposal site (R-AC) and the Alcatraz environs site (R-AM), two offshore sites [Point Reyes coarse (R-PC) and Point Reyes fine (R-PF)] as well as the off-shelf site (R-OS). Toxicology control sediments for test validation were obtained from Sequim Bay, Washington (C-SB); West Beach, Whidbey Island, Washington (C-WB); and Tomales Bay, California (C-NE).

Sediments collected for the Phase III A Project were evaluated through geologic examination, physical and chemical analyses, and a series of toxicity and bioaccumulation tests. Geologic examination included descriptions of the sediment layers and other visually evident aspects of the sediment. Physical and chemical analyses included the following conventional 
sediment parameters: grain size, total organic carbon, total volatile solids, oil and grease, and total petroleum hydrocarbons. Chemical contaminant analyses included pesticides, polychlorinated biphenyls (PCBs), polynuclear aromatic hydrocarbons (PAHs), metals, and butyltins.

Solid-phase (SP) and suspended-particulate-phase (SPP) toxicity tests, and solid-phase bioaccumulation tests were conducted on the sediments according to guidelines in the Draft Implementation Manual. Three species of marine invertebrates and one species of juvenile fish were used for SP tests: 1) the bent-nose clam Macoma nasuta, 2) the marine worm Nephtys caecoides, 3) the amphipod Rhepoxynius abronius, and 4) the sanddab Citharichtys stigmaeus. Contaminants of concern were also measured in the tissues of $M$. nasuta and $N$. caecoides. The sanddab C. stigmaeus, the mysid shrimp Holmesimysis sculpta, and larvae of the oyster Crassostrea gigas w/ere used for SPP tests.

In addition to this section, Section 2.0 presents the materials and methods for sample collection, sample handling and sample processing, geologic observations, biological tests, physical and chemical analyses, and data analysis as well as the quality assurance/quality control (QA/QC) considerations associated with each of these measurements. Results of geologic observations, sediment chemistry, toxicity tests, and bioaccumulation are given in Section 3.0. Section 4.0 provides a discussion of the results and conclusions. References are provided in Section 5.0. Volume 2 of this report contains a series of appendixes presenting the following information:

\section{Volume 2}

$\begin{array}{lll}\text { Appendix A } & - & \text { Field sampling } \\ \text { Appendix B } & - & \text { Geologic analysis } \\ \text { Appendixes C-D } & - & \text { Sediment chemistry } \\ \text { Appendixes E-O } & - & \text { Bioassay results } \\ \text { Appendix P } & - & M . \text { nasuta Tissue Chemistry Data } \\ \text { Appendix Q } & - & \text { N. caecoides Tissue Chemistry Data } \\ \text { Appendix R } & - & \begin{array}{l}\text { Statistical Analysis of M. nasuta } \\ \text { Bioaccumulation } \\ \text { Appendix S }\end{array} \\ & - & \begin{array}{l}\text { Statistical Analysis of } N . \text { caecoides } \\ \text { Bioaccumulatio }\end{array}\end{array}$




\subsection{MATERIALS AND METHODS}

\subsection{SEDIMENT COLLECTION}

The MSL collected four types of sediment samples from 35 stations (Figures 2.1 through 2.4) during June 1990 to achieve the objectives of the Phase III A Project. Because of unacceptably low control survival for the polychaetes in the initial $M$. nasuta/N. caecoides 10-day (86\% survival) and 28-day (5!\% survival) tests, the tests were rerun. During the September 1990 sampling efforts, sediments were collected for Oakland Harbor Phase III 38-Foot and Oakland Harbor Phase III A retest programs. The sediments were retested using $M$. nasuta and $N$. caecoides at the following stations: I-C3, I-C5, I-C7 through I-C12, I-C14 through I-C18, I-S1, I-TI, and I-T3. The control and reference sediments used for the $M$. nasuta/ $N$. caecoides retest were from the same locations as those collected during the Phase III A Project. The Phase III 38-Foot Prr gram was run concurrently with the Phase III A retest. Phase III 38-Foot data are provided in Ward et al. 1992. The results of both the Phase III A and Phase III A retest programs are presented in the following sections. Table 2.1 lists the code identification of the samples collected, the sediment treatments prepared, and the analyses perforned on each sediment treatment.

\subsubsection{Qakland Harbor Sediment Sampling Methods}

Two types of vibratory-hammer core samplers, a 12-in.-dianeter split core and a 4-in.diameter core (Figure 2.5), were used to collect sediment samples from Oaklard Inner and Outer Harbors for the Phase III A Project. Both coring devices were designed by MSL, and Manson Construction and Engineering Company of Richmond, California, to sample highly compacted sediments that could not be penetrated by conventional coring devices.

Manson also supplied the derrick barge Hagar, a push boat, support equipment, and vessel and coring crews for the Phase III A sampling program. The Hagar provided a $150-\mathrm{ft} \times 60-\mathrm{ft}$ work platform and was equipped with a 150-ft boom and crane to support the coring device. Once the barge was in position, 60-ft spud anchors were lowered to maintain that position. Crowley Dock, operated by Crowley Marine, was used as the staging area for all coring operations.

Land and Sea Surveys of Ventura, California, provided navigational support throughout the coring operations. Land and Sea used a Geodometer laser/range azimuth positioning system to locate the coring stations. Navigational survey control points were located at the Union Pacific Railroad Yard (California State Coordinates - Zone III - N478193.85, E1471745.84), Monument Chan (California Coordinates - N474967.18, E1479560.29), and the Crowley Marine Dock in the 


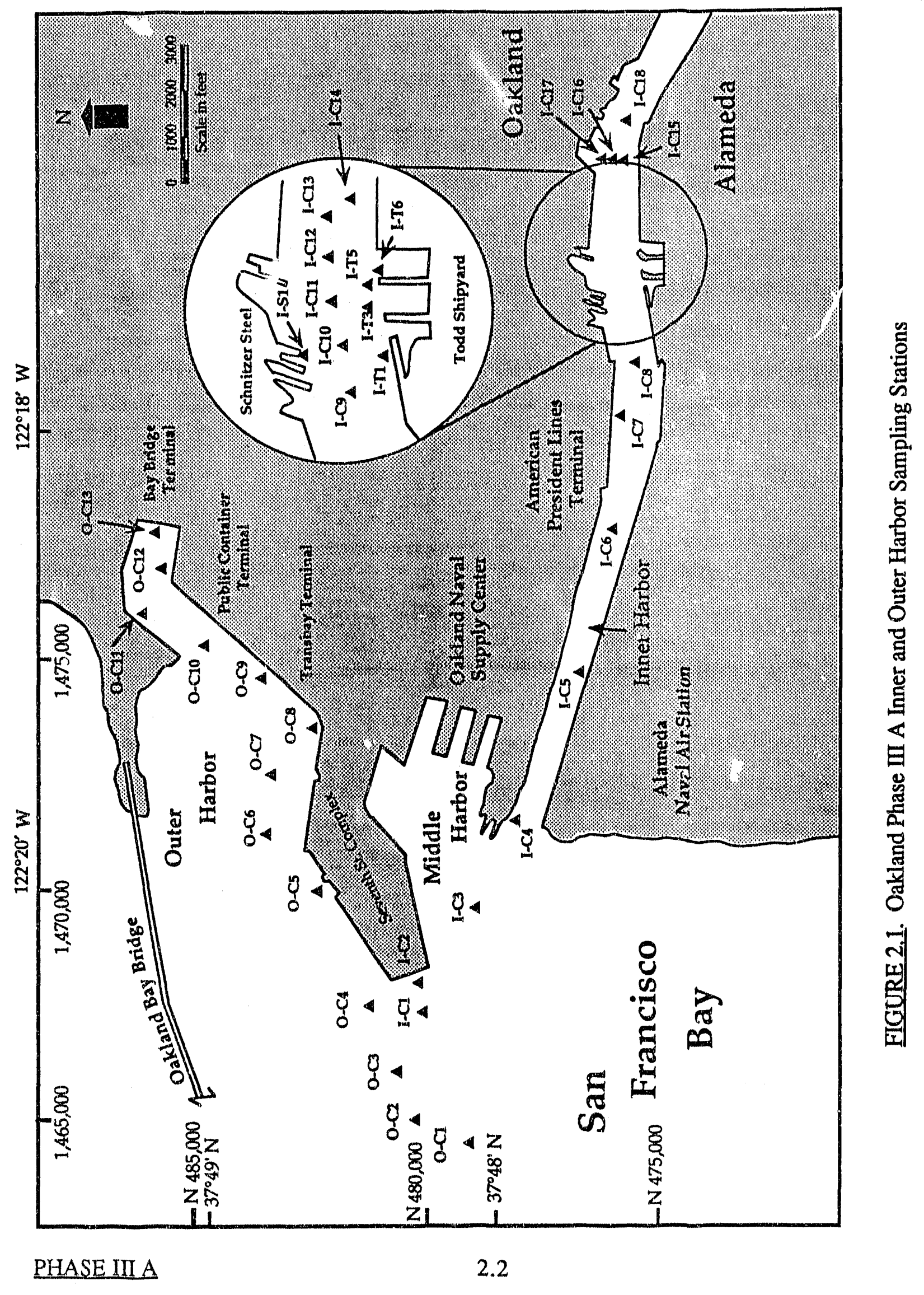




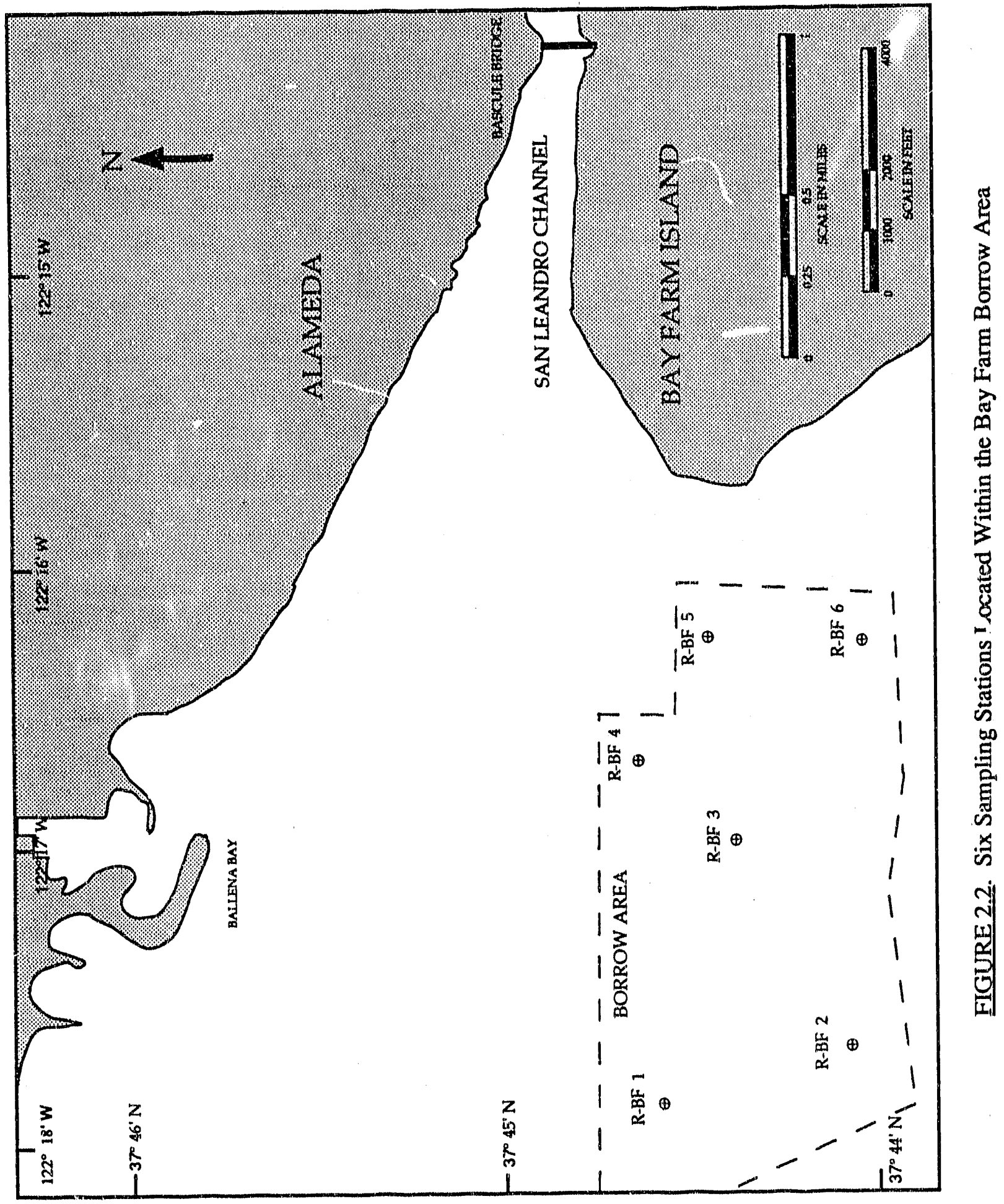

PHASE IIIA

2.3 


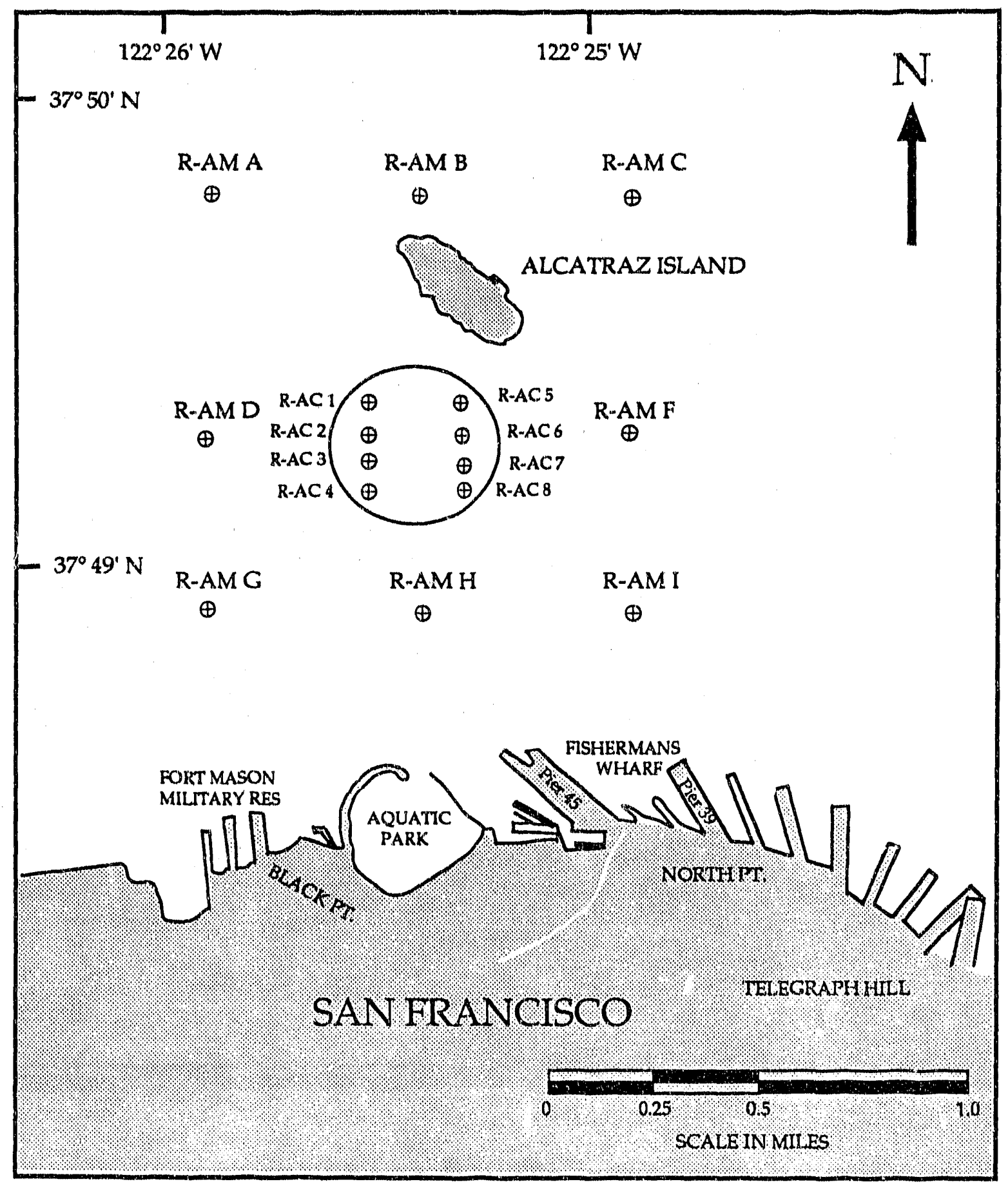

EIGURE 2,3. Sampling Stations R-AM and R-AC (Alcairaz Disposal Site) 


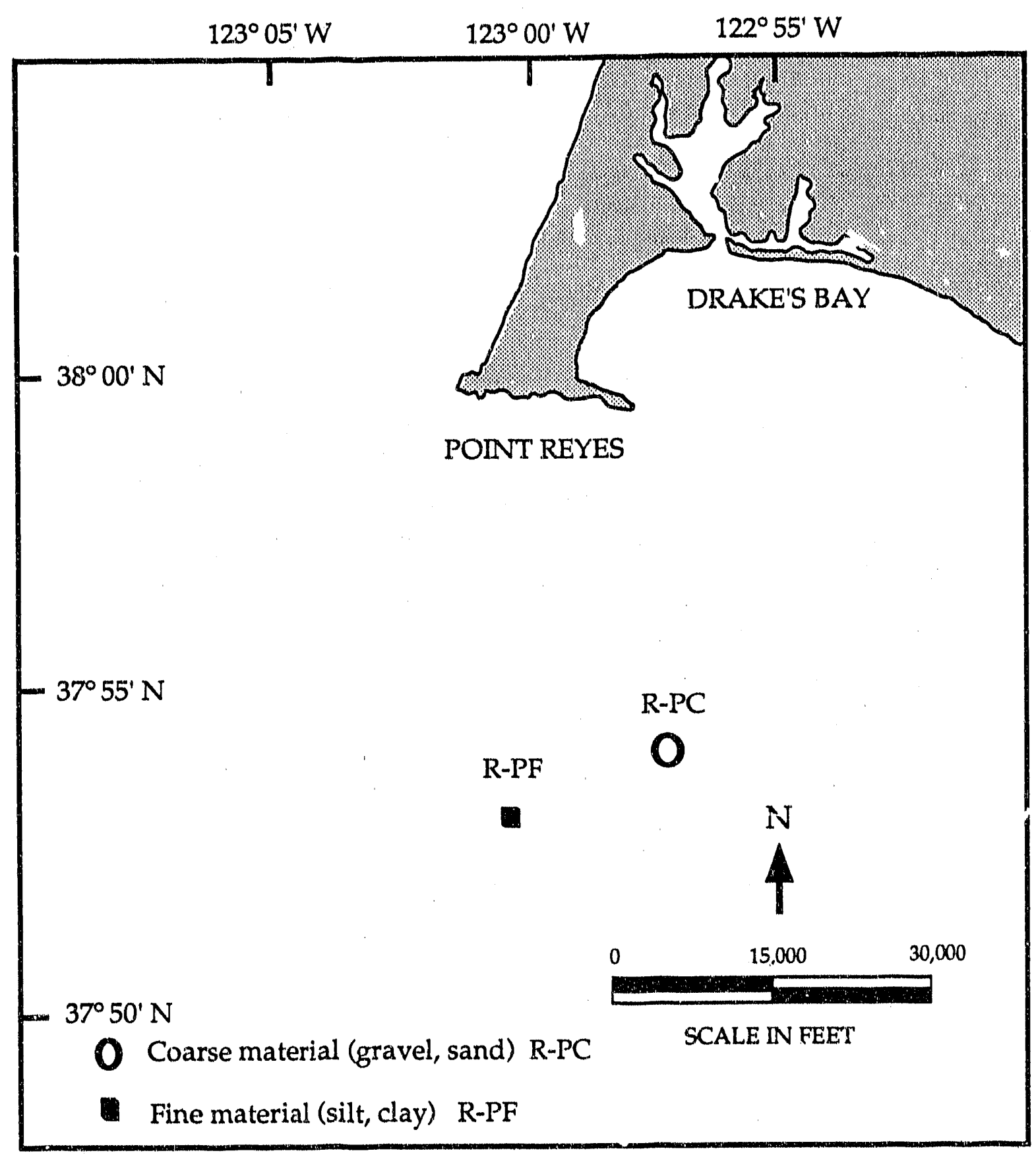

EIGURE 2.4. Location of Offshore Reference Stations 
TABLE 2.1. Sediment Sample Identification Codes and Analyses

Sediment

Treatment

Identification
Sediment

Treatments for Chemical Analysis
Sediment Treatments for Biological Analysis

$\mathrm{SP}^{(\mathrm{a})} \quad \mathrm{SPP}^{(\mathrm{b})} \quad$ WES(c)

Qakland Inner Harbor Stations

\begin{tabular}{|c|c|c|c|c|}
\hline I-C1 & $\ldots$...(d) & ... & .... & $A C-1(0)$ \\
\hline I-C2 & -.. & ... & -.. & $\mathrm{AC}-1$ \\
\hline I-C3 & I-C3 & I-C3 & ... & AC-1 \\
\hline I-C4 & I-C4 & $\mathrm{I}-\mathrm{C} 4$ & -.. & $\mathrm{AC}-1$ \\
\hline I-C5 & I-C5 & I-C5 & $\ldots$ & AC-1 \\
\hline I-C6 & $\ldots$ & $\ldots$ & $\ldots$ & AC-1 \\
\hline I-C7 & I-C7 & I-C7 & $-\cdots$ & $\mathrm{AC}-1$ \\
\hline I-C8 & I-C8 & I-C8 & $\cdots$ & AC-1 \\
\hline I-C9 & I-C9 & $\mathrm{I}-\mathrm{C} 9$ & BC-4 & AC-1 \\
\hline I-C10 & I-C10 & $\mathrm{I}-\mathrm{C} 10$ & BC-4 & AC-1 \\
\hline $\mathrm{I}-\mathrm{C} 11$ & $\mathrm{I}-\mathrm{Cl} 1$ & $\mathrm{I}-\mathrm{C} 11$ & BC- 4 & $A C-1$ \\
\hline $\mathrm{I}-\mathrm{C} 12$ & $1-\mathrm{Cl} 2$ & $\mathrm{I}-\mathrm{C} 12$ & BC- 4 & $\mathrm{AC}-1$ \\
\hline I-C13 & $\ldots$ & $\cdots$ & $\cdots$ & $\mathrm{AC}-1$ \\
\hline I-C14 & $\mathrm{I}-\mathrm{C} 14$ & I-C14 & BC-3 & $A C-1$ \\
\hline I-C 15 & I-C15 & I-C15 & BC-3 & AC- 1 \\
\hline $\mathrm{I}-\mathrm{C} 16$ & I-C16 & I-C16 & BC- 3 & $\mathrm{AC}-1$ \\
\hline $\mathrm{I}-\mathrm{C} 17$ & $\mathrm{I}-\mathrm{C} 17$ & $\mathrm{I}-\mathrm{C} 17$ & BC- 3 & AC-1 \\
\hline I-C18 & $\mathrm{I}-\mathrm{C} 18$ & I-C 18 & $\mathrm{BC}-3$ & $\mathrm{AC}-1$ \\
\hline I-S 1 & I-S 1 & I-S1 & $\ldots$ & ... \\
\hline I.T1 & $\mathrm{I}-\mathrm{T} 1$ & I-T1 & -.. & $\ldots$ \\
\hline I-T3 & I-T3 & I-T3 & ... & $\ldots$ \\
\hline I-T5 & $\mathrm{I}-\mathrm{T} 5$ & I-T5 & -.. & $\cdots$ \\
\hline
\end{tabular}

Qakland Quter Harbor Stations

$\mathrm{O}-\mathrm{C} 1$ through O-C13

(a) Solid-phase toxicity test.

(b) Suspended-particulate-phace toxicity test.

(c) Waterways Experimental Station evaluation.

(d) Sediment trearment not used for this analysis at the direction of USACE.

(e) This composite station received chemical and grain size analysis and solid-phase toxicity testing. 


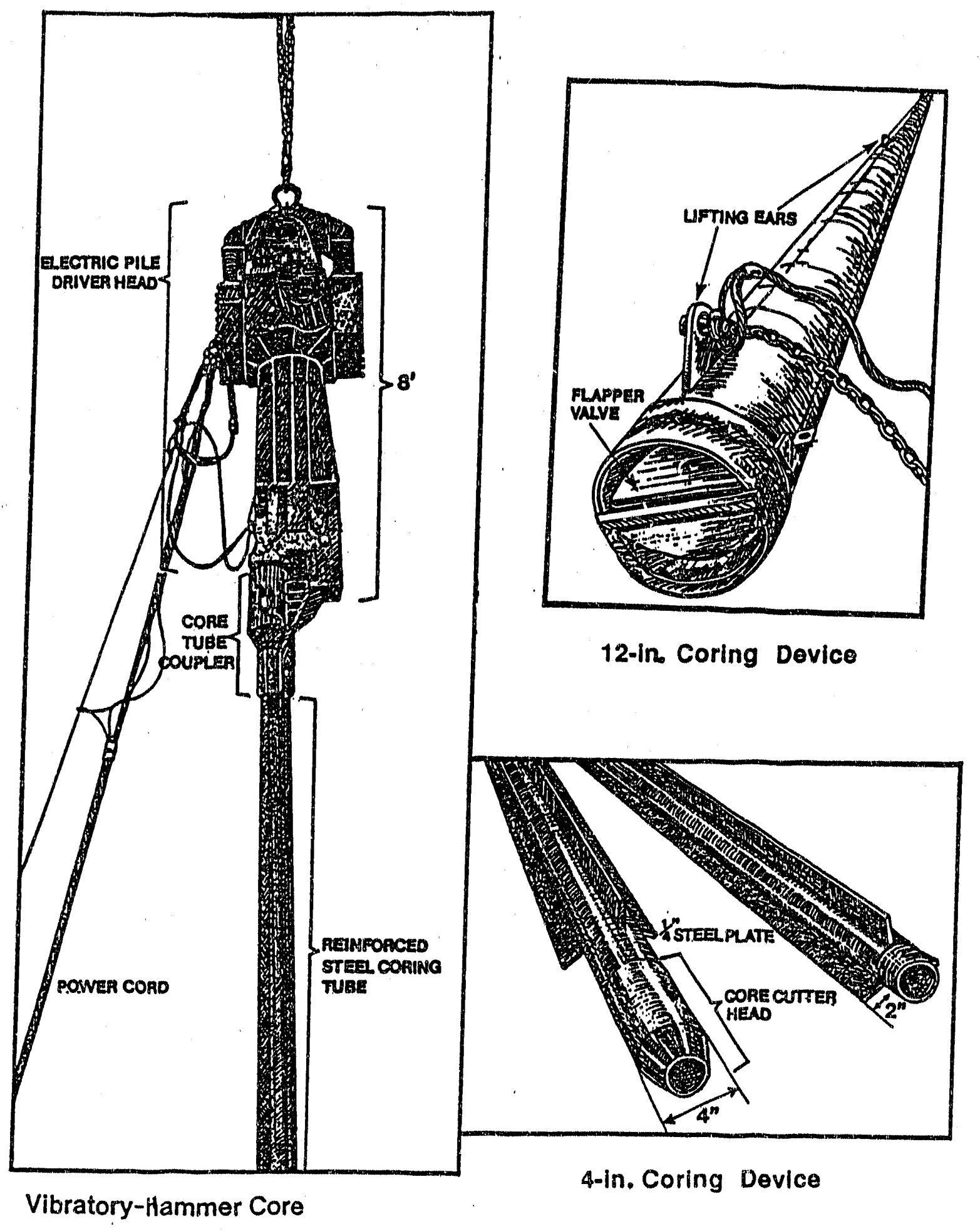

EIGURE 2.5. Components of the 4-in. and 12-in. Vibratory-Hammer Coring Devices 
vicinity of Todd Shipyard (California Coordinates - N475303.82, E1483103.14). An additional point was used to site the maneuvering area (N475348.26, E1483606.00).

Prior to coring, navigators surveyed the station reference coordinates, deployed station buoys, and determined station water depths with a calibrated fathometer. The uncornected depth, determined with the fathometer, was recorded in station logs kept by Land and Sea Surveys. Depth corrections were made during the coring operation by measuring water level with respect to a known tidal benchmark (e.g., Monument Chan is $10.39 \mathrm{ft}$ above MLCW) and applying the appropriate correction factor to the depth measured from the coring barge at that time. By eliminating the use of a tide table, errors resulting from tide table corrections were reduced. However, to check corrected MLLW depths provided to the derrick barge by Land and Sea Surveys personnel, tide tables were compared to MLLW water depths in the coring area during coring operations. Uncorrected water depths and verified MLLW depths vere recorded in MSL field logs. Water depth information was used to calculate the total core length required to penetrate the substrate to the project depth of $-42 \mathrm{ft}$ (plus $2 \mathrm{ft}$ overdepth).

After the Hagar was positioned and the MLLW depths verified, the station buoy offset was determined to permit the coring device to be positioned correctly. To collect a sample, the core sampler was suspended from the crane on the derrick barge, and the crane was used to lower the sampler to the sediment. As the coring device was lowered to the seafloor, the coring depth was measured using the calibration marks on the core barrel. If the weight of the sampler itself did not cause it to penetrate the sediment to $-44 \mathrm{ft}$ MLLW (project depth of $-42 \mathrm{ft}$ MLLW plus $2 \mathrm{ft}$ overdepth), the core sampler was driven to depth by a 6 -ton, Westam electric vibratory hammer. The core barrel was then lifted from the sediment by the crane, decoupled from the vibratory hammer, and lowered onto the deck of the barge.

The 4-in.-diameter sampler was used to collect cores from the Oakland Harbor sites for geological description, chemical analysis, and toxicological testing. The 4-in. core barrel was lined with a length of steam-cleaned Lexan polycarbonate tubing that protected the sediment from disturbance and contamination during sampling. Sediment was retained in the Lexan core liner either by specially designed core catchers or a flapper valve (Figure 2.5 ). When the sampler was brought onto the barge, the Lexan liner containing the sediment was pulled from the sampler and measured to confirm that sufficient depth was reached. The core was then capped at both ends and labeled. If necessary, samples were cut and capped in shorter sections to fit inside the storage freezer on board the D/B Hagar, where all core samples were stored at approximately $4^{\circ} \mathrm{C}$. Sediment compesite sites AC-1 and AC- 3 were consolidated by mixing sediment from the 4 -in. 
cores in large cement mixers at the MSL. These composite stations received chemical and grain size analysis and solid-phase toxicity testing.

Many of the Phase III A samples were collected using a sampler w th two 4-in.-diameter core barrels. The obvious advantage of the double-barreled sampler is that it permits collection of duplicate core samples simultaneously. However, the double-barreled core sampler operates optimally only when both core barrels enter the sediment at exactly the same angle. Penetration of the double core through the sedirnent when the barrels are slightly bent was much slower than it was for the single core.

The 12-in. split-core sampler yields approximately $5.8 \mathrm{gal}$ of sediment per running foot, so it was used to collect the large volumes of sediment needed for the WES uplands/wetlands and FATES testing programs. The 12-in. sampler was split longitudinally for approximately $30 \mathrm{ft}$, with the two halves connected by hinged "doors," each approximately $10 \mathrm{ft}$ long. The upper door was welded shut most of the time, but was cut open when a longer core was needed. The lower door was held shut by chain binders during sampling. Sediment was retained in the 12-in. split core either by the strength of the compact sediment at the bottom or by a specially designed flapper valve. When a 12-in. core was brought on deck, the lower door was unchained and pried open to expose the sediment. The length of the core was measured and recorded. If sufficient sediment was collected, the sediment from the appropriate depth fraction (mudline to $-44 \mathrm{ft}$ MLLW) was shoveled into a labeled, epoxy-coated 55-gal drum. The drums were kept covered at all times unless actively being filled. The core sampler was thoroughly rinsed with seawater between samples. Processing of WES sediment samples took place on board the Hagar. Sediment from the 12-in. cores was collected and composited to make stations AC-1 (Oakland Inner Harbor) and AC-3 (Oakland Outer Harbor). These composite stations received chemical and grain size analysis and solid-phase toxicity testing. Sediment from the 12-in. cores was also sent to WES and composited into station AC-1 for their testing. A subsample of these composites was sent to the MSL at the end of the Phase III A testing. This sample was tested in August 1990 with several others that were collected from San Francisco Bay for WES.

Sampling took place at Oakland Inner and Outer Harbors from June 4 through 13, 1990. A total of 128 acceptable cores were collected at 35 stations, as shown in Figure 2.1. Mudline depths (as evidenced by the ring of mud surrounding the core barrel) at the sampling locations varied from $-25.4 \mathrm{ft}$ MLLW (Station T-5) to -41.5 ft MLLW (Station OC-2), resulting in core lengths of $18.6 \mathrm{ft}$ and $2.5 \mathrm{ft}$, respectively. The minimum sediment volume required for each sediment treatment $(60 \mathrm{~L})$ was obtained with $28.0 \mathrm{ft}$ of core from the 4-in.-diameter core. All stations were 
successfully cored to the project depth. Field data for coring operations are summarized in Volume 2, Appendix A.

\subsubsection{Reference and Control Sediment Collection}

The F/V Cobra was used for collection of the San Francisco Bay, offshore, and off-shelf reference sediments. Disposal site reference sediment was collected with a $0.1-\mathrm{m}^{2}$ modified van Veen grab sampler from three areas within San Francisco Bay. A summary of the sampling data is provided in Volume 2, Appendix A. Six sampling stations (designated R-BF 1 through R-BF 6) were located within the Bay Farm Borrow Area (Figure 2.2). Eight stations (designated R-AC 1 through R-AC 8) were located within a circle having a diameter of approximately $0.3 \mathrm{nmi}$, whose center is located $0.25 \mathrm{nmi}$ south of Alcatraz Island. This circle is the Alcatraz Island Dredged Sediment Disposal Site (Figure 2.3). Nine stations (designated R-AM A through R-AM I) were located on a grid surrounding Alcatraz Island at locations presumably not affected by the disposal of dredged material (Figure 2.3). Sampling stations were located by using a combination of LORAN $\mathrm{C}$ and variable fix and range radar, as well as fixes to identifiable shore ranges. Sediment from the grab samples was placed into coolers and stored at $4^{\circ} \mathrm{C}$ until transferred to the refrigerated truck and transported to the MSL for chemical analysis and bioassay testing. Sediment from all stations within an area was sieved through a $0.5-\mathrm{mm}$ screen and composited before use.

Two types of offshore reference sediments were collected from an area south of Point Reyes, California (Figure 2.4), and one farther offshore (Figure 1.1). Six samples were collected with a large pipe dredge from an area of silty sediment (fine reference) and composited (designated R-PF). Nine samples were collected from an area of sandy material (coarse reference) and composited (designated R-PC). The off-shelf dredge sample (designated R-OS) was taken at a depth of about $4200 \mathrm{ft}$ from an area approximately $40 \mathrm{nmi}$ west of Half-Moon Bay, California.

Native control sediments were collected from three areas: Sequim Bay, Washington (designated C-SB); West Beach on Whidbey Island, Washington (designated C-WB); and Tomales Bay, California (designated C-NE). About $156 \mathrm{~L}$ of native sediment for $M$. nasuta were collected from Sequim Bay (Figure 2.6) using a modified van Veen grab sampler. A small dredge was used to collect approximately $50 \mathrm{~L}$ of native sediment for $R$. abronius from West Beach (Figure 2.7) in waters about $15 \mathrm{ft}$ deep. Sequim Bay and West Beach sediments were placed into coolers and transported to MSL on the day of collection. Native sediments for $N$. caecoides were collected from Tomales Bay $\left(38^{\circ} 13.83^{\prime} \mathrm{N}, 122^{\circ} 57.67^{\prime} \mathrm{W}\right)$ (Figure 2.8), placed in coolers, and transported overnight to MSL. Each native sediment was washed through a sieve with mesh openings of $0.5-\mathrm{mm}$ to remove larger predatory animals and debris. Additionally, the Tomales Bay sediment 


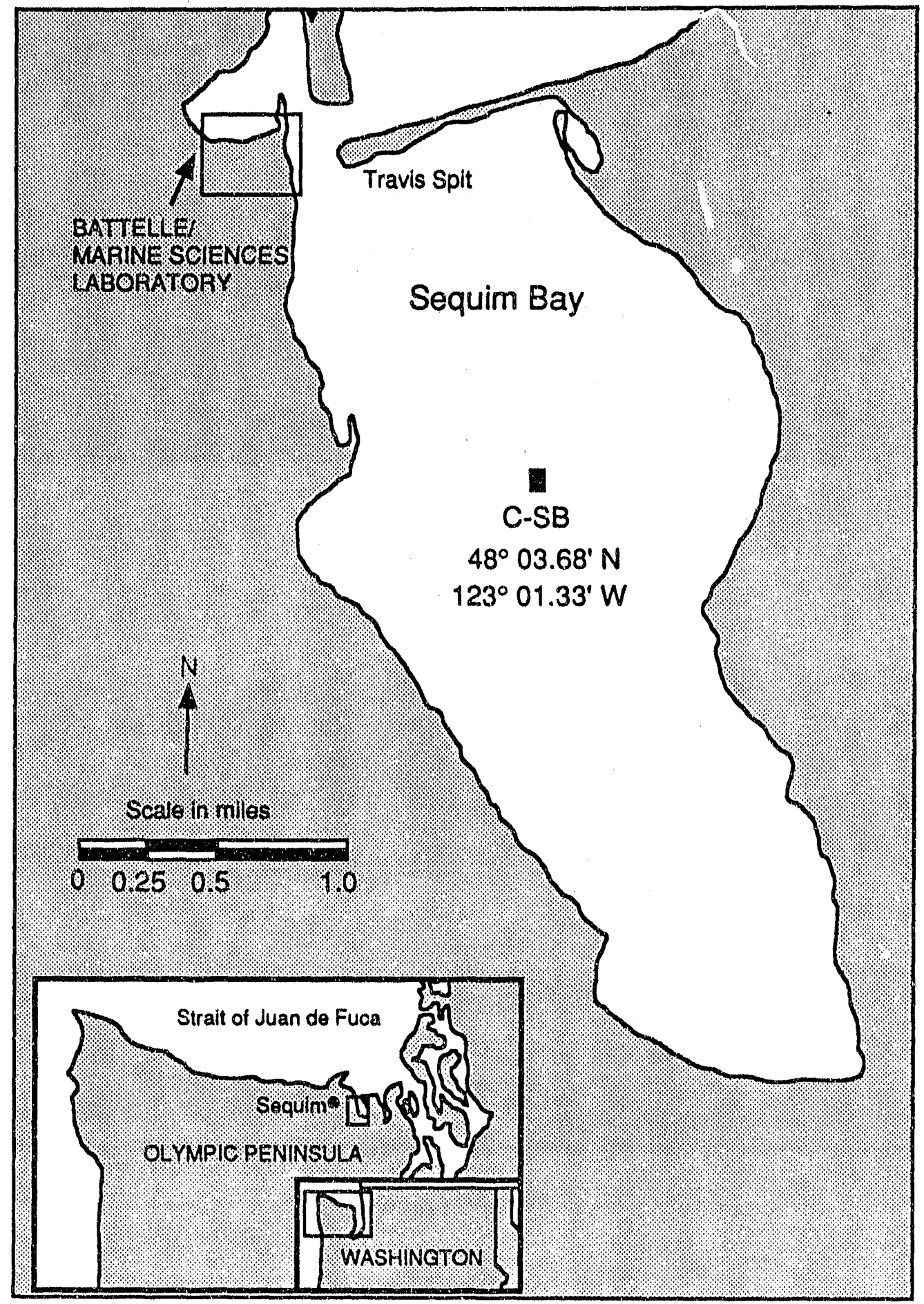

EIGURE 2.6. Location of Sequim Bay, Washington, Control Station (C-SB) 


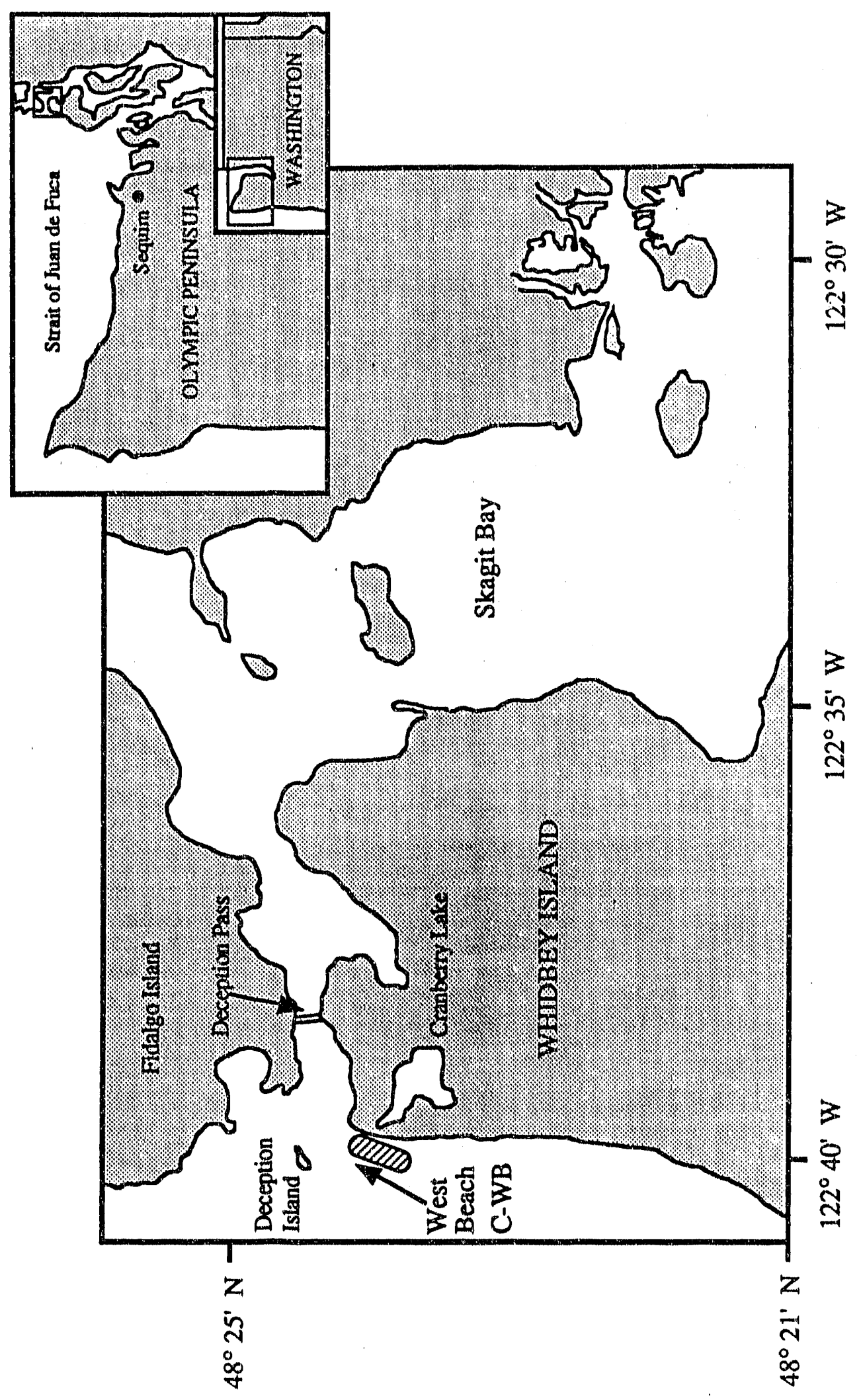

年 


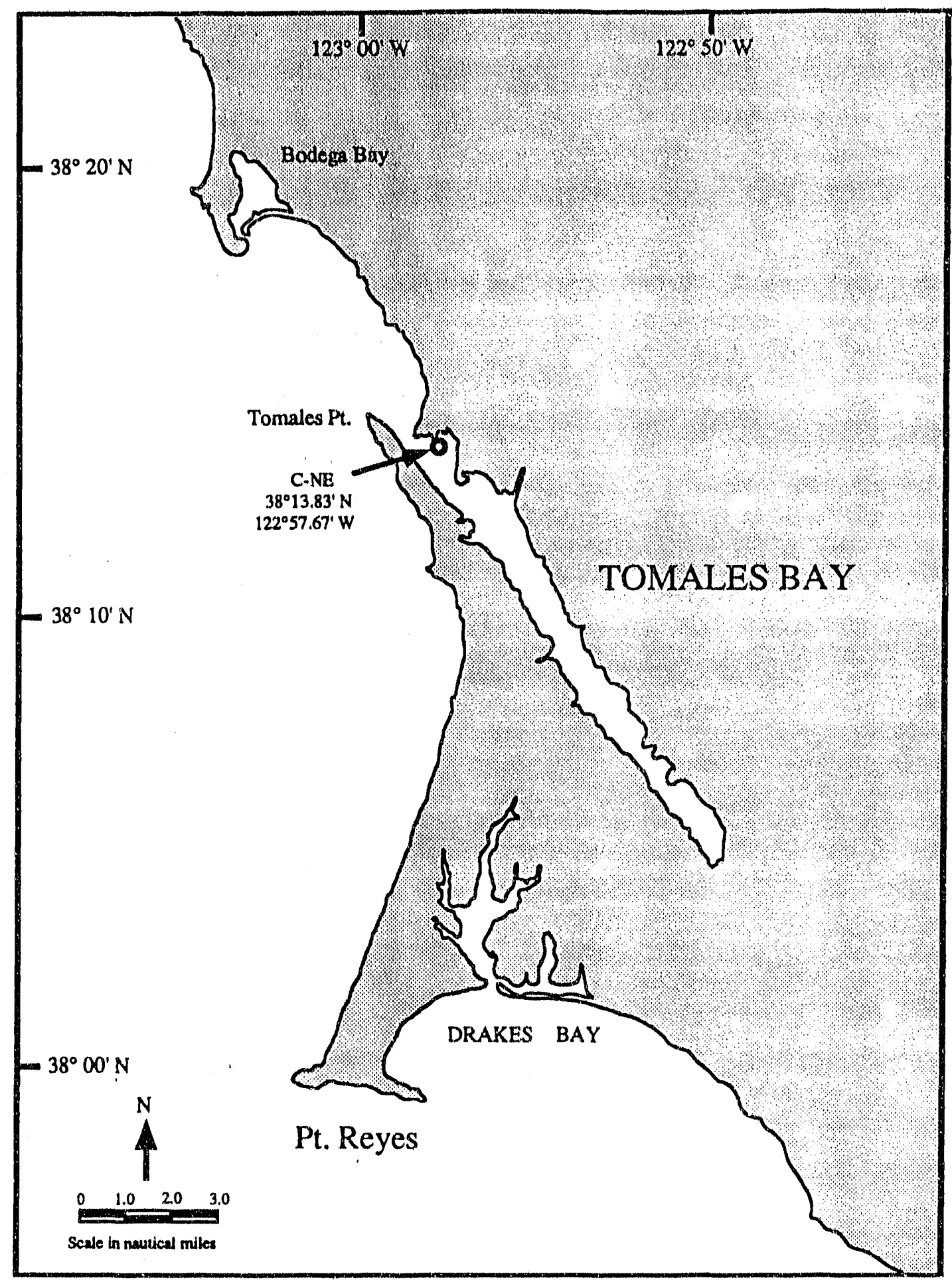

EIGURE 2.8. Location of Tomales Bay, California, Control Station (C-NE) 
was vigorously aerated in a flow-through tank prior to use in testing to aerate the organically rich sediment.

\subsubsection{Sample Shipment}

The test sediment samples collected in Oakland Inner Harbor were held in 4-in. core tubes. The reference and control sediments were contained in coolers. Each day after the samples were collected they were off-loaded into a refrigerated van and stored at $4^{\circ} \mathrm{C}$. Chain-of-custody forms were completed in the field, sealed in plastic bags, and attached to one of the coolers. When all sampling was completed, samples for WES were shipped to Vicksburg, Mississippi, in one refrigerated van maintained at $4^{\circ} \mathrm{C}$. Samples for the MSL were shipped to Sequim, Washington, in another refrigerated van maintained at $4^{\circ} \mathrm{C}$. Once at the MSL, samples were held at $4^{\circ} \mathrm{C}$ until used for chemistry or bioassay testing. Upon receipt the samples were inventoried against chain-ofcustody forms and maintained in the refrigerated van. All samples were used within their 2-week holding limit.

\subsection{TEST ORGANISM COLLECTUON}

Six different species of marine organisms were used for the Oakland Phase III A sediment evaluations:

- Bent-nose clam (Macoma nasuta)

- Marine worm (Nephtys caecoides)

- Marine amphipod (Rhepoxynius abronius)

- Sanddab (Citharicthys stigmaeus)

- Mysid shrimp (Holmesimysis sculpta)

- Oyster larvae (Crassostrea gigas)

These animals were obtained before and during sediment collection operations.

\subsubsection{M.nasuta Collection}

Approximately 10,000 individuals of the bent-nose clam, $M$. nasuta, were collected in Discovery Bay, Washington, $\left(48^{\circ} 02.80^{\prime} \mathrm{N}, 122^{\circ} 50.00^{\prime} \mathrm{W}\right)$ by Johnson and Gunstone Clams of Port Townsend, Washington. Discovery Bay is located near the MSL, and is considered an uncontaminated habitat for $M$. nasuta (EPA 1986a). Clams were collected with a shovel, sieve, and bucket. Care was taken to minimize shell breakage. In the field, clams were kept cool in large 
tubs containing sediment and seawater from the collection site. The clams were transported to the MSL on the day of collection and placed in large flow-through tanks containing clean sediment from Sequim Bay, Washington. Clams were maintained in the flow-through tanks at ambient Sequim Bay temperature and salinity (approximately $15^{\circ} \mathrm{C}, 32 \%$ ) until testing began.

\subsubsection{N.caecoides Collection}

Brezina \& Associates of Dillon Beach, California, collected about 9800 individuals of $N$. caecoides from mud flats in Tomales Bay, California. These marine worms were collected with a shovel, bucket, and sieve. Worms were placed into clean coolers containing sediment and seawater from the collection site. Care was taken to avoid damage to the worms during collection and shipment. Prior to shipment to MSL, the seawater in each cooler was supersaturated with oxygen (22 ppm). Upon arrival, the polychaetes were placed in large flow-through tanks containing sediment from the collection site and maintained at ambient Sequim Bay temperature and salinity until the initiation of testing.

\subsubsection{R. abronius Collection}

A Battelle-designed sediment dredge was used to collect approximately 12,000 individuals of the amphipod R. abronius from a depth of $15 \mathrm{ft}$ near West Beach, Whidbey Island, Washington. Amphipods were transferred from the dredge to coolers containing sediment and seawater from the collection area. On the day of collection, the animals were transported to MSL where they were maintained in flow-through tanks containing native sediment. Water in the tanks was kept at ambient Sequim Bay salinity and maintained at $15^{\circ} \mathrm{C}$.

\subsubsection{C.stigmaeus Collection}

Brezina \& Associates collected approximately 2300 juvenile sanddabs, C. stigmaeus, from 12 to $15 \mathrm{ft}$ of water near the mouth of Tomales Bay, California. Sanddabs were captured with a small trawl with a 0.25 -in. mesh and no cod end. The trawl was held close to the work boat so a dip net could be used to transfer the fish from the sawl to the holding container. The fish were placed in oxygen-saturated seawater in double-lined plastic bags and delivered overnight to the MSL. Upon receipt at MSL, the fish were gradually acclimated to Sequim Bay seawater and placed in large flow-through tanks with a sediment substrate. The sanddabs were fed freeze-dried krill twice daily and kept at ambient Sequim Bay salinity and a temperature of $15^{\circ} \mathrm{C}$ until testing began. 


\subsubsection{H. sculpta Collection}

Brezina \& Associates also collected approximately 1200 mysid shrimp, H. sculpta, off Pt. Lobos, the southernmost point of Monterey, California. Mysids were captured with small dip nets and transferred to containers on the work boat. Mysids were placed in oxygen-saturated water in double-lined plastic bags and delivered overnight to MSL. Upon receipt at MSL, the mysids were gradually acclimated to Sequim Bay seawater. Mysids were maintained in flow-through tanks at ambient Sequim Bay salinity and a temperature of $15^{\circ} \mathrm{C}$ until toxicity testing began. During the holding period the mysids were fed brine shrimp nauplii.

\subsubsection{C.gigas Collection}

Eighteen conditioned, adult oysters, C. gigas, were obtained from Coast Oyster Company of Quilcene, Washington, to serve as brood stock. The adults were held in static tanks at $15^{\circ} \mathrm{C}$ for up to $24 \mathrm{~h}$ or until the initiation of testing. Larvae to be used in the toxicity testing were obtained by thermostimulation of the brood stock.

\subsection{SAMPLE PREPARATIONPROCEDURES}

\subsubsection{Laboratory Glassware and Equipment Preparation}

All stainless-steel labware, such as the bowls for compositing sediments, were washed with warm, soapy water, rinsed five times with deionized water, and allowed to air dry. They were then rinsed with methylene chloride under a fume hood and the methylene chloride was allowed to evaporate under the hood.

Glassware, titanium tools, PVC, and Nalgene were also washed with warm soapy water, rinsed five times with deionized water, and allowed to air dry. Once dry, labware was soaked in a $5 \%$ reagent grade nitric acid bath for a minimum of $4 \mathrm{~h}$. After soaking, glassware was rinsed with deionized water five times, and packed in original containers until ready for use.

Rubber stoppers and other porous materials were washed with warm, soapy water, rinsed five times with deionized water, and seasoned with flowing seawater. Seasoning is performed by placing rubber objects in a clean containment device and allowing $0.45-\mu \mathrm{m}$ filtered seawater to flow continuously over the objects for at least 2 days prior to use.

\subsubsection{Preparation of Samples for Solid-Phase Tests}

Solid-phase sample preparation involved two separate processes: 1) preparing the test sediments from 4-in. core samples and 2) preparing the reference and control sediments. 
Approximately $60 \mathrm{~L}$ of sediment was prepared to conduct chernical analyses, solid-phase toxicity and bioaccumulation tests on each test or control sediment.

For the 4-in. core samples, the core tube sections were placed on an epoxy-coated cutting table. The caps were removed from the core liner and the liner was cut longitudinally on opposite sides using a circular-saw and a linoleum knife. The core was then split into two equal halves and placed on a clean epoxy-coated board for observation and analysis.

Any visible shavings of the core liner produced during the cutting process were removed before beginning the geologic description. The geologist then described the core from top to bottom, recording observations such as sediment coarseness or color on core log sheets. Photographs of at least one entire core from each test station were taken by the USACE. In addition, subsamples for analysis of total petroleum hydrocarbons were taken from selected locations to evaluate potential localized contamination of sediment sections. The locations of these subsamples were recorded on core log sheets.

Next, the cores were measured, the sediment extracted, and the desired test sediments were placed in either a clean, labeled, stainless-steel mixing bowl or a clean, epoxy-coated cement mixer for compositing of the test sediment. In some cases, all of the cores from one sampling station were composited; in other cases, cores collected at different sampling stations were composited.

Sediment from the 12-in. cores was collected and composited to form station AC- 1 by USACE WES and shipped to MSL for bioaccumulation testing. Sediment composites AC-1 and AC-3 used in toxicity and bioaccumulation testing at the MSL, were prepared while sampling in Oakland Inner Harbor. Subsamples from the -38 to $-44 \mathrm{ft}$ MLLW section of each 12 -in. core collected in Oakland Inner Harbor were combined in epoxy-coated mixers to produce composite sample AC-1. Sediment sections from the core's surface to $-44 \mathrm{ft}$ MLLW from each 12-in. core collected in Oakland Outer Harbor were combined in epoxy-coated mixers to produce composite sample AC-3. Upon receipt, these field composites were not thoroughly mixed; therefore, they were put into the mixer to achieve a homogenous consistency. Approximately $60 \mathrm{~L}$ of test sediment was needed for solid-phase testing.

Compositing procedures varied according to sediment type. Dense or cohesive sediments were grated into smaller pieces with a stainless-steel cheese grater. The grated sediment was then mixed using either stainless-steel spoons or a cement mixer. Unconsolidated and noncohesive sediments were mixed with spoons in stainless-steel bowls. Sediment samples were mixed until uniform consistency and color were visible throughout the sediment in the bowl or mixer. Minimal amounts of $0.45-\mu \mathrm{m}$ filtered seawater were added as needed to achieve a homogeneous

PHASE III A 
consistency. After compositing, sample aliquots for chemical analyses were removed and either frozen, dried, or refrigerated, as appropriate, for the particular type of chemical analysis. All test sediments were either used immediately after compositing, or covered with Teflon and stored at $4^{\circ} \mathrm{C}$ until testing. Excess sediment was placed in labeled, 5-gai buckets, held until chemical testing was completed, and appropriately disposed. To avoid contamination between stations, stainlesssteel items were washed with warm, soapy water and rinsed with methylene chloride. The epoxycoated cement mixer was also washed and rinsed with deionized water.

Reference and control sediments were stored in an ice chest at $4^{\circ} \mathrm{C}$ until sieved. Reference and control sediments were sieved using stacked screens having mesh diameters of 0.5 and $1.0 \mathrm{~mm}$. The sieving stand was designed so that sieved sediments were collected in a $55 \mathrm{mgal}$, acidwashed aquarium (one for each reference or control treatment) containing approximately $15 \mathrm{gal}$ of filtered seawater. A Simms Geyser submersible water pump was placed in the aquarium to recirculate the water used for sieving. Organisms collected on the sieves were discardu 1 , and the small amount of debris remaining on the screen was addled to the sieved sediment. Approximately $100 \mathrm{gal}$ of sediment was prepared for each reference or control treatment and allowed to settle in the aquaria overnight at $4^{\circ} \mathrm{C}$. After settling, the supernatant water was siphoned off each aquarium and discarded, and the sediment was transferred to the clean cement mixer for compositing. The sediment was mixed for 5 to 10 min or until a homogenous mixture was formed. At the end of the mixing period, each reference or control sample was again transferred from the mixer to its $55-\mathrm{gal}$ aquarium and stored at $4^{\circ} \mathrm{C}$ until needed for testing. Between sieving of each reference sample, all equipment was thoroughly rinsed with $0.45-\mu \mathrm{m}$ filtered seawater to avoid cross-contamination of samples.

\subsubsection{Preparation of Samples for Suspended-Particulate-Phase Tests}

The SPP is the liquid supernatant that remains after mixing sediment with seawater and allowing heavier particles to settle out. Because the sample preparation does not involve filtration, this phase contains suspended particles as well as dissolved constituents. The SPP tests evaluate effects caused by both the physical presence of the suspended particles and the chemical toxicity of contaminants associated with the particles or dissolved fractions. The process is intended to approximate exposure conditions created as a result of materials being discharged through the water column during dredge-disposal operations.

Approximately $56 \mathrm{~L}$ of each test treatment was needed for SPP testing. Each SPP treatment was a 4:1 (volume:volume) water to sediment mixture. Two sets of clean, 1-L mason jars fitted with Teflon-lined lids were made available for each SPP treatment. Each jar was marked

PHASELIIA $\quad 2.18$ 
at volumes of 200,400 , and $1000 \mathrm{~mL}$. For each SPP treatment, $200 \mathrm{~mL}$ of $0.45-\mu \mathrm{m}$ filtered seawater was placed in the 1-L mason jar. Composited sediment was then added to the jar until it displaced the water to the $400-\mathrm{mL}$ mark. The jar was then filled to the $1000-\mathrm{mL}$ mark with filtered seawater and capped tightly with the Teflon-lined lid. The jar was placed on a shaker table for $30 \mathrm{~min}$, at a shaking rate of 120 to 150 cycles/min. After shaking, the overlying supernatant was poured into 500-mL Teflon containers fitted with Teflon lids. The containers were then placed in a centrifuge and spun for 10 to $15 \mathrm{~min}$ at approximately $1750 \mathrm{rpm}$. Centrifugation was necessary to ensure that the mysid shrimp and speckled sanddabs would be visible when added to the SPP water. After centrifugation, the supernatant was poured into a clean 10-gal aquarium and stored at $4^{\circ} \mathrm{C}$ until used in the SPP tests. The Teflon jars were rinsed after each use and the above procedure was repeated until an adequate arnount of SPP treatment was produced. Between SPP preparations, all glass and Teflon containers were appropriately cleaned according to procedures described in Section 2.3.1.

\subsection{SEDIMENT AND TISSUE CHEMISTRY PROCEDURES}

Sediment samples were analyzed for conventional sediment measurements (i.e., grain size, oil and grease). Chemical analyses were conducted on sediment samples for selected metals, chlorinated pesticides and PCBs, semivolatile organic compounds and butyltins. Table 2.2 lists the parameters for which the Oakland Phase III A scdiment samples were analyzed, as well as analytical goals for detection limits, range of recovery, and relative precision.

Tissue samples were analyzed for selected metals, high and low molecular weight PAHs, PCBs, chlorinated pesticides, and butyltins. Table 2.3 lists the parameters for which the Oakland Phase III A tissue samples were analyzed, as well as analytical goals for detection limits, range of recovery, and relative precision.

The following sections briefly describe the meihods used for analysis of sediments for the required physical and chemical parameters. Analyses followed established EPA procedures where applicable. References are given for all procedures. Quality control samples included analytical triplicates, matrix spike (MS) and matrix spike duplicate (MSD) analyses, surrogates, method blanks and Standard Reference Materials (SRMs). Quality control data are provided in Volume 2.

\subsubsection{Cenventional Sediment Measurements}

Conventional sediment measurements include grain size, total organic carbon (TOC), oil and grease and total petroleum hydrocarbons (TPH), total volatile solids (TVS), and percent solids. Procedures related to these measurements are discussed in the following paragraphs. 
TABLE 22. Analytical Chemistry Requirements for Oakland Harbor Sediment Samples

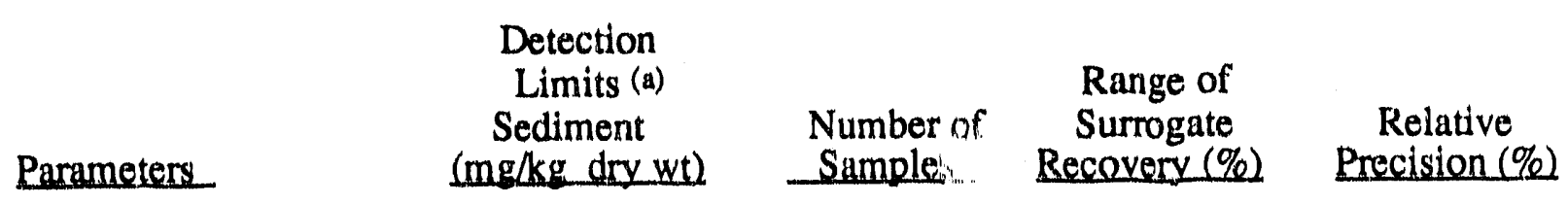

Sediment

Conventionals.

TOC

Oil and Grease

TPH

Grain Size

Total Solids

Metals

$0.1 \%$
20
20
NA(c)
NA

1.0

1.0

0.1

1.0

1.0

0.02

1.0

1.0

0.1

1.0
28

28

28

28

28

$\begin{array}{cc}\ldots(\text { b) } & 10 \\ \cdots- & 10 \\ \cdots & 15 \\ \mathrm{NA} & \cdots \\ \cdots & -\end{array}$

10

15

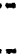

Organic

compounds

Butyltins

PCBs (d)

PAHs(e)

Pesticides(f)
0.01

0.02

0.02

0.002

\section{8 \\ 28 \\ 28 \\ 28 \\ 28 \\ 28 \\ 28 \\ 28 \\ 28 \\ 28}

15

15

15

15

15

15

15

15

15

15

(a) Target detection limits; all efforts were made to reach lowest practical detection limits.

(b) Not available.

(c) Not applicable.

(d) Reported as Aroclor equivalents 1242, 1248, 1254, and 1260 and total PCB. Analyzed using EPA Method 8080.

(e) All compounds on EPA Method 610 list. Analyzed using Method 8270 in S.I.M. mode.

(f) All compounds on EPA Method 608 list. Analyzed using Method 8080. 
TABLE 23. Analydical Chemistry Requirements for Oakland Harbor Tissue Samples

\begin{tabular}{|c|c|c|c|c|}
\hline Parameters & $\begin{array}{c}\text { Detection } \\
\text { Limits (4) } \\
\text { Sediment } \\
\text { (mg/kg dry wt) }\end{array}$ & $\begin{array}{c}\text { Number of } \\
\text { Samples }\end{array}$ & $\begin{array}{c}\text { Range of } \\
\text { Surrogate } \\
\text { Recovery (\%) }\end{array}$ & $\begin{array}{r}\text { Relat } \\
\text { Precision }\end{array}$ \\
\hline \multicolumn{5}{|l|}{ Metals } \\
\hline $\begin{array}{l}\mathrm{Ag} \\
\mathrm{As} \\
\mathrm{Cd} \\
\mathrm{Cr} \\
\mathrm{Cu} \\
\mathrm{Hg} \\
\mathrm{Ni} \\
\mathrm{Pb} \\
\mathrm{Se} \\
\mathrm{Zn}\end{array}$ & $\begin{array}{l}1.0 \\
1.0 \\
0.1 \\
1.0 \\
1.0 \\
0.02 \\
1.0 \\
1.0 \\
0.1 \\
1.0\end{array}$ & $\begin{array}{l}28 \\
28 \\
28 \\
28 \\
28 \\
28 \\
28 \\
28 \\
28 \\
28\end{array}$ & $\begin{array}{c}\cdots-(b) \\
75-120 \\
85-115 \\
75-125 \\
\cdots \\
75-115\end{array}$ & $\begin{array}{l}15 \\
15 \\
15 \\
15 \\
15 \\
15 \\
15\end{array}$ \\
\hline
\end{tabular}

Organic

Compounds

$\begin{array}{lllll}\text { Butyltins } & 0.01 & 28 & 40-140 & 20 \\ \text { PCBs (c) } & 0.02 & 28 & 50-150 & 50 \\ \text { PAHs (d) } & 0.02 & 28 & 50-150 & 50 \\ \text { Pesticides (e) } & 0.002 & 28 & 50-150 & 50\end{array}$

(a) Target detection limits; all efforts were made to reach lowest practical detection limits.

(b) Not available.

(c) Reported as Aroclor equivalents 1242, 1248, 1254, and 1260 and total PCB, EPA Method 8080.

(d) All compounds on EPA Method 610 list. Analyzed using Method 8270 in S.I.M. mode.

(e) All compounds on EPA Method 608 list. Analyzed using Method 8080.

Grain size analyses of Oakland Phase III A sediment samples were performed at the MSL. Grain size was determined by a combination of sieve and pipet techniques following the Puget Sound Estuary Program (PSEP) Protocols for Measuring Selected Environmental Variables in Puget Sound (PSEP 1986). These methods are consistent with ASTM D421 (ASTM 1978) and D422 (ASTM 1972) (with the substitution of the No. 100 Sieve for the No. 120 sieve). Table 2.4 presents the fractions measured.

Approximately $25 \mathrm{~g}$ of each sediment sample was analyzed for total solids while another 10- to 100-g aliquot was weighed for grain size analysis. To separate the coarser sand and gravel fraction from the silt/clay fraction, sediment was washed with distilled water through a $63.5 \mu \mathrm{m}$ 
TABLE 2.4. Grain Size Fractions Measured

\begin{tabular}{ccc} 
Grain Size $(\mu \mathrm{m})$ & Phi & ScreenNumber \\
\cline { 2 - 3 } 3350 & -2 & 6 \\
2000 & -1 & 10 \\
1000 & 0 & 18 \\
500 & 1.5 & 35 \\
250 & 2 & 60 \\
125 & 3 & 120 \\
62.5 & 4 & 230 \\
48 & 4.5 & NA(a) \\
31.2 & 5 & NA \\
23 & 5.5 & NA \\
15.6 & 6 & NA \\
7.8 & 7 & NA \\
3.9 & 8 & NA \\
1.9 & 9 & NA \\
0.976 & 10 & NA \\
0.4883 & 11 & NA
\end{tabular}

(a) Not applicable.

(4.0 phi) sieve into a 1-L graduated cylinder. The coarse fraction was dried, weighed, and shaken through a nest of sieves to yield the required seven coarse subfractions. Any material still passing the final $63.5-\mu \mathrm{m}$ sieve was added to the previous fines in the 1-L graduated cylinder.

The silt/clay fraction was then subdivided by a pipet technique based on Stoke's Law of differential settling velocities for different sized particles. The silt/clay fraction was disassociated by a dispersant in distilled water in a 1-L gradua+od cylinder. At specified time intervals and specified depths below the surface, $20-\mathrm{mL}$ aliquots were withdrawn from the graduated cylinder, delivered to a preweighed container, and dried at $90^{\circ} \pm 2^{\circ} \mathrm{C}$ to a constant weight. Duplicate analysis of one sample was performed as a quality control measure. Other quality control measures, such as spikes, SRMs, or minimum detection limits, do not apply to grain size analysis.

Total organic carbon is the amount of non-volatile, partially volatile, volatile, and particulate organic compounds in a sample. Analysis of TOC was performed by Global Geochem in Canoga Park, California. Each sediment sample was dried and ball milled to a fine powder. Before combustion, inorganic carbonate in the sample was removed by acidification. The TOC in sediment was then determined by measuring the carbon dioxide released during combustion of the sample (PSEP 1986; SW846 Method 9060, EPA 1986b), reported as percent of dry weight. Quality control measures included duplicate analysis on $10 \%$ of the samples and analysis of the SRM MESS-1. 
Total oil and grease includes vegetable oils, animal fats, soaps, waxes, and any other carbon-hydrogen material extractable by the solvent Freon. Total petroleum hydrocarbons are the nonpolar mineral fraction of total oil and grease. These analyses were performed by Twin City Testing at St. Paul, Minnesota. Infrared spectrophotometry (IR) was used to determine concentrations of oil and grease (Method 413.2, EPA 1979) and petroleum hydrocarbons (Method 418.1, EPA 1979). A 20-g aliquot of sample was dried with anhydrous sodium sulfate, then extracted with Freon. For total ril and grease, sample extracts were scanned from 4000 to 600 $\mathrm{cm}^{-1}$ on an infrared spectrophotometer and the peak height measured at $2930 \mathrm{~cm}^{-1}$. This wavelength represents the $-\mathrm{CH}_{2}$ configurations of hydrocarbons and was the standard used to determine oil and grease. For total petroleum hydrocarbons, silica gel was added to the extract to remove the more polar animal and vegetable based oils. The extract was then shaken and allowed to settle. An aliquot was then removed and scanned the same way as the oil and grease sample. The relationship of peak height to oil concentration was determined by regressing the peak height versus a known concentration of fuel oil.

Total volatile solids are a measure of the fraction of total solids that are lost on ignition at a higher temperature than that used to determine total solids. TVS are used as an estimate for the amount of organic matter in the total solids. Operationally, TVS are defined by the combustion temperature, and do not always represent the organic content of a sample because some organic material may be lost at the drying temperature and some inorganic material may be lost at the ignition temperature. Analysis of TVS was performed by the MSL using the method defined in the Puget Sound Estuary Protocols (PSEP 1986). Following that method, the sample was freezedried to constant weight and ball milled to a fine powder. A portion was then removed, weighed, and combusted at $550^{\circ} \mathrm{C}$. The sample was cooled in a desiccator and then reweighed. The amount of sample lost during ignition was then defined as the volatile fraction.

Sediment samples used for determination of percent solids are prepared in one of two ways. (Each laboratory performs a percent solids analysis to determine a sample dry weight; different laboratories may use one of the two methods.) Pre-weighed wet samples are either freezedried over a period of 4 days or baked at $110^{\circ} \mathrm{C}$ for at least $8 \mathrm{~h}$, and cooled in a desiccator. The ratio of dry weight to wet weight is multiplied by 100 to determine the percent solids.

\subsubsection{Metals}

Ten metals were measured in sediments and tissues: silver (Ag), arsenic (As), cadmium $(\mathrm{Cd})$, chromium $(\mathrm{Cr})$, copper $(\mathrm{Cu})$, mercury $(\mathrm{Hg})$, nickel $(\mathrm{Ni})$, lead $(\mathrm{Pb})$, selenium $(\mathrm{Se})$, and zinc $(\mathrm{Zn})$. All metals analyses were performed at the PNL. Samples of sediment, $M$. nasuta tissue, 
and $N$. caecoides tissue were analyzed using a combination of four different methods: 1 ) energydiffusive $x$-ray fluorescence (XRF), following standard PNL methods; 2) Zeeman graphitefurnace atomic absorption spectroscopy (GFAA), following EPA SW-846 Method 7000 (1986b) and the method of Bloom and Crecelius (1984); 3) cold-vapor atomic absorption spectroscopy (CVAA), according to EPA SW-846 Method 7471 (1986b) and the method of Bloom and Crecelius (1983); and 4) inductively coupled plasma emission-mass spectrometry (ICP-MS), according to EPA SW-846 Method 6010 (1986b). The analytical methods for each sample matrix and corresponding metals for which each method was used are presented in Table 2.5.

To prepare sediment and tissues for analysis, samples were freeze-dried, then blended in a Spex mixer-mill. Approximately $5 \mathrm{~g}$ of mixed sediment was ground in a ceramic ball mill. The XRF analysis was performed on a $0.5-\mathrm{g}$ aliquot of dried, ground sediment pressed into a pellet with a diameter of $2 \mathrm{~cm}$. For GFAA, ICP-MS, and CVAA analyses, $0.2-$ to $0.5-\mathrm{g}$ aliquots of dried homogenous sediment went through an acid digestion process to separate and isolate the metals from the matrix.

Quality control measures for metals analyses included analysis of blanks (not applicable to XRF technique), triplicate analyses for each batch of up to 20 samples, and analysis of at least one SRM sample per 20 samples. SRMs for sediment were SRM 1646, obtained from the National Institute of Science and Technology (NIST), and MESS-1 and PACS-1, obtained from the National Research Co'uncil of Carada (NRCC). The tissue SRMs included an oyster tissue, 1566a, obtained from NRCC.

\subsubsection{Chlorinated Pesticides and PCBs}

Chlorinated pesticides and PCBs in sediments and tissues were quantified by gas chromatography/electron capture detection (GC/ECD) following EPA SW-846 Method 8080 (1986b). The PCB and pesticide analyses for Oakland Phase III A sediment samples and approximately half of the M. nasuta samples were performed at Analytical Resources, Inc. (ARI). Twin City Testing analyzed the remaining $M$. nasuta samples and the Oakland Phase III A retest sediments. Alden Analytical in Seattle, Washington, analyzed the $N$. caecoides samples for PCBs and pesticides.

Chlorinated pesticides and PCBs were extracted simultaneously with the PAH compounds using EPA SW-846 Method 3540 (1986b). The procedure involved a methylene chloride extraction using either soxhlet or sonication extraction techniques. A portion of the methylene chloride extract was solvent exchanged to hexane, and interferences were removed by passing the extract through a column packed with $10 \mathrm{~g}$ of $7 \%$ deactivated alumina. Most samples required an 
TABLE 25. Analytical Method and Corresponding Metal for Each Sample Matrix

\begin{tabular}{lcr}
\multicolumn{3}{c}{ Sediment } \\
\cline { 1 - 3 } GEA & XRE & CVAA \\
\cline { 3 - 3 } $\mathrm{Ag}$ & $\mathrm{As}$ & $\mathrm{Hg}$ \\
$\mathrm{Cd}$ & $\mathrm{Cr}$ & \\
$\mathrm{Se}$ & $\mathrm{Cu}$ & \\
& $\mathrm{Ni}$ & \\
& $\mathrm{Pb}$ & \\
& $\mathrm{Zn}$ &
\end{tabular}

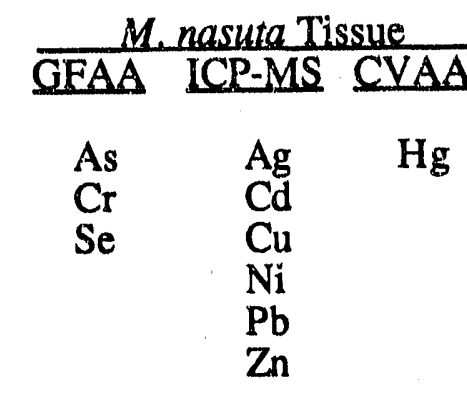

\section{$\frac{N \text { caecoides Tissue }}{\text { GEAA XRE CVAA }}$}

$\begin{array}{lll}\mathrm{Ag} & \mathrm{As} & \mathrm{Hg} \\ \mathrm{As} & \mathrm{Cu} & \\ \mathrm{Cd} & \mathrm{Ni} & \\ \mathrm{Cr} & \mathrm{Se} & \\ \mathrm{Cu} & \mathrm{Zn} & \\ \mathrm{Ni} & \\ \mathrm{Pb} & \\ \mathrm{Se} & \\ \mathrm{Zn}(\mathrm{a}) & \end{array}$

(a) For composited samples. (Note: Because of limited sample quantity, some $N$. caecoides tissue samples were composited by sediment treatment).

additional cleanup treatment using gel permeation chromatography (GPC) to remove other interferences. Analytical quantification was performed using GC/ECD analysis.

Dibutylchlorendate (DBC) was the surrogate compound added to each sample before extraction to assess extraction efficiency.

A matrix spiking solution, consisting of either a subset of pesticides or one Aroclor, was also added to the appropriate samples before extraction. Matrix spike/matrix spike duplicate analyses were conducted to assess accuracy and precision of the measurement. A method blank was analyzed along with this set of samples as well.

\subsubsection{Semivolatile Organic Compounds}

The semivolatile organic compounds analyzed in sediments were the 16 PAHs listed in EPA Method 610. These compounds were extracted from sediments following EPA SW -846 Method 3540 (1986b) using methylene chloride as the extraction solvent. A portion of the extract was used for PAH analysis by gas chromatography/mass spectroscopy in the Selective Ion Mode (GC/MS SIM) following EPA SW-846 Method 8270 (1986b). Tissue extracts were run through GPC prior to analysis to remove any additional interferences. Analytical Resources, Inc. conducted PAH analysis for Oakland Phase III A sediment samples and approximately half of the $M$. nasuta samples. Twin City Testing analyzed the remaining $M$. nasuta samples and the Oakland Phase III A retest sediments. Alden Analytical in Seattie, Washington, conducted analyses of the $N$. caecoides samples for PAHs. 
At least three PAH surrogate compounds were added to all samples prior to extraction and a subset of PAH compounds was added to a selected sample in duplicate to assess accuracy and precision of the analyses. National Research Council of Canada SRM HS-5, a sedirnent sample of known PAH concentrations, was also analyzed for PAH compounds along with the sediments from the Oakland Phase III A retests, although the levels of PAH compounds in this SRM are relatively high compared to the levels measured in the samples.

\subsubsection{Butyltins}

Butyltin compounds in sediment and tissues were analyzed using gas chromatography with flame photometric detection (GC-FPD) following the methods of Unger et al. (1986). Butyltins in sediment and $M$, nasuta tissue were analyzed at MSL in Sequim, Washington, and butyltins in $N$. caecoides samples were analyzed at Battelle Ocean Sciences in Duxbury, Massachusetts.

Wet samples were extracted with methylene chloride and tropolone. Propyltin was added before extraction as a surrogate compound to assess extraction efficiency. The mono-, di-, triand tetra-butyltin compounds extracted from the sediment and tissues were derivatized with nhexyl magnesium bromide to a less volatile, more thermally stable form (nonionic $n$-hexyl derivatives).

The extracts were passed through a florisil liquid chromatography column for cleanup, and the butyltins were quantified by GC-FPD. Concentrations were reported in $\mu \mathrm{g} / \mathrm{kg}$ dry weight of mono-, di-, tri- and tetra-butyltin species as tin. The recently certified reference material for butyltins, NRCC SRM PACS-1, was analyzed with Oakland Phase III A sediment. Selected sediment and tissue samples were spiked with di- and tri-butyltins prior to extraction to assess the accuracy of the procedure. Method blanks were analyzed with each batch of samples extracted.

\subsection{SOLID-PHASE TOXICOLOGICAL TESTTNG PROCEDURES}

The laboratory facilities at MSL were set up to provide the required conditions for the SPP static bioassays and either flow-through or static solid-phase bioassays for the toxicological and bioaccumulation testing program. Thirty-one constant-temperature water baths were set up. These water baths supported the following bioassays:

- 10- and 28-Day Solid-Phase Flow-Through Test with M. nasuta and N. caecoides

- 10-Day Solid-Phase Flow-Through Test with C. stigmaeus

- 10-Day Solid-Phase Static and Flow-Through Tests with $R$. abronius 
- 96-h Suspended-Particulate-Phase Static Test with H. sculpta

- 96-h Suspended-Particulate-Phase Static Test with C. stigmaeus

- 48-h Suspended-Particulate-Phase Static Test with Larval C. gigas

The facilities provided air, temperature, and lighting control, as well as flow-through water supply as needed.

The solid-phase tests evaluated effects from both the physical presence of dredged sediment and the toxicity of contaminants associated with them. The tests were conducted with four marine species: a burrowing, detrital-feeding clam; a burrowing, deposit-feeding polychaete; a dermersal fish; and a burrowing crustacean. Selection of these animals allowed examination of differential effects in relation to differences in feeding and life habits.

\subsubsection{0-and 28-Day Solid-Phase Flow-Through Test With $M$. nasute and $N$. caecoides}

The flow-through tests using the bent-nose clam M. nasuta and the polychaete $N$. caecoides were conducted in 10-gal test aquaria that were placed on the water tables according to randomization sheets, and filled with approximately $8 \mathrm{~L}$ of sand-filtered seawater via the flowthrough system. The test sediment was added to a depth of $3 \mathrm{~cm}$ by measuring out the required amount $(3870 \mathrm{~mL})$ in a clean glass container, and using the seawater in the aquarium to wash and distribute the sediment evenly. The flow-through system (Figure 2.9) was initiated, and aquaria were allowed to fill to a total volume of approximately $36 \mathrm{~L}$. For approximately $4 \mathrm{~h}$, suspended materials in the aquaria were allowed to settle and the flow-through systerm was adjusted and calibrated to deliver $120 \pm 10 \mathrm{~mL} / \mathrm{min}$ of seawater flow to each aquarium. The system was allowed to run overnight before the organisms were added. $M$. nasuta and $N$. caecoides were collected from the holding tanks and placed in the aquaria in the following amounts:

- 10-Day Acute Test - 136 tanks containing $20 \mathrm{M}$. nasuta and $20 \mathrm{~N}$. caecoides each

- 28-Day Bioaccumulation Test - 140 tanks containing 25 M. nasuta and $30 \mathrm{~N}$. caecoides each

The initiation date, time and analyst's initials were indicated on the aquarium. The 10-day and 28-day tests began when organisms were placed into the tanks. Daily observations were made on animal behavior, flow rate and water quality parameters of salinity, temperature, $\mathrm{DO}$, and $\mathrm{pH}$. These were performed in at least one replicate of each treatment and recorded on water quality data sheets. (Water quality data are provided in Volume 2, Appendixes $\mathrm{E}$ through $\mathrm{H}$ ). The water quality parameters and ranges established for the tests were 


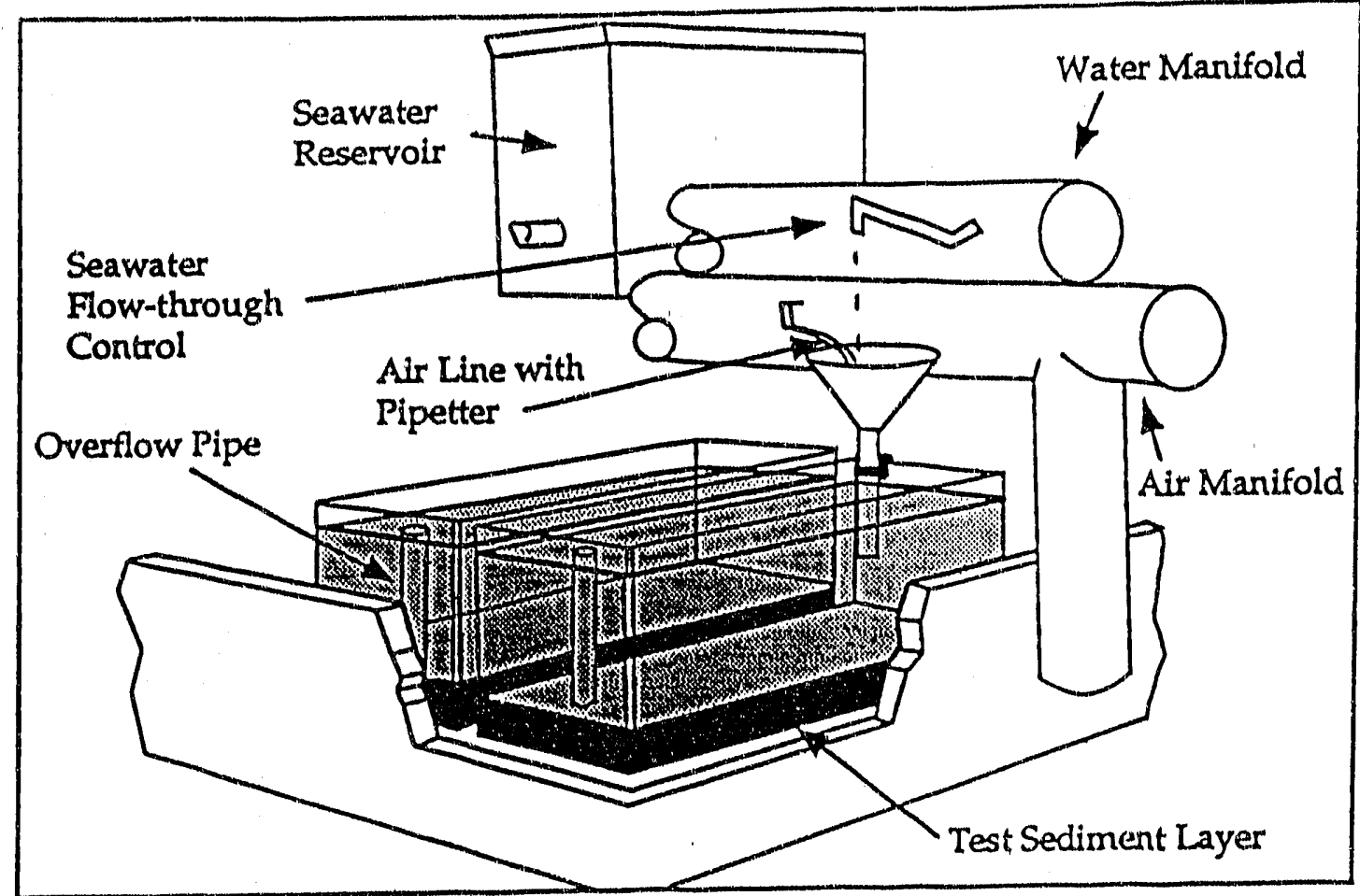

EIGURE 2.2. Flow-Through Aquarium for $M$. nasuta, $N$. caecoides, and $C$. stigmaeus

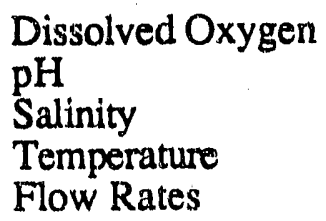

$$
\begin{aligned}
& \geq 4.0 \mathrm{mg} / \mathrm{L} \\
& \text { ambient } \pm 0.5 \text { units } \\
& \text { ambient } \pm 2.0 \% \\
& 15^{\circ} \mathrm{C} \pm 2.0^{\circ} \mathrm{C} \\
& 120 \pm 10 \mathrm{~mL} / \mathrm{min} .
\end{aligned}
$$

The number of dead organisms present was monitored daily. Dead organisms were removed but not replaced. The number of $M$. nasuta on the sediment surface and the number of siphons exposed were observed daily, as were the number of $N$. caecoides on the surface of the sediment and the number with only their heads exposed. If any dead $N$. caecoides was removed, the specimen was identified either as a whole animal or a head or tail portion. All observations were recorded.

At the end of the 10-day test, a water quality check was performed in all tanks and the contents of each aquarium were gently passed through a $1.0 \mathrm{~mm}$ Nytex screen to recover the $M$. nasuta and $N$. caecoides. The organisms were then placed in a glass baking dish labeled with the treatment number. From here the number of dead and live of each species was determined. Acute toxicity was determined by observing whether the $N$. caecoides reacted to gentle probing. If 
there was no reaction, they were considered dead. Acute toxicity in the M. nasuta was determined by observing and counting dead individuals. Those with gaping shells were considered dead. The mortality data were recorded on the Termination Forms. As a quality control check of the counts, $10 \%$ of the test containers were recounted by a second analyst.

In the 28-day test, the living $M$. nasuta and $N$. caecoides were chemically evaluated for bioaccumulation. They were initially processed in the same manner as the 10-day test organisms but were then transferred to separate tanks to allow them to depurate for $24 \mathrm{~h}$. M. nasuta tanks were filled with clean seawater and $N$. caecoides tanks contained clean sediment. Clean sediment was necessary for $N$. caecoides because these organisms require sediment to surround their tissues, or they will die. During this time, the animals were not fed and the fecal material and debris were removed daily during water quality monitoring. At the end of the depuration period, the clams' shells were cleaned with a scrub brush and the tissues from the clams were dissected using titanium instruments and collected for chemical analysis. The worns were gently washed in clean seawater to remove external sediment grains and put in containers for chemical analysis.

Results of the $N$. caecoides 10 and 28-day tests showed $86 \%$ control survival and $58.7 \%$ control survival, respectively. These percentages were below the $90 \%$ control survival (10 day) and $80 \%$ control survival (28 day) specified in the QA plan. As a result, sediment samples were collected again at the following stations and retested using $M$. nasuta and $N$. caecoides: I-C3, I-C5, I-C7 through I-C12, I-C14 through I-C18, I-S1, I-T1, and I-T3. The control and reference sediments used for the $M$. nasuta/ $N$. caecoides retest were C-NE, C-WB, C-SB, R-PF, R-PC, R-BF, R-OS, R-AC, and R-AM.

\subsubsection{0-Day Solid-Phase Flow-Through Test with C.stigmaeus}

The solid-phase flow-through test for $C$. stigmaeus used 104, 10-gal aquaria that were positioned on the water tables using randomization sheets. Approximately $8 \mathrm{~L}$ of sand-filtered seawater was added to each aquarium to a depth of $3 \mathrm{~cm}$ by measuring out the required amount $(3870 \mathrm{~mL})$ in a clean glass container and using the seawater in the aquarium to wash and distribute the sediment evenly. Each aquarium was filled over a period of approximately $4 \mathrm{~h}$, allowing suspended particles to settle. Seawater was circulated overnight via the flow-through system at a flow rate of $120 \mathrm{~mL} / \mathrm{min}( \pm 10 \mathrm{~mL} / \mathrm{min})$. Initial water quality parameters and flow-through rates were measured on every test container. Ten $C$. stigmaeus were randomly collected from the holding tanks and placed in each aquarium. Initiation date, time, and analyst's initials were indicated on the aquarium. The animals were checked after $2 \mathrm{~h}$; dead or impaired organisms were removed and replaced. Organisms were considered impaired if they swam abnormally or were 
unable to orient themselves dorsal-ventrally. Biological observations and the number of live and dead in each test container were recorded daily. Water quality parameters and flow rates were measured daily in at least one replicate of each treatment and recorded on the water quality data sheets. Acceptable water quality parameters and ranges during the experiment were

$\begin{array}{ll}\text { Dissolved Oxygen } & \geq 4.0 \mathrm{mg} / \mathrm{L} \\ \text { pH } & \text { ambient } \pm 0.5 \text { units } \\ \text { Salinity } & \text { ambient } \pm 2.0 \% \\ \text { Temperature } & 15^{\circ} \mathrm{C} \pm 2.0^{\circ} \mathrm{C} \\ \text { Flow Rate } & 120 \pm 10 \mathrm{~mL} / \mathrm{min} .\end{array}$

During the test, all dead fish were removed and placed in individually labeled 50-mL centrifuge tubes and stored in the freezer. At the end of the test, water quality parameters were measured on all replicates and the number of living and dead C. stigmaeus were counted and indicated on the termination form. Live fish from each of the SPP treatments were placed in a clean, labeled glass jar and preserved in Davidson's solution for histopathological analysis, if required.

\subsubsection{0-Dav Solid-Phase Static and Flow-Through Tests with $R$ abronius}

The $R$. abronius test used 420,1-qt mason jars (Figure 2.10) as the test containers that were placed on a water table at $15^{\circ} \mathrm{C}$ according to randomization sheets. Three types of amphipod tests were conducted: 1) a flow-through jar with aeration, 2) a flow-through jar without aeration, and 3) a static test with aeration. Each test setup will be described and any variance in procedures noted.

Each test ran for a total of 10 days. In the flow-through test with and without aeration, test sediment was sieved through a $0.5-\mathrm{mm}$ screen, added to the jars to a depth of $3 \mathrm{~cm}$, and then slowly allowed to fill via the flow-through system. The water circulated for $1 \mathrm{~h}$ at a flow rate of $40 \mathrm{~mL} / \mathrm{min}$ ( $\pm 5 \mathrm{~mL} / \mathrm{min}$ ). Aeration was started if required for that test. The flow rate was adjusted, if necessary, and initial water quality was checked on each container during this time. Each test container required $20 R$. abronius. Collection was done by gently sieving the sediment in the holding containers, and transferring five organisms to four plastic $50-\mathrm{mL}$ containers, each filled with $20 \mathrm{~mL}$ of holding water. The animals were not allowed to be exposed to air. The $R$. abronius were then gently added to a test container by swirling the 50 -mL plastic container and pouring the water and organisms into the exposure jar. The test initiation date, time, and analyst's initials were indicated on each container. After $1 \mathrm{~h}$, any non-burying amphipods were removed and replaced. 


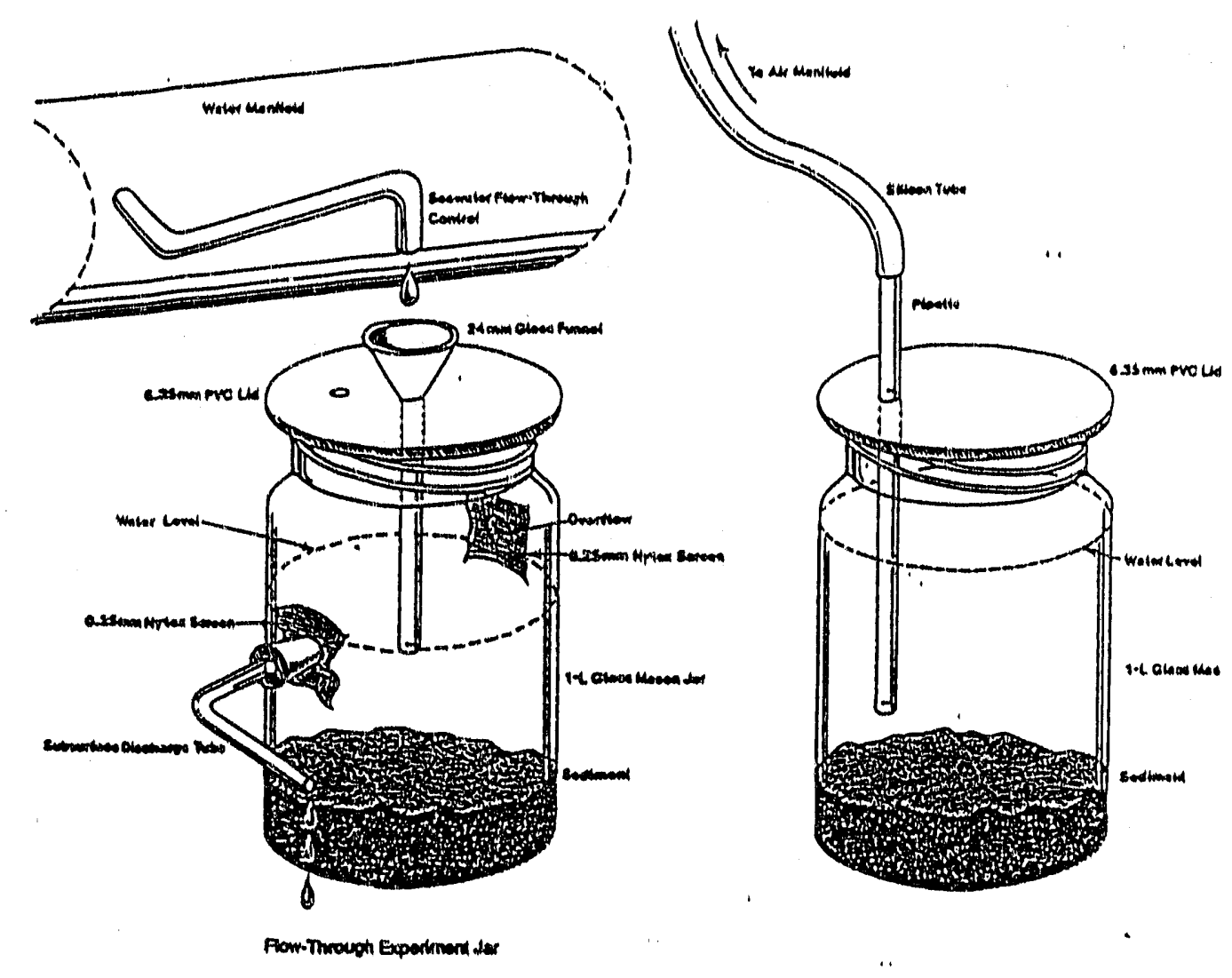

FIGURE 2.10. Static and Flow-Through Amphipod Testing Jars

The static test followed the same procedures except that the water was added manually to reach a total volume of $750 \mathrm{~mL}$. The reference toxicant test was static, without sediment, and ran for 4 days. Four concentrations of cadmium chloride were prepared according to the test plan. Five replicates of each concentration, including a blank containing seawater only, were placed randomly on the water table. Each mason jar was filled to a total volume of $750 \mathrm{~mL}$ with filtered $(0.45 \mu \mathrm{m})$ seawater. The jars were aerated and allowed to incubate for $24 \mathrm{~h}$ to stabilize temperature and $\mathrm{pH}$ to test conditions. Initial water quality checks were performed on each concentration and recorded on water quality forms. Daily animal observations were made, and the number of anirnals floating on the surface, swimming in the jar, or settling on the sediment 
were recorded on observation forms. Animals that were floating on the surface were gently pushed below the water surface with a pipet tip and observed as they either buried or did not rebury into the sediment. Water quality measurements of temperature, salinity, $\mathrm{pH}$, and DO were performed dally. All containers were checked at the beginning and end of the biotssay. One replicate of each exposure and concentration was checked daily. Acceptable water quality values and ranges were

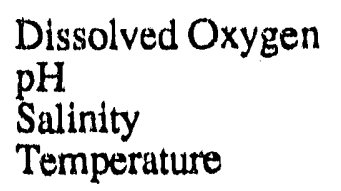

$$
\begin{aligned}
& 24.0 \mathrm{mg} / \mathrm{L} \\
& \text { amblent } \pm 0.5 \text { units } \\
& \text { amblent } \pm 2.0 \% \text { \% } \\
& 15^{\circ} \mathrm{C} \pm 2.0^{\circ} \mathrm{C} .
\end{aligned}
$$

At the end of the test, the contents of each jar were placed in a $0.5-\mathrm{mm}$ Nytex screen to collect the $R$. abronius and then placed in a glass finger bowl labeled with the treatment number. Counts were performed on each dish to determine the numbor of live or dead organisms, and the presence or absence of body parts recovered at the end of the test. The acute toxicity was observed by gently probing the animal and noting whether it reacted to the probing based on the pleopod movement. The mortality data were recorded on termination sheets. As a quality control check of the counts, $10 \%$ of the test containers were recounted by a second analyst.

\subsection{SUSPENDED-PARTICULATE-PHASETESTS}

\subsubsection{6-h Suspended-Particulate-Phase Static Test with H. sculpto}

Test containers used for the H. sculpta SPP test were 2-L glass baking dishes. Sixty test containers were distributed as follows:

4 SPP treatments, each at 4 concentrations; 3 replicates of each $=48$ 3 reference toxicant concentrations; 2 replicates of each $=$ 6 Alcatraz reference water $=$ TOTAL $=$

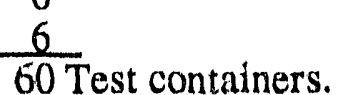

The test containers were marked at the $1000-\mathrm{mL}$ mark and positioned on the water table according to randomization sheets provided. A total of 1.5 gal of SPP was needed from each treatment for each test. The SPP concentrations were 0\% (seawater), 10\%, 50\%, and 100\% for each SPP treatment. After the SPP concentration was in the test container, aeration and an initial water quality check were performed on all replicates. H. sculpta were randomly removed from the holding containers and added to each test container (10 animals per exposure chamber) using a minimum amount of holding water. The initiation time and date were indicated on the test container and data sheet. Biological observations were made at $0,4,8,24,48,72$, and $96 \mathrm{~h}$. At 
each observation period, the number of dead and live animals was recorded on the observation form. Death was considered to be a lack of movement in response to touching the animal lightly with a clean probe, or by swirling the test dish gently to determine movement. Dead animals, molted exoskeletons, and/or excess food were removed at each observation period. Temperature, salinity, $\mathrm{pH}$, and DO were measured daily in at least one test replicate and recorded on the water quality data sheets. The acceptable water quality parameters and ranges during the experiment were

Dissolved Oxygen
pH
Salinity
Temperature

$$
\begin{aligned}
& \geq 4.0 \mathrm{mg} / \mathrm{L} \\
& \text { ambient } \pm 0.5 \text { units } \\
& \text { ambient } \pm 2.0 \% \\
& 15^{\circ} \mathrm{C} \pm 2.0^{\circ} \mathrm{C} .
\end{aligned}
$$

\subsubsection{6-in Suspended-Particulate-Phase Static Test with C stigmaeus}

Test containers used for the $C$. stigmaeus SPP test were 10-gal aquaria. Fifty-one test containers were distributed as follows:

4 SPP treatments, each at 4 concentrations; 3 replicates of each $=48$
3 Alcatraz reference water $=$ TOTAL =
$\frac{3}{51 \text { Test containers }}$

Test containers were positioned on the water table according to randomization sheets provided. Each container was filled to a volume of $16 \mathrm{~L}$. The SPP concentrations were $0 \%$ (seawater), $10 \%$, $50 \%$, and $100 \%$ for each SPP treatment. Sequim Bay $(0.45-\mu \mathrm{m}$ filtered) seawater was used as dilution water in all tests. Aeration and an initial water quality check were provided in all tanks. Fish were not fed during the test. Following SPP preparation, $10 \mathrm{C}$. stigmaeus were randomly selected from the holding tank and transferred with a fine-mesh dip net to a transfer container, then to each of the test tanks. The test was initiated immediately after transfer of the fish, and the time and date were noted on the test container. Biological observations were made at $0,24,48,72$, and $96 \mathrm{~h}$, recording the number of $C$. stigmaeus swimming and resting in each tank on the observation form. Resting fish were touched gently with a probe to determine any movement before the number of dead was determined. Dead animals were removed and examined at each observation period. Temperature, salinity, pH, and DO measurements were recorded daily in one replicate of each exposure. Tanks with high mortalities received a complete water quality check. The acceptable water quality parameters and ranges during the experiment were

$\begin{array}{ll}\text { Dissolved Oxygen } & \geq 4.0 \mathrm{mg} / \mathrm{L} \\ \text { pHI } & \text { ambient } \pm 0.5 \text { units } \\ \text { Salinity } & \text { ambient } \pm 2.0 \% 0 \\ \text { Temperature } & 15^{\circ} \mathrm{C} \pm 2.0^{\circ} \mathrm{C} .\end{array}$


During the test, all dead fish were removed and placed in individually labeled 50-tnL. centrifuge tubes and put in the freezer. At the end of the test, a water quality check was performed on all replicates and the number of living and dead $C$. stigmaeus was determined and indicated on the termination form. Live fish from each of the SPP treatments were placed in a clean, labeled glass jar and preserved in Davidson's solution for histopathological analysis.

\subsubsection{8-h Suspended-Particulate-Phase Static Test with Larval C. gigas}

Test containers used for the C. gigas SPP test were 1-L mason jars. Seventy-eight test containers were distributed as follows:

$\begin{array}{ll}4 \text { SPP treatments, each at } 4 \text { concentrations; } 4 \text { replicates of each }= & 64 \\ 5 \text { reference toxicant concentrations; } 2 \text { replicates of each }= & 10 \\ 4 \text { Alcatraz reference water }= & \frac{4}{78} \text { Test containers } \\ \text { TOTAL }= & \end{array}$

The test containers for the larval test were marked at $750 \mathrm{~mL}$ and positioned on the water tables according to randomization sheets. The SPP concentrations of $0 \%$ (reference water), $10 \%, 50 \%$, and $100 \%$ were made with Strait of Juan de Fuca water (32\%) diluted with deionized water to $26 \%$. After preparing the SPP and placing it in the test container, aeration and an initial water quality check were performed. C. gigas in spawning condition were obtained and spawned by placing the animals in individual glass baking dishes containing warm $\left(30^{\circ} \mathrm{C}\right)$ seawater. If spawning did not occur, the oysters were spawned by a technique called "strip spawning" (Dupuy et al. 1977). Using this technique, the oyster was opened 'y cutting the adductor muscles. The mantle and gonads were then sliced open with a series of shallow cuts, using a clean scalpel. The contents of the gonad were washed into a clean Pyrex baking dish using a squeeze bottle of $26 \%$ seawater, and the gametes were examined under a compound microscope to determine sex and state of development. Normal-appearing, pear-shaped eggs and motile, viable sperm were saved and mixed in a clean $1500-\mathrm{mL}$ beaker and diluted to approximately $100 \mathrm{~mL}$ with $26 \%(0.45 \mu \mathrm{m})$ filtered seawater. They were incubated for $1 \mathrm{~h}$ at $20^{\circ} \mathrm{C}$, aerated, and frequently stirred with a perforated plunger. After $1 \mathrm{~h}$, the material in the beaker was poured through a $20-\mu \mathrm{m}$ screen to consolidate the eggs and remove the sperm. The eggs were washed and then placed back in the $1500-\mathrm{mL}$ beaker containing clear $26 \%$ filtered offshore seawater. Fertilization success and fertilized egg density were estimated by mixing the contents with the perforated plunger, then removing a $1-\mathrm{mL}$, sample from the beaker, placing it in a $100 \mathrm{~mL}$ volumetric flask, and filling it to the $100 \mathrm{~mL}$ mark with a $5 \%$ formalin/seawater mixture. A series of $1-\mathrm{mL}$ samples was removed from this 100:1 suspension and the number of fertilized and non-fertilized eggs was counted on a Sedgewick-Rafter counting chamber at low magnification on a compound scope. The mean 
number of fertilized and non-fertilized eggs for the replicate counts was calculated, and this number was multiplied by 100 to account for the 100:1 dilution. This allowed us to estimate the number of fertilized eggs/mL in the stock and to calculate the percent fertilization.

The appropriate amount of the stock was added to each exposure container with a calibrated pipettor to achieve a fertilized egg stocking density of 30 to $40 \mathrm{eggs} / \mathrm{mL}$. The perforated plunger was used to mix the contents of the boaker before removing a sample with the pipettor. The initiation times were recorded. To check actual fertilized egg density, selected reference jars were subsampled $1 \mathrm{~h}$ after fertilization, and the number of fertilized eggs counted on a Sedgowick-Rafter cell. A homogeneous egg density was produced in each container before subsampling by slowly moving a perforated plunger up and down through the water column. This action distributed the fertilized eggs/larvae throughout the container, allowing a representative subsample to be obtained. Immediately after this process, three 10-mL samples were drawn from the test container with a calibrated 10-mL Eppendorf pipet and placed in a labeled scintillation vial containing $1 \mathrm{~mL}$ of $5 \%$ formalin.

Water quality checks were performed in each container daily and recorded on the water quality data sheets. The acceptable water quality parameters and ranges during the experiment were

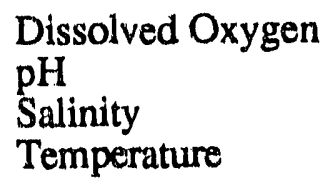

When normal D larvae predominated in control containers ( 2 to 3 days), the test was terminated by homogenizing the contents of each container and immediately removing a $30-\mathrm{mL}$ subsample with a calibrated pipettor. Each subsample was placed in a labeled $50-\mathrm{mL}$, centrifuge tube and preserved with formalin/seawater for a final concentration of $4 \%$ formalin. Samples were counted by centrifuging at high speed for $10 \mathrm{~min}$, then drawing the bottom $2 \mathrm{~mL}$ from a tube and counting the number of normal D-shaped, abnormally developed, blastula-stage, and total number of larvae (in the $30-\mathrm{mL}$ subsarnple).

\subsection{DATAANALYSIS AND INTERPRETATION}

Several statistical analyses were conducted to determine the magnitude and significance of toxicity and bioaccumulation in test treatments relative to reference treatments. Each statistical test is based upon a completely random design that allows unbiased comparison between treatments. The Draft Implementation Manual recommends Dunnett's Test for comparing test treatments to a 
single reference treatment. However, the Oakland Phase III A experiments were conducted with multiple reference treatments because a single reference most representative of a potential disposal site had not been selected. Because it is only appropriate for comparison to a single reference, Dunnett's Test could not be used for comparing Oakland Harbor Phase III A test sediments to all the reference sediments that were tested. In this case, Dunn's Test, a modification of Tukey's Honestly Significant Difference (HSD) Test, is appropriate and was used to compare the test treatments to all the reference treatments while maintaining the experiment-wise error rate. The alpha level was expanded to 0.1 for both bioaccumulation and toxicity comparisons in order to increase the comparison-wise error rate, which becomes smaller as the number of comparisons increases. This implies that the test is statistically less conservative, meaning that it is less likely to fail to detect a significant difference than comparisons at $\alpha=0.05$. Comparisons conducted at $\alpha=$ 0.05 are less sensitive to differences in means, resulting in fewer significant differences. Test design and specific statistical analysis procedures are discussed in the following sections.

\subsubsection{Randomization}

All solid phase and SPP toxicity tests were designed as completely random tests. Organisms were randomly allocated to treatments, and treatments were randomly positioned on water tables. A random number table for this purpose was generated for each toxicity test, using the discrete uniform random number generator in the Lotus 123 spreadsheet. For the SPP tests, $H$. sculpta and $M$. edulis larvae were randomly allocated to SPP replicates for all concentrations. Special care was taken with $C$. stigmaeus individuals in order to eliminate bias caused by variable mobility of the fish (otherwise, easily caught fish would be used earlier than more mobile fish).

\subsubsection{Statistical Analysis of Solid-Phase Tests}

Solid-phase toxicity of all sediment treatments was compared by analysis of variance (ANOVA) tests on the arcsine square-root of the proportion of organisms surviving the test. The arcsine square-root transformation stabilizes the within-class variances to meet the assumptions of the ANOVA. All treatments were compared using the conservative Dunn's Test for comparison of all means (Dunn 1961), using an experiment-wise error rate $(\alpha=0.1)$. Dunn's Test is similar to Tukey's HSD Test that had been used for previous Oakland Harbor projects, but Dunn's modification accommodates larger numbers of treatments and unbalanced replicates. Both Dunn's and Tukey's HSD Tests are multiple-range comparisons that provide information about how each sediment treatment compares to all other treatments. These statistical methods allow comparison of a test treatment to more than one reference treatment when ali are tested concurrently. Toxicity of a treatment was considered significant if it was statistically different from one or more reference 
treatments and if the survival in the treatment was $\geq 10 \%$ lower than the reference treatment for the test organism ( $\geq 20 \%$ lower than reference for $R$. abronius).

\subsubsection{Statistical Analysis of SPP Tests}

Two statistical tests are presented in the Draft Implementation Manual for the interpretation of SPP tests. The first test is a one-sided t-test between survival in control replicates and survival in the $100 \%$ SPP replicates. This test is performed only when survival in the $100 \%$ SPP is less than control (0\% SPP) survival and when control survival is greater than $90 \%$ (indicating test validity). Prior to conducting the i-test, angular transformation (arcsine of the square root) of the proportion surviving in test replicates is performed to reduce possible heterogeneity of variance between control and $100 \%$ SPP mean survivals. The second test required by the Draft Implementation Manual is an LC50 caiculation, the concentration of SPP that is lethal to 50\% of the individuals tested. The LC50 values for these tests were calculated using the Trimmed Spearman-Karber Method (Firney 1971). The Spearman-Karber estimator is appropriate oriy if there is increasing mortality with increasing concentration and if $50 \%$ or greater mortality is observed in test solutions when normalized to control survival. If $50 \%$ mortality does not occur in the $100 \%$ SPP dilutions for any treatments, then LC50 values are reported as $>100 \%$ SPP. The same method was used to calculate EC50 values (the concentration where $50 \%$ of the test. individuals show a certain effect) for the bivalve SPP test and LC50 values for all reference toxicant tests.

\subsubsection{Statistical Analysis of Bioaccumulation}

Before statistical analysis of $M$. nasuta and $N$. caecoides tissue concentrations, a visual inspection of the tissue chemistry data was performed. If visual inspection showed that a compound was undetected in the majority of replicate samples in test treatments or that the mean tissue concentration in the reference treatments was greater than that in the test treatments, no further analysis was performed. If the detected concentration of a compound exceeded that of any reference treatment, statistical analysis was performed. In all cases, detection limits were used in numerical calculations when a compound was undetected.

Treatments where contaminants of concern were detected were compared to all reference treatments using ANOVA and Dunn's Test for comparison of all means. Analytical detection limit values were used for replicates where the compound was not detected. Significant bioaccumulation of a contaminant was determined by the statistical grouping yielded by Dunn's Test at $\alpha=0.10$. 


\subsection{QUALITYASSURANCE/QUALITY CONTROLPROCEDURES}

The $\mathrm{QA} / \mathrm{QC}$ procedures followed for these studies were consistent with the Implementation Manuals (EPA/USACE 1977 and 1990) and the EPA protocols (PSEP 1986). The procedures followed were documented by Pacific Northwest Laboratory's (PNL) Quality Assurance Division as a QA Plan. A member of PNL's quality assurance staff was present throughout these studies to ensure that accepted procedures were followed. The PNL Laboratory Record Books (LRB) were used for all phases of this project. These LRBs were assigned to each portion of the study and served as records of day-to-day activities during the research. All entries in the LRBs were signed, dated, and reviewed by the project manager. The following discussion summarizes QA/QC procedures followed for the three main portions of this study: sediment sampling, biological testing, and chemical testing. All QA/QC evaluations for sediment chemistry are contained in Volume 2, Appendix C and Appendix D; QA/QC evaluations for tissue chemistry are contained in Volume 2, Appendix $P$ and Appendix $Q$.

\subsubsection{Sample Tracking and Storage}

All samples were accompanied by chain-of-custody forms from the time of collection to receipt at MSL. A new set of custody forms was initiated for sediment subsamples for chemical analyses. These accompanied the samples to the appropriate laboratory where the forms were signed and returned to the MSL project manager. Custody forms were initiated for all tissue samples upon completion of the biolorical testing. These forms accompanied the samples to the appropriate laboratory for chemical analyses.

All sediment collected for these studies was stored in glass, cellulose acetate butyrate containers, or steel drums lined with 9-C-4-A-phenolic epoxy, a noncontaminating coating. Sediment cores and grab samples were stored at $4^{\circ} \mathrm{C}$ prior to biologicul testing. Subsamples for chemical analyses were obtained prior to biological testing. These subsamples were stored frozen until chemical analyses were performed. Samples for organic analyses were stored frozen up to 2 months (PSEP 1986). Samples for metals were freeze-dried upon receipt at the laboratory and held up to 6 months (PSEP 1986; EPA/USACE 1990).

Tissue samples were frozen immediately upon completion of the bioaccumulation tests. Samples for organic analyses were stored in precleaned glass jars with Teflon-lined lids and samples for metals analyses were stored in precleaned plastic jars. Samples for organic analyses were held up to 2 months prior to analysis and samples for metals could be held up to 6 months prior to analysis. 


\subsubsection{Sediment and Tissue Chemistry QA/QC Procedures}

Chemical testing procedures require that specific $\mathrm{QA} / \mathrm{QC}$ protocols be followed. The QA/QC guidelines specific to this project are provided in the Quality Assurance Plan (QAP) for the Oakland Harbor Phase III A Project. These guidelines include the following:

- analysis of a method blank with each batch of samples

- replicate analysis on at least $5 \%$ of the samples (triplicate analyses where possible) to assess analytical precision

- analysis of matrix spikes on $10 \%$ of the samples (where applicable) with appropriate compounds to assess accuracy

- analysis of SRMs at a frequency of 5\%, if available for the parameter and matrix of interest

- archival of all instrument printouts (including raw data and chromatograms from $\mathrm{AA}$ and $\mathrm{GC}$ analyses) for future review.

In actual practice, some of the specific guidelines listed in the QAP for analytical precision and accuracy were modified to apply to the most current methods employed by laboratories. The QA guidelines for detection limits, range of recovery, and relative precision are listed in Table 2.2 for sediments and Table 2.3 for tissues.

Measurements of precision were obtained through replicate analysis of selected sediment treatments. Analysis of replicates shows how precise or repeatable a result is. The QA/QC measurement of precision is the industrial statistic "I" and relative percent difference (RPD) for duplicate analyses, and the relative standard deviation (RSD) for triplicate analyses. The "I" statistic is defined as the absolute value of the difference between duplicate measurements, divided by the sum of the duplicates. The RPD is defined as the absolute value of the difference between two duplicate measurements, divided by the mean of the duplicates, multiplied by 100 . The RSD is defined as the sample standard deviation divided by the mean, multiplied by 100 . The results, including the "I" statistic and RPD, whichever is applicable, are presented in Volume 2, Appendixes $C$ and D, Sediment Chemistry and Quality Assurance Data (first analysis and retest, respectively), and Appendixes $\mathrm{P}$ and $\mathrm{Q}$, Tissue Chemistry and Quality Assurance Data for $M$. nasuta and N. caecoides, respectively.

Measurements of accuracy can be determined by analyzing matrix spikes of known concentrations, as well as surrogate compounds and SRMs that have been certified for the presence of specific parameters. Matrix spikes were analyzed for metals and for organic parameters, including oil and grease, petroleum hydrocarbons, PCBs, pesticides, and PAHs. Spikes generally 
are made up of a subset of the parameters of interest. Spike recoveries were calculated based on the difference between the amount spiked and the amount recovered in the sample, taking into account the native amounts already present in the spiked sample. In some cases, especially those involving the tissue samples, insufficient amounts of actual worm or clam samples remained for spiking. When this was the case, additional untreated clam or worm samples were used for spiking purposes. These still represent the matrix being analyzed. Spikes for metals were generally analyzed at a frequency of $5 \%$. Spikes for organics were generally analyzed in duplicate for every 20 samples.

Surrogate compounds were added to samples analyzed for PCBs, pesticides, PAHs and butyltins. Surrogate compounds are added to samples prior to extraction, and recoveries indicate the efficiency of the analysis. Surrogate recoveries for sediment parameters are listed in Volume 2, Appendixes $\mathrm{C}$ and $\mathrm{D}$ and for tissue parameters in Appendixes $\mathrm{P}$ and $\mathrm{Q}$.

Sediment SRMs for metals were PACS-1, MESS-1, and 1646 (see Section 2.4.2.). Sediment SRMs for organics were HS-1 and HS-2 for PCBs, and HS-5 for PAHs (see section 2.4.3 and 2.4.4). Tissue SRMs for metals were 1566a (see Section 2.4.2.). Results from analyses of these sediment SRMs are presented in Volume 2, Appendixes C (first analysis) and D (retest). SRMs for organic compounds in tissue were not available for this study. In addition, no SRMs were available for total organic carbon (TOC), oil and grease and petroleum hydrocarbons, total volatile solids (TVS), and grain size.

Percent recoveries of surrogates were calculated for eight sediment treatments and are reported for PAH, pesticides, metals and butyltins in Volume 2, Appendixes C (first analysis) and $D$ (retest). At least three sediment treatments were spiked and recovered for $Q A / Q C$ purposes, consistent with the Draft Implementation Manual.

All printouts and other raw data generated by MSL from analytical instruments are filed at MSL for future reference. Procedures and related data were written into the appropriate LRB. Raw data generated by offsite analytical facilities, for example ARI or AmTest, remain at those facilities, but can be made available for inspection.

\subsubsection{Toxicological Testing QA/OC Procedures}

Test organisms were handled carefully during collection and transfer to test containers. Organisms shipped to MSL were gradually equilibrated to ambient surroundings, and kept in their native sediment whenever possible. Animals were fed, if necessary, before biological testing. Information on the collecting and handling of each test species is included in Section 2.2. 
Selection of species was consistent with the Draft Implementation Manual and involved the use of juvenile forms, burrowing invertebrates, deposit feeding organisms, and a larval (planktonic) form. Representatives of all test organisms were taxonomically identified by qualified experts at MSL before use in bioassays.

During all bioassay tests, water quality checks were performed to ensure that acceptable experimental conditions were maintained. These conditions included a stable temperature $\left( \pm 2.0^{\circ} \mathrm{C}\right)$, a dissolved oxygen (DO) limit of $4.0 \mathrm{mg} / \mathrm{L}$, and $14 \mathrm{~h}$ of light per day. Salinity was allowed to vary $\pm 2.0 \%$, and $\mathrm{pH}$ was allowed to vary \pm 0.5 units within each container during the bioassay period. These limits and values are consistent with those outlined in the Draft Implementation Manual. Actual water quality data for each biological test are presented in Volume 2, Appendixes $E$ through $O$. Water quality instruments were calibrated according to the manufacturer's specification or PNL protocols. 


\subsection{RESULTS}

\subsection{GEOLOGIC DESCRIPTION}

This section describes the geology of Oakland Harbor Phase III A Project sediments based on sediment samples collected at 17 stations in June 1990. Figure 2.1 shows the study area and locations of sampling stations in the Oakland Inner and Outer Harbor and Oakland Inner Harbor turning basin. Prior to compositing core segments at MSL, the cores were geologically described according to ASTM Procedure D2488-84, Standard Practice for Description and Identification of Soils (Visual-Manual Procedure) (ASTM 1989). The following sediment characteristics were observed:

- dilatancy of silt/clay

- toughness of silt/clay

- plasticity of silt/clay

- sediment type (t.e., engineering classification)

- color

- consistency (i.e., firmness)

- cementation

- sedimentary structure

- reaction with hydrochloric acid

- maximum particle size

- odor.

Other diagnostic features, such as the presence of root traces, mollusk shells and/or related detritus, were also noted. A detailed description of materials and methods used for describing the cores is provided in Appendix B. A total of 49 cores (approximately $450 \mathrm{ft}$ ) from 17 stations was used for geologic characterization of the study area. Three separate geologic units were identified in the sampling area: Older Bay Mud (OBM), Sand Deposits, and Younger Bay Mud (YBM) (USACE 1975). Four cross sections were identified in the Inner Oakland Harbor study area, and all are depicted in Figure 3.1. Each of these are described in more detail in the following sections.

\subsubsection{Qlder Bay Mud Unit}

The oldest geologic unit is the OBM, consisting of deposits ranging from loose sands to hard, stiff, silty clays. Deposition of OBM probably occurred during the last glacial period when sea level resided as much as $335 \mathrm{ft}$ below its present level. Glacial periods have occurred throughout the Pleistocene Era at approximately 100,000-yr intervals over the last one million yr. The last glacial period began about $125,000 \mathrm{yr}$ ago and ended 12,000 yr ago (CLIMAP 1984). It is 


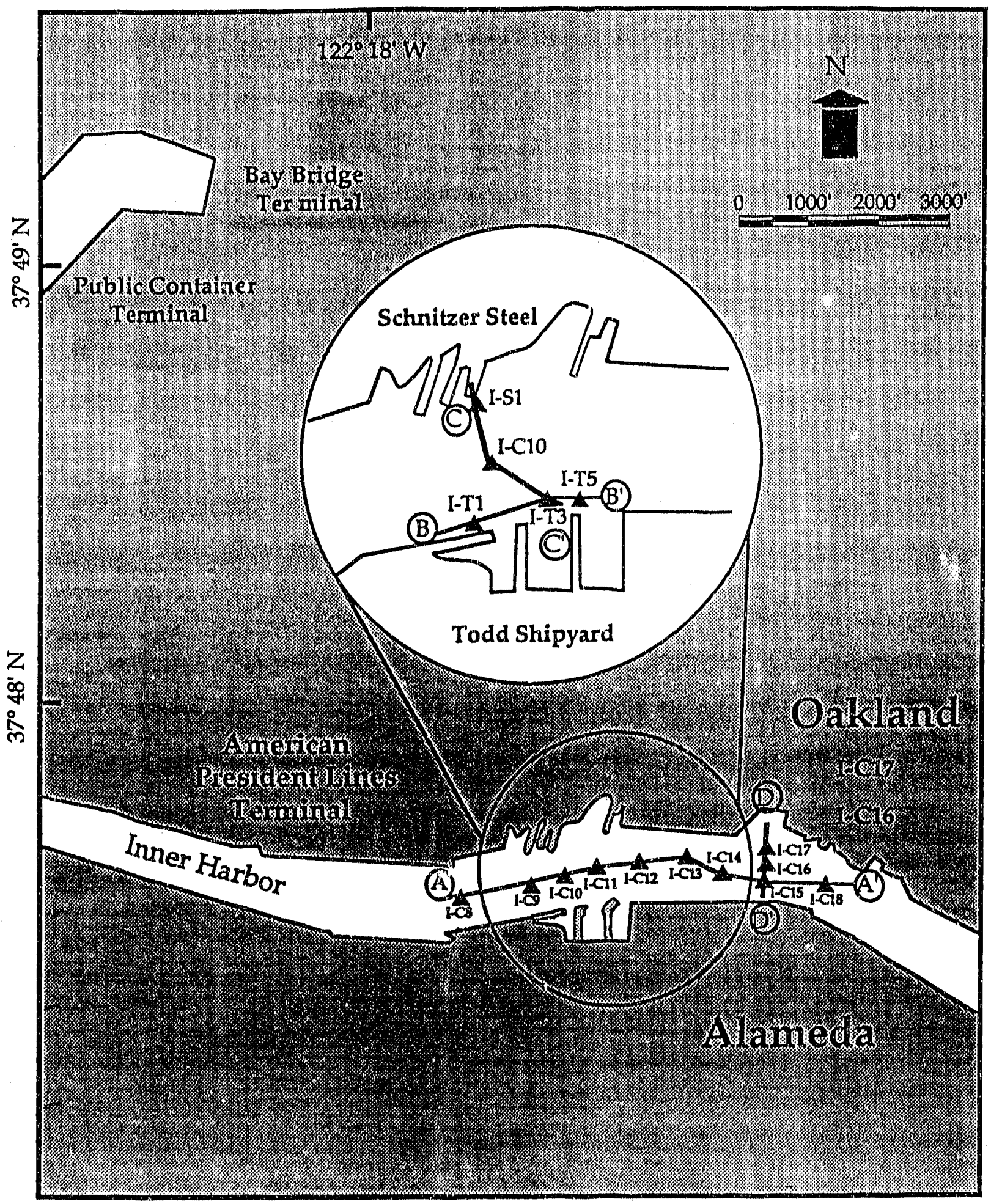

EIGURE 3.1. Positions of Cross Sections A Through D Located Within the Inner Harbor Turning Basin

PHASE III A 
likely that most of the OBM was deposited at this time; however, some of the OBM unit may have formed during previous glacial and interglacial periods. The top of the OBM appears to be an erosional surface, but previous dredging events may also have modified the surface. This unevenness is depicted in the cross sections.

The OBM unit is distinguished primarily by two factors: 1) its firm to hard consistency and 2) its color, particularly in the terrestrial sediments, which consist of various shades of red, yellow, and brown. These colors are found in an oxidizing environment associated with deposition by ancient rivers and streams flowing westward toward the Pacific Ocean. The presence of deeply penetrating root traces is another indication of terrestrial conditions. Deposits referred to as Merritt Sands appear to contribute to the terrestrial facies of the OBM. The marine portions of the OBM, on the other hand, are drab-colored shades of olive and gray. These colors, along with the presence of whole mollusk shells, are indicative of a lower energy, more reducing, estuarine environment.

The high degree of consolidation, combined with the weathered and often bleached appearance of the OBM unit, suggests this unit is much older than the relatively recent estuarine sediments present in YBM. The highly oxidized and weathered appearance of the OBM, combined with the presence of root traces, suggests that the OBM unit underwent alteration during a period of subaerial soil development. No odors were detected in the OBM unit, possibly because its compacted nature may act as a barrier, preventing downward movement of odors associated with contamination migration.

\subsubsection{Sand Deposits}

Sand Deposits are located between the OBM and the overlying YBM. The thickness of the Sand Deposits is not uniform throughout, being generally thicker along bay margins. The Sand Deposits consist of fine grained sands mixed with considerable silt and clay. The unit is believed to comprise alluvial fans that were formed by fluviatile current action during shoreline fluctuation at the end of the Pleistocene (USACE 1975). The discontinuous nature of the Sand Deposits and their similarity to YBM make it difficult to discern between the two units. However, based on the dark color and soft consistency of the Sand Deposits, this layer will be considered part of the YBM unit for the purposes of this report.

\subsubsection{Younger Bay Mud Unit.}

The YBM unit consists mainly of soft, dark-colored sediments deposited in an estuarine environment. These deposits were laid down as the sea level rose following the last ice age, which 
ended about 12,000 yr ago (Barry 1983). The YBM unit forms a continuous blanket across the harbor bottom, except where it has been removed by dredging or submarine currents. Inland exposures of YBM are also found, indicating that sea level may have been higher in the past (USACE 1975). The YBM includes very soft to soft-silty clays and clay silts with minor amounts of organic material, fine sand, and shell fragments (USACE 1975). Soll colors range from dark gray to dark olive-gray and black. These dark colors, and the odor of rotten eggs (i.e., hydrogen sulfide), indicate chemically reducing conditions. The USACE (1975) subdivided YBM units into a Semi-Consolidated Bay Mud member overlain by a Soft Bay Mud member. Firmness of the cores from the study area generally increases with depth. This appears to be a result of compaction from overlying sediments rather than a sudden, characteristic change in consistency, which is considered the boundary between the Semi.Consolidated Bay Mud and Soft Bay Mud members (USACE 1975).

\subsubsection{Geologic Analysis}

All sediment cores used for geologic descriptions were taken from the Oakland Inner Harbor, with several cores concentrated within the Oakland Inner Harbor turning basin, as shown in Figure 3.1. The sediment within the Oakland Inner Harbor is divided into two geologic units: the firm to hard terrestrial and marine deposits of the OBM, and the dark-colored, soft, marine deposits of the YBM. The relationship between the OBM and the YBM is graphically represented in the twodimensional cross sections shown in Figures 3.2 through 3.5. All four cross sections represent an area concentrated within the Inner Harbor turning basin. Two cross sections, A - $\mathrm{A}^{\prime}$ and B - B', (Figures 3.2 and 3.3) trend west to east, parallel to the channel axis. Cross sections $C-C^{\prime}$ and $D$ $D^{\prime}$ (Figures 3.4 and 3.5) trend cross channel. The contact between the OBM and the YBM units, which is distinguished by consistency and color, is represented by a bold, dashed line. The YBM unit in the Inner Harbor turning basin consists almost entirely of silty clay, with an occasional interfingering of sand or a silty-sand lens. These lenses may be related to an influx of sedimentladen water, perhaps associated with runoff following severe storms. Very few mollusks were found within this portion of the Inner Harbor turning basin. The thickness of the YBM varies within the turning basin. The thickest deposits (less than $8 \mathrm{ft}$ ) occur along the channel edges on the northeast and southwest portions of the turning basin, while the thinnest deposits are in the center of the channel. Deposits of YBM in the center of the channel within the turning basin range from less than $2 \mathrm{ft}$ to $4.5 \mathrm{ft}$.

The OBM within the turning basin consists predominately of the oxidized, yellow to brown terrestrial sand facies known as the Merritt Sands. These deposits are often consolidated with a 
Depth Below Mean Lower Low Water (MLLW)

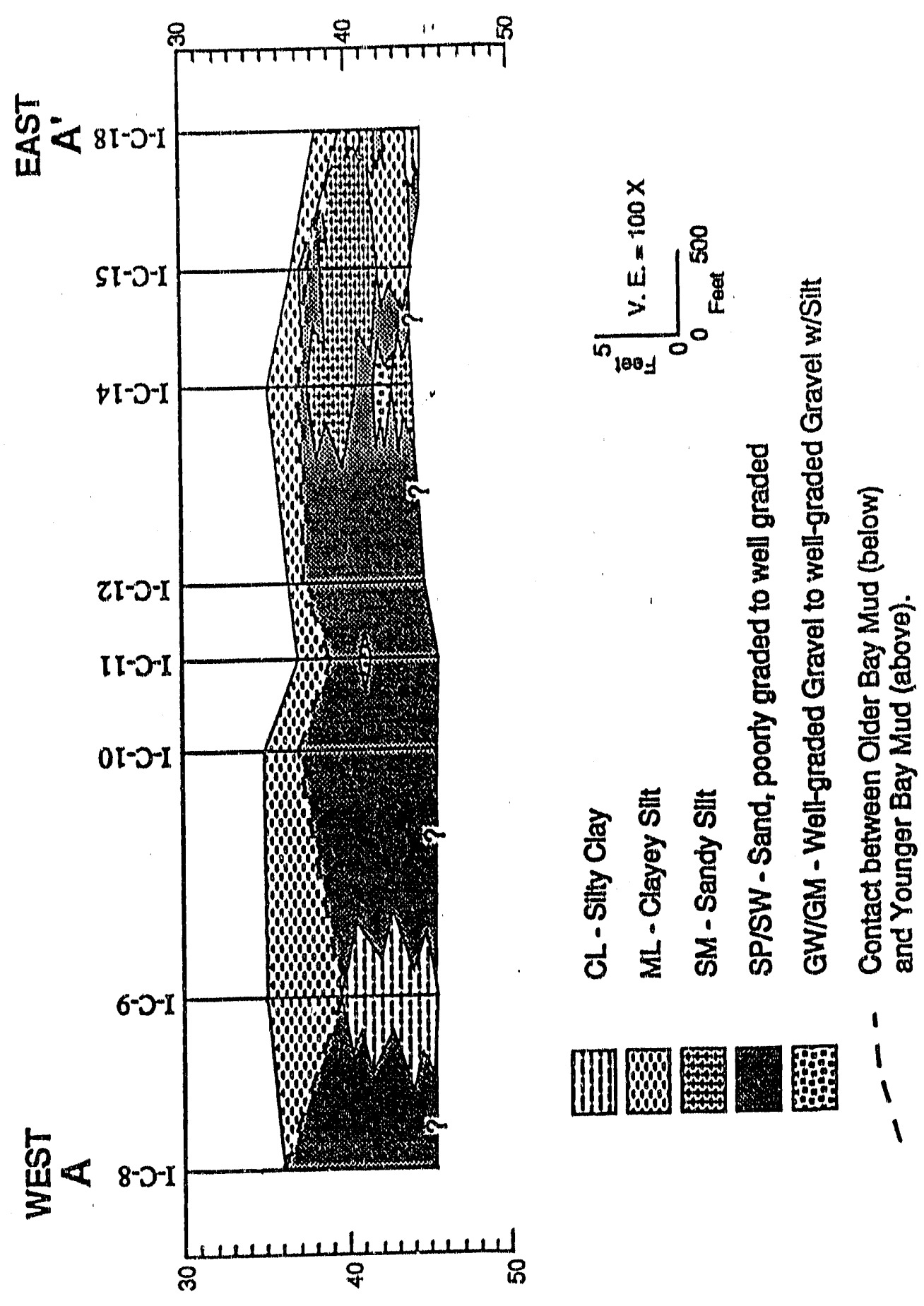

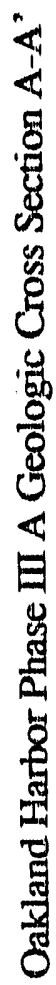

㓓

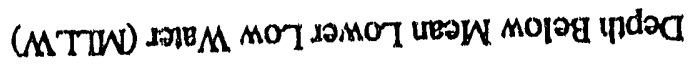

PHASEIIIA 


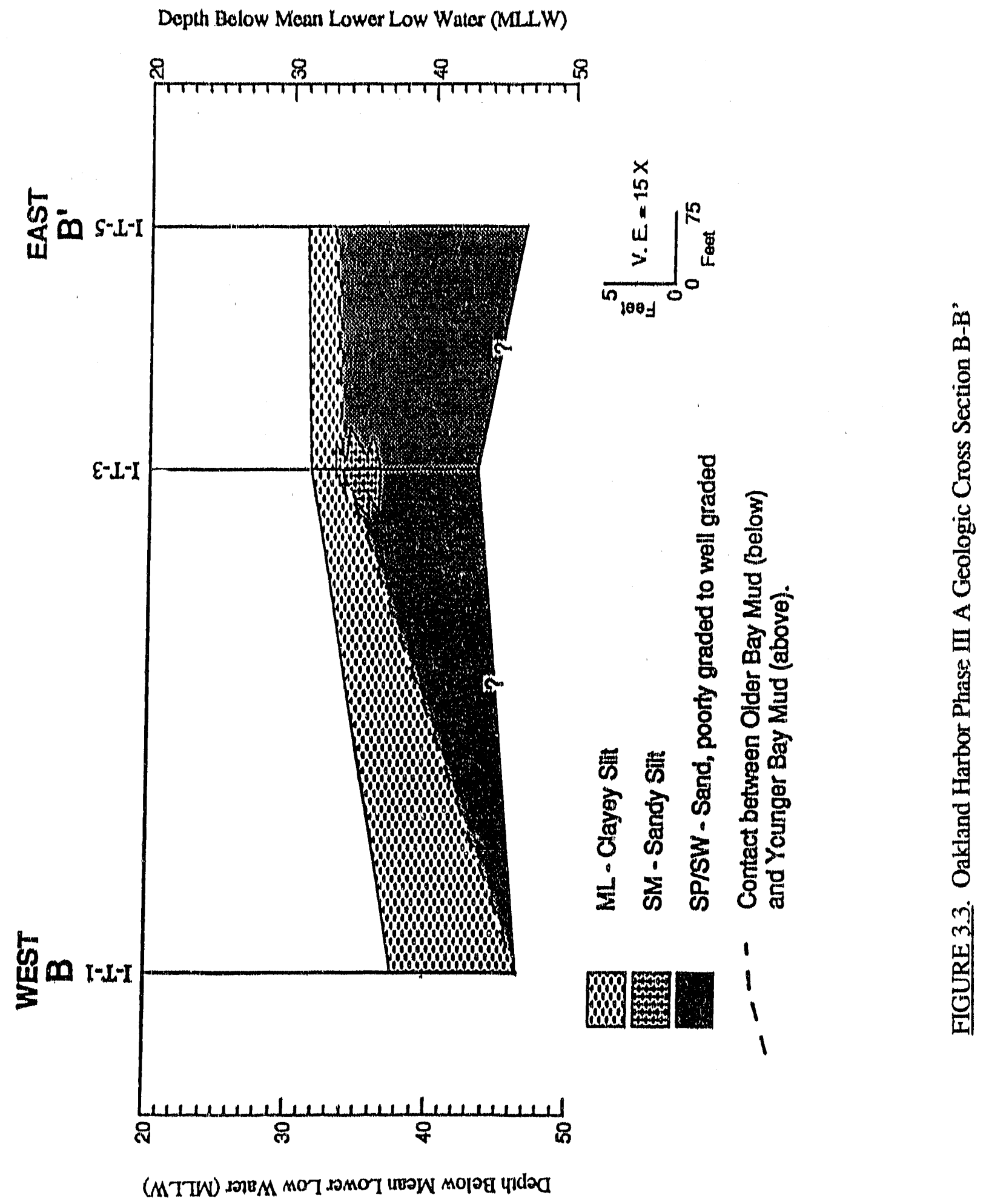

BHASE IILA 


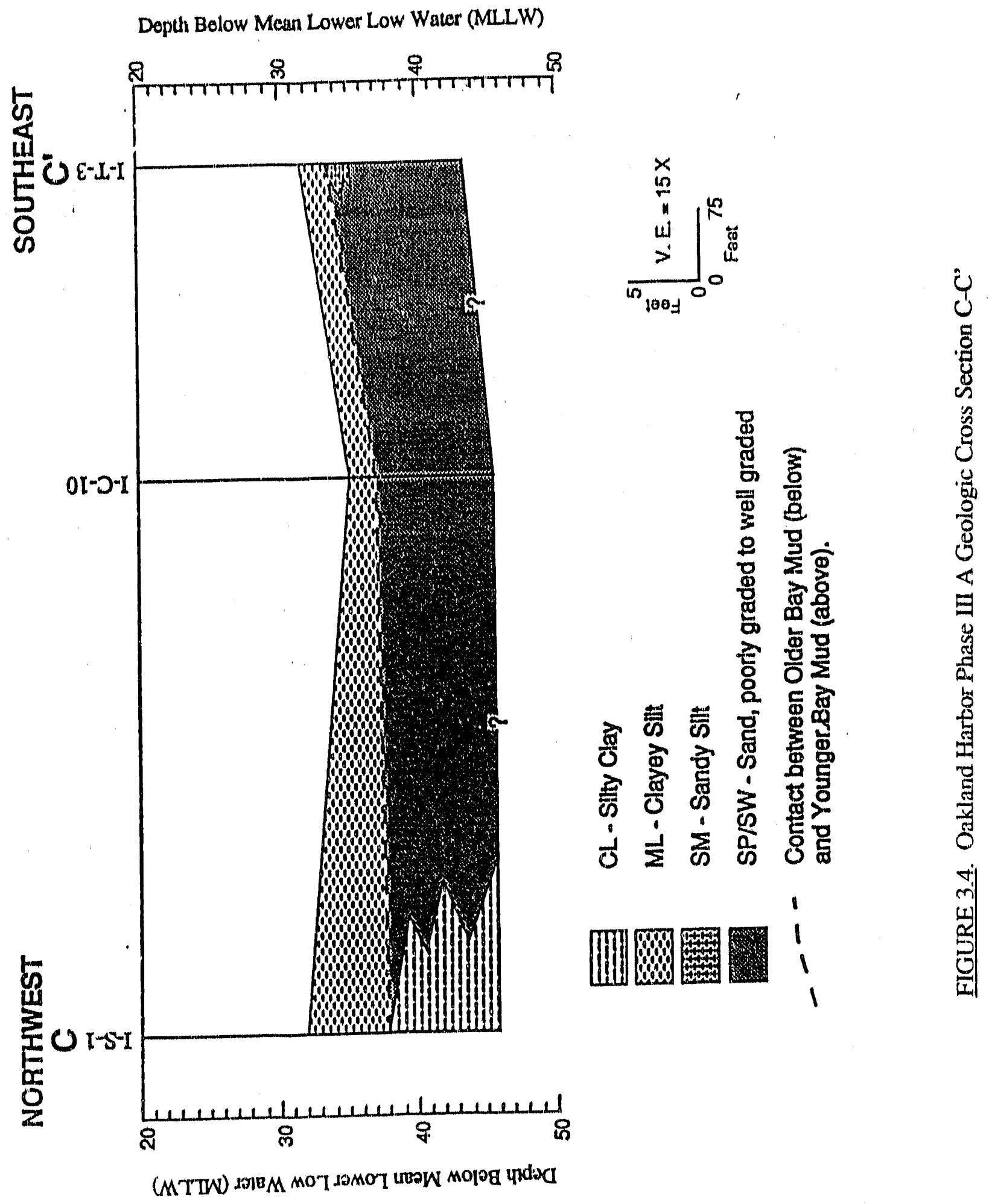

PHASE LILA 
Depth Below Mean Lower Low Water (MLLW)

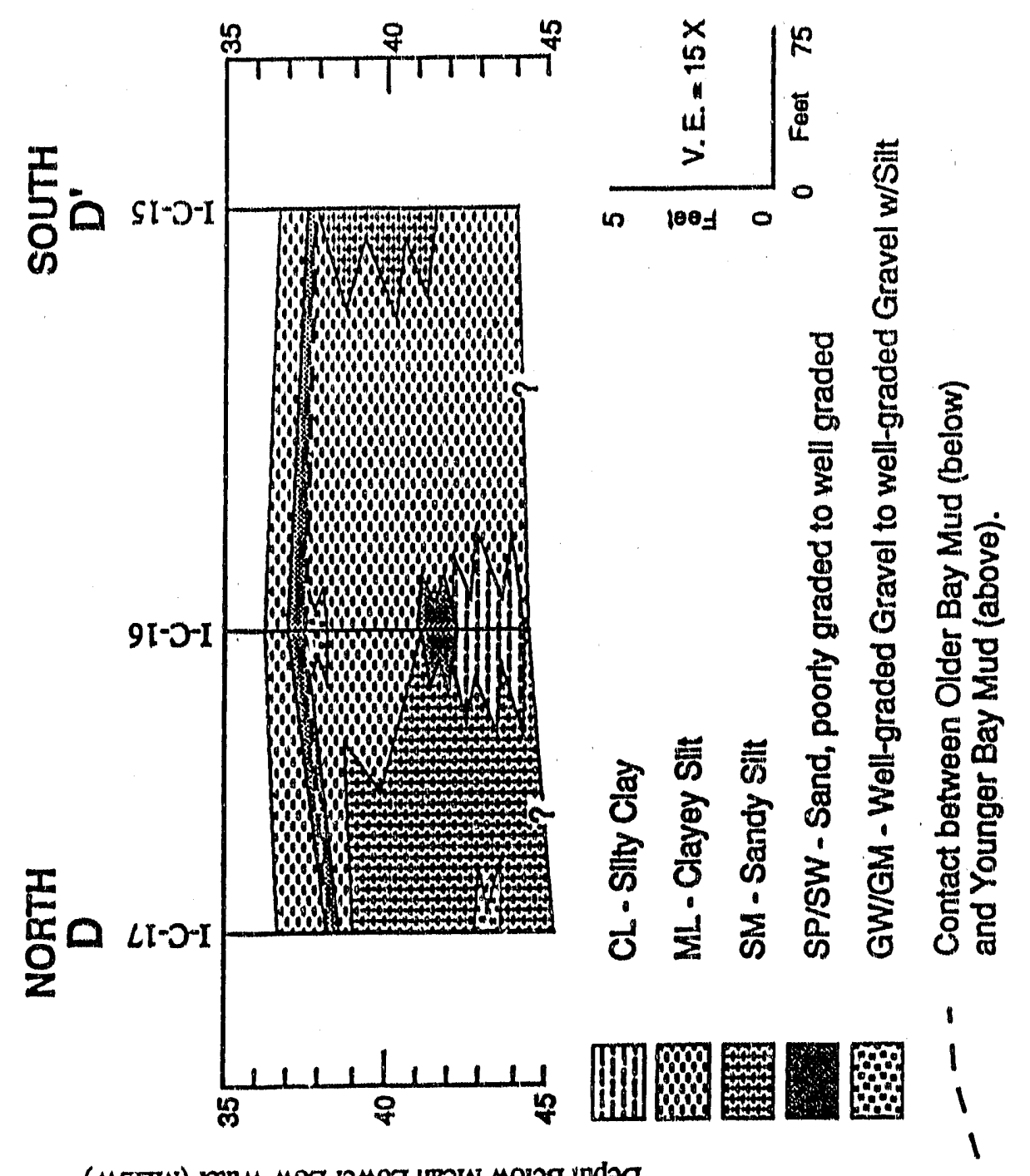

을

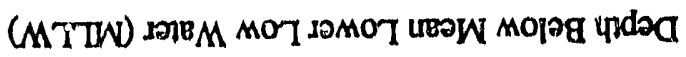


well to poorly graded consistency and commonly exhibit iron staining. In the central and eastern portions of the turning basin, several cores contained clay ripup clasts, scattered pebbles, and shell fragments, suggesting sudden, periodic disturbances or influxes of water. Cores located in the eastern portion of the turning basin contained fine-grained deposits with a clay-silt to sandy-silt consistency, usually associated with the OBM marine facies. The sediments were of a firm to hard consistency and the colors were drab shades of olive to gray, indicating a reducing environment. The cross sections in Figures 3.2 through 3.5 also show the interfingering nature of the terrestrial and marine facies of the OBM. This fingering is likely the result of the proximity of the turning basin to a deltaic sedimentary environment during glacial times. The interfingering facies and isolated lenses can be attributed to migrating delta fronts, sea-level fluctuations, and/or sudden, periodic influxes of water during storms. Sediment cores in the western portion of the turning basin are primarily OBM terrestrial sands overlain by approximately $1 \mathrm{ft}$ of softer YBM silts that were lost during sampling.

\subsection{RESULTS OF PHYSICAL AND CHEMICAL ANALYSES ON SEDIMENTS}

The following sections present the results of physical and chemical analyses conducted on the Oakland Phase III A sediment samples. Analyses were performed using conventional measurements and analytical chemistry. All data meet $\mathrm{QC}$ requirements, which are presented in detail in Volume 2, Appendix $\mathrm{C}$.

\subsubsection{Conventional Measurements for Sediment Analysis}

Conventional measurements used for sediment analysis include grain size, TOC, TVS, oil and grease, and total TPH. Each of these measurements are discussed in the following paragraphs.

Results of sediment grain size analysis are summarized in Table 3.1, and presented graphically in Figure 3.6. Complete results of grain size analysis are provided in Volume 2, Appendix C, Table C.25. Grain size results for each sample are reported as percentages of gravel, sand, silt, and clay. The Oakland Inner Harbor channel and turning basin sediment was predominantly $\geq$ $40 \%$ ) sand sized or larger. This was not the case for samples collected at stations I-C5, I-C9, I-S1, and I-T1, however, which were predominantly ( $\geq 34 \%$ ) clay or finer grain sizes. Control sediments were predominantly sand sized or larger. For the Phase III A bioassays, sediment treatment from R-PC, R-AM, and R-AC were used as reference treatments representing the coarsergrained sediments in Oakland Harbor. Sediment treatments from R-BF, R-OS, and R-PF were used as reference treatments representing the finer-grained sediments. 
TABLE 3.1. Summary of Results of Grain Size Analysis of Oakland Phase III A Sediment Samples

Sediment

Treatment

AC-1

AC-3

IC- 4

IC-5

IC-7

IC-8

IC-9

IC- 10

IC-11

IC- 12

IC-14

IC- 15

IC-16

IC-17

IC-18

I-S1

I-T1

I-T3

I-T5

R-AC

R-AM

R-BF

R-OS

R-PC

R-PF

C-SB

C-WB

C-NE

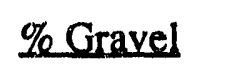

1.09

0.00

0.00

0.00

0.00

0.00

0.00

0.35

0.00

0.00

8.66

0.25

0.00

0.00

0.52

0.11

0.11

0.05

0.22

0.00

2.73

0.00

6.77

0.00

0.00

0.00

0.00

0.09

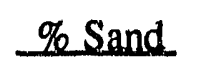

63.80

46.94

90.00

35.77

91.22

93.54

4.92

92.69

91.85

97.08

52.47

60.71

56.89

51.30

40.90

1.98

2.24

87.11

83.80

85.51

92.41

29.23

48.24

70.02

55.30

58.66

94.00

87.20
\% Silt

15.45

19.15

2.28

29.48

6.53

0.94

38.35

2.52

1.79

1.54

23.48

24.57

21.99

28.65

32.50

30.16

36.27

5.55

4.58

6.65

1.06

15.90

25.67

21.57

33.91

23.69

1.83

4.98
\% Clay

19.66

33.92

7.73

34.73

2.27

5.52

56.73

4.44

6.38

1.37

15.40

13.93

21.13

20.06

26.08

67.77

61.39

7.29

11.40

7.84

3.80

54.88

19.31

8.39

10.79

17.66

4.16

7.72

Results of TOC analysis of Oakland Harbor Phase III A sediment treatments are presented graphically in Figure 3.7. The TOC data are provided in Volume 2, Appendix C, Table C.20. The TOC concentrations for the 19 Oakland Harbor sediment creatments ranged from $0.01 \%$ to $1.22 \%$ dry weight. In general, lower TOC values were found in the coarse-grained sediment, and TOC values were inversely related to the percentage of coarse-grained sediment. Figure 3.8 shows a linear regression representing this inverse relationship between sediment grain size and TOr. Note that sediment composites from I-C5, I-C9, I-S1 and I-T1 follow this trend. Sediment treatments I-S1 and I-T1 had the highest TOC levels of $0.92 \%$ and $1.22 \%$ dry weight, respectively, and the lowest percentages of coarse-grained fractions. The TOC concentrations for the six reference sediment treatments and three control sediment treatments ranged from $0.03 \%$ to $0.91 \%$; treatments $\mathrm{C}-\mathrm{NE}$ and $\mathrm{C}-\mathrm{SB}$ had the highest TOC levels in this group $-0.91 \%$ and $0.88 \%$, respectively. The 


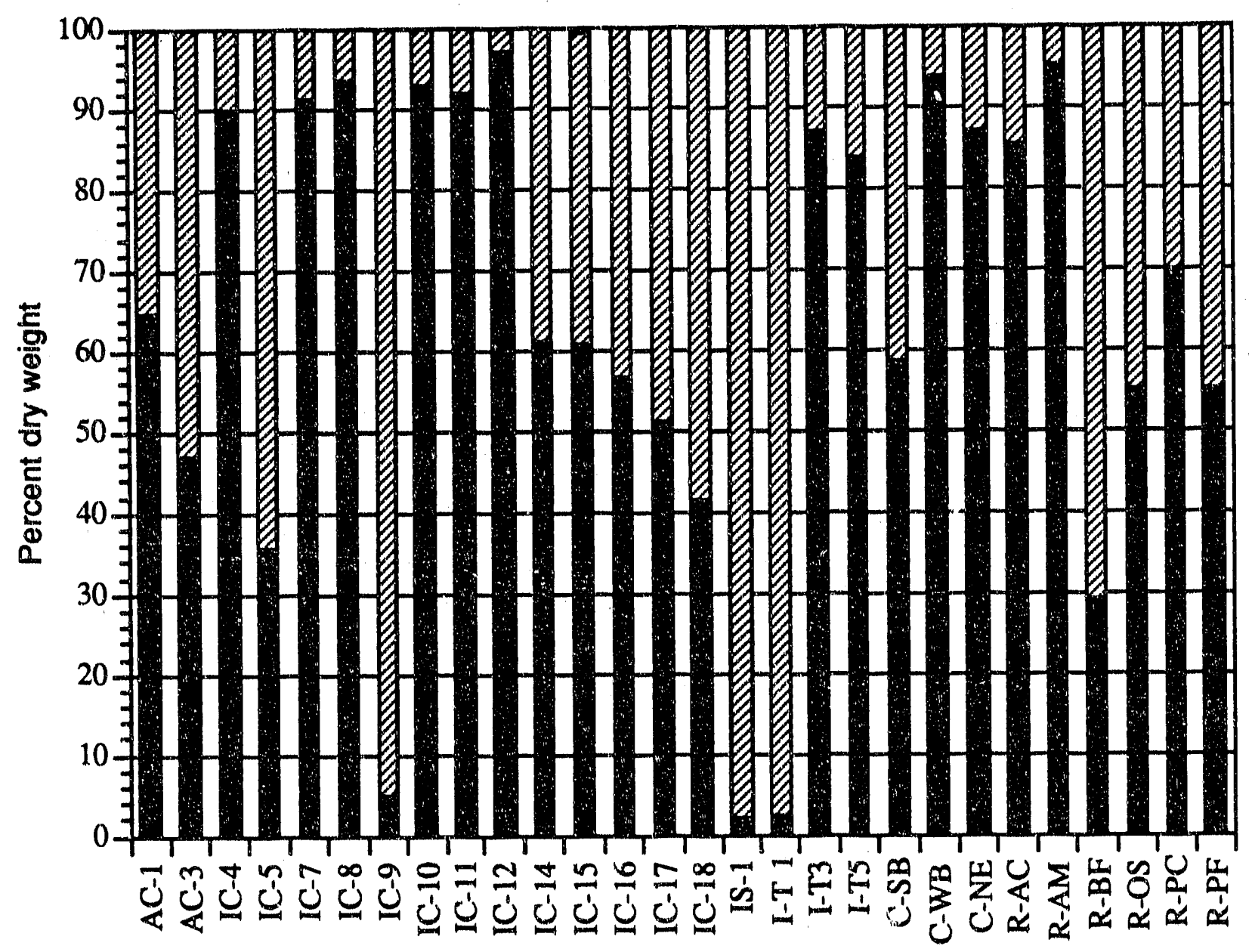

Sediment Treatment

E. FINE SED COARSE SED

FIGURE 3.6. Results of Sediment Grain Size Analysis of Oakland Phase III A Sediment Treatments (Coarse Sediments are Composed of Sand and Gravel; Fine Sediments are Composed of Silt and Clay).

percentage of TOC in the remaining Oakland Harbor Phase III A sediment treatments also fell within the range similar to that of the coarse-grained reference (R-AC and R-AM) and control sediments (C-WB).

Results of TVS analysis are presented graphically in Figure 3.9. The TVS data are provided in Volume 2, Appendix C, Table C.22. The TVS content of the 19 sediment treatments from Oakland Inner and Outer Harbors ranged from $1.2 \%$ to $10.08 \%$. Sediment treatment I-T1 had the highest percentage of TVS (10.08\%), followed by I-S1 (7.57\%), I-C9 (7.00\%), and I-C5 $(5.70 \%)$. The reference and control sediments, C-SB, R-BF, and R-OS, had TVS values that 


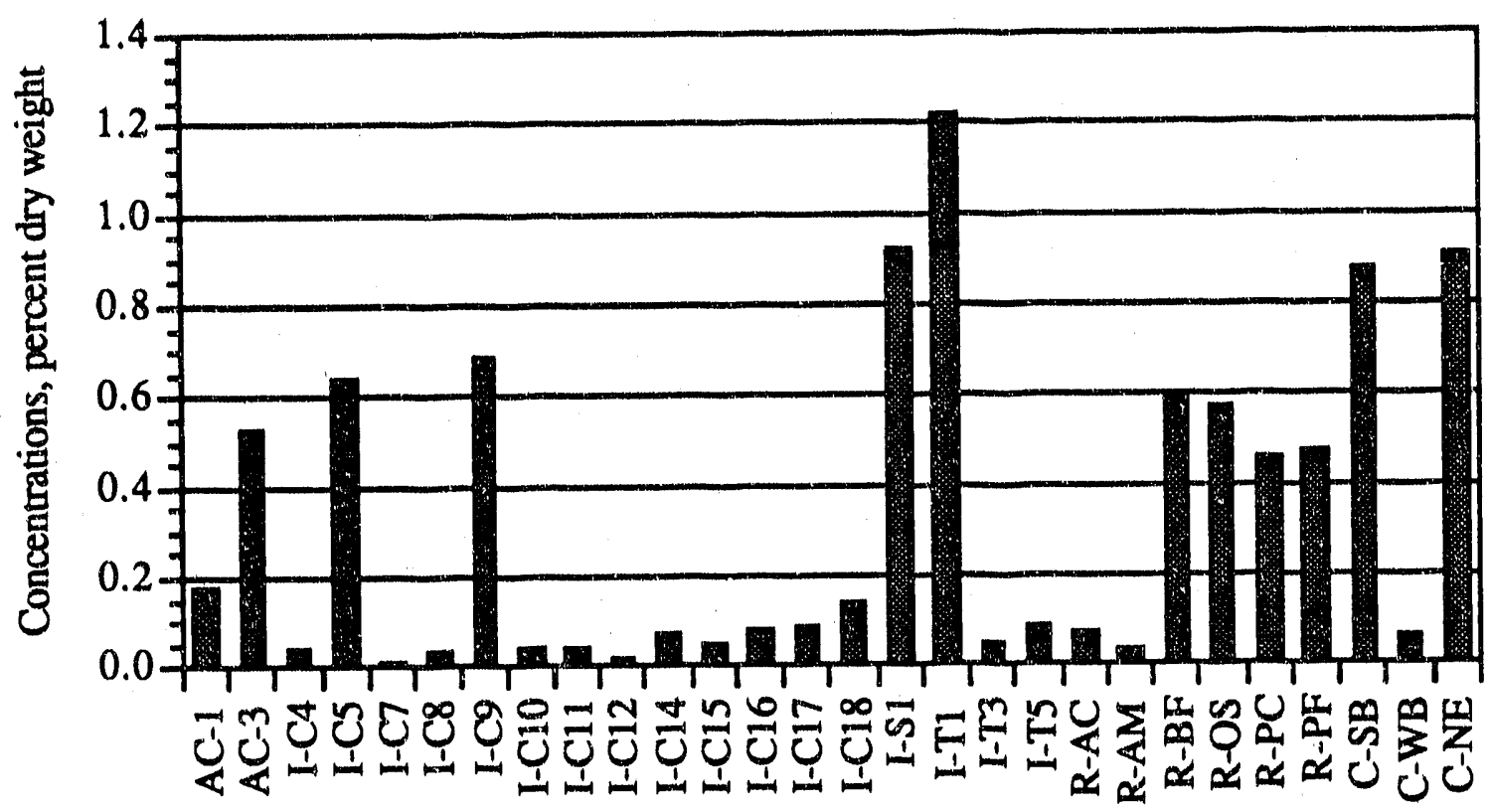

Sediment Treatment

FIGURE 3.7. Concentrations of TOC Found in Oakland Phase III A Sediment Treatments

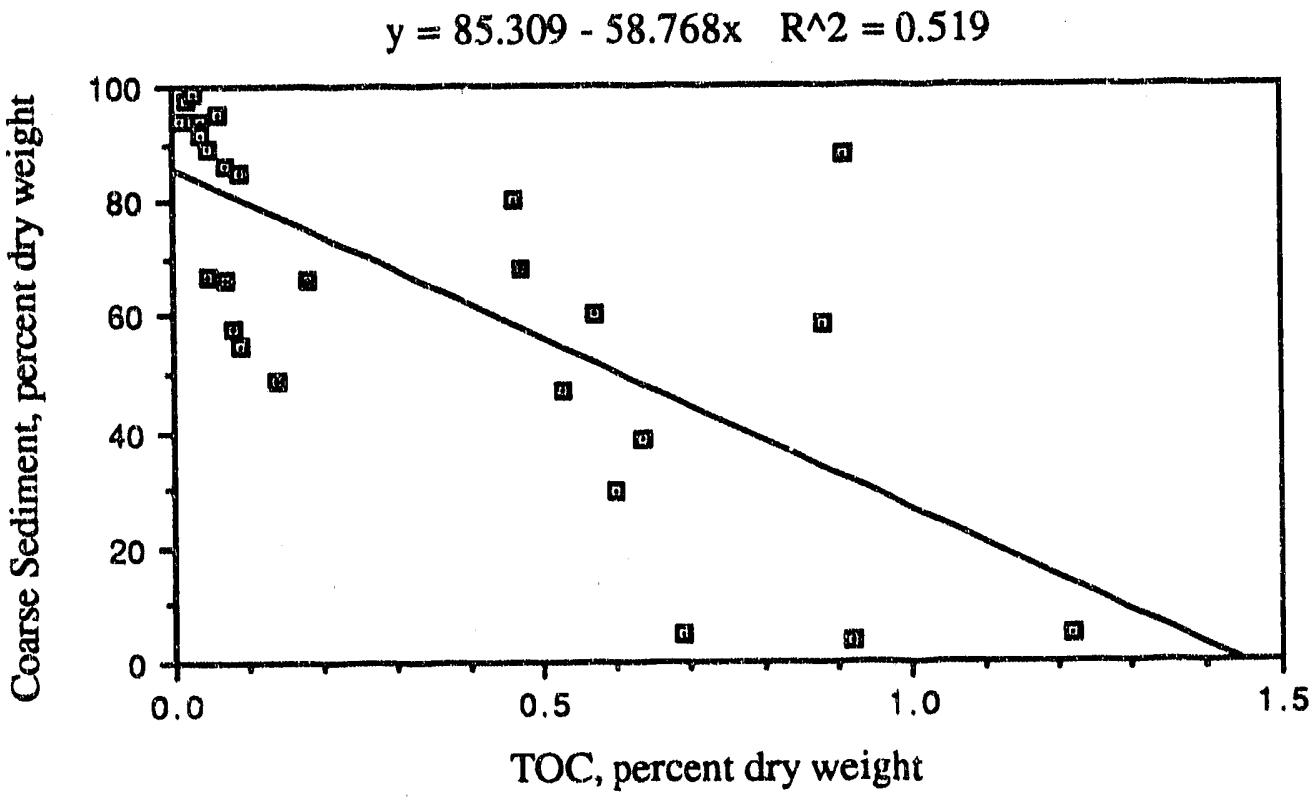

FIGURE 3.8. Linear Regression Showing the Relationship Between Sediment Grain Size and TOC in Oakland Phase III A Sediment Treatments 


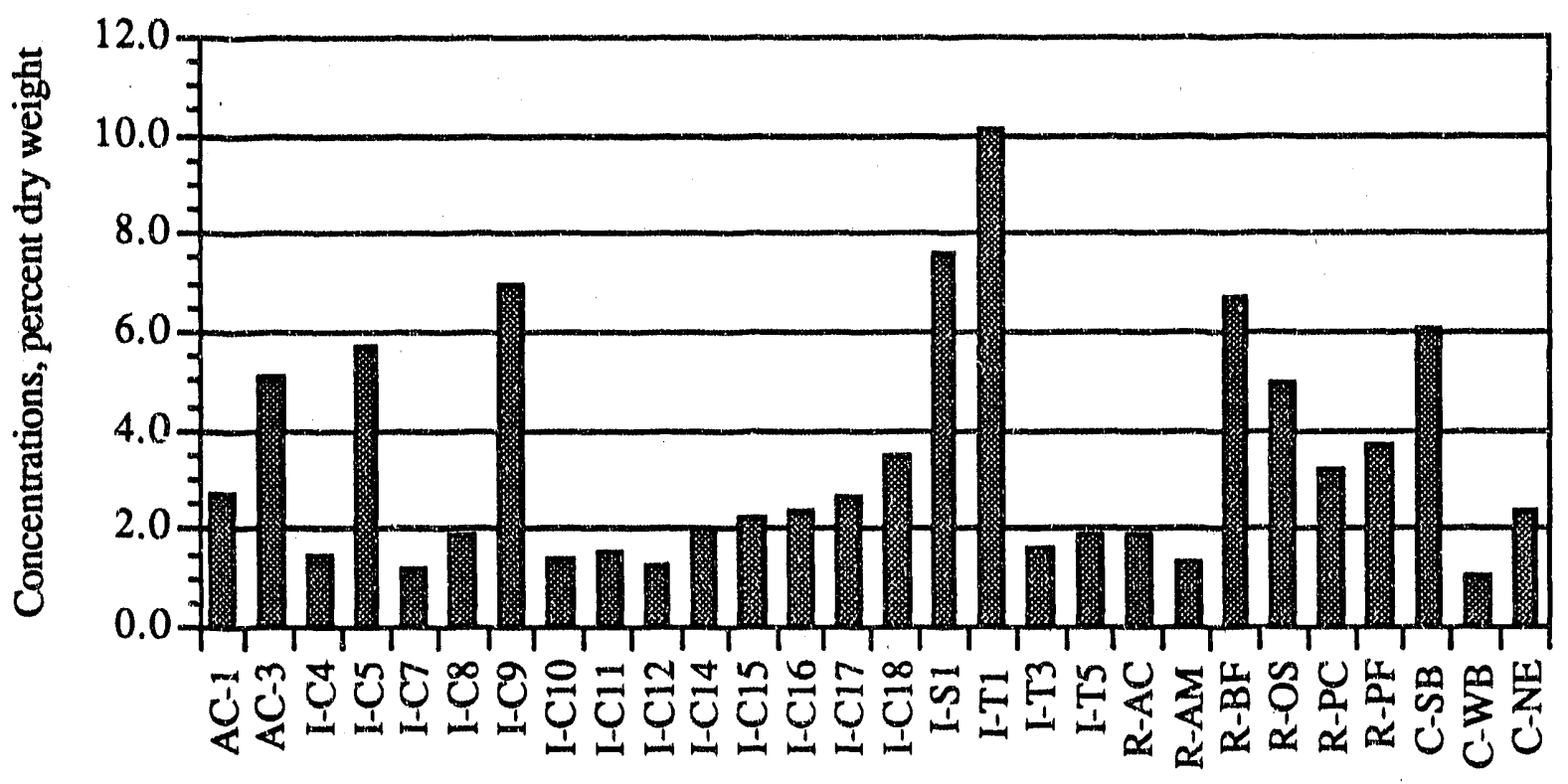

Sediment Treatment

EIGURE 3.9. Concentrations of TVS Found in Oakland Phase III A Sediment Treatments

approached the elevated concentrations that were found in the sediment treatments. With the exception of these samples, the TVS content of the remaining Oakland Inner and Outer Harbor samples was similar to that of the remaining reference and control treatments. The TVS content of these remaining sediment treatments ranged from $1.08 \%$ at $\mathrm{C}-\mathrm{WB}$ to $6.67 \%$ at $\mathrm{R}-\mathrm{BF}$.

Figure 3.10 shows a linear regression representing the relationship between TOC and TVS. Unlike the inverse relationship demonstrated by grain size and TOC, TVS and TOC show a linear relationship. In general, those sediment treatments having the highest percentage of TVS also have the highest percentage of TOC. Reference and control sediment treatments tended to fall below the line, closer to the horizontal axis. This trend suggests that a lesser amount of the TVS content of these treatments is TOC.

The analysis results for oil and grease are presented graphically in Figure 3.11. Oil and grease data are provided in Volume 2, Appendix C, Table C.18. Oil and grease concentrations ranged from undetected to $178.35 \mathrm{mg} / \mathrm{kg}$. Sediment treatment I-T1 had the highest oil and grease concentration (178.35 mg/kg), followed by I-C5 (102.93 mg/kg), and I-C12 (63.71 mg/kg). Concentrations in these treatments exceeded the highest values for oil and grease found at reference and control treatments C-SB $(58.93 \mathrm{mg} / \mathrm{kg})$ and C-NE $(23.52 \mathrm{mg} / \mathrm{kg})$, as well as oil and grease 


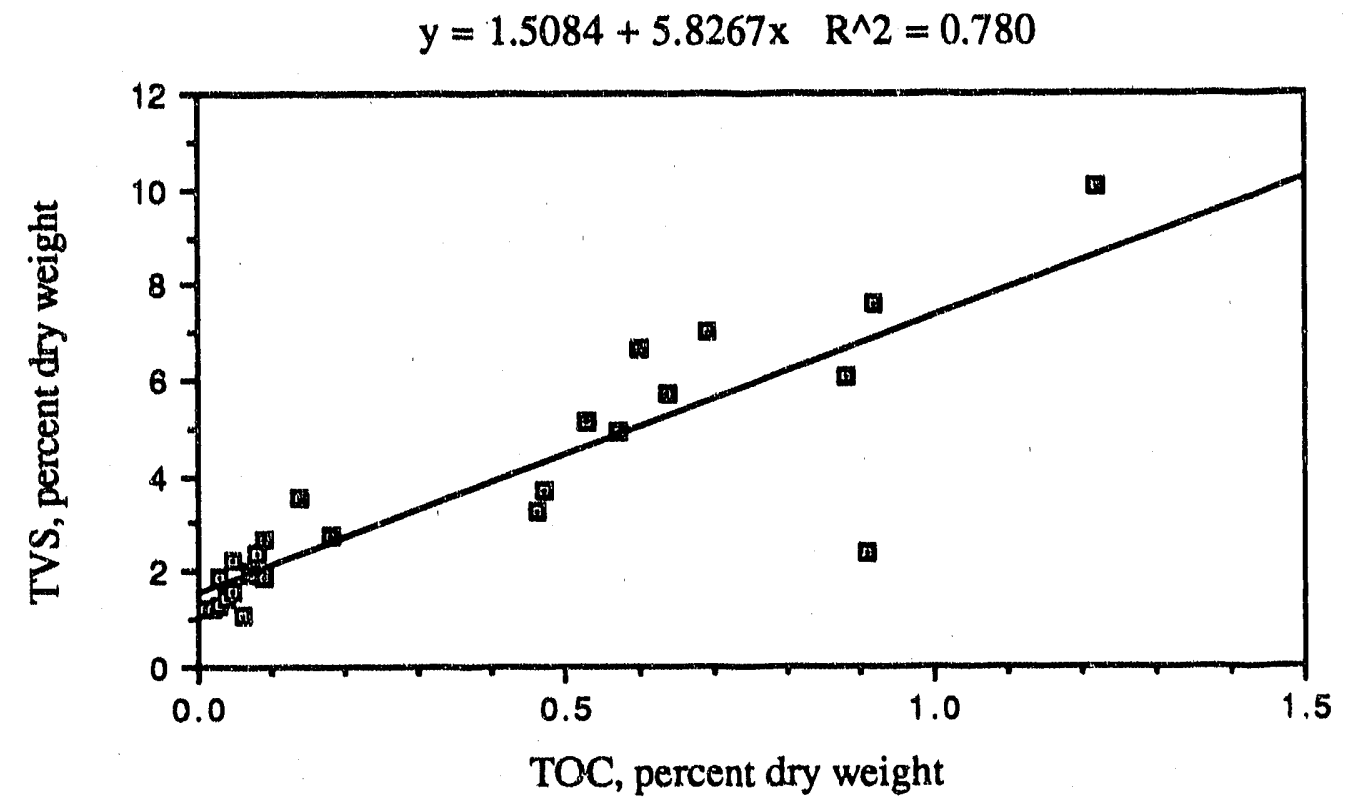

FIGURE 3,10. Linear Regression Showing the Relationship Between TOC and TVS in Oakland Phase III A Sediment Treatments

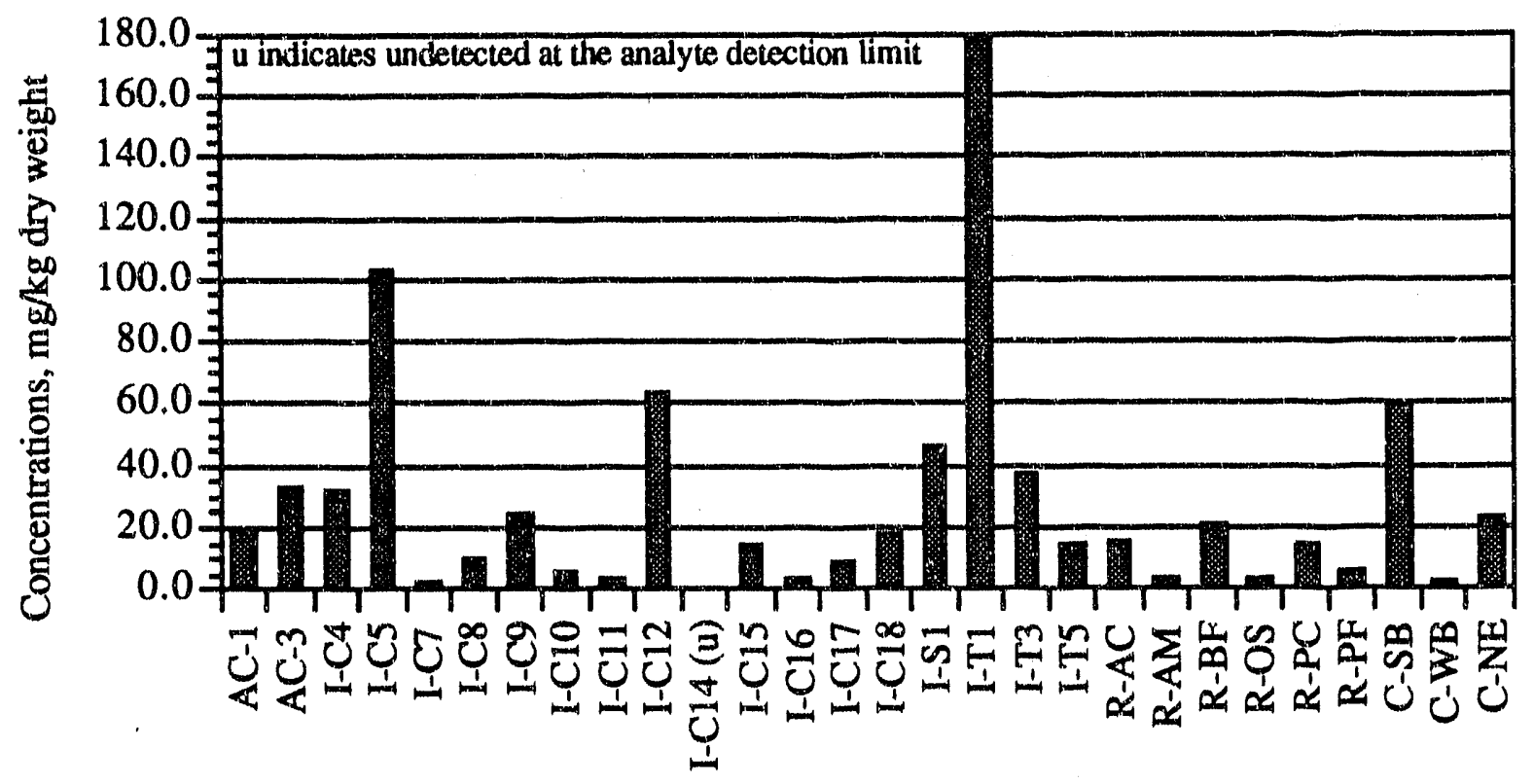

Sediment Treatment

EIGURE 3.11. Concentrations of Oil and Grease Found in Oakland Phase III A Sediment Treatments 
concentrations found in the remaining Oakland Phase III A sediment treatments that were dominated by sand and had lower concentrations of TOC.

The analysis results for TPH are presented graphically in Figure 3.12. The TPH data are provided in Volume 2, Appendix C, Table C.18. Concentrations of TPH were highest in three sediment treatments: I-T1 (159.61 mg/kg), I-C5 $(80.46 \mathrm{mg} / \mathrm{kg})$, and C-SB, $(43.60 \mathrm{mg} / \mathrm{kg})$. The relatively high values of TPH and oil and grease found in these treatments, particularly I-C5 and C-SB, suggest that these stations should be more closely examined for PAHs in sediment and in corresponding tissue samples.

Figure 3.13 shows a linear regression representing the positive correlation between TPH and oil and grease. (Note that the coefficient of determination is high, 0.923.) Those treatments having the highest percentage of oil and grease also have the highest percentage of TPH.

Reference and control treatments tended to fall below the line, close to the horizontal axis, showing a low TPH content, which suggests the oil and grease contained in these sediments are not of petroleum origin.

Figure 3.14 shows a linear regression representing the relationship between TPH and TOC. For most of the sediment treatments other than reference and control treatments, generally, both TPH and TOC are low. The reference and control treatments tend to fall below the line, having a low TPH and a higher TOC value, suggesting that the organic carbon found at these sites does not have a high petroleum content. Two treatments were exceptions to these trends: I-C5 and I-T1 have both high TPH and high TOC values, suggesting that the organic carbon found in these sediments is of a petroleum-based origin.

\subsubsection{Metals}

Ten metals were measured in sediment composites from Oakland Inner and Outer Harbors. Data from all metals analyses, reported in $\mathrm{mg} / \mathrm{kg}(\mathrm{ppm})$ dry weight, are provided in Volume 2, Appendix C, Table C.12. Because these metals are ubiquitous in nature, the metal concentration for each treatment, including the six reference and three control sediments, will be compared to a typical shale sediment (Krauskopf 1967).

Silver $(\mathrm{Ag})$ concentrations found in each sediment treatment and in typical shale soil are presented graphically in Figure 3.15. Silver concentrations for each of the 19 sediment composites ranged from $0.038 \mathrm{mg} / \mathrm{kg}$ (I-C7) to $0.629 \mathrm{mg} / \mathrm{kg}$ (I-T1). Concentrations of $\mathrm{Ag}$ found in the six reference and three control treatments ranged from $0.050 \mathrm{mg} / \mathrm{kg}$ (C-NE) to $0.391 \mathrm{mg} / \mathrm{kg}$ (R-BF). All sediment treatments except I-T1 had Ag concentrations that were less than those found in the 


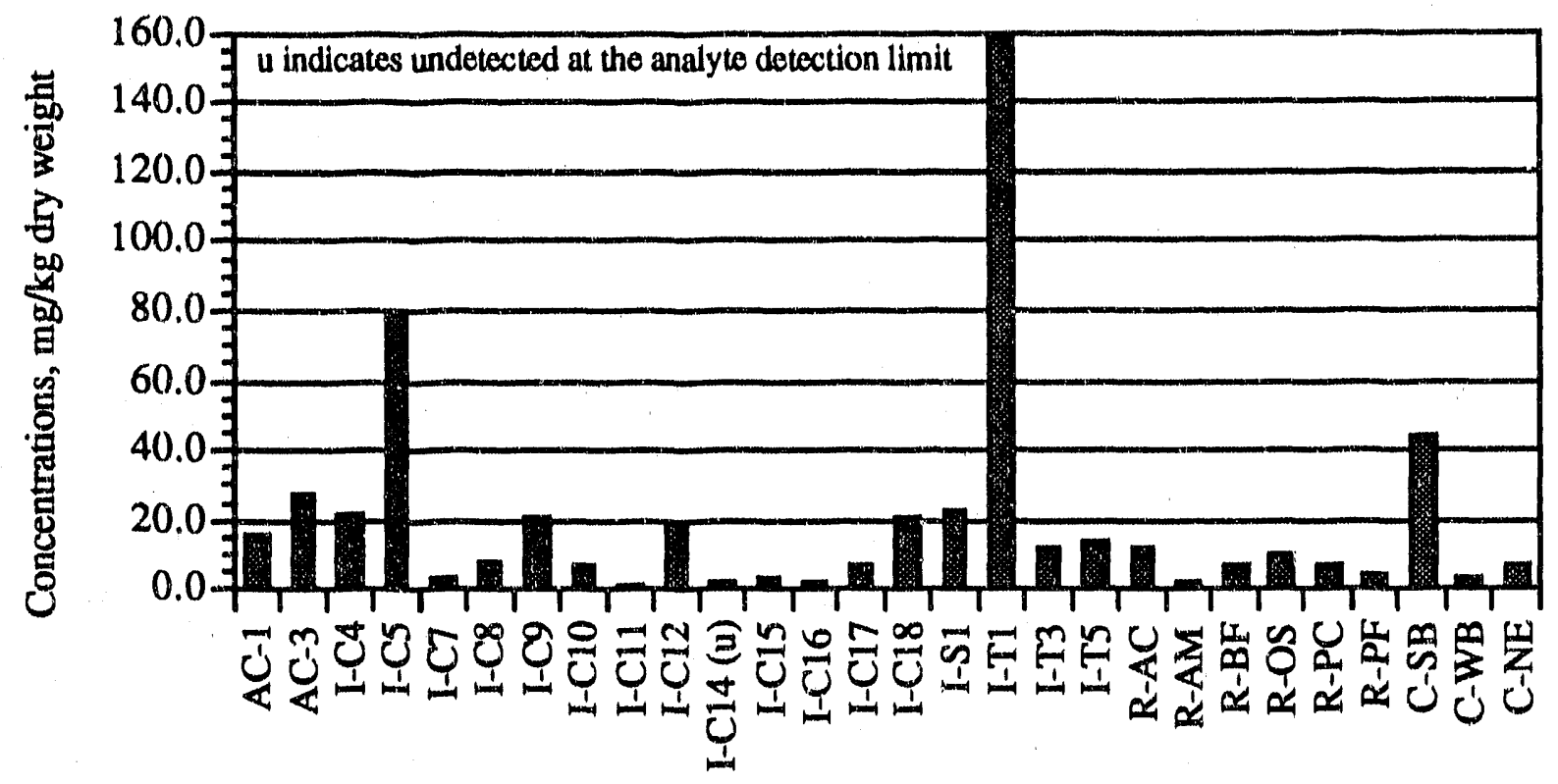

Sediment Treatment

ELGURE 3.12. Concentrations of TPH Found in Oakland Phase III A Sediment Treatments

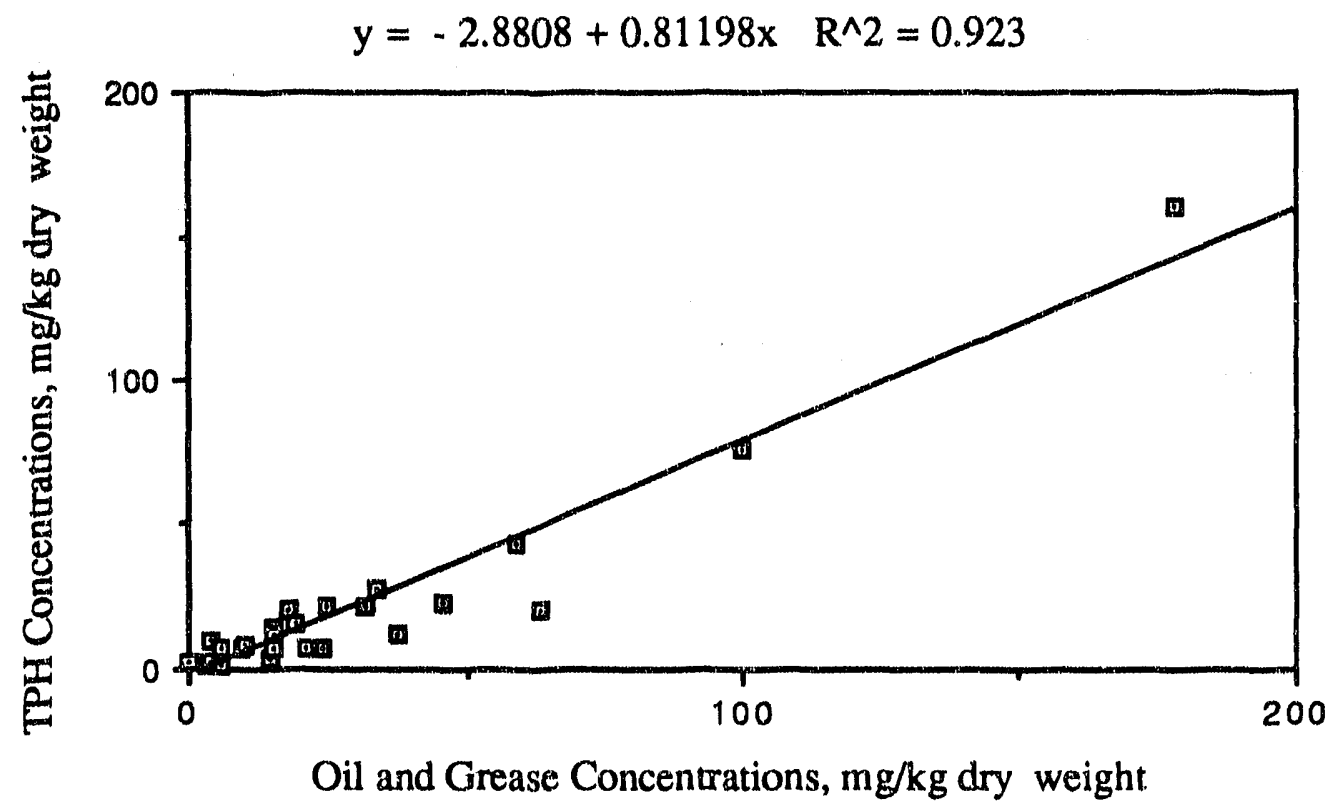

FIGURE 3.13. Linear Regression Showing the Relationship Between Oil and Grease and TPH in Oakland Phase III A Sediment Treatments 


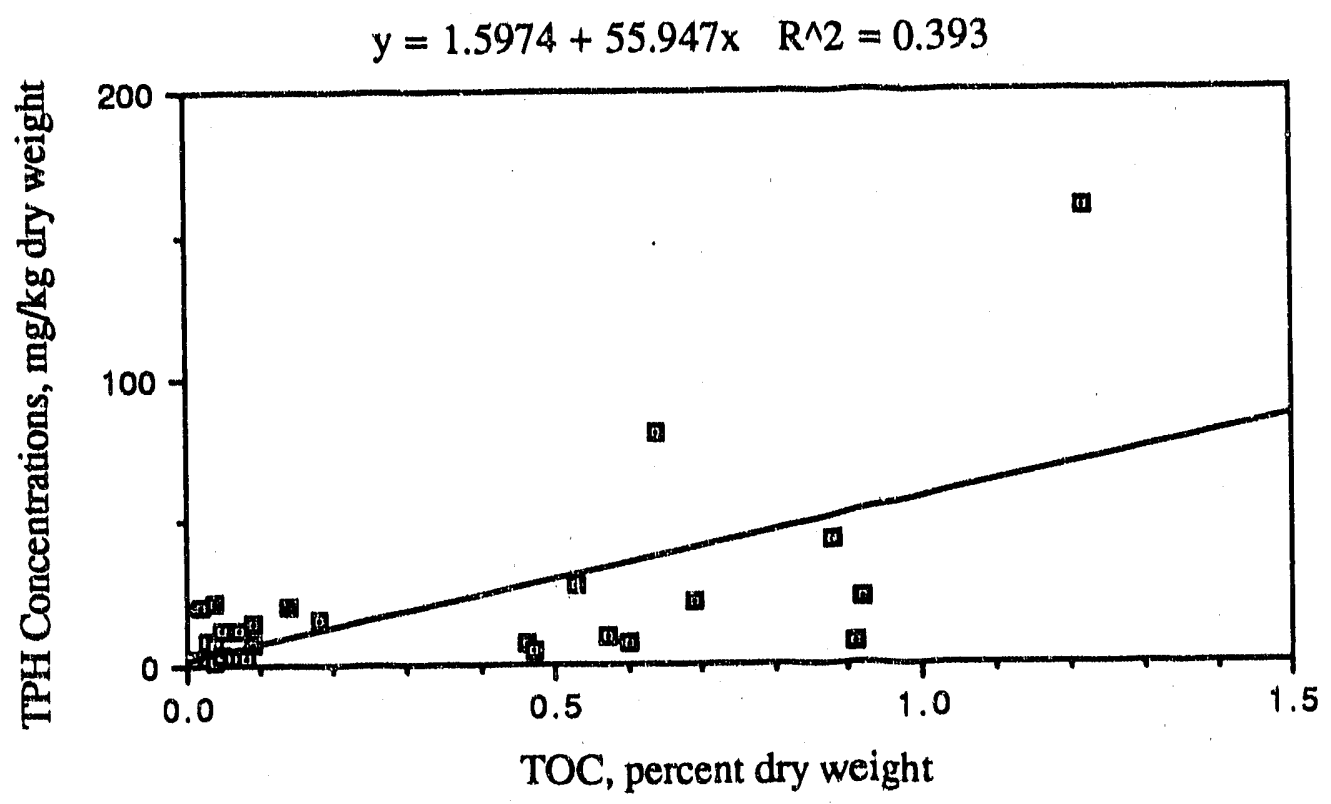

FIGURE 3.14. Linear Regression Showing the Relationship Between TPH and TOC in Oaklarid Phase III A Sediment Treatments

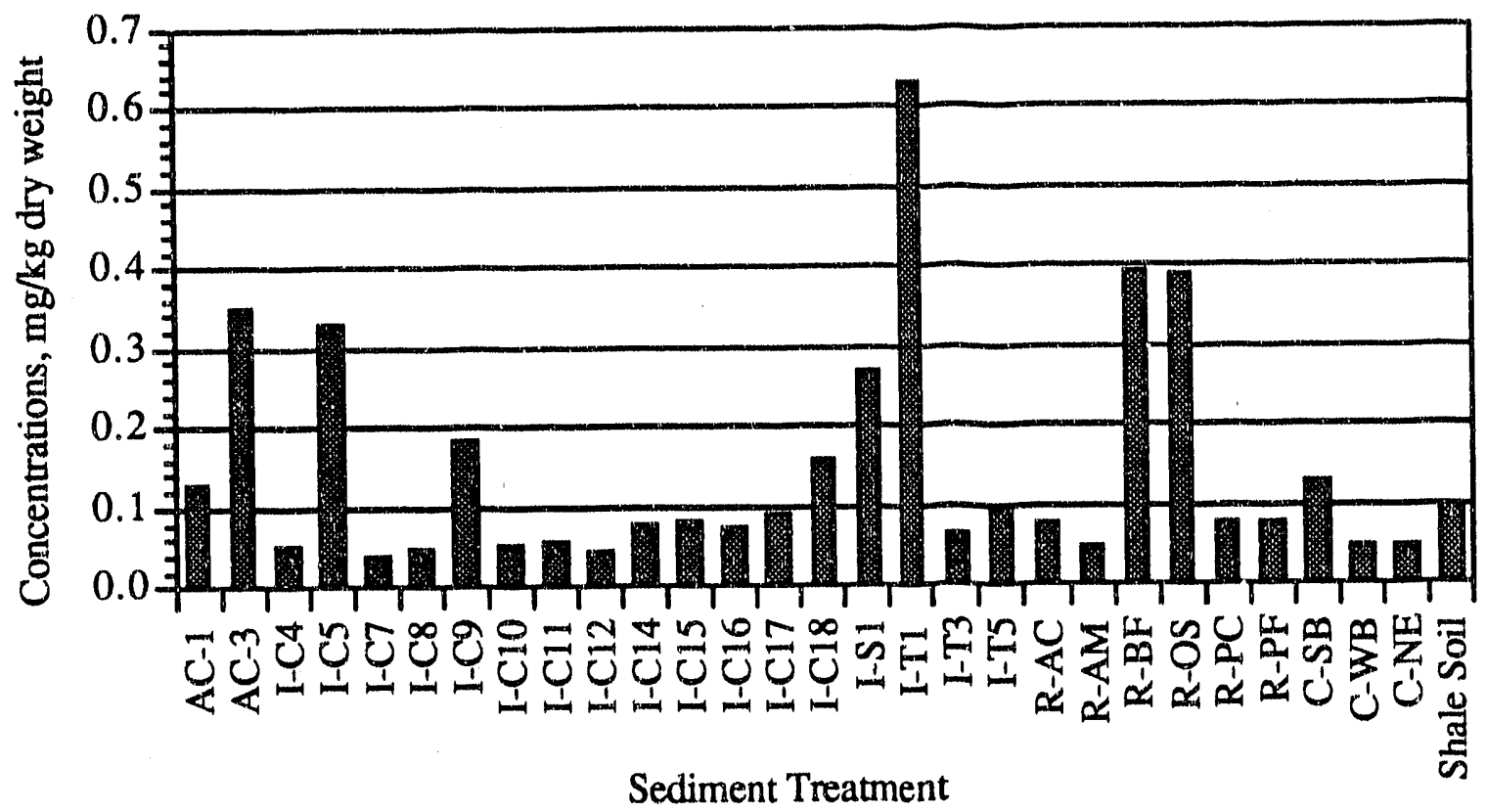

EIGURE 3.15. Concentrations of Silver Found in Oakland Phase III A Sediment Treatments 
Bay Farm (R-BF) and offshore (R-OS) reference sediments. Table 3.2 shows the sediment treatments with $\mathrm{Ag}$ concentrations greater than that of typical shale soll. Ten of the 28 sediment treatments had Ag concentrations above those found in typical shale soil; seven of those ten were from the 19 stations within Oakland Harbor (I-T1, I-S1, I-C18, I-C9, I-C5, AC-3, and AC-1).

Concentrations of arsenic (As) found in Oakland Harbor sediment treatments and in typical shale soil are presented graphically in Figure 3.16. Concentrations ranged from undetected to $12.93 \mathrm{mg} / \mathrm{kg}$ dry weight. The six reference and three control sediments had As concentrations ranging from 2.24 to $7.83 \mathrm{mg} / \mathrm{kg}$ dry weight. This range encompasses all of the Oakland Harbor sediment treatments except AC-3, I-C5, I-C7, I-C9, I-C11, I-S1, and I-T1. For comparison, the average As concentration in shale soll is $6.6 \mathrm{mg} / \mathrm{kg}$. Five of the 19 Oakland Harbor sediment treatments had As concentrations exceeding the shale soil As concentration: I-T1, I-S1, I-C9, IC5, and Oakland Outer Harbor composite sample A-C3. Two of the reference and control treatments (R-BF and C-SB) also had As concentrations greater than $6.6 \mathrm{mg} / \mathrm{kg}$.

Concentrations of cadmium (Cd) found in Oakland Harbor sediment treatments and in typical shale soil are presented graphically in Figure 3.17. Cadmium concentrations ranged from 0.046 to $0.460 \mathrm{mg} / \mathrm{kg}$ dry weight. None of the Cd concentrations found in the Oakland Harbor sediment treatments exceeded those concentrations found in the Point Reyes coarse or fine sediment (R-PC and R-PF), the offshore sediment (R-OS), or the control sediments (C-NE and CSB). Sediment treatment I-S1 had the highest Cd concentration $(0.460 \mathrm{mg} / \mathrm{kg})$, followed by I-T1 $(0.390 \mathrm{mg} / \mathrm{kg}), \mathrm{I}-\mathrm{C} 9(0.300 \mathrm{mg} / \mathrm{kg})$, and AC-3 $(0.300 \mathrm{mg} / \mathrm{kg})$. Cadmium concentrations in the reference and control treatments range from $0.046 \mathrm{mg} / \mathrm{kg}(\mathrm{R}-\mathrm{AM})$ to $2.190 \mathrm{mg} / \mathrm{kg}$ (R-PF). The typical Cd concentration in shale soil is $0.3 \mathrm{mg} / \mathrm{kg}$. Two treatments (I-SI and I-T1) and two control sediments (C-SB and C-NE) exceeded the shale soil level.

TABLE 3.2. Oakland Harbor Phase III A Sediment Treatments with Silver Concentrations Exceeding Those Found in Typical Shale Soil

\section{Treatment}

Shale soil

AC-1

AC. -3

I-C5

I-C9

I-C18

I-S1

I-T1

R-BF

R-OS

C-SB
Ag Concentration $(\mathrm{mg} / \mathrm{kg}$ )

0.100

0.128

0.350

0.327

0.185

0.159

0.271

0.629

0.391

0.390

0.130 


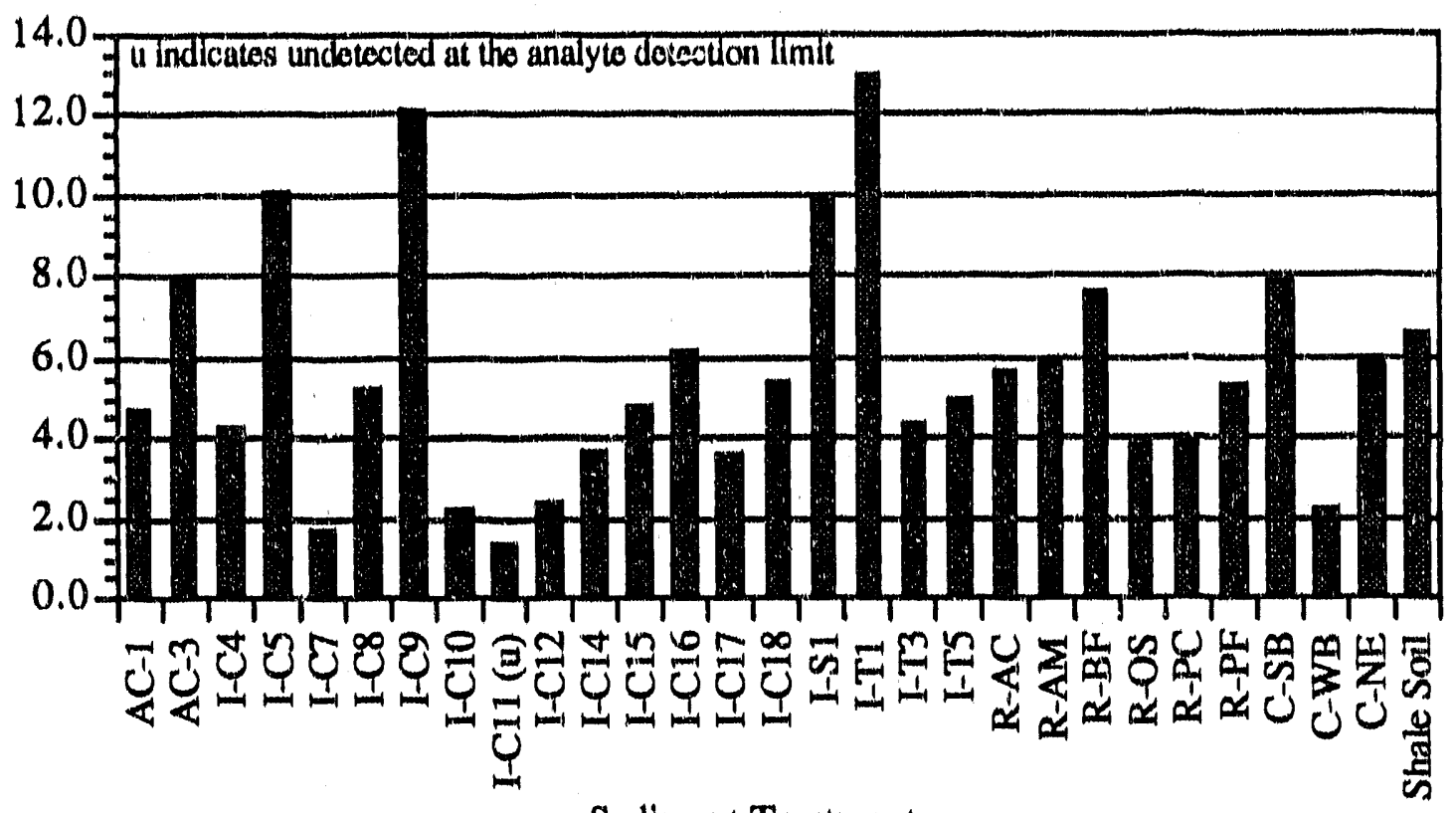

Sediment Treatment

EIGURE 3.16. Concentrations of Arsenic Found in Oakland Phase III A Sediment Treatments

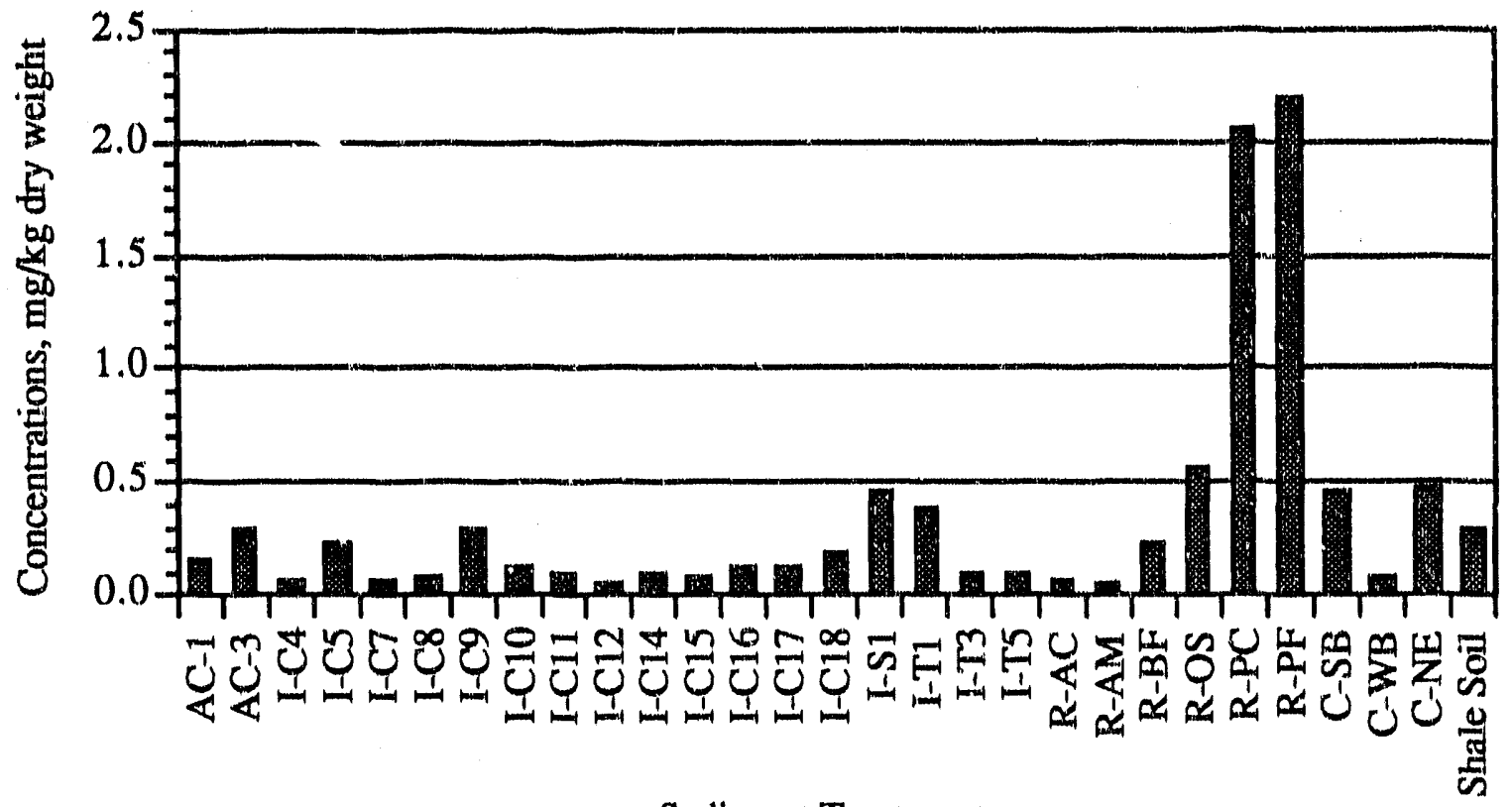

Sediment Treatment

EIGURE 3.17. Concentrations of Cadmium Found in Oakland Phase III A Sediment Treatments 
Concentrations of chromlum ( $\mathrm{Cr}$ ) found in Oakland Harbor sediment treatments and in typical shale soil are presented graphically in Figure 3.18. Chromium concentrations in the 19 Oakland Harbor sediment treatments ranged from 168 to $977 \mathrm{mg} / \mathrm{kg}$ dry weight. The six reference and three control treatments had $\mathrm{Cr}$ concentrations ranging from 113 to $364 \mathrm{mg} / \mathrm{kg}$. Chromium concentration in a typical shale soil is $1(10 \mathrm{mg} / \mathrm{kg}$ dry weight (Krauskopf 1967). All of the sediments, including references und controls, contalned $\mathrm{Cr}$ concentrations above $100 \mathrm{mg} / \mathrm{kg}$. In contrast to other metals, sediment treatment $\mathrm{I}-\mathrm{C} 10$ had tho highest concentration of $\mathrm{Cr}$, followed by I-T3 and I-C11. Sediment treatrnent I-C1O had almost ten times the Cr concentration as shale soil, and I-C11 and I-T3 had chromium levels six to seven times greater than shale soil.

Concentrations of copper $(\mathrm{Cu})$ found in Oakland Harbor sediment treatments and in typical shale soll are presented graphically in Figure 3.19. Copper concentrations in the 19 Oakland Harbor sediment treatments ranged from 9.3 to $80.7 \mathrm{mg} / \mathrm{kg}$ dry weight. The majority of $\mathrm{Cu}$ concentrations measured in the treatments were lower than those of typical shale solls, which are $57 \mathrm{mg} / \mathrm{kg}$ (Krauskopf 1967). The reference and control treatments had Cu concentrations ranging from 7.9 to $38.5 \mathrm{mg} / \mathrm{kg}$. Four sediment treatments (I-C5, I-C9, I-S1, and I-T1) had Cu concentrations exceeding those of the reference and control treatments. Two sediment treatments (I-S1 and I-T1) also had $\mathrm{Cu}$ concentrations greater than the $57 \mathrm{mg} / \mathrm{kg}$ seen in typical shale soil (Krauskopf 1.967).

Concentrations of mercury $(\mathrm{Hg})$ found in Oakland Harbor sediment treatments and in typical shale soil are presented graphically in Figure 3.20. Concentrations of $\mathrm{Hg}$ in sediment treatments ranged from 0.014 to $0.524 \mathrm{mg} / \mathrm{kg}$ dry weight. Reference and control sediments contained $\mathrm{Hg}$ concentrations that ranged from 0.02 to $0.266 \mathrm{mg} / \mathrm{kg}$; the majority of the Oakland Harbor sediment treatments fell within this range. The typical concentration of $\mathrm{Hg}$ in shale soil is $0.4 \mathrm{mg} / \mathrm{kg}$. One treatment, I-T1, had a higher value than that of shale soil (Krauskopf 1967).

Nickel (Ni) concentrations found in Oakland Harbor sediment treatments and in typical shale soil are presented graphically in Figure 3.21. Nickel concentrations in these sediment treatments ranged from 45.3 to $132.8 \mathrm{mg} / \mathrm{kg}$ dry weight. Reference and control sediments had $\mathrm{Ni}$ concentrations ranging from $33.5 \mathrm{mg} / \mathrm{kg}$ (R-AM) to $79.2 \mathrm{mg} / \mathrm{kg}$ (R-BF). Five sediment treatments (I-S1, I-T1, I-C9, I-C5, and AC-3) had Ni concentrations that exceeded the range of these reference and control sediments. Concentrations in four of those treatments (I-C5, I-C9, I-S I, and I-T1) either equaled or exceeded the typical shale soil value of $95 \mathrm{mg} / \mathrm{kg}$.

Lead $(\mathrm{Pb})$ concentrations found in Oakland Harbor sediment treatments and in typical shale soil are presented graphically in Figure 3.22. Lead concentrations in these sediment treatments 


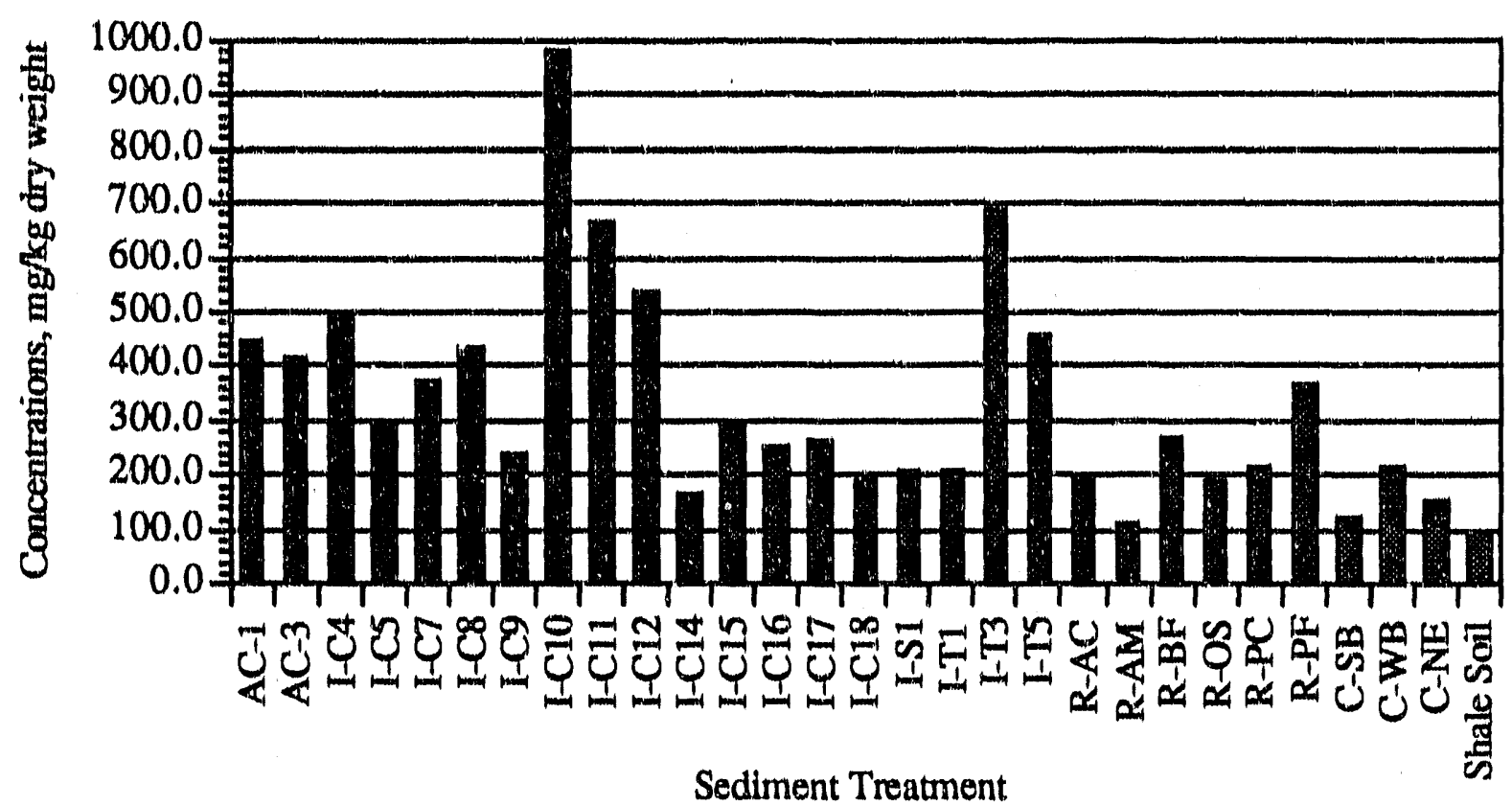

EIGURE 3.18. Concentrations of Chromium Found in Oakland Phase III A Sediment Treatments

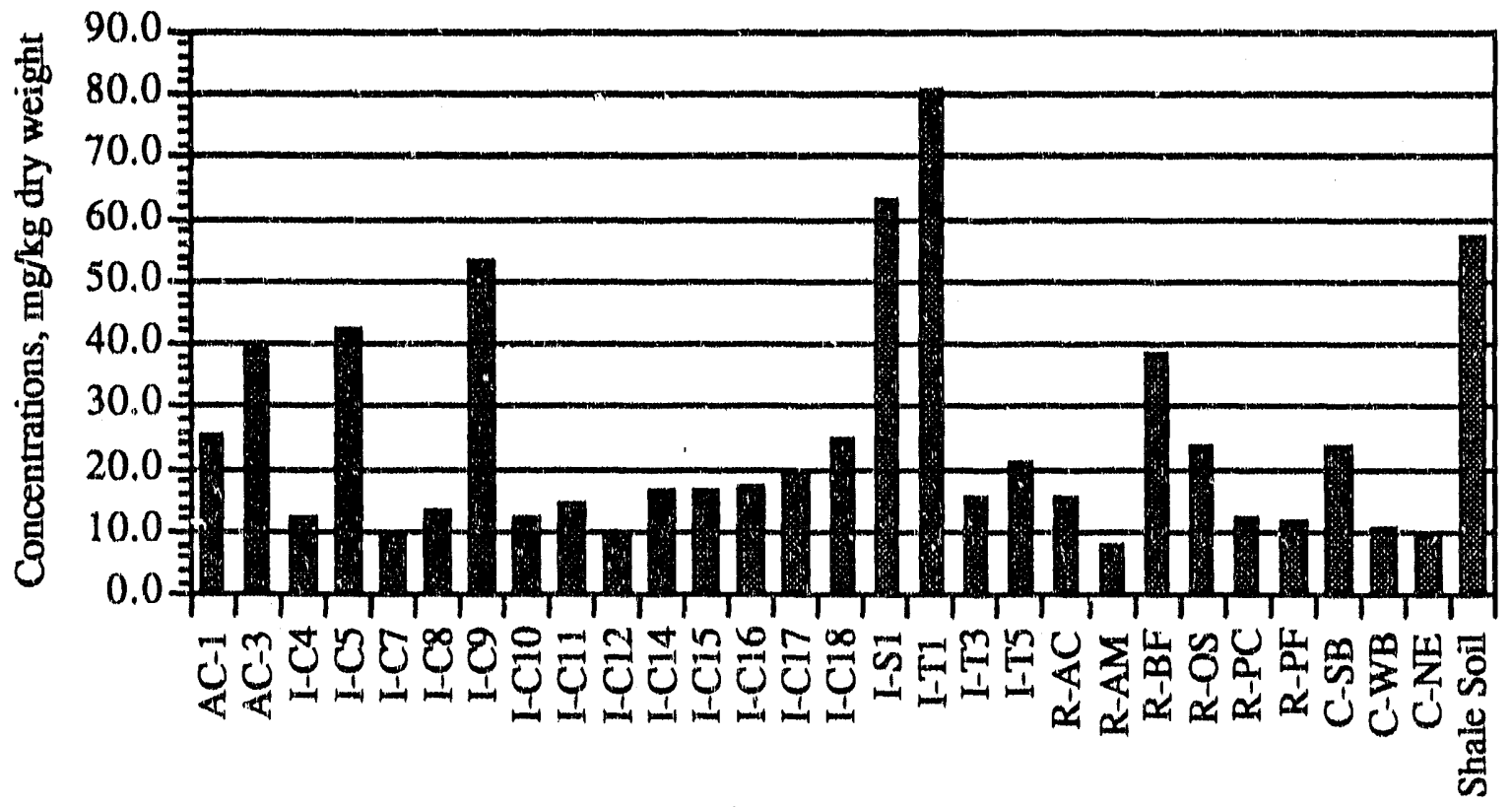

Sediment Treatmient

EIGURE 3.19. Concentrations of Copper Found in Oakland Phase III A Sediment Treatments 


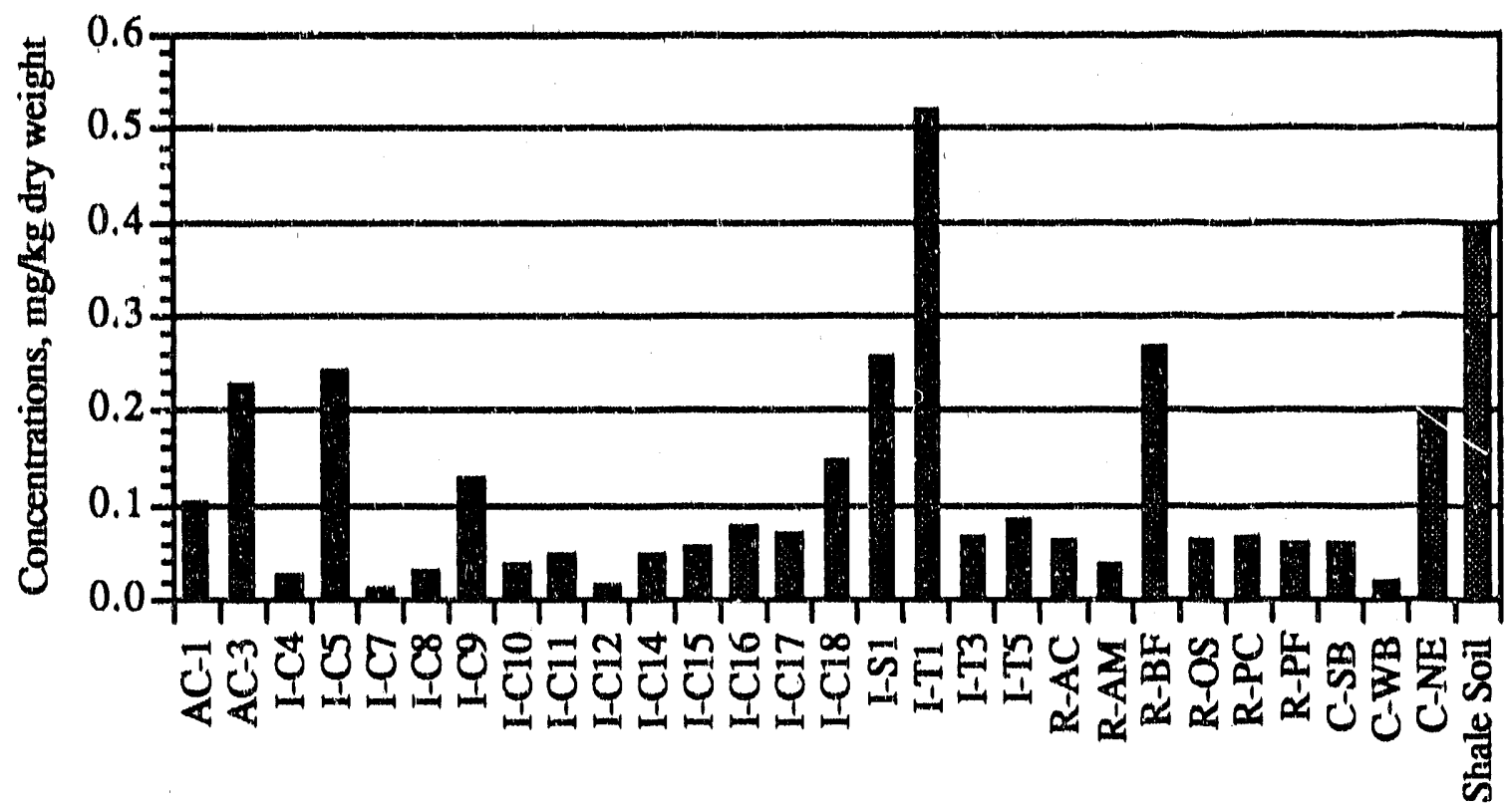

Sediment Treatment

EIGURE 3.20. Concentrations of Mercury Found in Oakland Phase III A Sediment Treatments

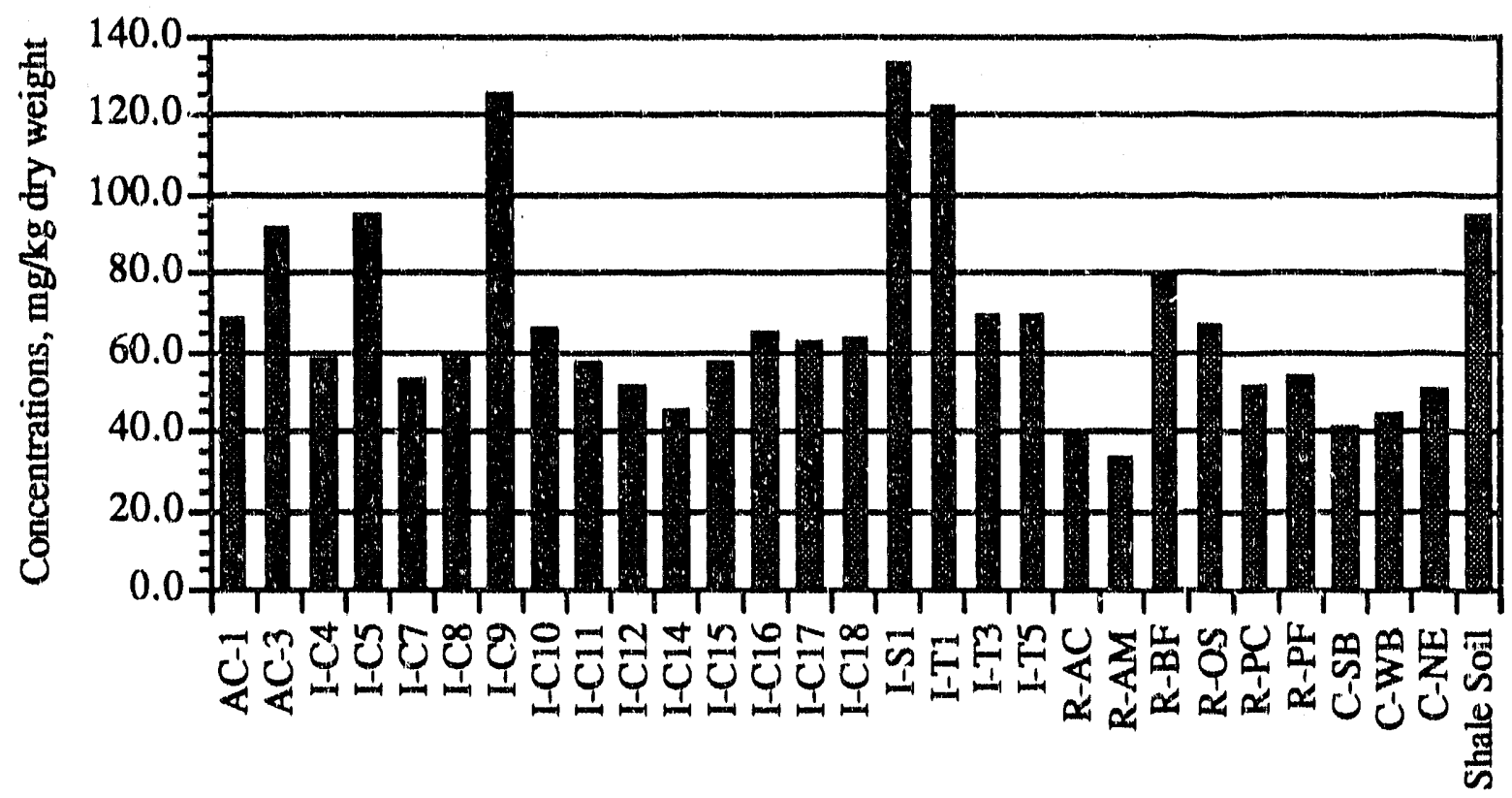

Sediment Treatment

FIGURE 3.21. Concentrations of Nickel Found in Oakland Phase III A Sediment Treatments 


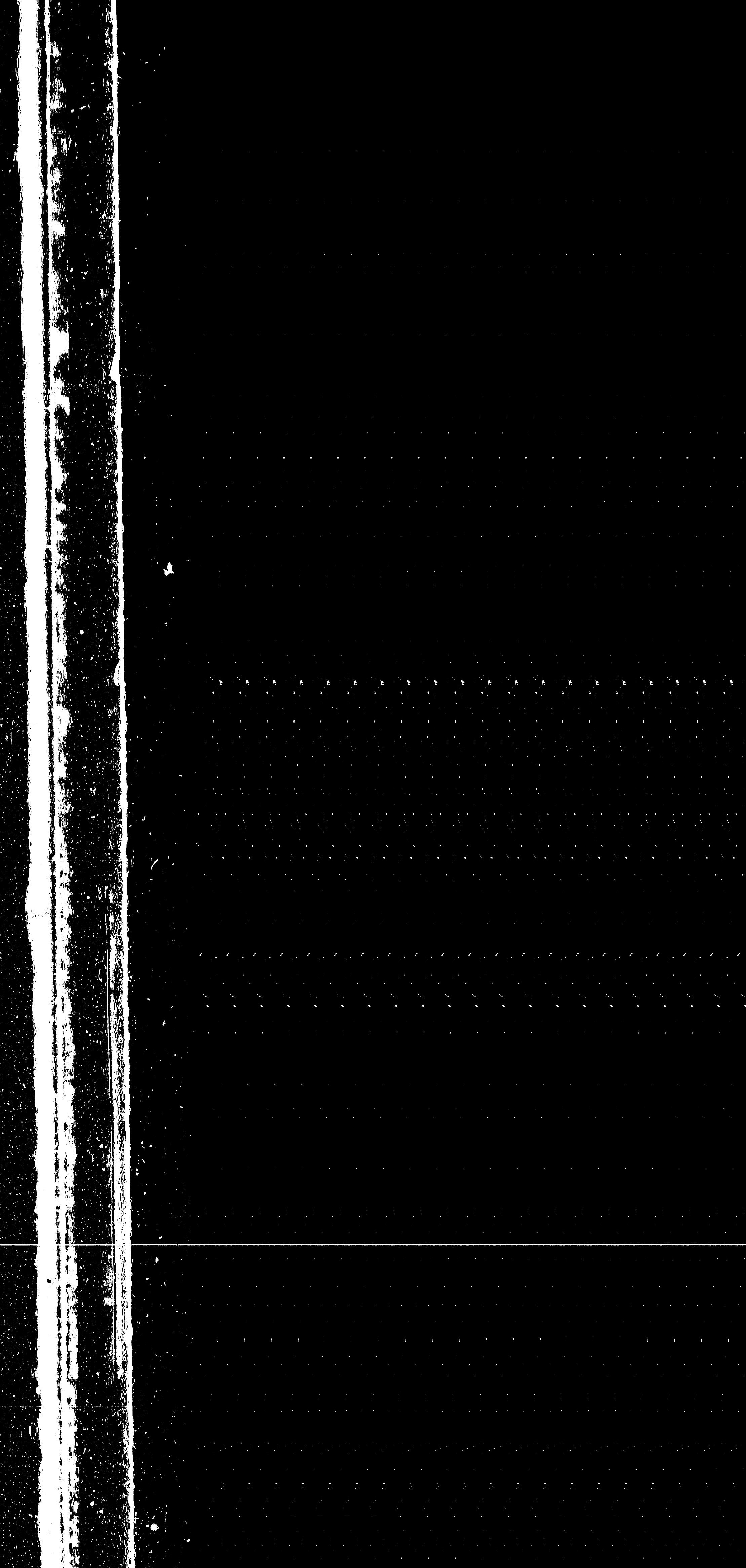




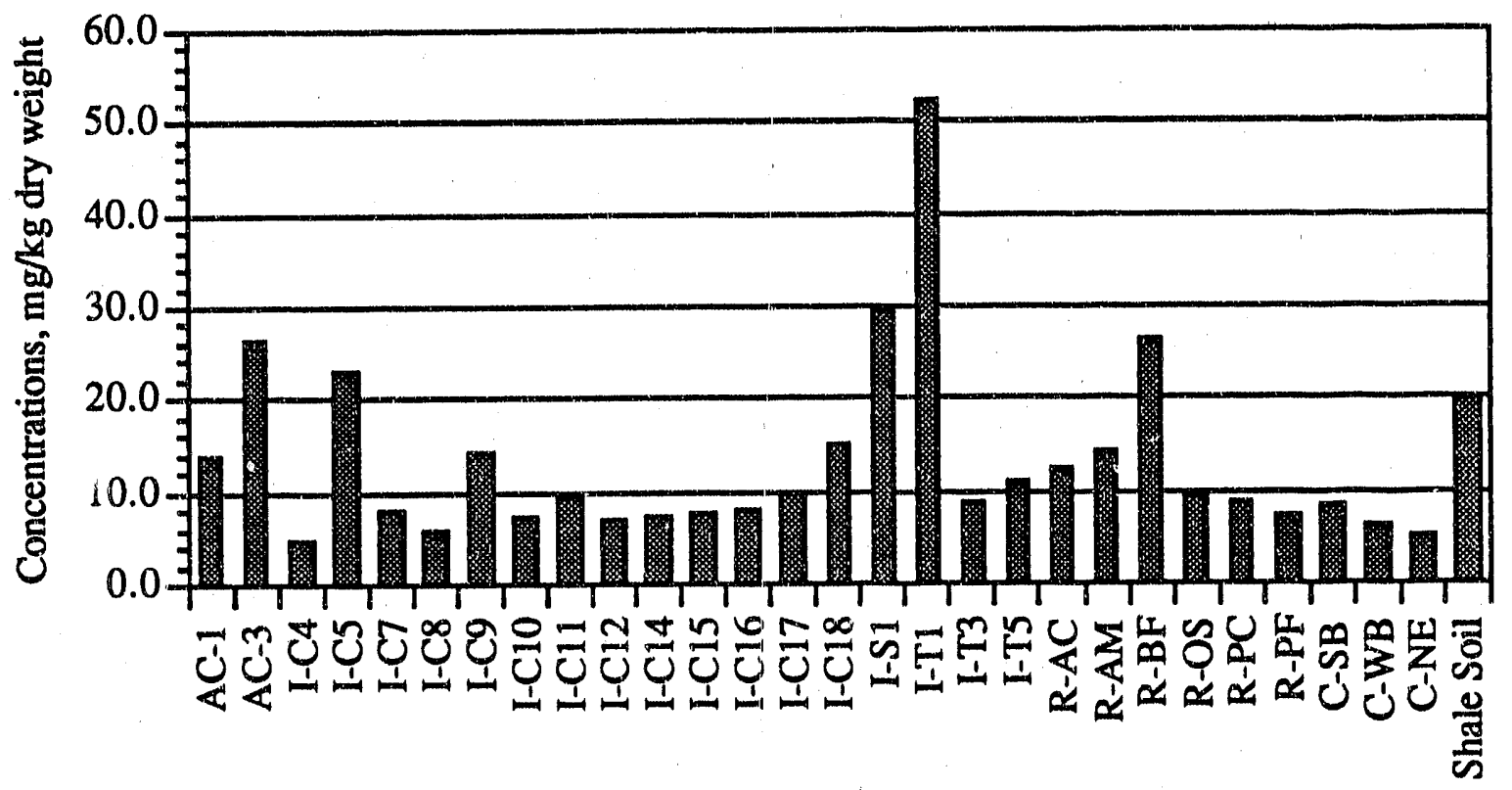

Sediment Treatment

EIGURE 3.22. Concentrations of Lead Found in Oakland Phase III A Sediment Treatments

ranged from 4.9 to $52.33 \mathrm{mg} / \mathrm{kg}$ dry weight. Lead concentrations for reference and control samples ranged from 5.33 to $26.4 \mathrm{mg} / \mathrm{kg}$. Five sediment treatments (AC-3, I-C5, I-S1, I-T1, and $\mathrm{R}-\mathrm{BF}$ ) had $\mathrm{Pb}$ concentrations exceeding the typical shale soil level of $20 \mathrm{mg} / \mathrm{kg}$. The highest $\mathrm{Pb}$ concentration was found at I-T1 $(52.33 \mathrm{mg} / \mathrm{kg})$.

Selenium (Se) was detected in only four (I-C9, I-S1, R-OS, and C-SB) of the 28 Oakland Harbor sediment treatments; Se concentrations in those samples ranged from 0.22 to $0.74 \mathrm{mg} / \mathrm{kg}$. Only one sediment treatment, R-OS, contained Se at a concentration exceeding the typical shale soil concentration of $0.60 \mathrm{mg} / \mathrm{kg}$.

Zinc $(\mathrm{Zn})$ concentrations found in Oakland Harbor sediment treatments and in typical shale soil are presented graphically in Figure 3.23. The Oakland Harbor sediment treatments had concentrations of $\mathrm{Zn}$ ranging from $35.0 \mathrm{mg} / \mathrm{kg}$ (I-C14) to $188.37 \mathrm{mg} / \mathrm{kg}$ (I-T1). Reference treatment R-AM had the lowe ${ }^{*} \cdot \mathrm{Zn}$ concentration $(32.0 \mathrm{mg} / \mathrm{kg})$ and reference treatment $\mathrm{R}-\mathrm{BF}$ had the highest concentration $(106.80 \mathrm{mg} / \mathrm{kg})$. Seven sediment treatments had $\mathrm{Zn}$ oncentrations that exceeded the average shale soil concentration of $80 \mathrm{mg} / \mathrm{kg}$ (Krauskopf 1967). Concentrations of $\mathrm{Zn}$ in four of the Oakland Harbor sediment treatments exceeded $\mathrm{Zn}$ concentrations at the Bay Farm and offshore reference sites (R-BF and R-OS). 


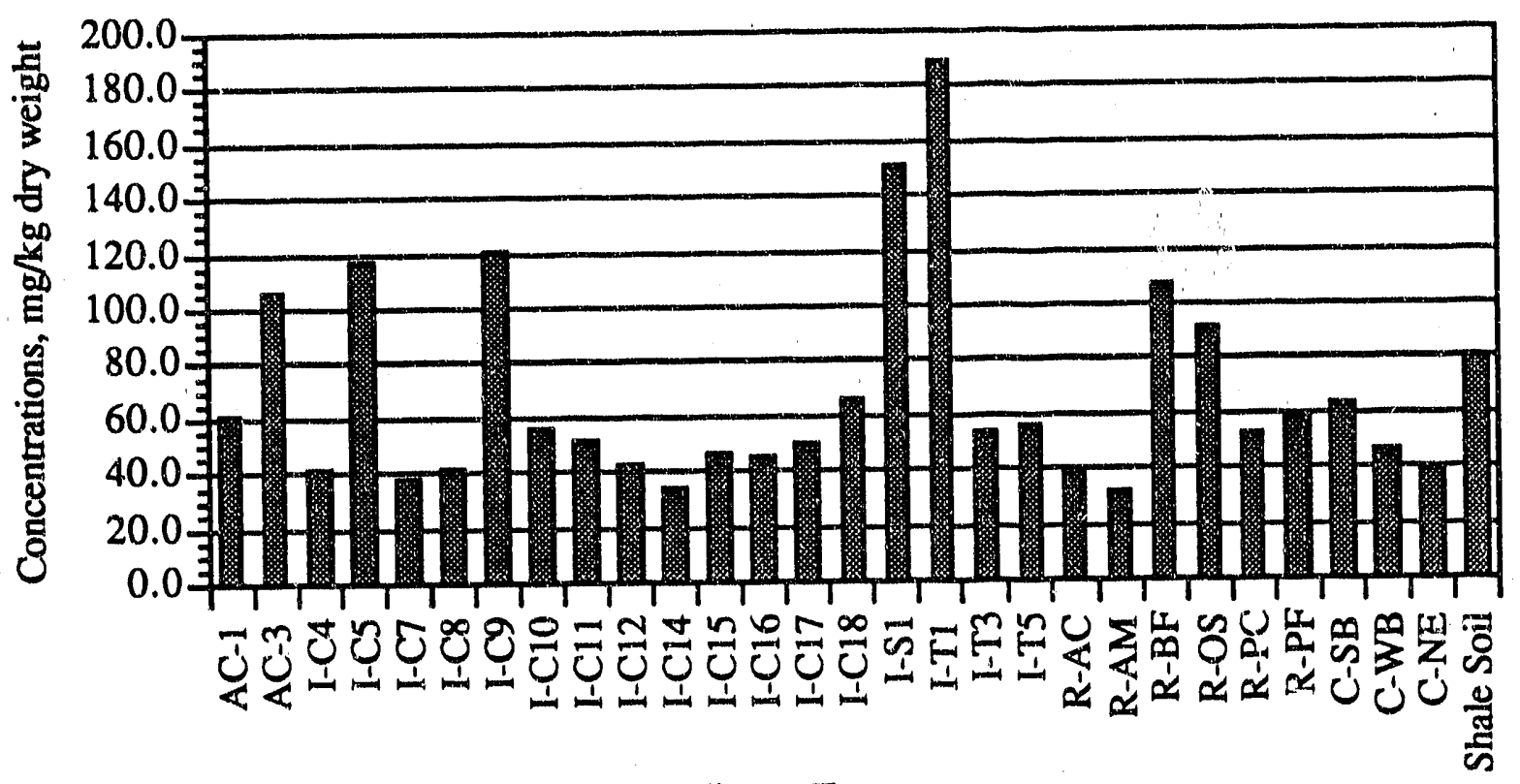

Sediment Treatment

EIGURE 3.23. Concentrations of Zinc Found in Oakland Phase III A Sediment Treatments

\subsubsection{Chlorinated Pesticides and PCBs}

Results of analysis of the Oakland Harbor sediment treatments for chlorinated pesticides are presented in Volume 2, Appendix C, Table C.9. Pesticide and PCB data are presented in $\mu \mathrm{g} / \mathrm{kg}$ dry weight. No pesticides were detected in any of the sediment treatments above the achieved detection limits. Analysts noted PCB peaks for Aroclor 1254 and 1260 that were below target detection limits in some sediment treatments. These results are shown in Table 3.4. The PCB concentrations found in Oakland Harbor sediment treatments are provided in Volume 2, Appendix C, Table C.7.

\subsubsection{Polynuclear Aromatic Hydrocarbons}

The PAH concentrations found in Oakland Harbor sediment treatments are provided in Appendix C, Tables C.2 and C.3. Results of LPAH analyses are summarized and presented grophically in Figure 3.24. Concentrations of total LPAH ranged from 1 to $288 \mu \mathrm{g} / \mathrm{kg}$ dry weight. Sediment treatments from Stations I-C5, I-S1 and I-T1 had the highest LPAH concentrations at $115 \mu \mathrm{g} / \mathrm{kg}, 288 \mu \mathrm{g} / \mathrm{kg}$, and $194 \mu \mathrm{g} / \mathrm{kg}$, respectively. Results of HPAH analyses are summarized and presented graphically in Figure 3.25. Total HPAH concentrations ranged from undetected to $2421 \mu \mathrm{g} / \mathrm{kg}$ dry weight. Concentrations of HPAH were also highest in sediment treatments from 
TABLE 3.4. PCB Concentrations Found in Oakland Phase III A Sediment Treatments

\section{Sediment \\ Treatment}

AC-1

AC-3

I-C5

I-S1

I-T1

I-T3

R-AC.

$\frac{\text { Concentration }(\mathrm{mg} / \mathrm{kg})}{\text { Aroclor } 1254}$

$16 \mathrm{~J}(\mathrm{a})$

26.

$19 \mathrm{~J}$

$28 \mathrm{~J}$

66

$26 \mathrm{~J}$

$17 \mathrm{~J}$
$\mathrm{ND}$ (b)

44

ND

ND

ND

ND

$21 \mathrm{~J}$

(a) Analyte detected below method detection limit, but above instrument detection limit.

(b) Not detected.

three stations: I-T1 $(2421 \mu \mathrm{g} / \mathrm{kg}), \mathrm{I}-\mathrm{S} 1(1032 \mu \mathrm{g} / \mathrm{kg})$, and I-C5 $(856 \mu \mathrm{g} / \mathrm{kg})$. All of the remaining treatments had total HPAH concentrations at or below $528 \mu \mathrm{g} / \mathrm{kg}$.

Figure 3.26 graphically compares the total LPAH load to the total HFAH load in the Oakland Harbor sediment treatments. The greatest contributor of total PAHs is represented by HPAHs with 24 of the 28 sediment treatments containing HPAHs in the highest percentages $(>50 \%$ of the total).

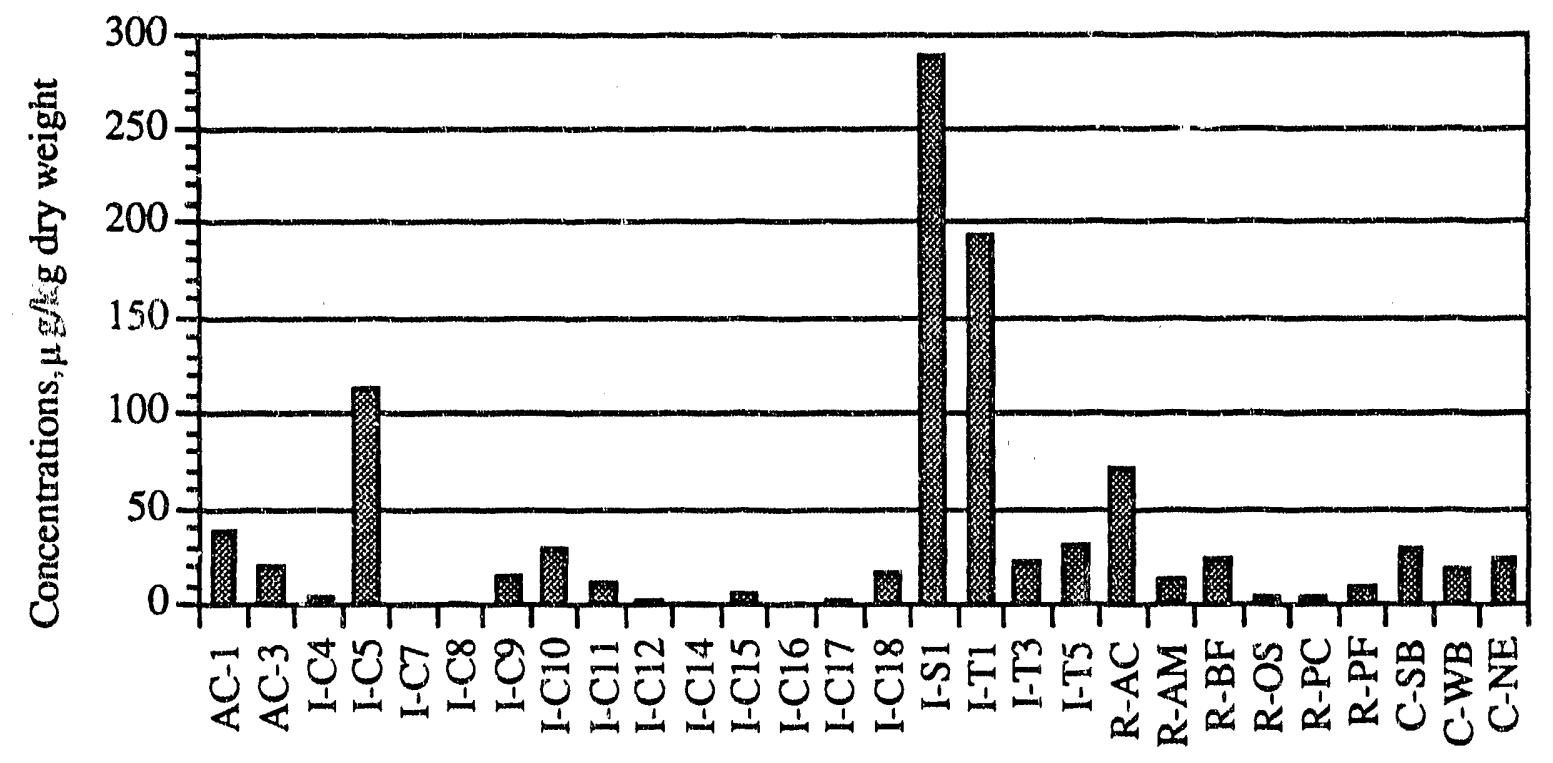

Sediment Treatment

EIGURE 3.24. Concentrations of LPAH Found in Oakland Phase III A Sediment Treatments 


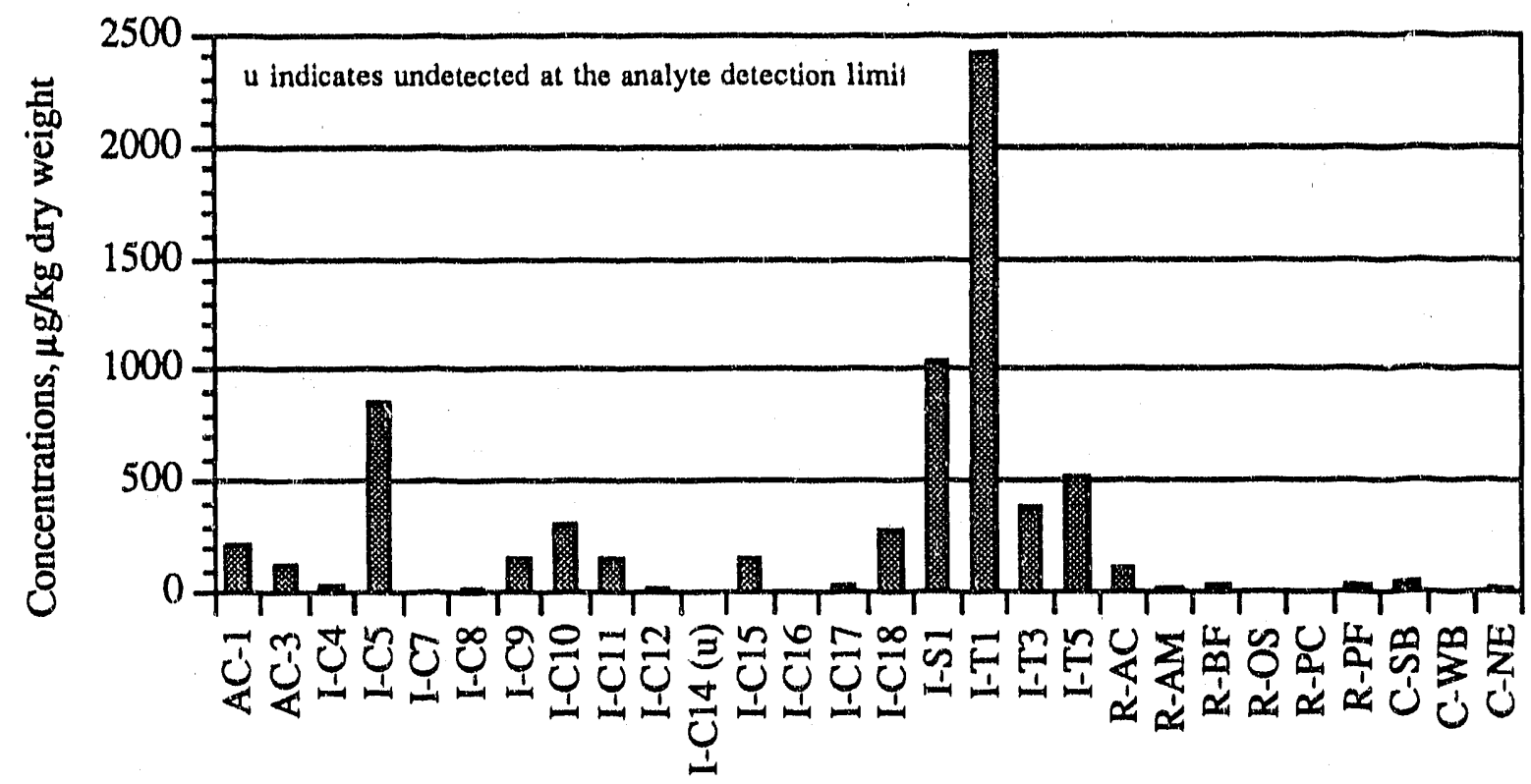

Sediment Treatment

FIGURE 3.25. Concentrations of HPAH Found in Oakland Phase III A Sediment Treatments

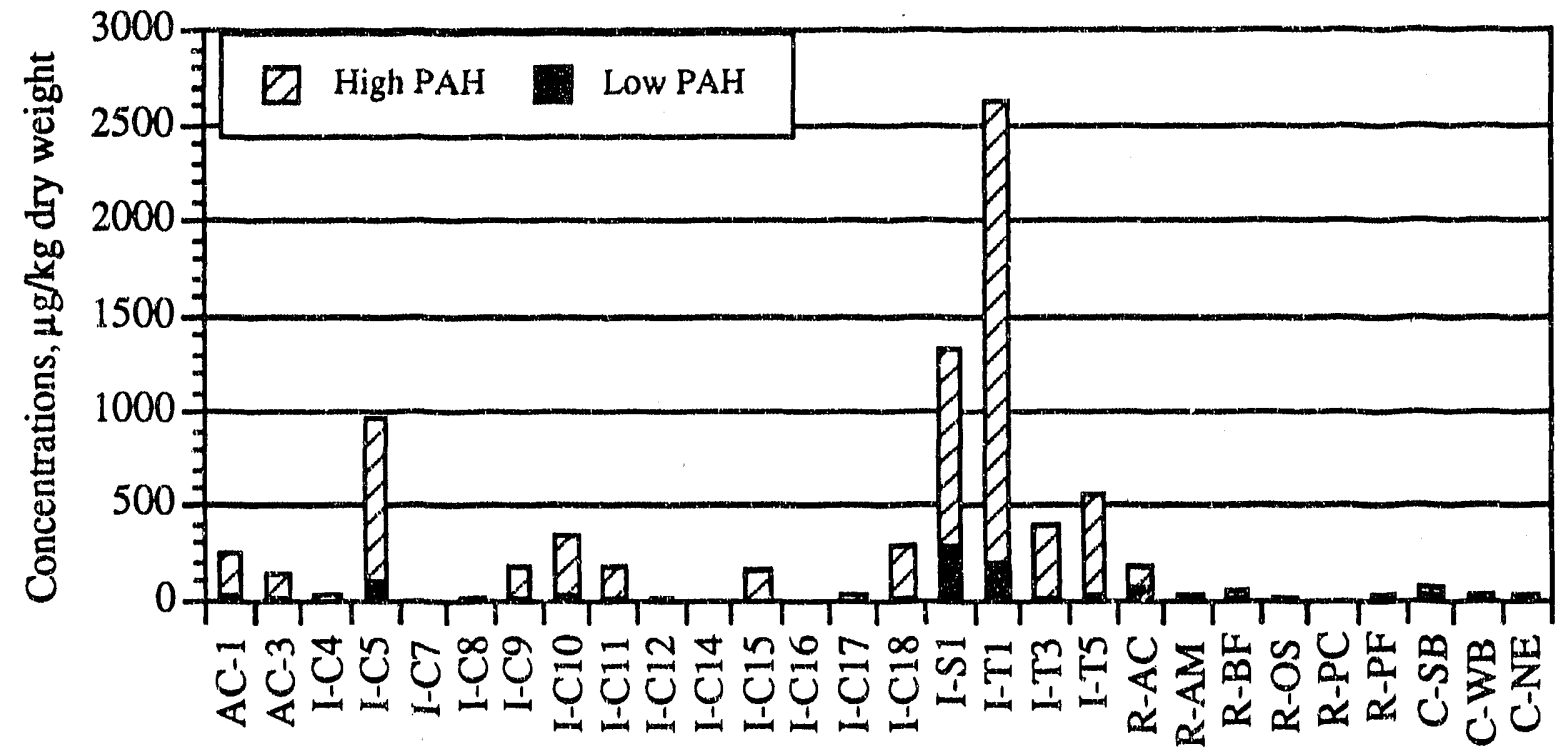

Sediment Treatments

EIGURE 3.26. Concentrations of LPAH and HPAH Found in Oakland Phase III A Sediment Treatments 


\subsubsection{Butlutin Compounds}

Results of analysis of Oakland Harbor sediment treatments for butyltins are presented in Appendix C, Table C.16. Concentrations of monobutyltin ranged from undetected to $5.80 \mu \mathrm{g} / \mathrm{kg}$. Dibutyltin concentrations ranged from undetected to $30.0 \mu \mathrm{g} / \mathrm{kg}$, and tributlytin concentrations ranged from undetected to $48.00 \mu \mathrm{g} / \mathrm{kg}$. Figures $3.27,3.28$, and 3.29 graphically present concentrations of mono-, di-, and tributyltins in each sediment treatment, respectively. Sediment from stations I-T1 and I-T5 had the highest concentrations of each of these butyltins.

\subsection{RETEST RESULTS OE PHYSICALAND CHEMICAL ANALYSES ON SEDIMENTS}

This section describes the chemical analyses performed on 16 additional sediment treatments from Oakland Harbor, six reference sites (R-AC, R-AM, R-BF, R-OS, R-PC, and R-PF) and three control sites (C-SB, C-NE, and C-WB). These sediments were resampled and retested because of the high mortality of $N$. caecoides in the control sediment (C-NE) during the initial Oakland Harbor Phase III A testing.

\subsubsection{Conventional Measurements for Sediment Analysis (Retest)}

Results of sediment grain size analysis are listed in Table 3.5, and presented graphically in Figure 3.30. Complete results of grain size analysis are provided in Volume 2, Appendix D, Table D.23. Results are reported as percentages of gravel, sand, silt, and clay in each sediment treatment. Grain size fractions in 15 of the 16 test sediment treatments were sand sized or smaller. Four sediment treatments (I-C5, I-C9, I-S1, and I-T1) were predominantly clay ( 243$)$. For the Phase III A retest bioassay, six reference sediments were used as a comparison to the test sediments. Two of these, R-AM and R-PC, are characteristic of sand sized or larger sediments. The remaining four references, $\mathrm{R}-\mathrm{AC}, \mathrm{R}-\mathrm{BF}, \mathrm{R}-\mathrm{OS}$, and R-PF, are representative of clay- and finer-sized sediments. Of the three control sediments, C-SB is predominantly silt while C-WB and C-NE are sand sized or larger.

Figure 3.31 illustrates TOC concentrations found in the 16 Oakland Harbor Phase III A retest sediment treatments. Concentrations of TOC in the 16 sediment treatments ranged from $0.03 \%$ to $1.33 \%$ dry weight. Complete data for TOC are presented in Appendix D, Table D.18. In general, the relationship between TOC and coarse-grained sediment is inverse, as demonstrated by the linear regression in Figure 3.32. Stations C-SB, R-AC, I-C.5, I-C9, I-S1, and I-T1 had the highest TOC levels and are predominantly clay or finer in grain size. 


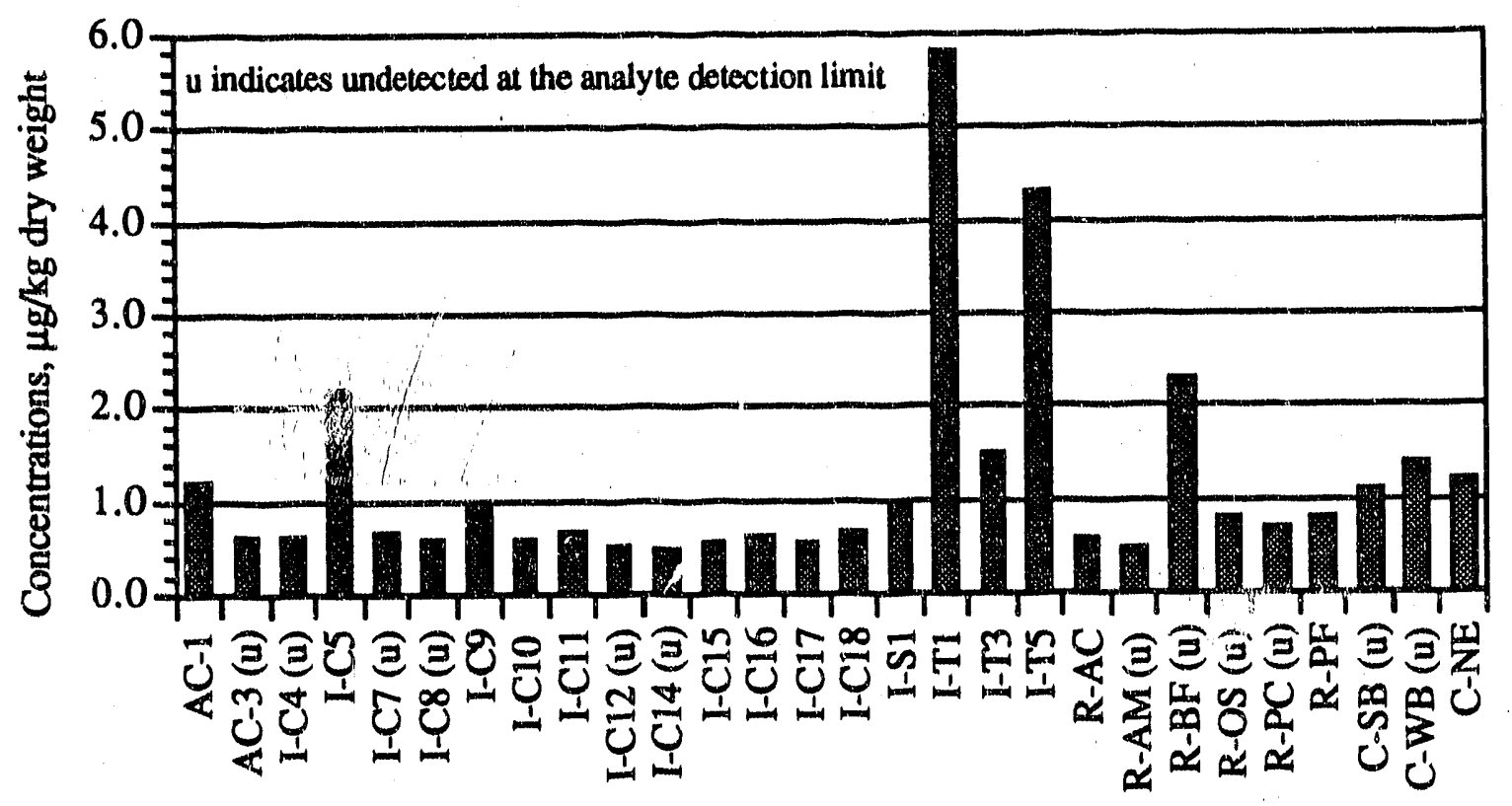

Sediment Treatment

EIGURE 3.27. Concentrations of Monobutyltin Found in Oakland Phase III A Sediment Treatments

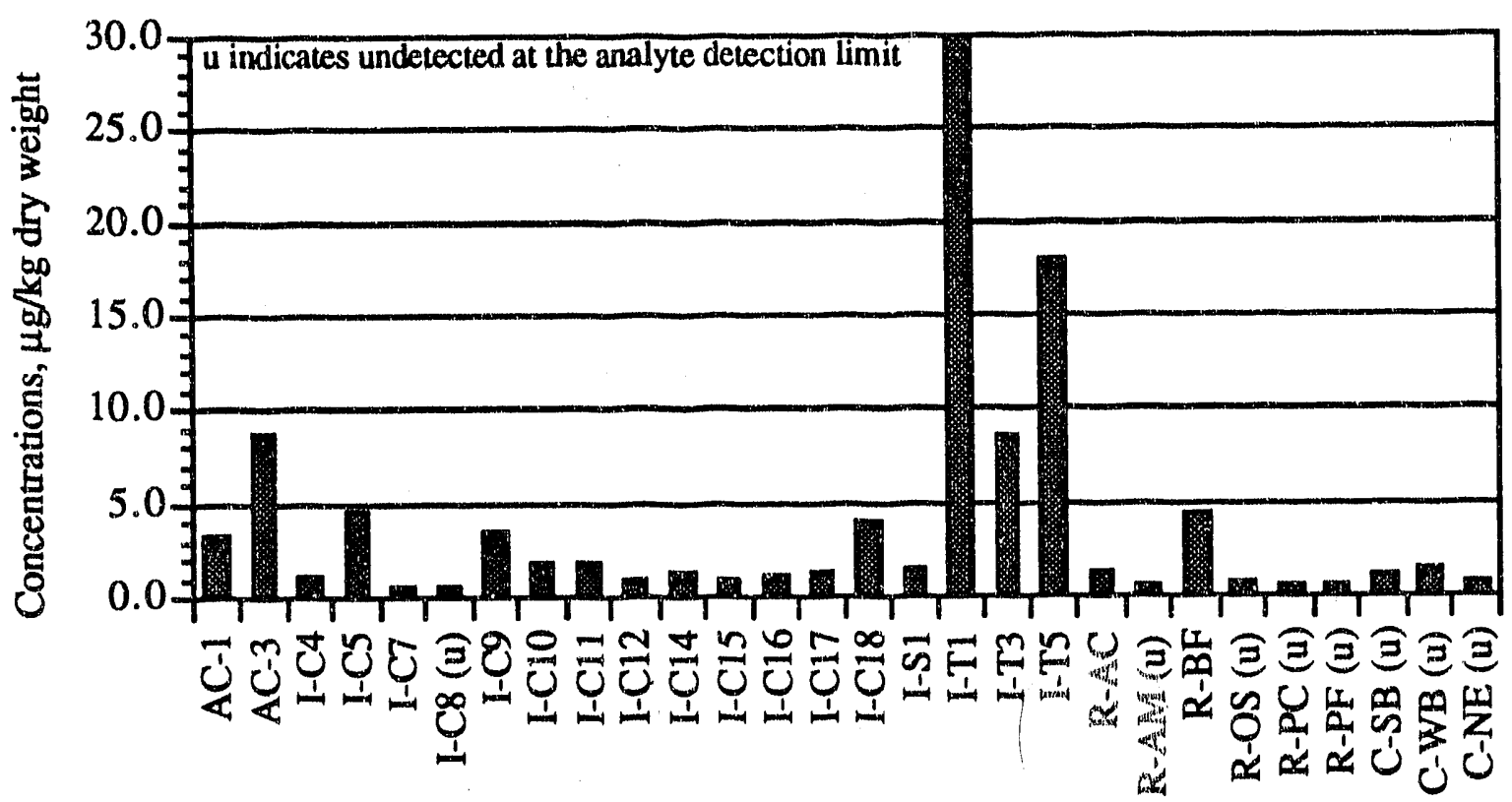

Sediment Treatment

FIGURE 3.28. Concentrations of Dibutyltin Found in Oakland Phase III A Sediment Treatments 


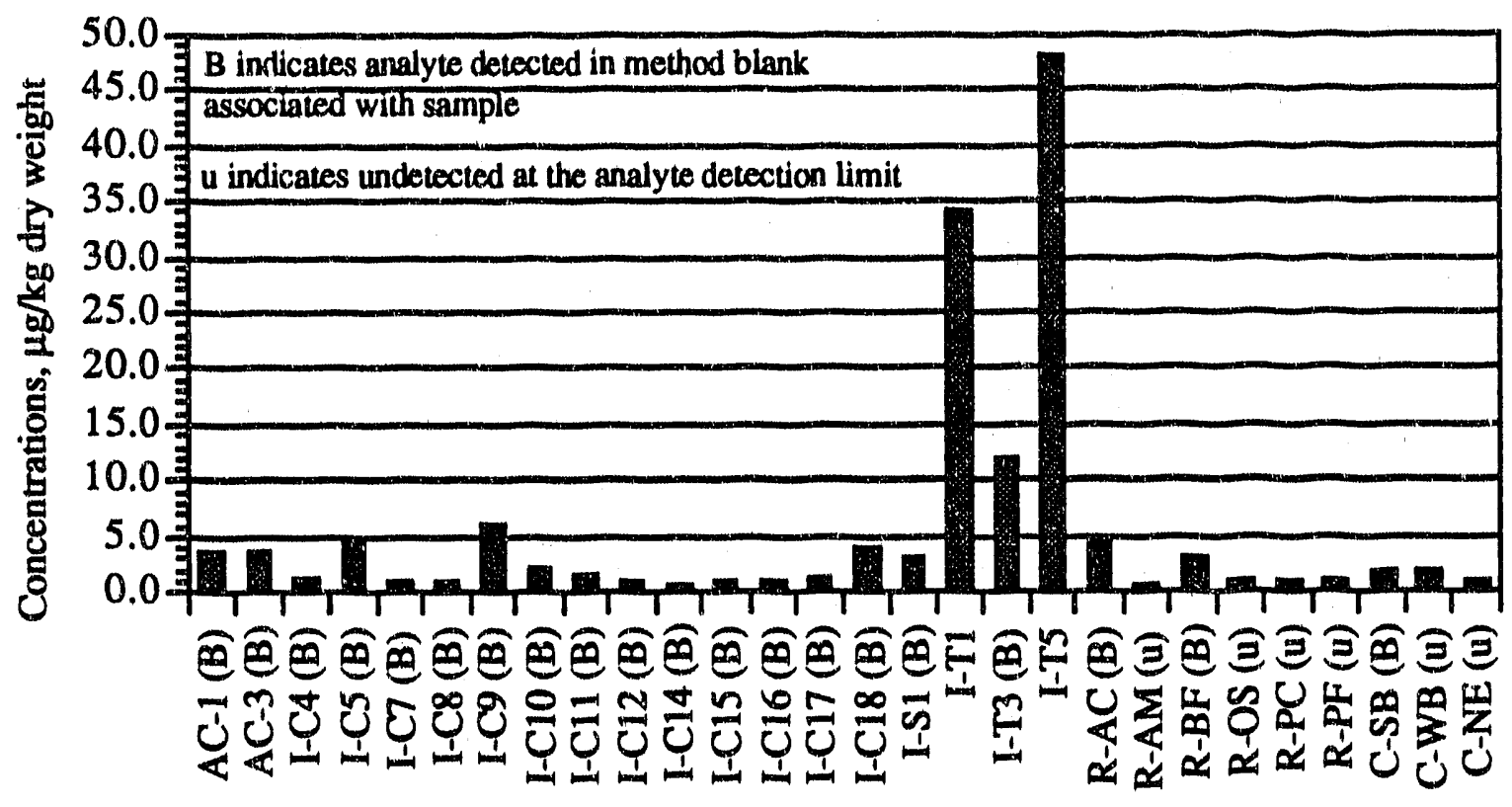

Sediment Treatment

EIGURE 3.29. Concentrations of Tributyltin Found in Oakland Phase III A Sediment Treatments

Results of TVS analysis for Oakland Harbor Phase III A retest samples are presented graphically in Figure 3.33. Data for TVS are reported in Volume 2, Appendix D, Table D.20. The TVS concentrations in the reference and control samples ranged from $1.19 \%$ to $10.71 \%$. The TVS content in sediment test (reatments was similar, ranging from $1.19 \%$ (I-C3) to $9.4 \%$ (I-T1).

Figure 3.34 shows a linear regression representing the relationship between TVS and TOC. This is a positive correlation, as indicated by the coefficient of determination of 0.897 . Sediment from stations I-S1, I-T1, and I. C5 had both the highest TVS and the highest TOC concentrations.

Results of oil and grease and TPH in Oakland Harbor Phase III A retest samples are presented graphically in ligures 3.35 and 3.36. Data for oil and grease and TPH are reported in Volume 2, Appendix D, Table D.16. Sediment treatment I-C17 had the lowest oil and grease concentration $(6 \mathrm{mg} / \mathrm{kg}$ ) and I-S1 had the highest concentration $(344 \mathrm{mg} / \mathrm{kg})$. Oil and grease concentrations at three sediment treatments, I-S1, I-T1, and I-C5, were higher than the range of concentrations found at the reference and control stations (13 to $92 \mathrm{mg} / \mathrm{kg}$ ). Total petroleum hydrocarbons ranged from undetected to $267 \mathrm{mg} / \mathrm{kg}$. Again, sediment treatments I-C5, I-S1, and I-T1 were at or above the reference and control range of undetected to $78 \mathrm{mg} / \mathrm{kg}$. Figure 3.37 shows a linear regression representing the relationship between oil and grease and TPH. These compounds are highly related, as indicated by the coefficient of determination of 0.955 . Those 
TABLE 3.5. Summary of Results of Grain Size Analysis of Oakland Harbor Phase III A Retest Sediment Samples

\begin{tabular}{lccrr} 
Sediment & & & & \\
Treatment & \% Gravel & \% Sand & Silt & Clay \\
\cline { 2 - 5 } I-C3 & 0 & 94 & 2 & 4 \\
I-C5 & 0 & 9 & 40 & 51 \\
I-C7 & 0 & 96 & 2 & 3 \\
I-C8 & 0 & 83 & 9 & 8 \\
I-C9 & 0 & 20 & 37 & 43 \\
I-C10 & 0 & 89 & 4 & 7 \\
I-C11 & 0 & 53 & 28 & 19 \\
I-C12 & 0 & 82 & 6 & 12 \\
I-C14 & 5 & 64 & 18 & 23 \\
I-C15 & 0 & 38 & 39 & 26 \\
I-C16 & 0 & 25 & 49 & 26 \\
I-C17 & 0 & 39 & 35 & 24 \\
I-C18 & 0 & 38 & 38 & 66 \\
I-S1 & 0 & 4 & 30 & 9 \\
I-T1 & 0 & 3 & 34 & 45 \\
I-T3 & 0 & 86 & 5 & 1 \\
R-AC & 0 & 15 & 40 & 25 \\
R-AM & 0 & 94 & 1 & 22 \\
R-BF & 4 & 51 & 44 & 5 \\
R-OS & 0 & 32 & 13 & 11 \\
R-PC & 0 & 82 & 28 & 30 \\
R-PF & 0 & 61 & 50 & 1 \\
C-SB & 0 & 20 & 1 & 4 \\
C-WB & 0 & 98 & 1 &
\end{tabular}

stations with high oil and grease levels also have a similiar pattern for TPH. Stations I-S1 and I-T1 had the highest concentrations of both oil and grease and TPH.

Figure 3.38 shows a linear regression representing the relationship between TPH and TOC. The relationship between TPH and TOC for these retest analyses is not as consistent as it was for the initial Oakland Harbor Phase III A analyses. This inconsistency is particularly noticeable at Station I-S1. Between the two analyses, results at this station went from very low TPH and PAH concentrations to high TPH and PAH concentrations.

\subsubsection{Metals (Retest)}

This section presents results of analyses of the Oakland Harbor Phase III A retest sediments for metals. Data for metals analyses are found in Volume 2, Appendix D, Table D.12. Metals concentrations found in test sediments will be compared to those found in reference and control sediments, and metals concentrations in all test treatments will be compared to typical metals concentrations found in shale soil. 


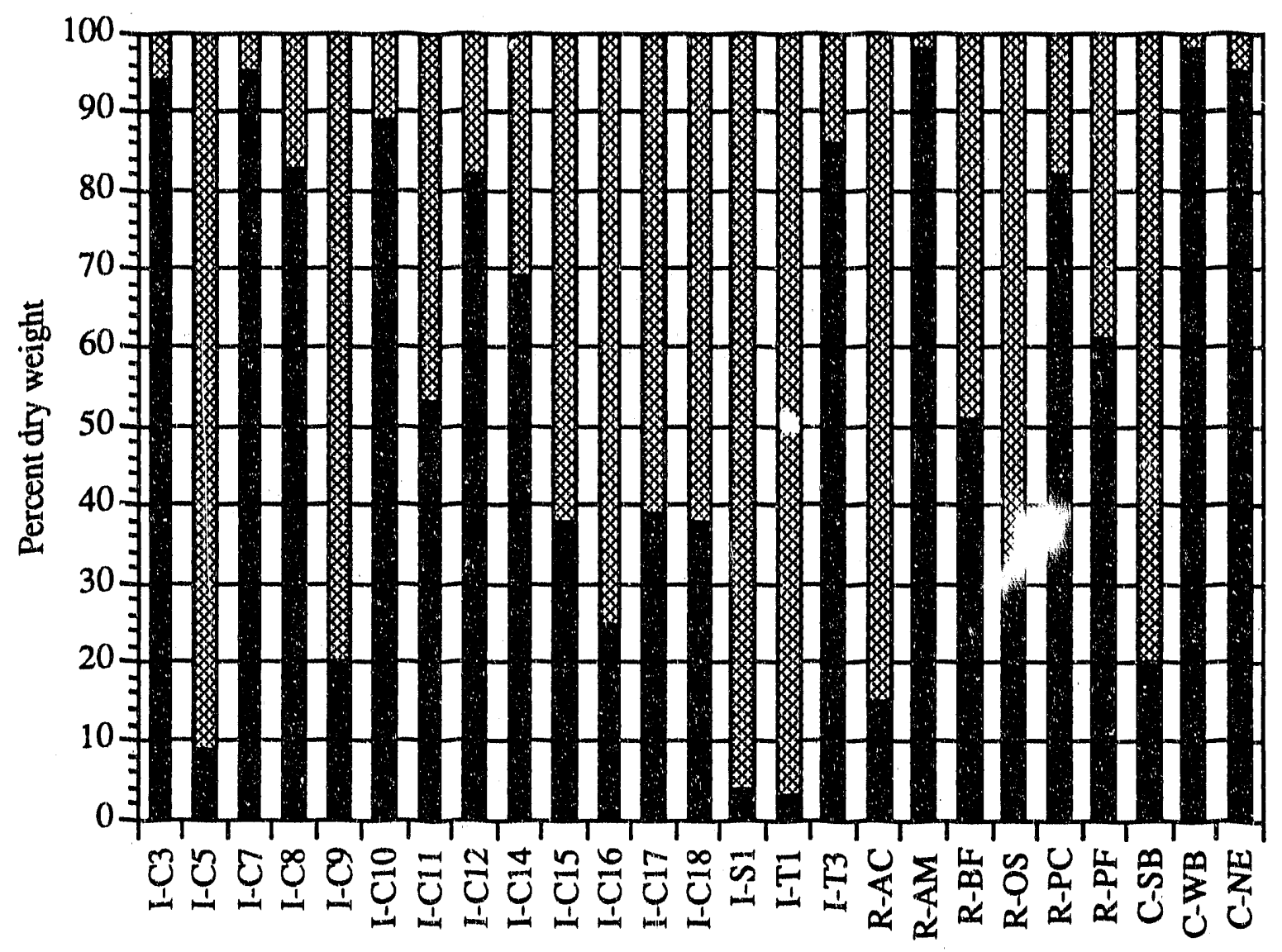

Sediment Treatments

Fine Sed. Coarse Sed.

EIGURE 3.30. Results of Sediment Grain Size Analysis of Oakland Harbor Phase III A Retest Sediment Treatments (Coarse Sediments are Composed of Sand and Gravel; Fine Sediments are Composed of Silts and Clays.)

Oakland Harbor sediment samples were analyzed for ten metals: $\mathrm{Ag}, \mathrm{As}, \mathrm{Cd}, \mathrm{Cr}, \mathrm{Cu}, \mathrm{Hg}$, $\mathrm{Ni}, \mathrm{Pb}, \mathrm{Se}$, and $\mathrm{Zn}$. Silver concentrations found in each sediment treatment and in typical shale soil are presented graphically in Figure 3.39. Silver concentrations in the 16 Oakland Harbor Phase III A retest sediment treatments ranged from 0.05 at Station I-C15 to $0.59 \mathrm{mg} / \mathrm{kg}$ at Station I-S1. In four sediment treatments, I-C5, I-C9, I-S1, and I-T1, Ag concentrations exceeded the reference and control range of 002 to $0.32 \mathrm{mg} / \mathrm{kg}$. Table 3.6 shows the sediment treatments with Ag concentrations that exceeded the typical shale soil value of $0.10 \mathrm{mg} / \mathrm{kg}$ (Krauskopf 1967). 


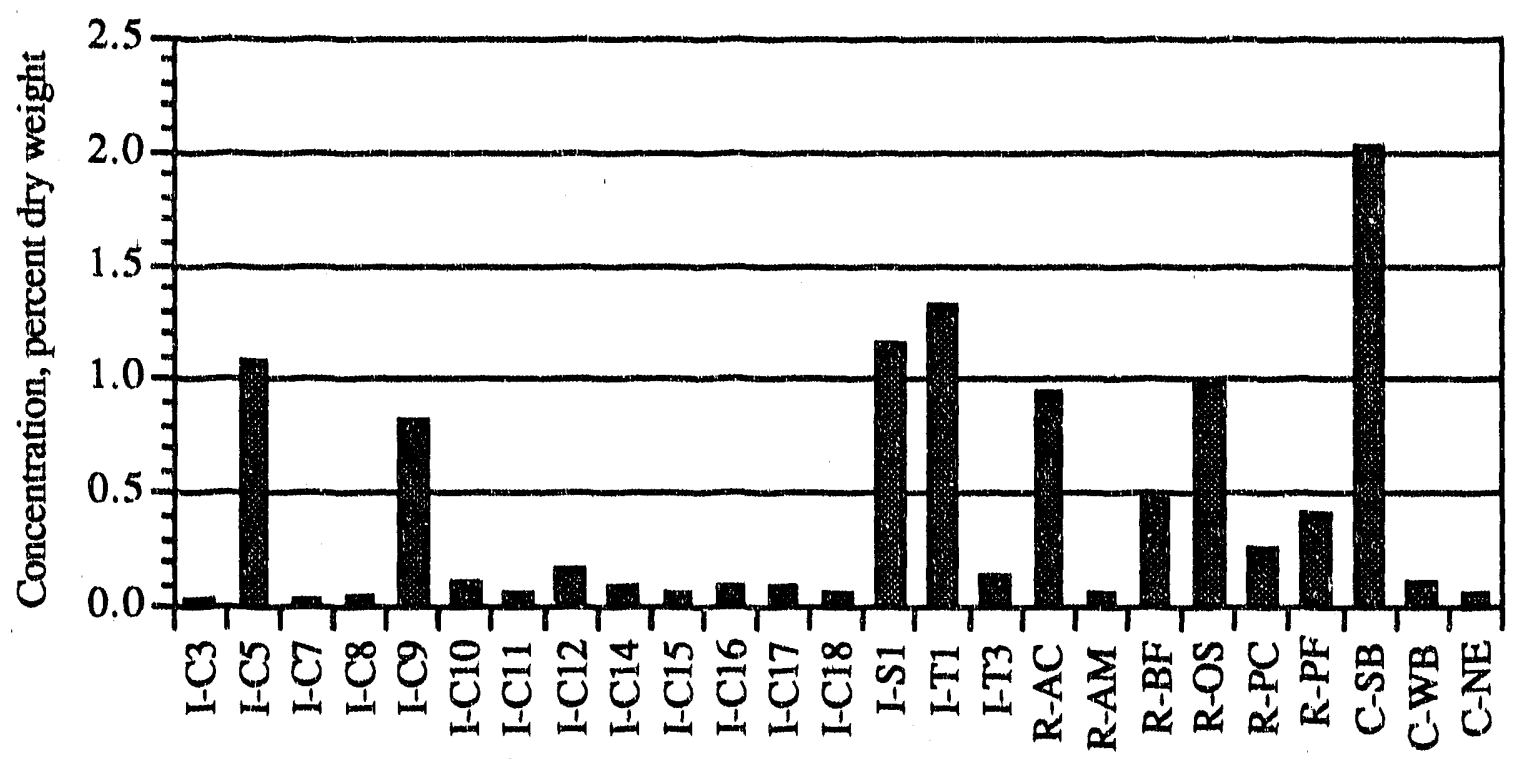

Sediment Treatment

FIGURE 3.31. Concentrations of TOC Found in Oakland Phase III A Retest Sediment Treatments

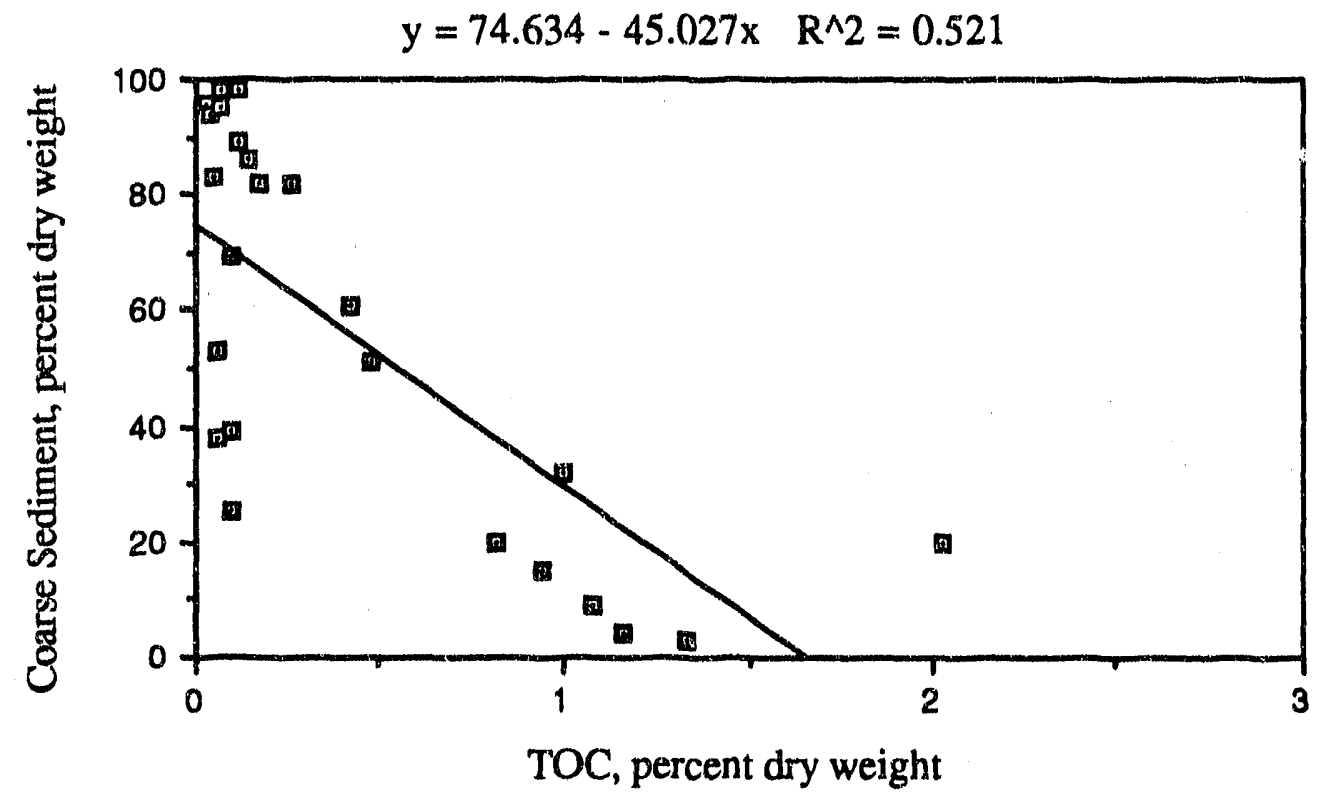

EIGURE 3.32. Linear Regression Showing the Relationship Between Grain Size and TOC in Oakland Phase III A Retest Sediment Treatments 


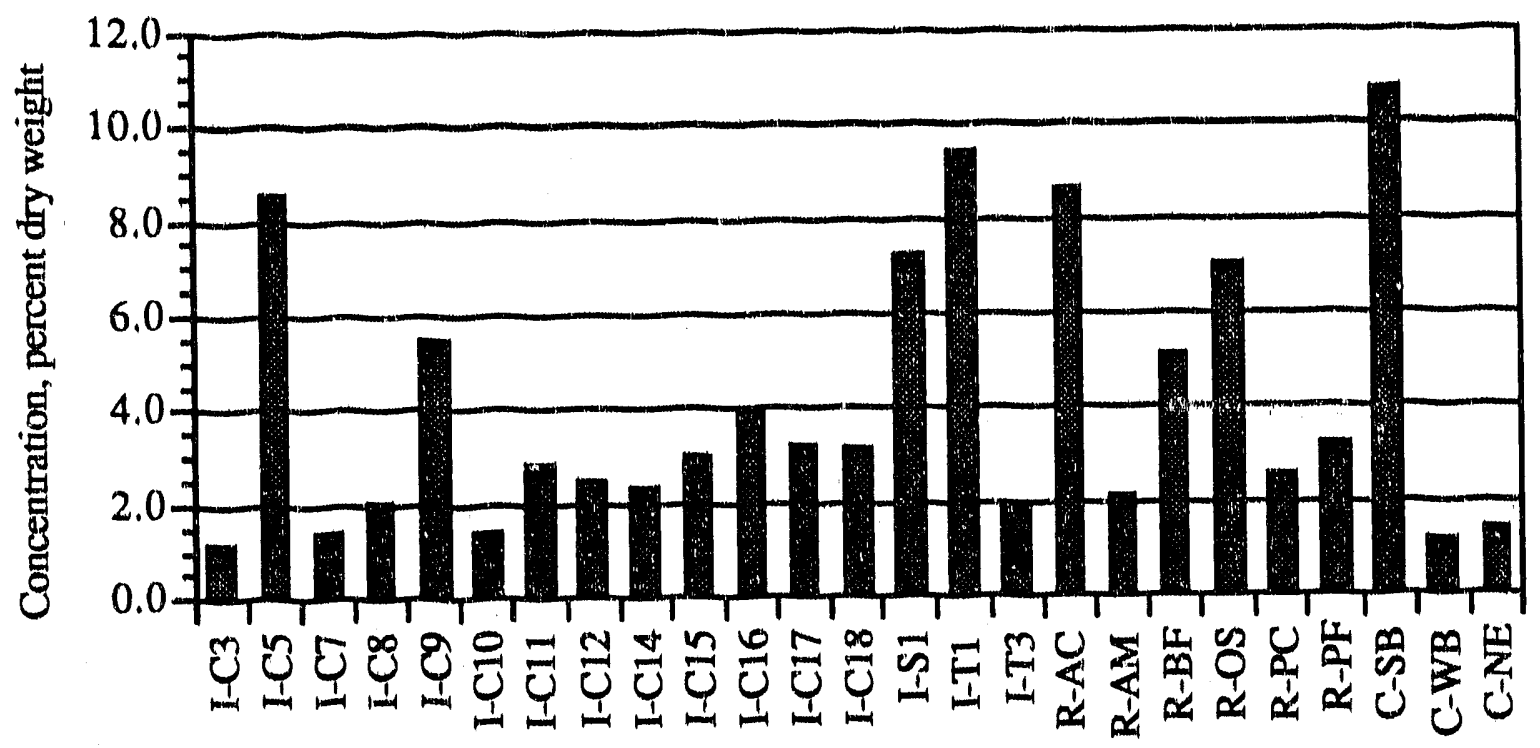

Sediment Treatment

EIGURE 3.33. Concentrations of TVS Found in Oakland Phase III A Retest Sediment Treatments

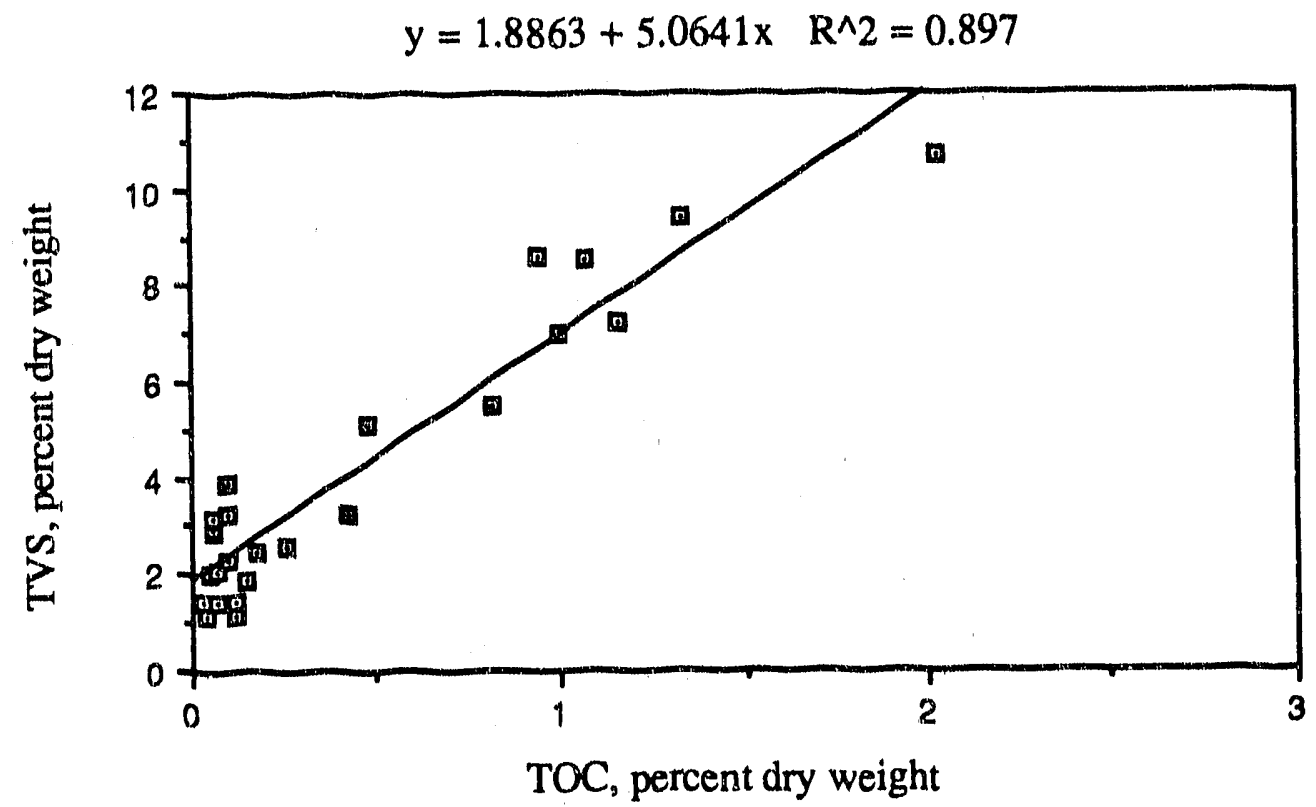

FIGURE 3.34. Linear Regression Showing the Relationship Between TOC and TVS in Oakland Phase III A Retest Sediment Treatments 


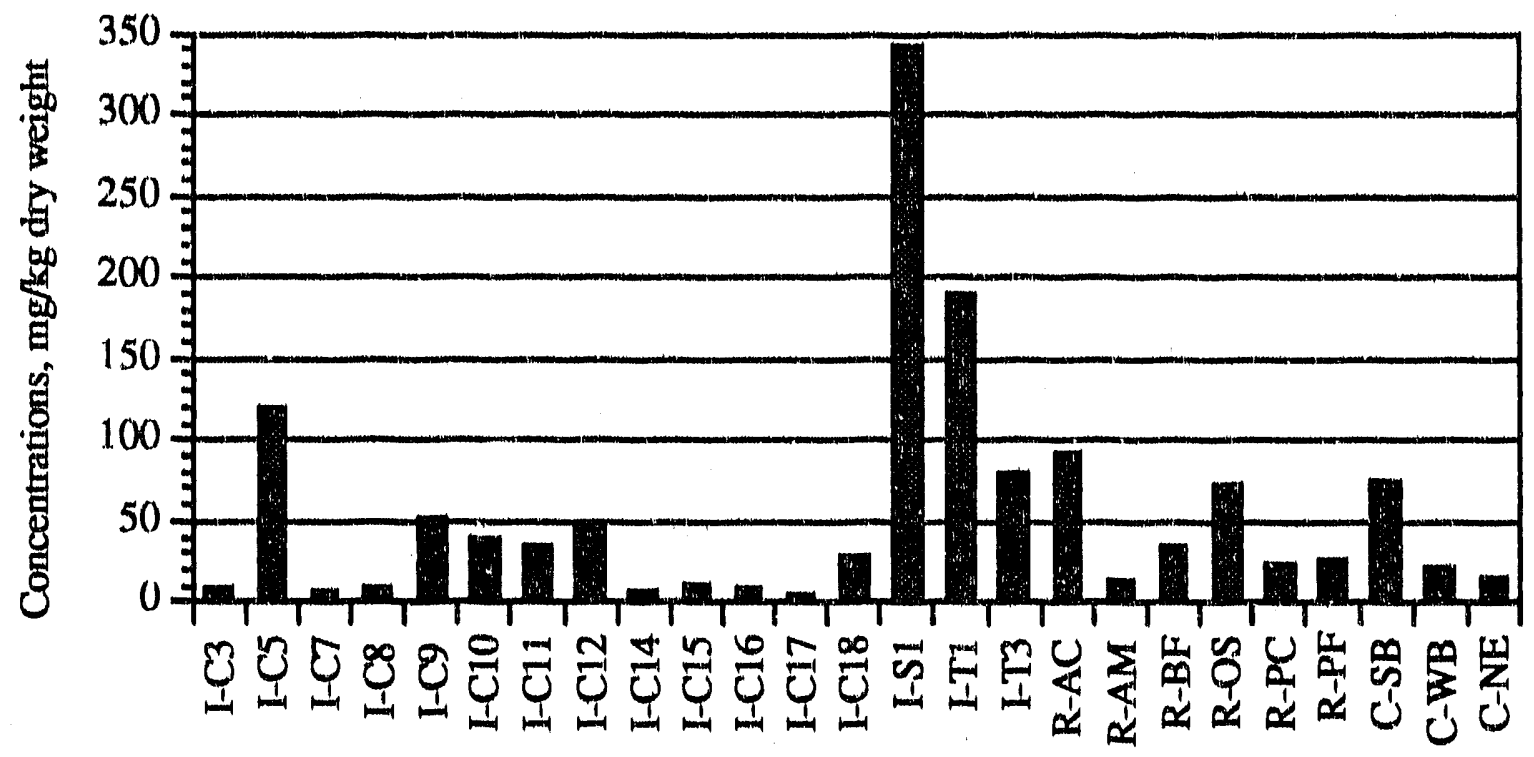

Sediment Treatment

ElGURE 3.35. Concentrations of Oil and Grease Found in Oakland Phase III A Retest Sediment Treatments

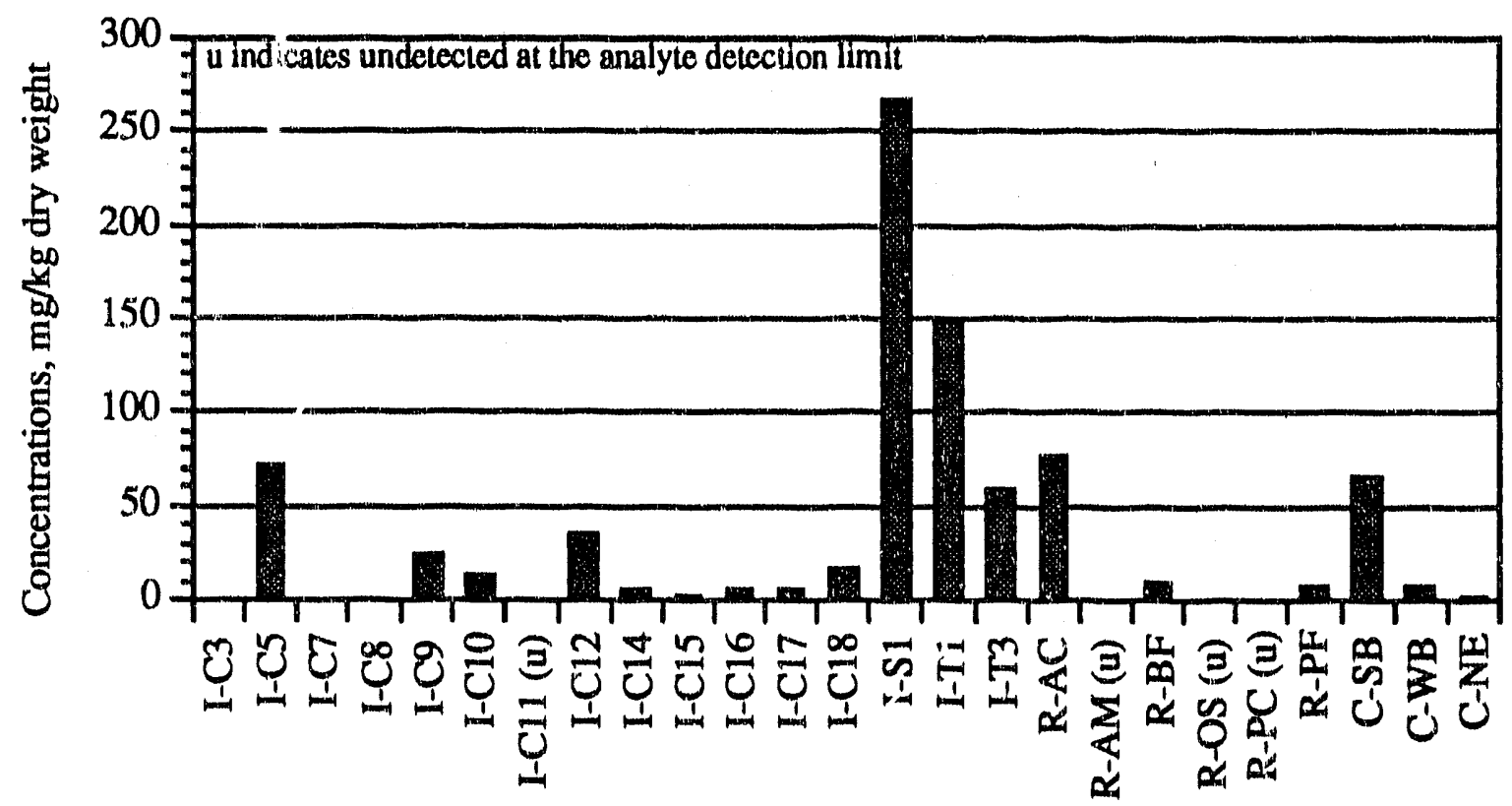

Sediment Treatment

FIGURE 3.36. Concentrations of TPH Found in Oakland Phase III A Retest Sediment Treatments 


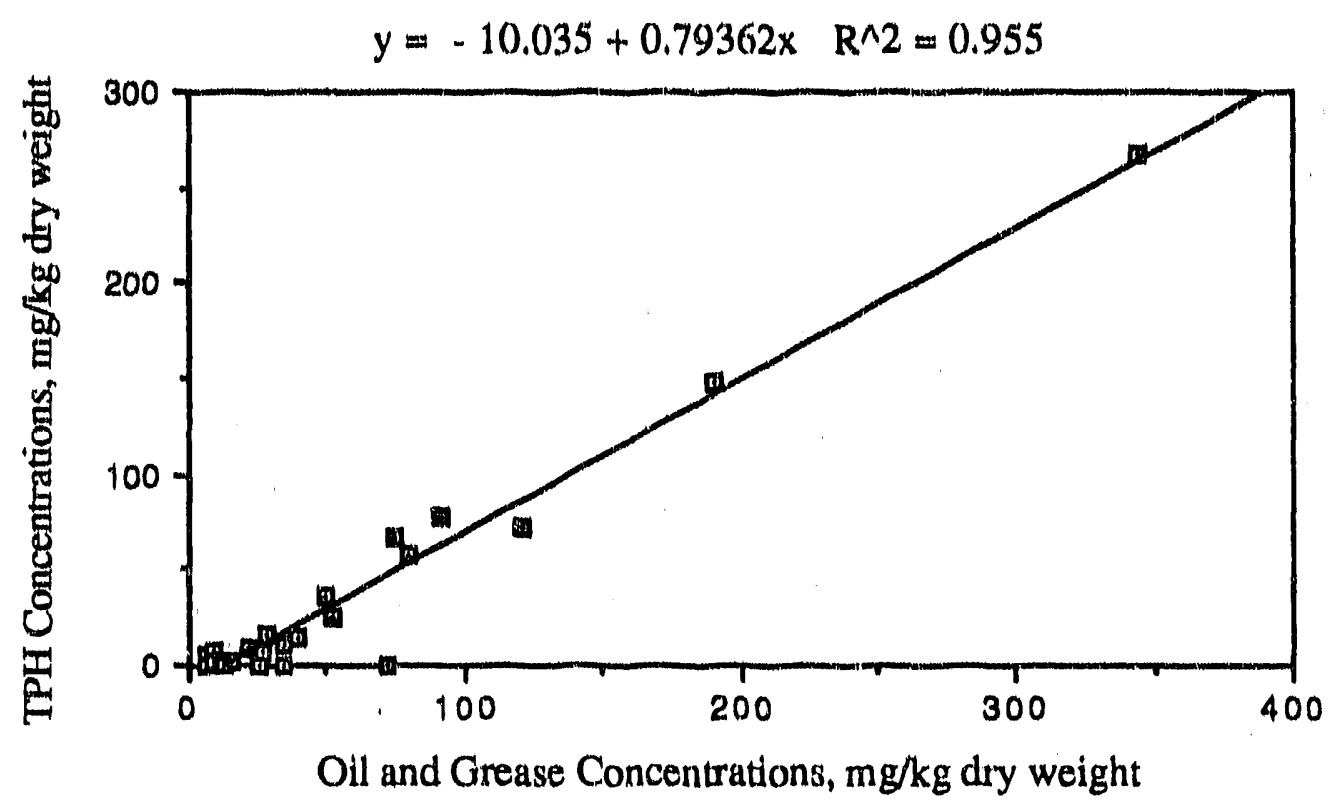

EIGURE 3.37. Linear Regression Showing the Relationship Between Oil and Grease and TPH in Oakland Phase III A Retest Sediment Treatments

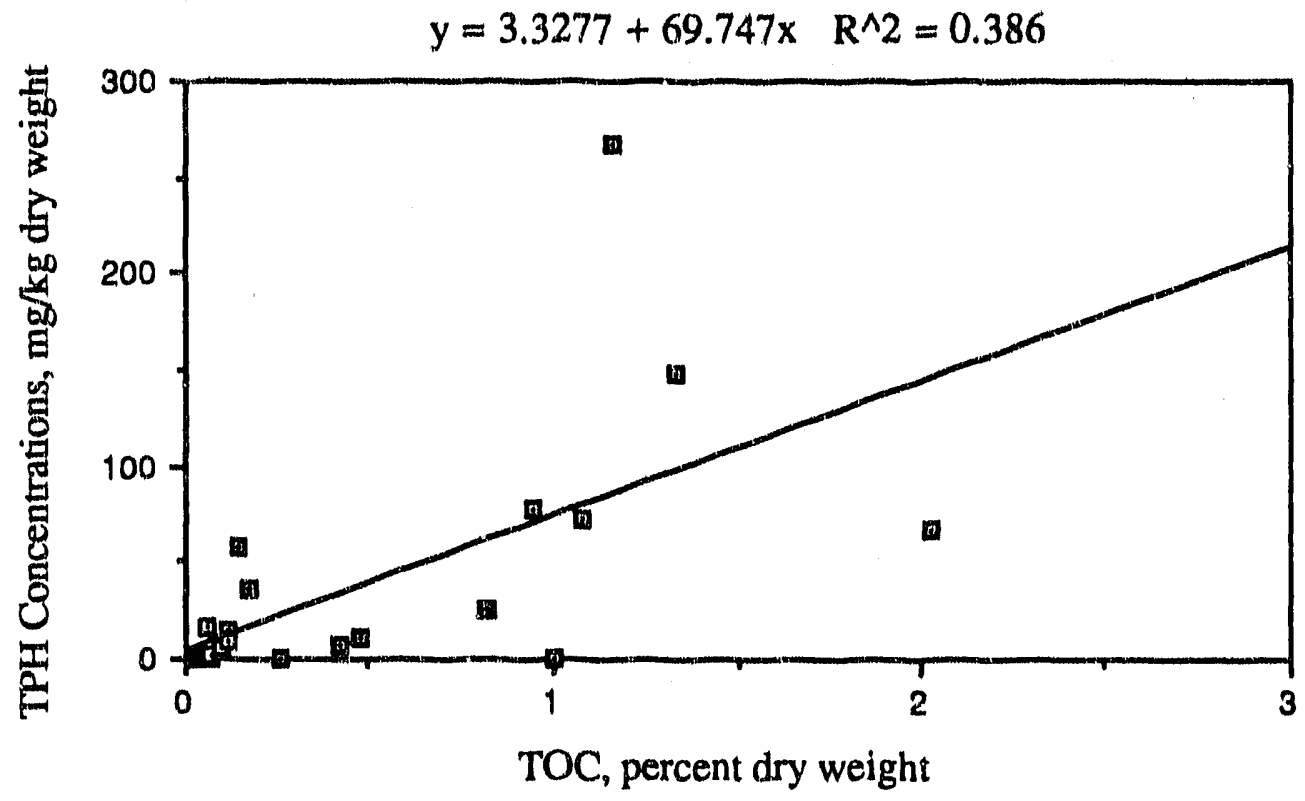

EIGURE 3.38. Linear Regression Showing the Relationship Between TPH and TOC in Oakland Phase III A Retest Sediment Treatments 


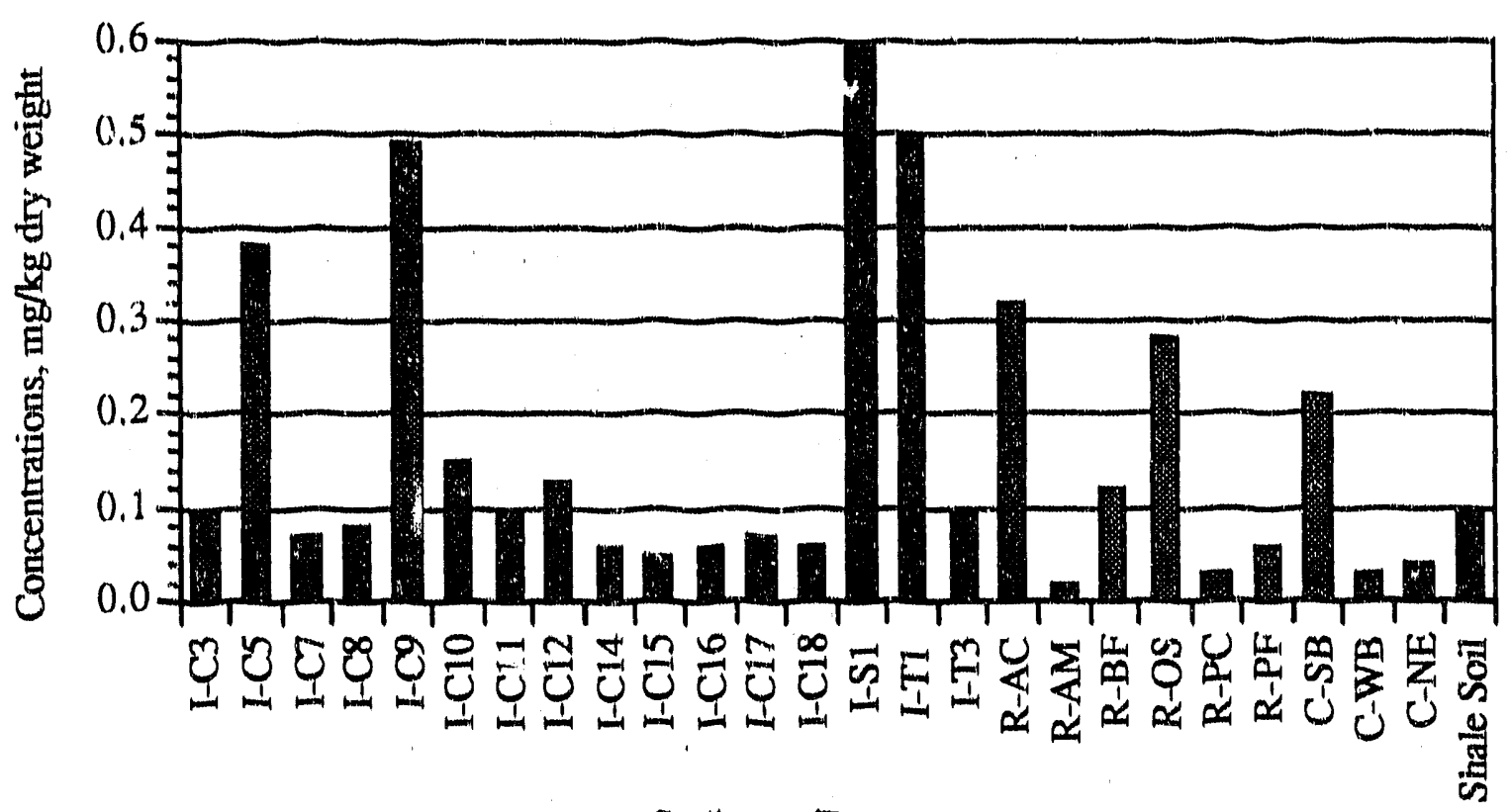

Sediment Treatment

EIGURE 3.39. Concentrations of Silver Found in Oakland Phase III A Retest Sediment Treatments

Concentrations of As found in Oakland Harbor retest sediment treatments and in typical shale soil are shown in Figure 3.40. Arsenic concentrations ranged from $2.97 \mathrm{mg} / \mathrm{kg}$ in Station I-C18 to $12.60 \mathrm{mg} / \mathrm{kg}$ in Station I-C5. A similar pattern is found in the reference and control sediment treatments, which ranged from 2.94 to $13.20 \mathrm{mg} / \mathrm{kg}$. For comparison, the average As

TAE:E 3.6. Oakland Harbor Phase III A Retest Sediment Treatments with Silver Concentrations Exceeding Those Found in Typical Shale Soil

$\begin{array}{lr}\text { Sediment } & \\ \text { Treatment } & \text { Ag Concentratio } \\ & \\ \text { Shale soil } & 0.10 \\ \text { I-C5 } & 0.38 \\ \text { I-C9 } & 0.49 \\ \text { I-C10 } & 0.15 \\ \text { I-C12 } & 0.13 \\ \text { I-S1 } & 0.59 \\ \text { I-T1 } & 0.50 \\ \text { R-AC } & 0.32 \\ \text { R-BF } & 0.12 \\ \text { R-OS } & 0.28 \\ \text { C-SB } & 0.22\end{array}$




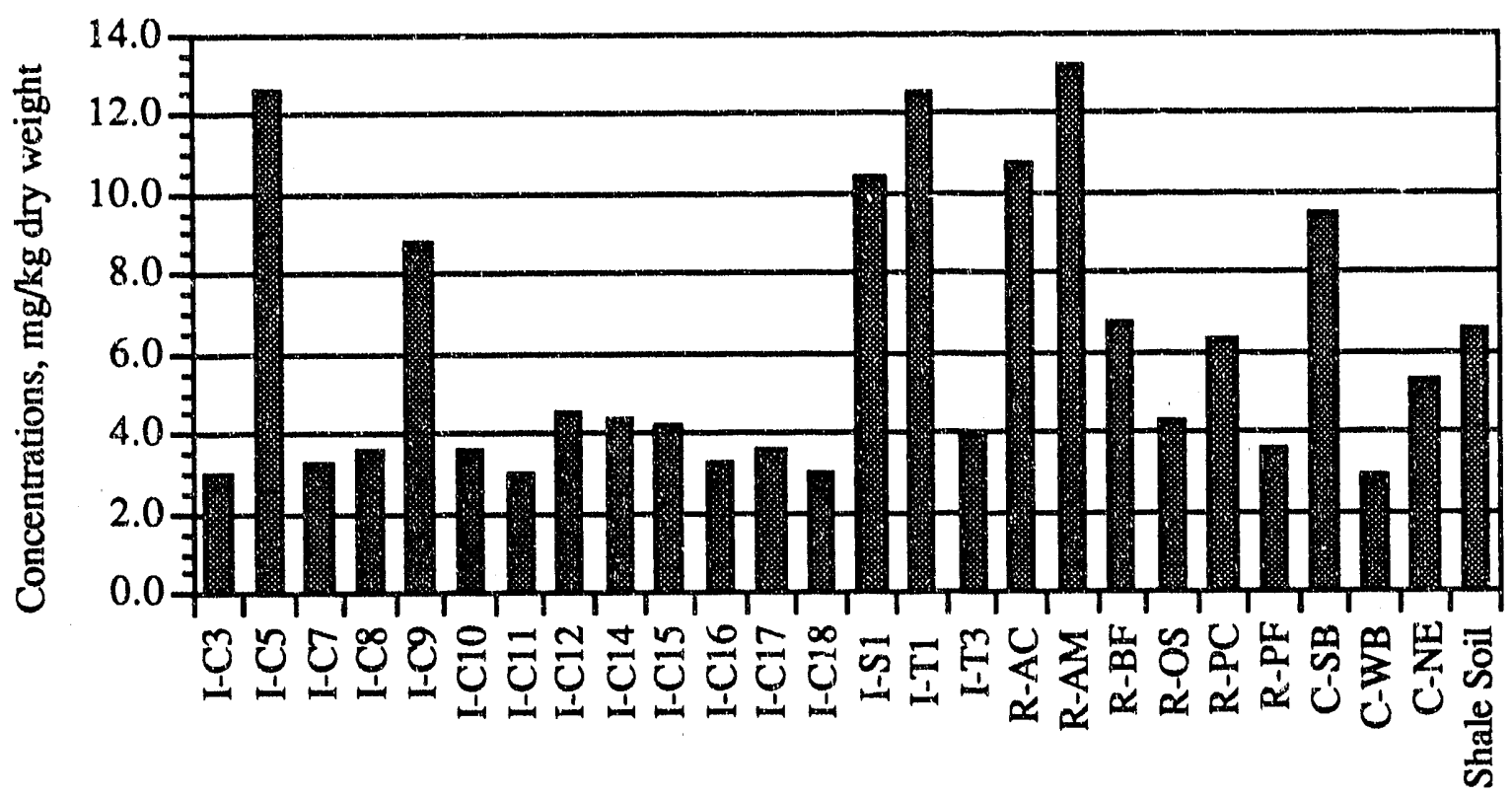

Sediment Treatment

FIGURE 3.40. Concentrations of Arsenic Found in Oakland Phase III A Retest Sediment Treatments

concentration in shale soil is $6.6 \mathrm{mg} / \mathrm{kg}$. Eight treatments (I-C5, I-C9, I-S1, I-T1, R-AC, R-AM, $\mathrm{R}-\mathrm{BF}$, and C-SB) had As concentrations exceeding shale soil levels.

Cadmium concentrations found in Oakland Harbor retest sediment treatments and in typical shale soil are shown in Figure 3.41. Concentrations ranged from 0.03 to $0.76 \mathrm{mg} / \mathrm{kg}$. Sediment treatment I-S1 had the highest $\mathrm{Cd}$ concentration, followed by I-C 9 with a concentration of $0.44 \mathrm{mg} / \mathrm{kg}$ and I-T1 with $0.35 \mathrm{mg} / \mathrm{kg}$. Cadmium concentrations in control and reference sediment treatments ranged from $0.03 \mathrm{mg} / \mathrm{kg}$ (C-NE) to $1.63 \mathrm{mg} / \mathrm{kg}$ (R-PF). Shale soil typically has a Cd concentration of $0.3 \mathrm{mg} / \mathrm{kg}$; seven sediment treatments exceeded this value, as shown in Table 3.7.

Concentrations of $\mathrm{Cr}$ found in Oakland Harbor retest sediment treatments and in typical shale soil are shown in Figure 3.42. Chromium is naturally abundant in these sediments, ranging from $140 \mathrm{mg} / \mathrm{kg}$ at I-C18 to $722 \mathrm{mg} / \mathrm{kg}$ at I-C10. The six references and three control sediment treatments had $\mathrm{Cr}$ concentrations ranging from 81 to $479 \mathrm{mg} / \mathrm{kg}$. All but one sediment treatment ( $\mathrm{C}$-NE) had $\mathrm{Cr}$ concentrations exceeding that of the typical shale soil concentration of $100 \mathrm{mg} / \mathrm{kg}$ (Krauskopf 1967). Sediment treatment I-C10, I-C12, and I-T3 had Cr concentrations at least five times greater than that of shale soil. 


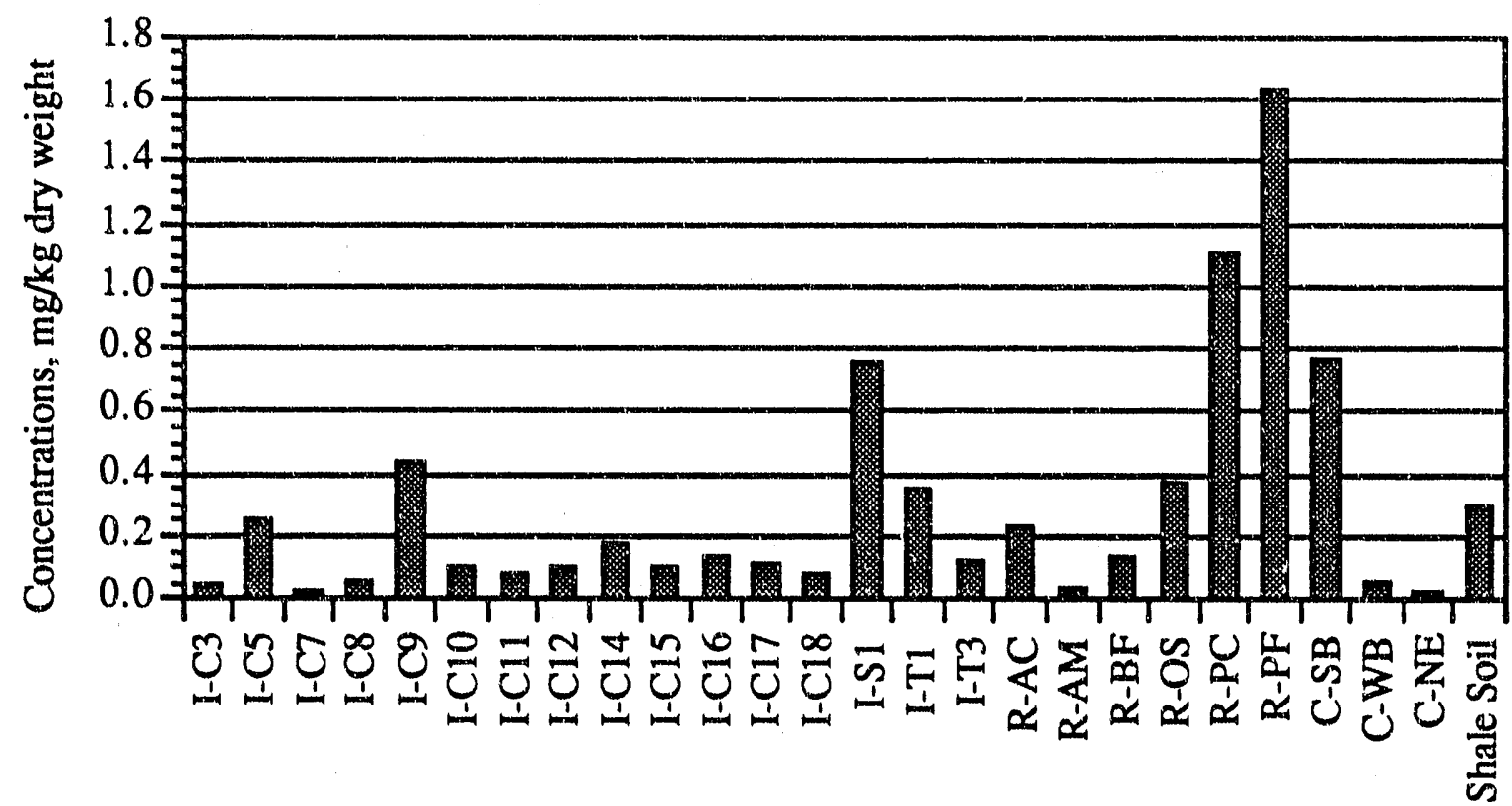

Sediment Treatment

EIGURE 3.41. Concentrations of Cadmium Found in Oakland Phase III A Retest Sediment Treatments

Concentrations of $\mathrm{Cu}$ found in Oakland Harbor retest sediment treatments and in typical shale soil are shown in Figure 3.43. Sediment treatment $1-\mathrm{C} 3$ had the lowest $\mathrm{Cu}$ concentration at $11.10 \mathrm{mg} / \mathrm{kg}$ and $\mathrm{I}-\mathrm{S} 1 \mathrm{had}$ the highest concentration at $86.10 \mathrm{mg} / \mathrm{kg}$ (an eightfold difference). The reference and control sediment treatments ranged from $8.0 \mathrm{mg} / \mathrm{kg}(\mathrm{C}-\mathrm{NE})$ to $56.1 \mathrm{mg} / \mathrm{kg}(\mathrm{R}-\mathrm{AC})$. Four sediment treatments, I-C5, I-C9, I-S1, and I-T1, had Cu concentrations greater than 57 $\mathrm{mg} / \mathrm{kg}$, the concentration seen in typical shale soil (Krauskopf 1967).

TABLE 3.7. Oakland Harbor Phase III A Restest Sediment Treatments with Cadmium Concentrations Exceeding Those Found in Typical Shale Soil

\begin{tabular}{lr} 
Sediment & \\
Treatment & Cd Concentratio \\
\hline & \\
Shale soil & 0.30 \\
I-C9 & 0.44 \\
I-S1 & 0.76 \\
I-T1 & 0.35 \\
R-OS & 0.38 \\
R-PC & 1.11 \\
R-PF & 1.63 \\
C-SB & 0.77
\end{tabular}




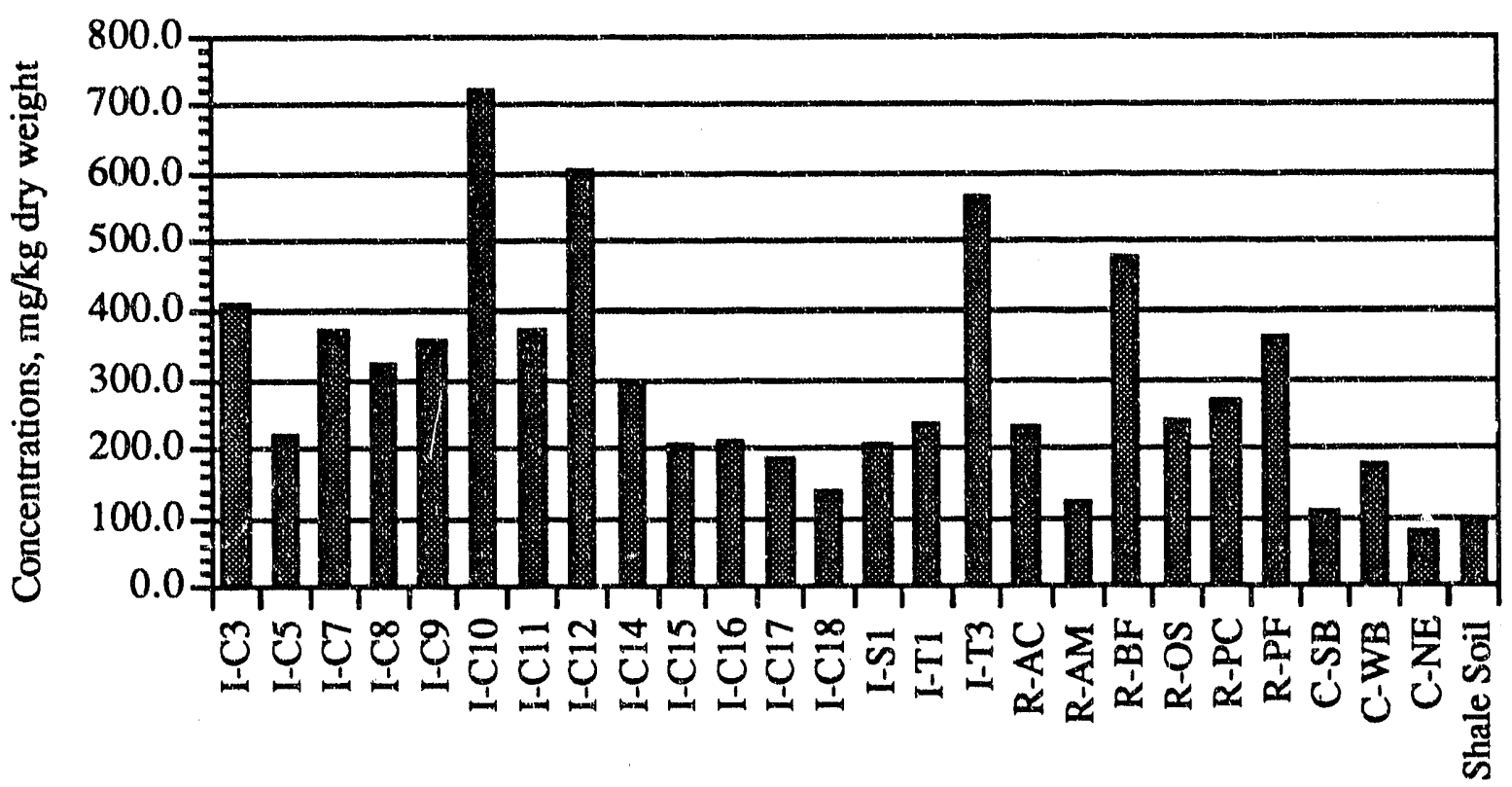

Sediment Treatment

FIGURE 3,42. Concentrations of Chromium Found in Oakland Phase III A Retest Sediment Treatments

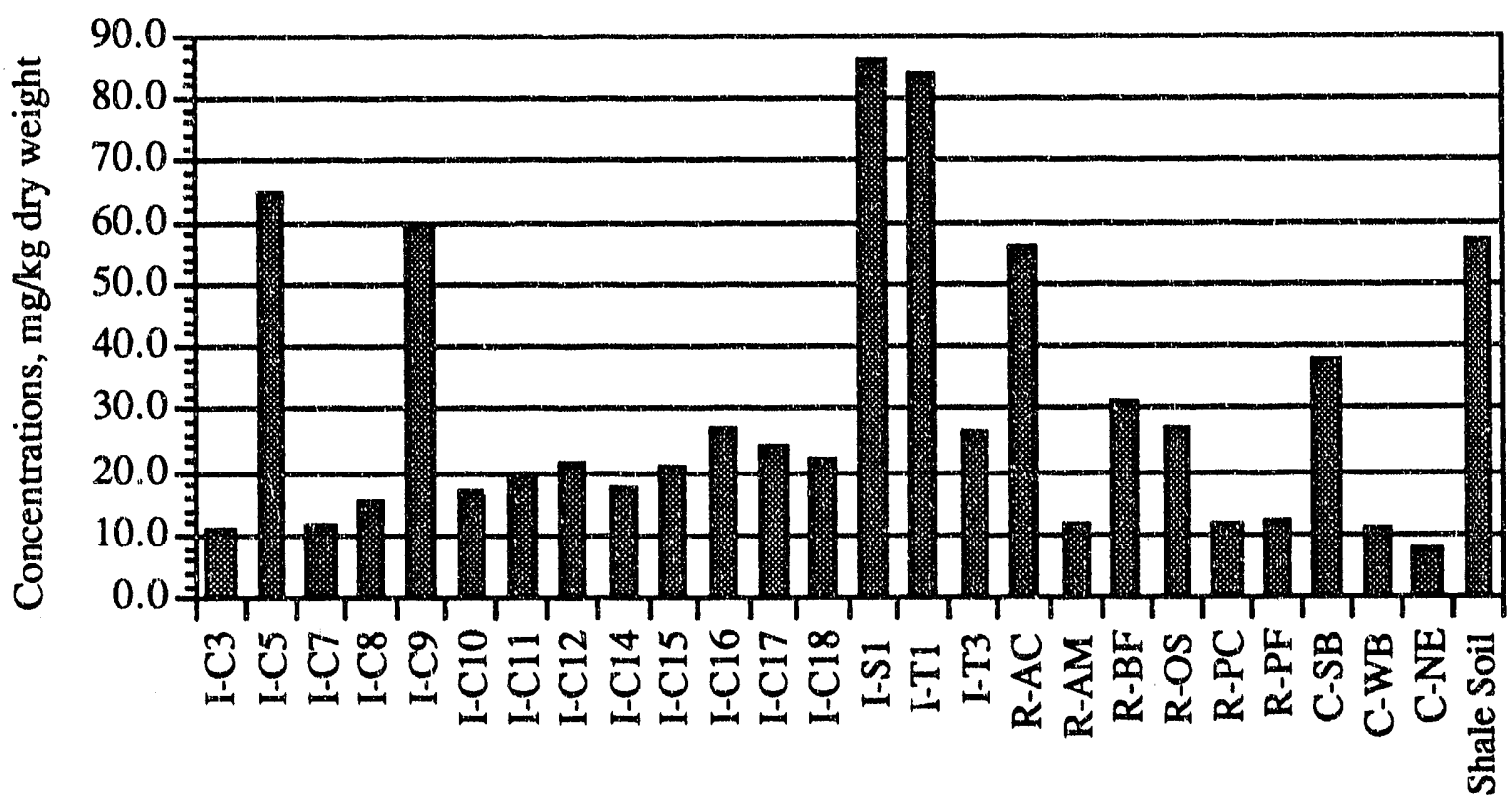

Sediment Treatment

FIGURE 3.43. Concentrations of Copper Found in Oakland Phase III A Retest Sediment Treatments 
Concentrations of $\mathrm{Hg}$ found in Oakland Harbor retest sediment treatments and in typical shale soil are presented graphically in Figure 3.44. Mercury concentrations from Oakland Harbor sediments ranged from 0.007 to $0.812 \mathrm{mg} / \mathrm{kg}$. Sediment treatment I-S1 had the highest concentration $(0.812 \mathrm{mg} / \mathrm{kg})$ followed by I-T1 $(0.476 \mathrm{mg} / \mathrm{kg})$, I-C5 $(0.359 \mathrm{mg} / \mathrm{kg})$, and I-C 9 $(0.331 \mathrm{mg} / \mathrm{kg})$. The lowest $\mathrm{Hg}$ concentration was found in C-WB $(0.009 \mathrm{mg} / \mathrm{kg})$. The typical shale soil concentration of $\mathrm{Hg}$ is $0.4 \mathrm{mg} / \mathrm{kg}$. Two sediment treatments, I-S1 and I-T1, had values exceeding $0.4 \mathrm{mg} / \mathrm{kg}$.

Concentrations of Ni found in Oakland Harbor retest sediment treatments and in typical shale soil are presented graphically in Figure 3.45. Nickel concentrations ranged from $34.1 \mathrm{mg} / \mathrm{kg}$ (I-C3) to $126.1 \mathrm{mg} / \mathrm{kg}$ (I-S1). Nickel concentrations for reference and control sediment treatments ranged from 22.7 to $104 \mathrm{mg} / \mathrm{kg}$. Five sediment treatments (I-C5, I-C9, I-S1, I-T1, and $\mathrm{R}-\mathrm{AC}$ ) had Ni concentrations that exceeded the typical shale soil concentration of $95 \mathrm{mg} / \mathrm{kg}$.

Concentrations of $\mathrm{Pb}$ found in Oakland Harbor retest sediment treatments and in typical shale soil are presented graphically in Figure 3.46. Lead concentrations ranged from $5.4 \mathrm{mg} / \mathrm{kg}$ (I-C7) to $65.3 \mathrm{mg} / \mathrm{kg}$ (I-S1). Lead concentrations in reference and control sediment treatments ranged from $3.5 \mathrm{mg} / \mathrm{kg}$ to $24.40 \mathrm{mg} / \mathrm{kg}$. Five sediment treatments (I-C5, I-C9, I-S1, I-T1, and $\mathrm{R}-\mathrm{AC}$ ) had concentrations that exceeded the typical shale soil $\mathrm{Pb}$ concentration of $20 \mathrm{mg} / \mathrm{kg}$ (Krauskopf 1967).

Selenium (Se) was detected in 5 of the 16 Oakland Harbor sediment treatments (I-C5, I-C9, I-C15, I-S1, and I-T1). Selenium concentrations ranged from undetected (with a detection limit of $0.07 \mathrm{mg} / \mathrm{kg}$ ) to $0.38 \mathrm{mg} / \mathrm{kg}$ at sediment treatment I-S1. Concentrations of Se in the reference and control sediment treatments ranged from undetected at R-AM, R-PC, C-WB, and C-NE, to $1.11 \mathrm{mg} / \mathrm{kg}$ at R-OS. Two sediment treatments (C-SB and R-OS) had Se concentrations above $0.60 \mathrm{mg} / \mathrm{kg}$, the Se concentration found in typical shale soil.

Concentrations of $\mathrm{Zn}$ found in Oakland Harbor retest sediment treatments and in typical shale soil are presented graphically in Figure 3.47. Zinc concentrations ranged from $27.6 \mathrm{mg} / \mathrm{kg}$ (I-C3) to $222.0 \mathrm{mg} / \mathrm{kg}$ (I-S1). Reference and control sediment treatment concentrations of $\mathrm{Zn}$ ranged from $22.0 \mathrm{mg} / \mathrm{kg}$ (C-NE) to $115.3 \mathrm{mg} / \mathrm{kg}$ (R-AC). Eight sediment treatments had $\mathrm{Zn}$ concentrations greater than $80 \mathrm{mg} / \mathrm{kg}$, the typical $\mathrm{Zn}$ concentration found in shale soil (Krauskopf 1967), as shown in Table 3.8. 


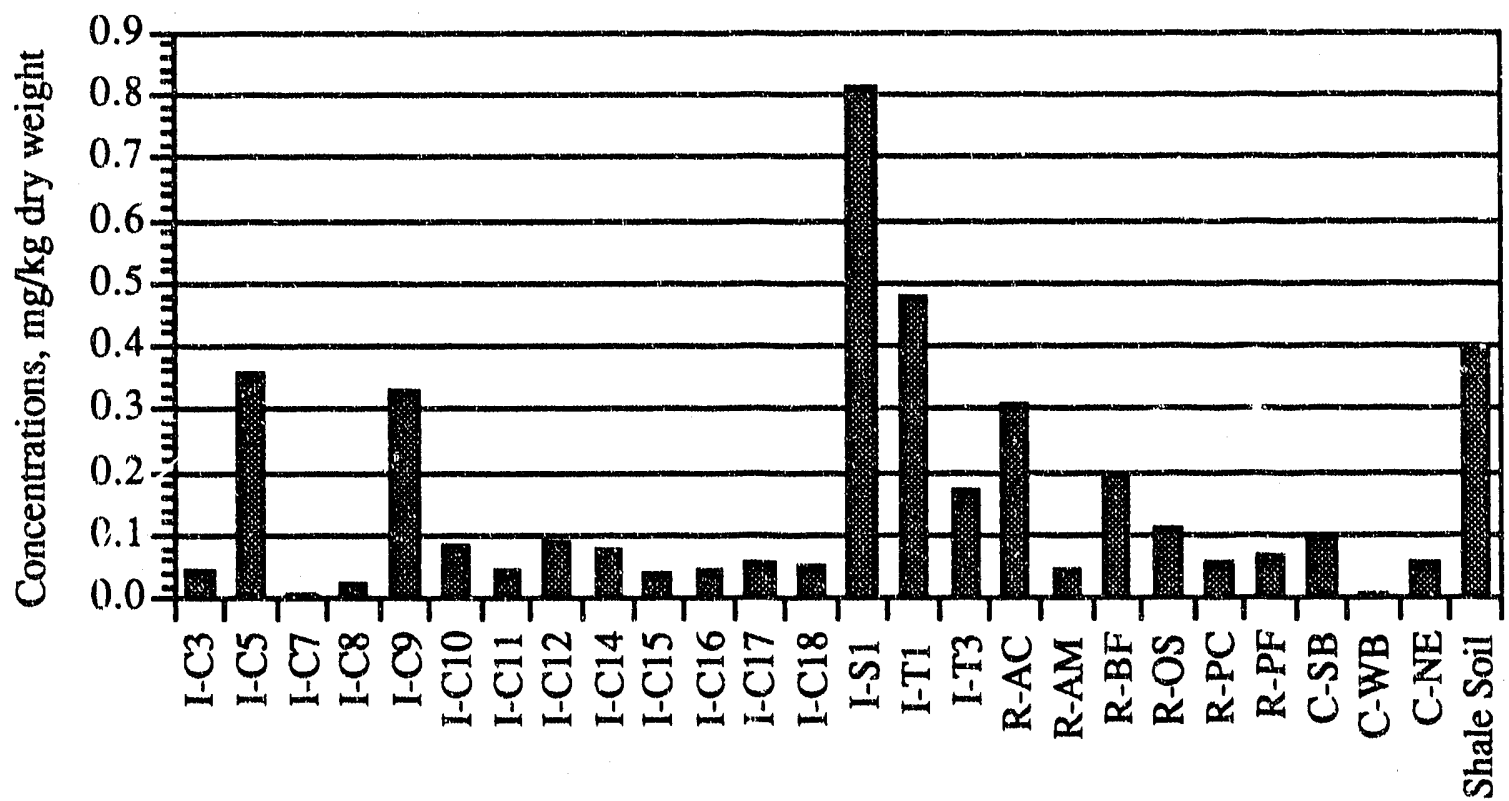

Sediment Treatment

FIGURE 3.44. Concentrations of Mercury Found in Oakland Phase III A Retest Sediment Treatments

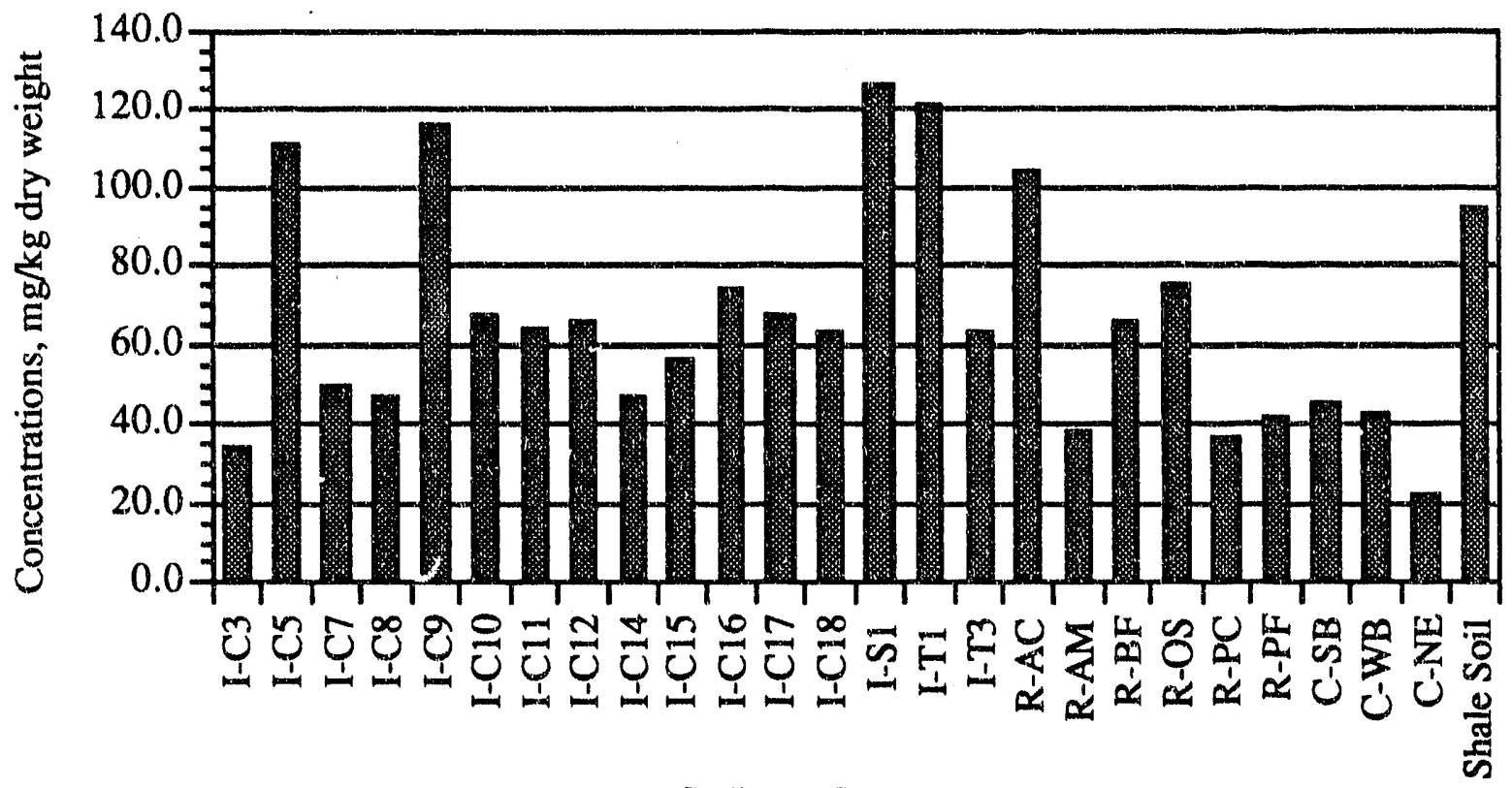

Sediment Treatment

FIGURE 3,45. Concentrations of Nickel Found in Oakland Phase III A Retest Sediment Treatments 


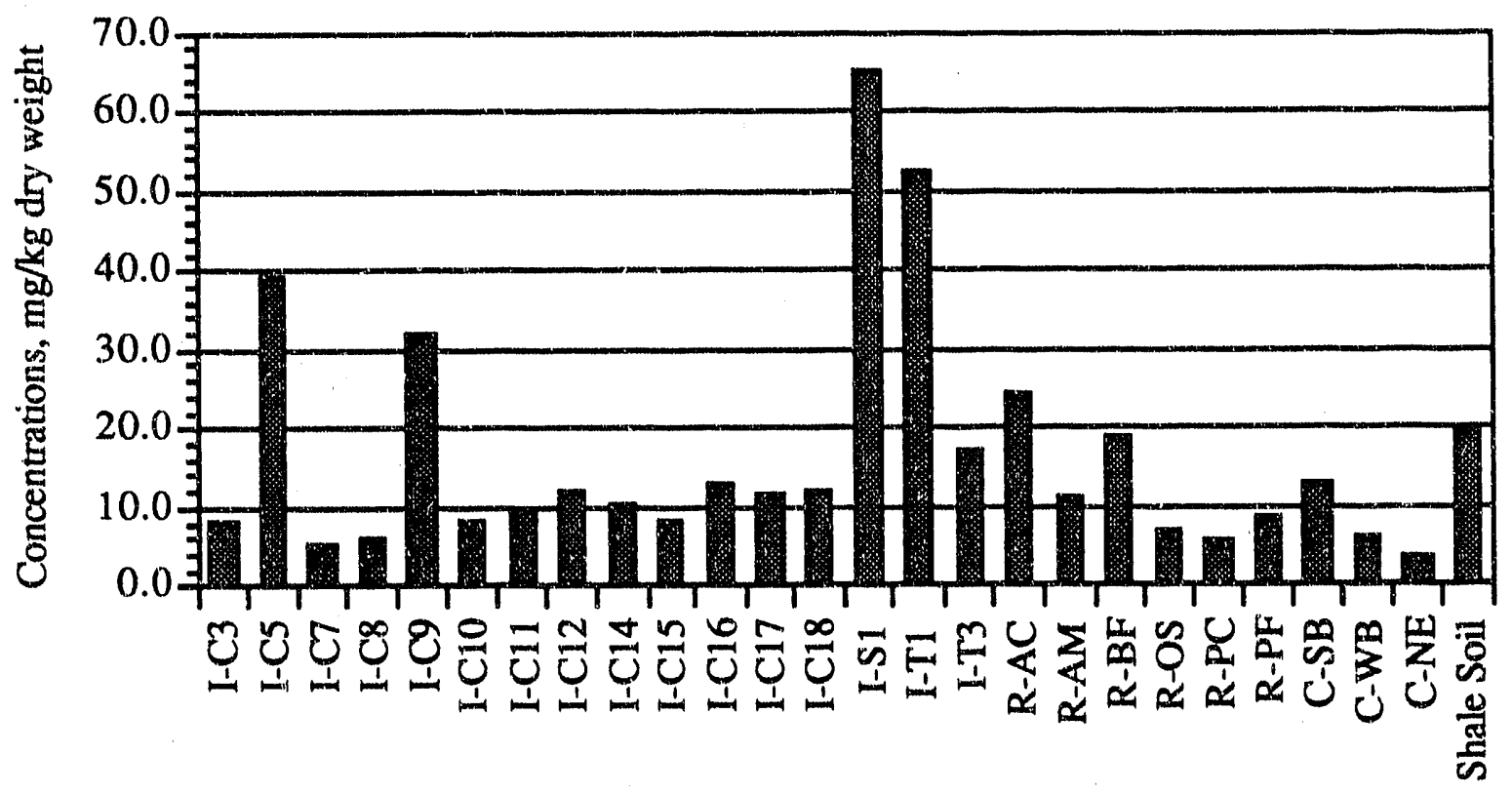

Sediment Treatment

FIGURE 3.46. Concentrations of Lead Found in Oakland Phase III A Retest Sediment Treatments

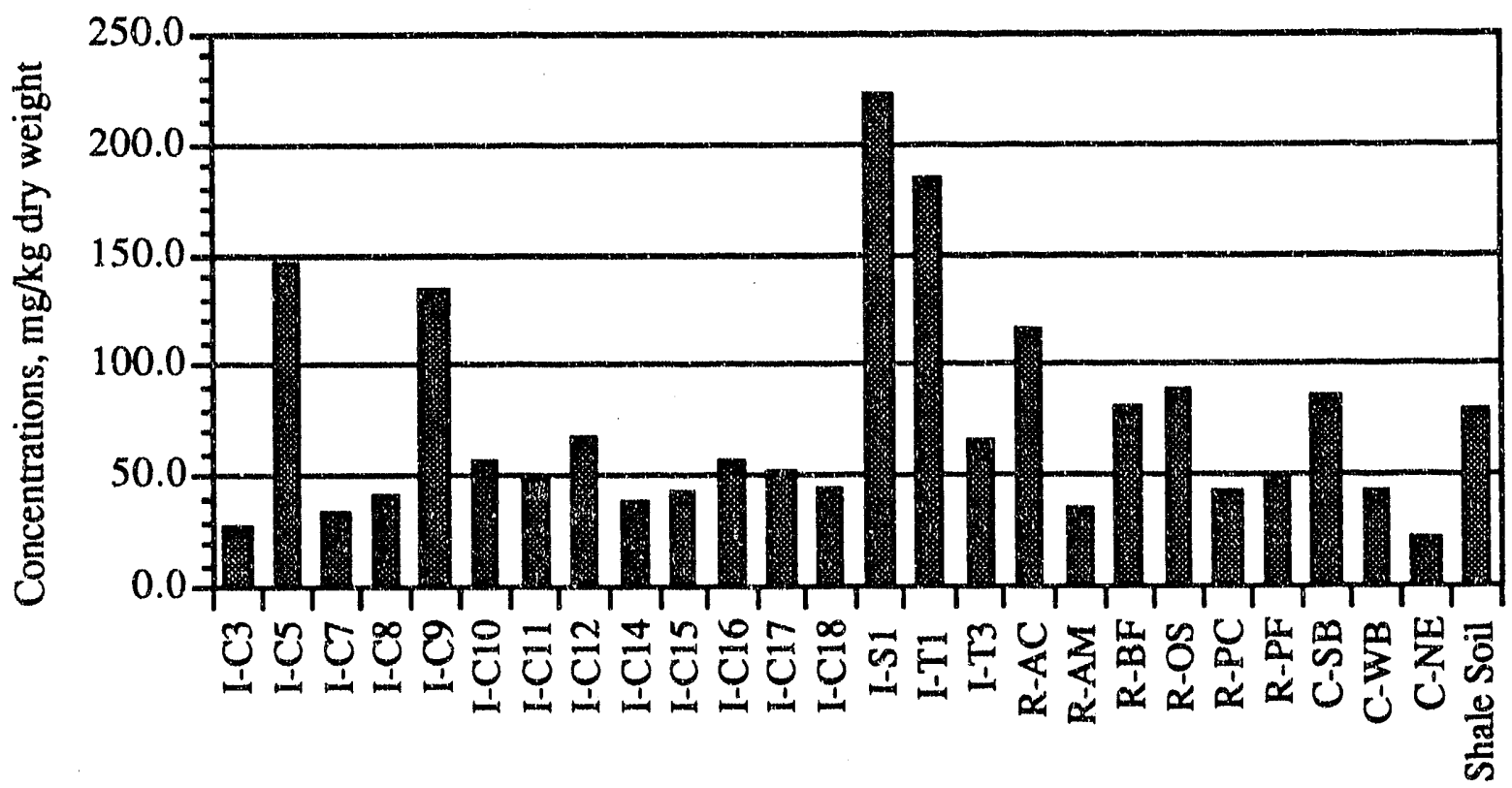

Sediment Treatment

FIGURE 3.47. Concentrations of Zinc Found in Oakland Phase III A Retest Sediment Treatments 
TABLE 3.8. Oakland Harbor Phase III A Retest Sediment Treatments with Zinc Concentrations Exceeding Those Found in Typical Shale Soil

$\begin{array}{lr}\text { Sediment } & \\ \text { Treatment } & \text { Zinc Concentra } \\ \text { Shale Soil } & \\ \text { I-C5 } & 80.0 \\ \text { I-C9 } & 146.4 \\ \text { I-S1 } & 133.6 \\ \text { I-T1 } & 222.0 \\ \text { R-AC } & 183.6 \\ \text { R-BF } & 115.3 \\ \text { R-OS } & 80.7 \\ \text { C-SB } & 88.7 \\ & 84.9\end{array}$

\subsubsection{Chlorinated Pesticides and PCBs (Retest)}

Results of analysis of the Oakland Harbor Phase IIl A retest sediment trearments for chlorinated pesticides are presented in Volume 2, Appendix D, Table D.9. Pesticide data are reported in $\mu \mathrm{g} / \mathrm{kg}$ dry weight. Low concentrations $(5.0$ to $8.0 \mu \mathrm{g} / \mathrm{kg}$ ) of 4,4'-DDD, 4,4'-DDE, and dieldrin were detected in two of the three replicate analyses of sediment treatment I-C5. The $4,4^{\prime}$-DDT was detected at $3.2 \mu \mathrm{g} / \mathrm{kg}$ in only one sediment treatment, I-C10. No pesticides were detected in any of the other sediment treatments. PC.Bs (Volume 2, Appendix D, Table D.7) as Aroclor 1242, 1254, and 1260 were found in four of the test sediment treatments, four of the reference sediment treatments, and two of the control sediment treatments as shown in Table 3.9. Aroclor 1254 was the most frequently detected PCB in the sediment treatments. Concentrations of Aroclor 1254 are shown graphically in Figure 3.48.

\subsubsection{PAHs (Retest)}

Results of anaiysis of Oakland Harbor Phase III A sediment treatments for total LPAH compounds are shown in Figure 3.49; analytical results for total HPAH compounds are presented in Figure 3.50. Data for individual LPAH compounds are presented in Volume 2, Appendix D, Table D.2, which is also a summary of data for total LPAH and HPAH. Data for individual HPAH compounds are in Volume 2, Appendix D, Table D.3. The highest total LPAH concentrations were found in sediment treatments R-AC $(979.07 \mu \mathrm{g} / \mathrm{kg}), \mathrm{I}-\mathrm{S} 1(606.26 \mu \mathrm{g} / \mathrm{kg})$, and I-T1 $(259.52 \mu \mathrm{g} / \mathrm{kg})$. The same three sediment treatments also had the highcst concentrations of total HPAH: I-S1 $(5773.72 \mu \mathrm{g} / \mathrm{kg})$, I-T1 $(3292.89 \mu \mathrm{g} / \mathrm{kg})$, and R-AC (2004.83 $\mu \mathrm{g} / \mathrm{kg})$. Figure 3.51 shows the total PAH concentrations in all sediment treatments. Note that HPAHs contibute the greatest percentage to the total PAH level. The percentage of LPAH and HPAH making up the 
TABLE 3.9. PCB Concentrations Found in Oakland Phase III A Retest Sediment Treatments

Sediment

Treatment

I-C5

I-S1

I-T1

I-T3

R-BF

R-OS

R-FC

$\mathrm{R}-\mathrm{PF}$

C-SB

C.WB

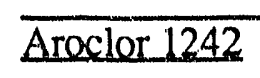

ND

ND

ND

150

$\mathrm{ND}$

ND

ND

$\mathrm{ND}$

ND

ND
Concentration $(\mu / \mathrm{kg})$ Aroclor 1254

72.3

97.0

ND

250.0

51.0

260.0

73.0

52.0

150.0

110.0
Aroclor 1260

ND

ND

140.0

ND

ND

ND

ND

ND

ND

45.0

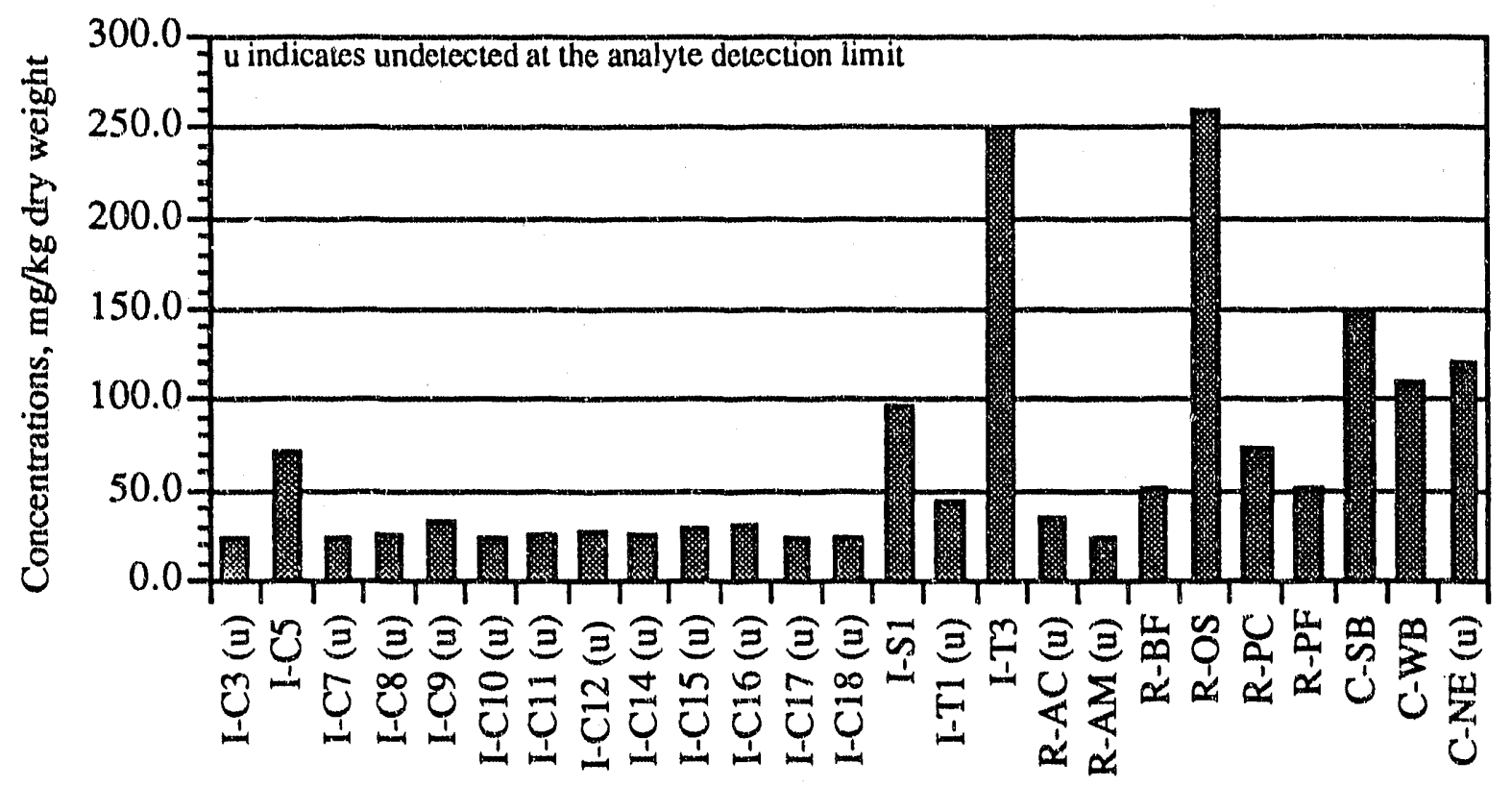

Sediment Treatment

FIGURE 3 48. Concentrations of Aroclor 1254 Found in Oakland Phase III A Retest Sediment Treatments

\subsubsection{Butyltins (Retest)}

The results of analysis of Oakland Harbor Phase III A retest sediment treatments for butlytins are presented graphically in Figure 3.52 (monobutyltin), Figure 3.53 (dibutyltin), and 


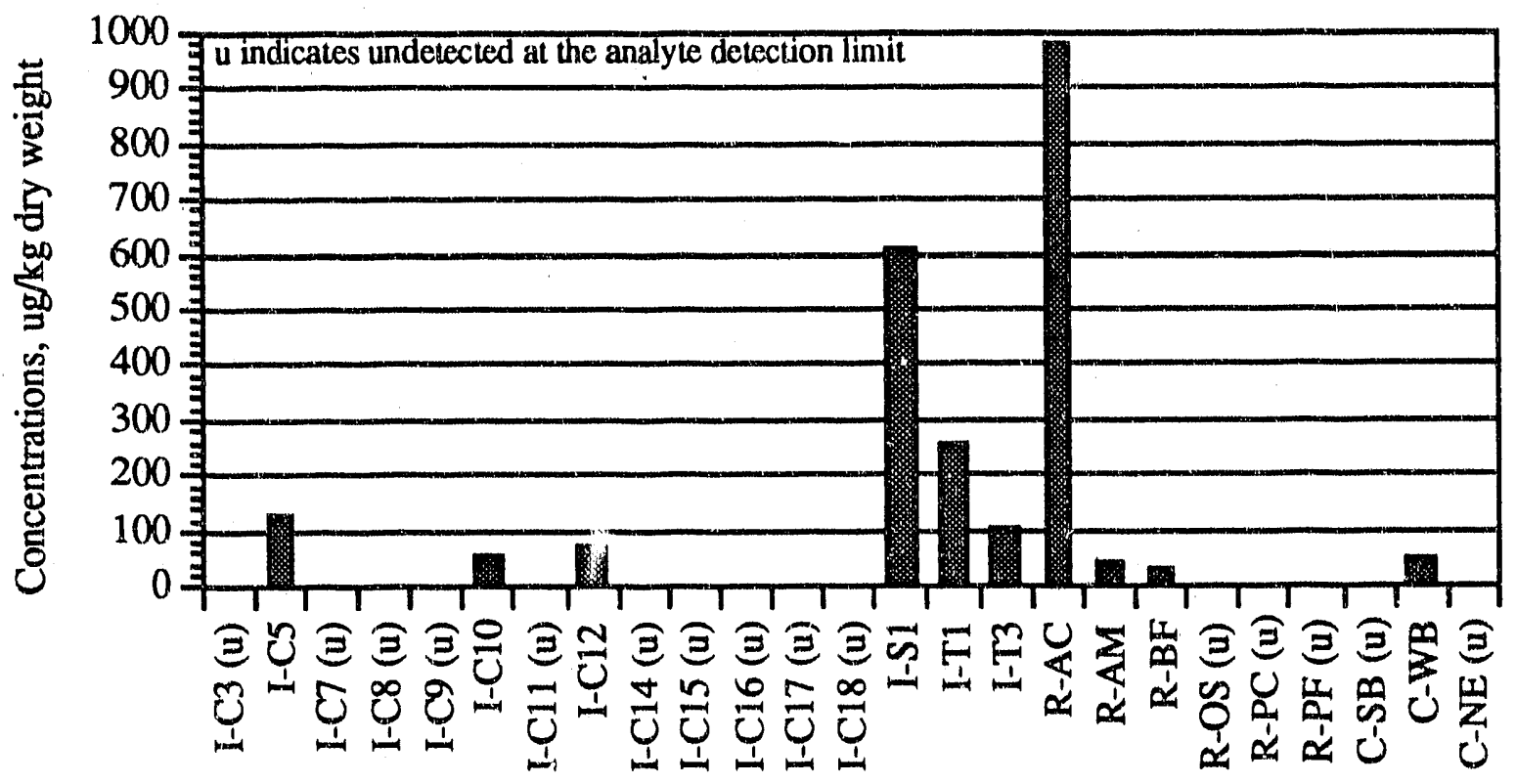

Sediment Treatment

FIGURE 3.49. Concentrations of LPAH Found in Oakland Phase III A Retest Sediment Treatments

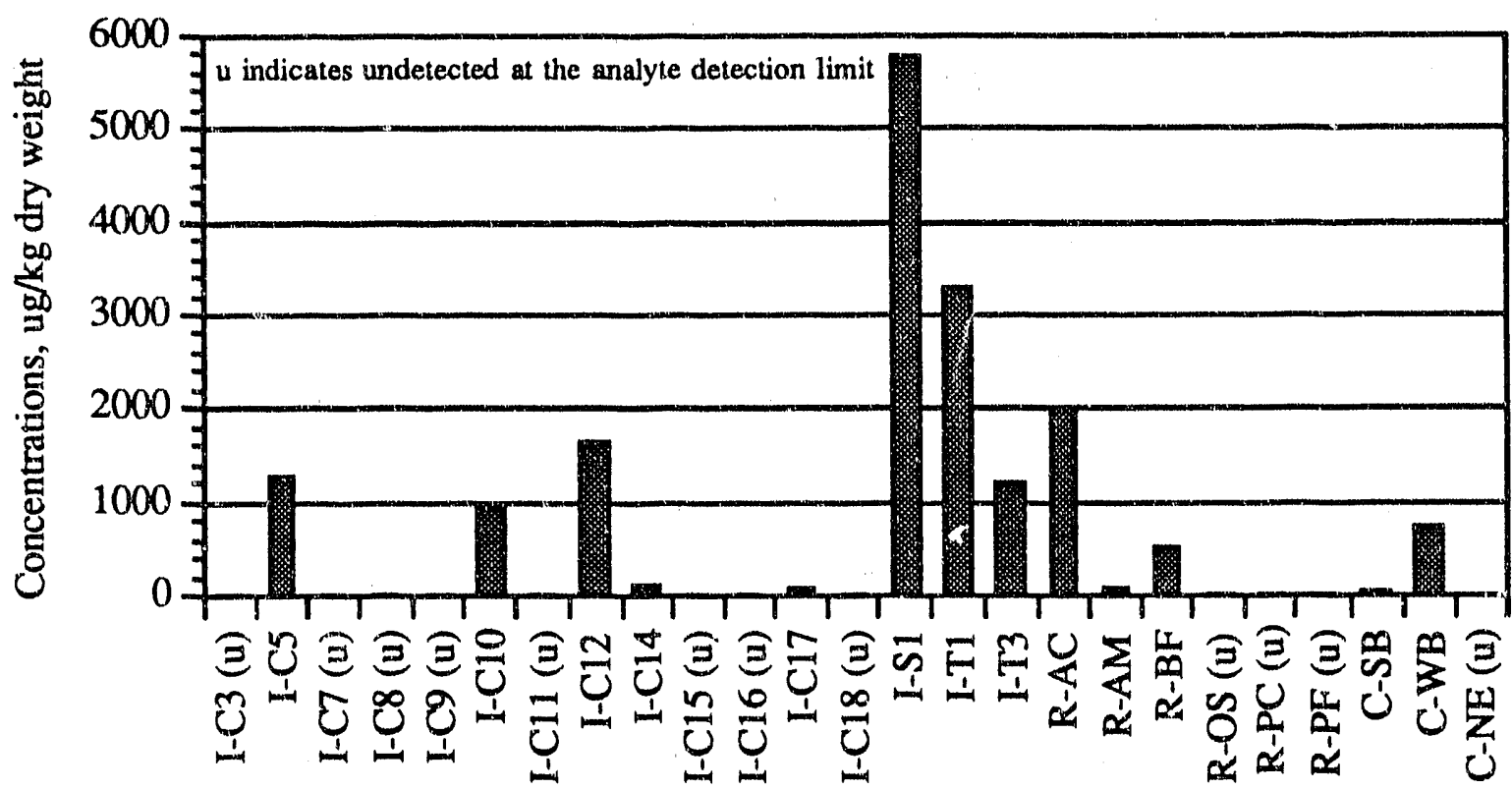

Sediment Treatment

FIGURE 3.50. Concentrations of HPAH Found in Oakland Phase III A Retest Sediment Treatments 


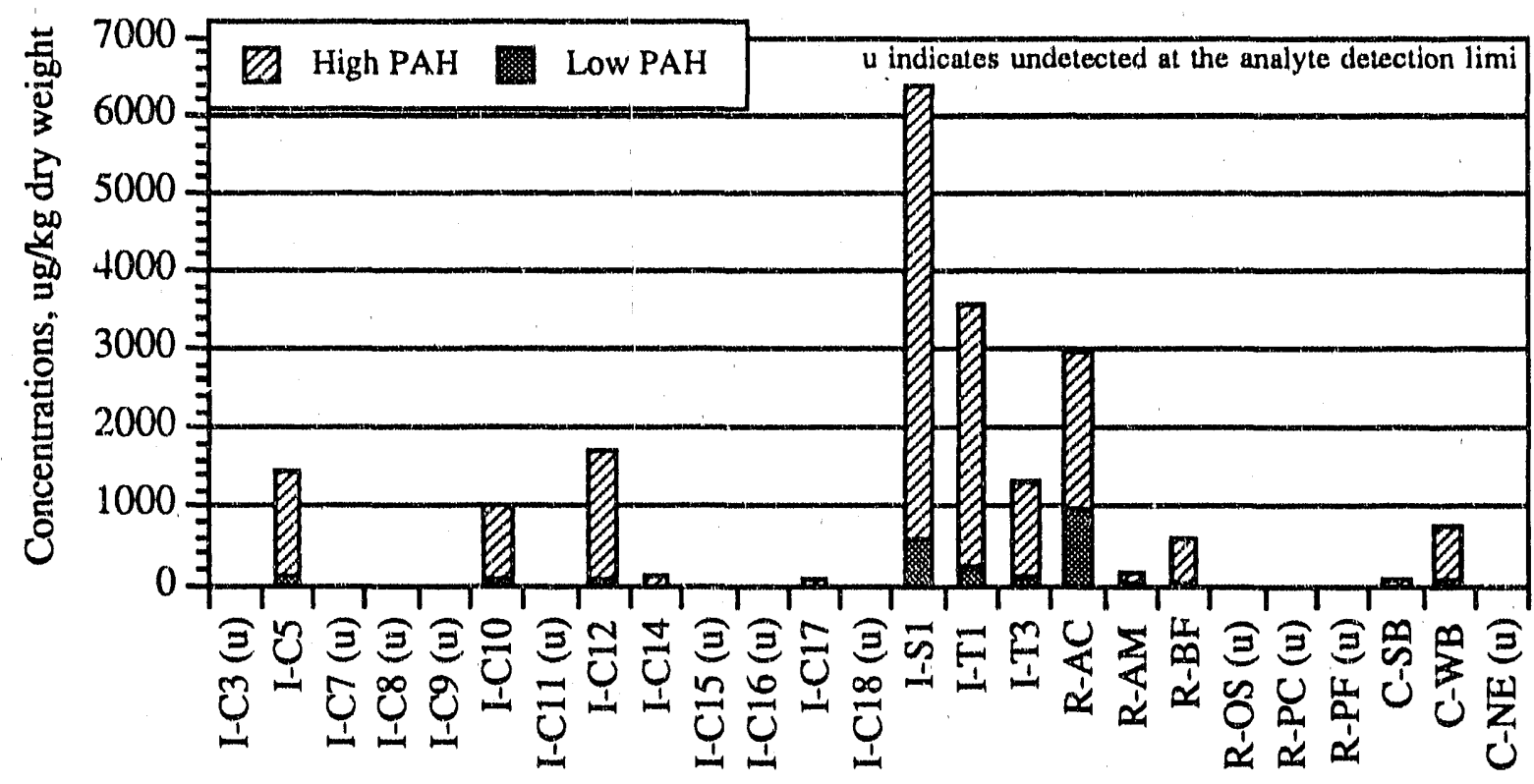

Sediment Treatment

EIGURE 3.51. Concentrations of LPAH and HPAH Found in Oakland Phase III A Retest Sediment Treatments

Figure 3.54 (tributyltin). Data for butyltin analyses are in Volume 2, Appendix D, Table D.14. Monobutlytin concentrations ranged from undetected to $5.8 \mu \mathrm{g} / \mathrm{kg}$; dibutylin concentrations ranged from undetected to $27.4 \mu \mathrm{g} / \mathrm{kg}$; and, tributytin concentrations ranged from undetected to 64.3 $\mu \mathrm{g} / \mathrm{kg}$. Table 3.11 summarizes the three sediment samples (I-C9, I-T1, and I-T3) with the highest butlytin concentrations.

\subsection{TOXICOLOGICAL TESTING RESULTS}

Six types of solid-phase toxicity tests were conducted to evaluate the 27 Oakland Harbor Phase III A sediment treatments. These toxicity tests were separate 10 and 28-day flow-thro.dgh evaluations of the polychaete $N$. caecoides and the clam M. nasuta (tested together), a 10-day flow-

TABLE 3.10. Total of PAH Concentrations for the Three Highest Sediment Treatments

Treatment

I-S1

I-T1

$\mathrm{R}-\mathrm{AC}$
LPAH \%

9.5

7.3

32.8
HPAH\%

90.5

92.7

67.2

\section{TotalPAH $(\mu \mathrm{g} / \mathrm{kg})$}

6379.98

3552.41

2983.90 


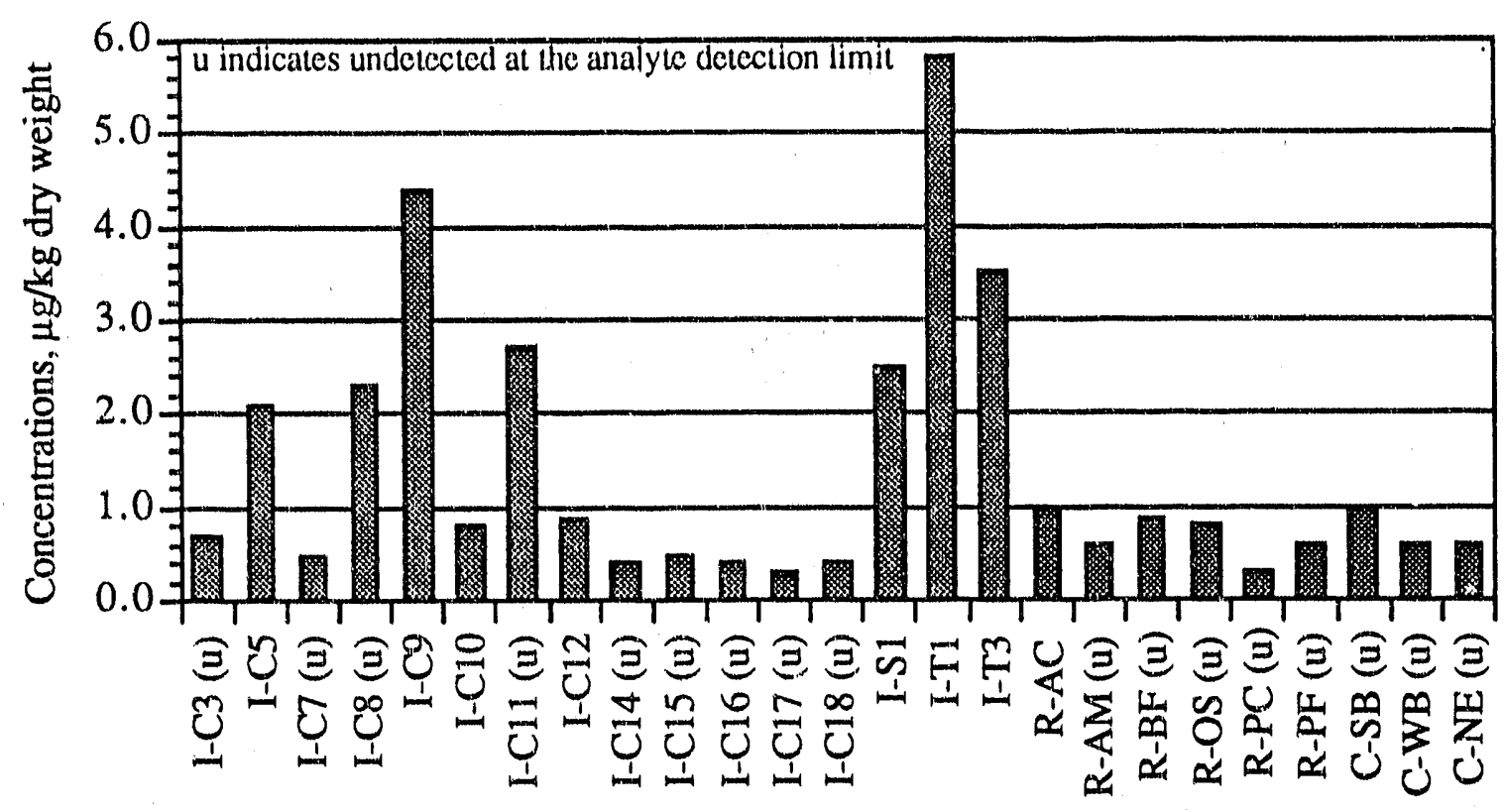

Sediment Treatment

FIGURE 3.52. Concentrations of Monobutyltin Found in Oakland Phase III A Retest Sediment Treatments

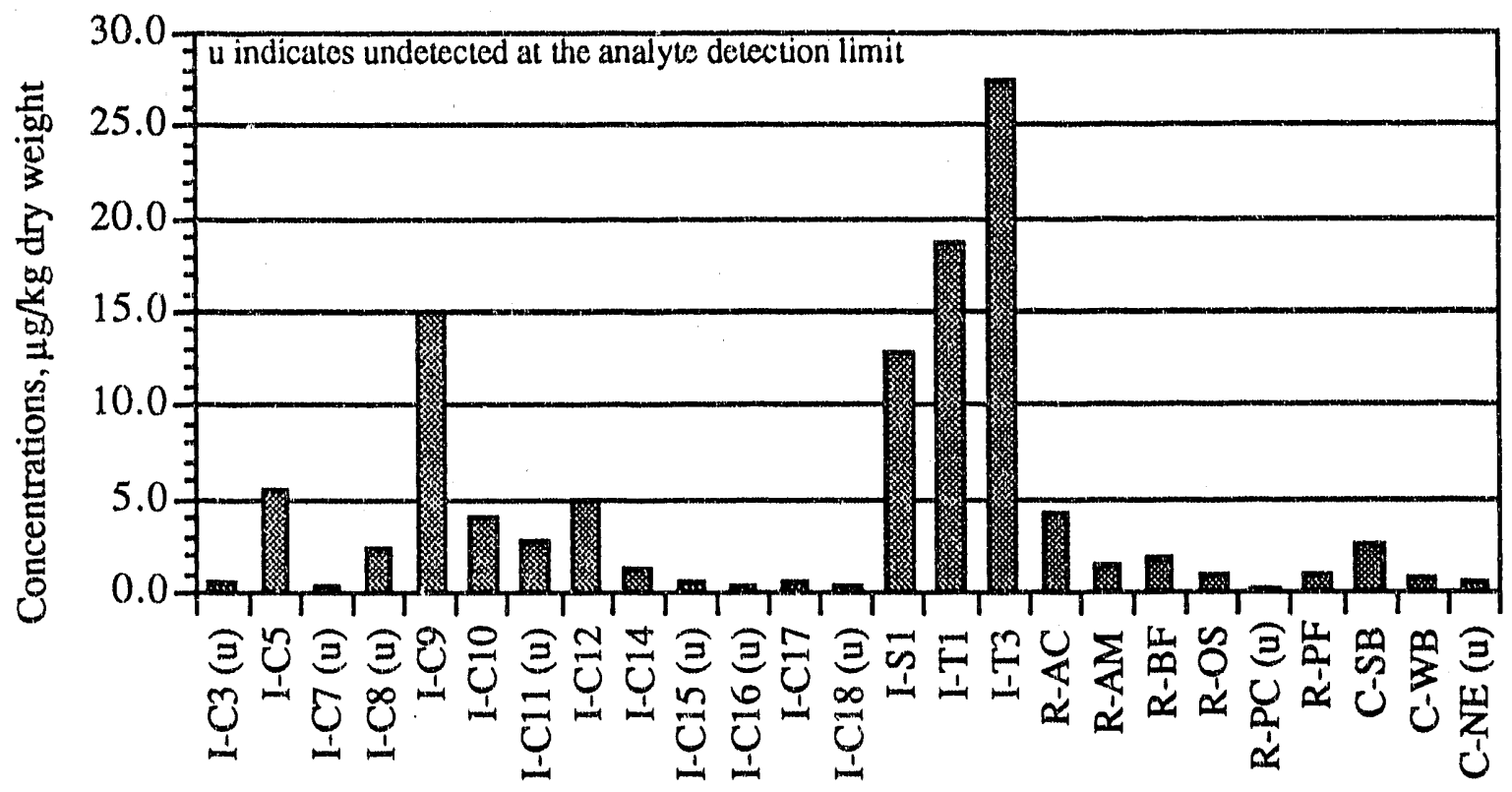

Sediment Treatment

FIGURE 3.53. Concentrations of Dibutyltin Found in Oakland Phase III A Retest Sediment Treatments 


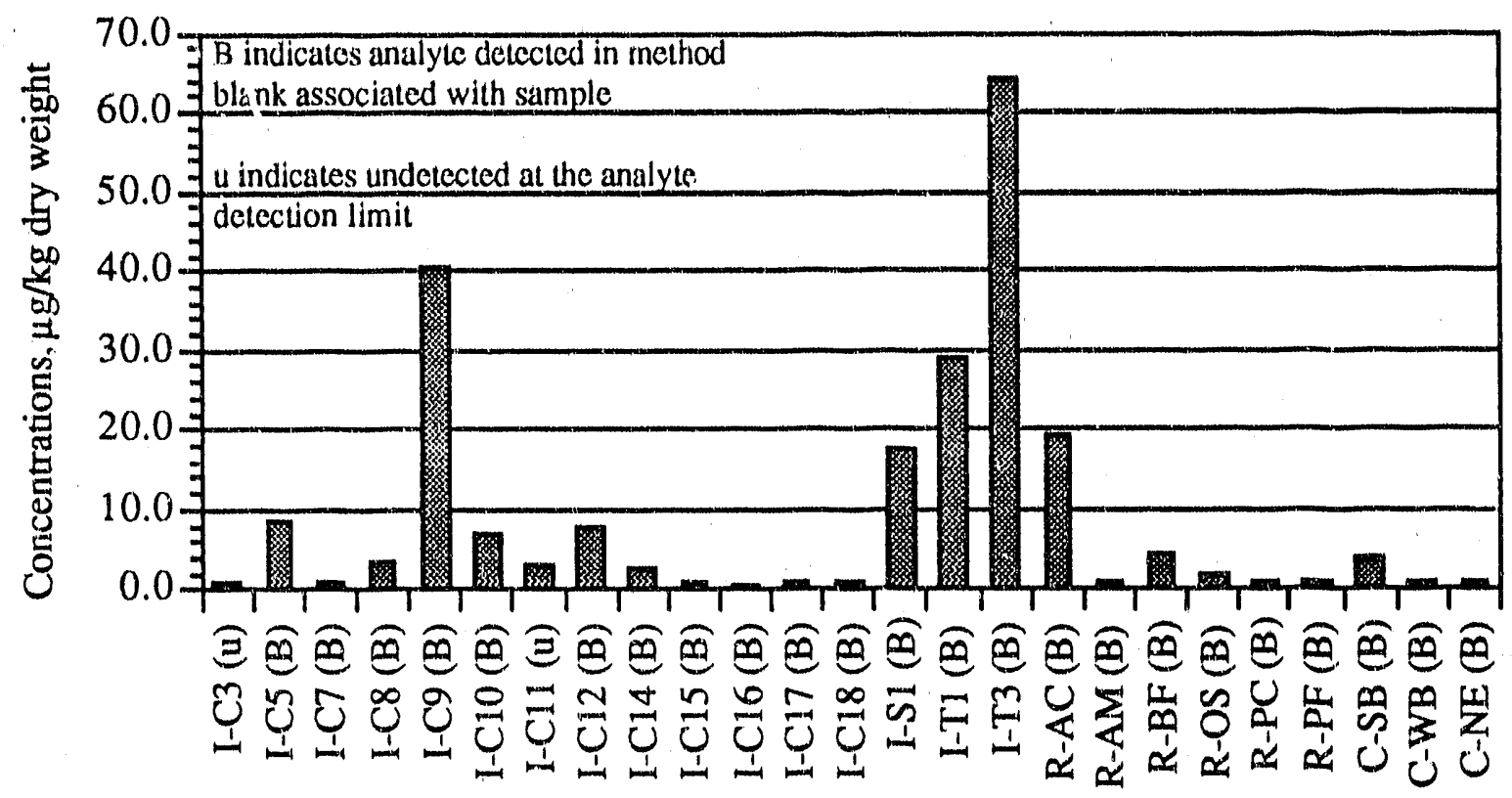

Sediment Treatmerit

FIGURE 3.54. Concentrations of Tributyltin Found in Oakland Phase III A Retest Sediment Treatments

through exposure using juvenile ( $<2$-in.-long) speckled sanddab $C$. stigmaeus, and three separate tests with the amphipod $R$, abronius under flow-through and static testing regimes.

The data resulting from each test were first evaluated to ensure that they met QA/QC guidelines, which included survival in noncontaminated (native control) sediments under acceptable water quality conditions during testing. After QA/QC review, the data were evaluated by ANOVA, followed by application of Tukey's HSD. These evaluations were used to compare the degree of increase in mortality relative to the reference site mortality. For these sets of data, an arcsine square-root transformation was applied to the proportion surviving to ensure homogeneity

TABLE 3.11. Concentrations of Butyltins in Three Oakland Phase III A Retest Sediment Treatments

Sediment

Treatment

I-C9

I-T1

I-T3

Monobutytin

4.4

5.8

3.5
Concentration $(4 \mathrm{~g} / \mathrm{kg})$ Dibutylin

15.0

18.6

27.4
Iributyltin

40.4

29.2

64.3 
of variances. These statistical analyses enabled us to determine whether the dredged material sediment treatments were significantly more toxic at $\alpha=0.10$, and showed at least $10 \%$ to $20 \%$ greater mortality than the appropriate reference sample. The increase in mortality relative to reference conditions was $10 \%$ for $N$. caecoides, $M$. nasuta, and C. stigmaeus 10 -day tests; $20 \%$ for $R$. abronius 10 -day test; and $20^{\circ}$, for the $N$. caecoides and $M$. nasuta 28 -day tests. Thus, when appropriate, the discussion of toxicity will include comparisons to all of the reference sediments: Alcatraz environs (R-AC), Alcatraz dredged material disposal site (R-AM), Bay Farm Island borrow area (R-BF), Point Reyes fine-grained sediment (R-PF), Point Reyes coarsegrained sediment (R-PC), and offshore sediment (R-OS). Because of the limited amount $c^{c}$ material available, reference R-OS was not tested in the 10-day $M$. nasuta $/ N$. caecoides exposure, the $C$. stigmaeus exposure, or the $R$. abronius exposure during this sampling/analytical phase of the Oakland Harboi testing program.

\subsubsection{0-Day Solid-Phase Flow-Through Test with $M$, nasuta and $N$, caecoides:}

The results of the $M$. nasuta and $N$. caecoides 10-day toxicological test are presented in Tables 3.12 through 3.14. A summary of the toxicological testing results is provided in Volume 2, Appendix E. Examination of the water quality data presented in Appendix E (Table E.5) shows that most measured parameters remained within target ranges during the test, although $\mathrm{pH}$, salinity, and flow rate were out of acceptable ranges on some test days for a few test containers. These fluctuations did not appear to affect observed mortality or influence test validity.

The results of the $M$. nasuta test are presented in Tabic 3.12, and show that $M$. nasuta exhibited relatively high survival in all sediment treatments, with mean survival ranging from $88 \%$ to $100 \%$. Survival of $M$. nasuta in its native control, C-SB, was $100 \%$, validating the test. The ANOVA identified significant differences between sediment treatments (Table 3.13), and Tukey's HSD produced the station groupings presented in Table 3.12. Table 3.12 also shows that with one exception, none of the test treatments from Oakland Inner Harbor were significantly different from the reference treatments R-AC, R-AM, R-BF, R-PF, and R-PC. The exception to this is sediment treatment I-C8, which was significantly different from R-AM, R-BF, R-PF, and R-PC. Survival in treatment $\mathrm{I}-\mathrm{C} 8$ was significantly different, as well as sufficiently low enough to show a greater than $10 \%$ decrease in survival from R-AM, R-PC, and R-PF.

The results of the $N$. caecoides test are presented in Table 3.14. This talole shows that $N$. caecoides survival ranged from $52.5 \%$ to $99 \%$, with survival below $80 \%$ observed in 9 of 27 treatments. The survival of $N$. caecoides in its native sediment control (C-NE) was $86 \%$, which is below the target limit of $90 \%$ specified in the QA Plan. For this reason, we qualified these data, 
TABLE 3.12. Results of 10-Day Solid-Phase Flow-Through Test With $M$. nasuta

\section{Sediment \\ Treatment}

I-C8

R-AC

I-S 1

I-C4

I-C11

I-C14

I-C 9

R-BF

R-PF

R-PC

I-C10

I-C15

I-C7

R-AM

I-C18

I-C5

I-T1

I-T3

I-T5

AC- 3

I-C17

AC- 1

I-C12

I-C16

C-SB

C.WB

C-NE

\begin{tabular}{c}
$\begin{array}{c}\text { Mean Percent } \\
\text { Survival }\end{array}$ \\
\hline
\end{tabular}

88.0

95.2

96.0

96.8

96.8

96.0

97.0

97.6

98.4

98.4

99.2

99.2

99.2

99.2

99.2

99.2

99.2

99.2

100.0

100.0

100.0

100.0

100.0

100.0

100.0

100.0

99.2
Statistical
Grouping

A

$\mathrm{AB}$

$A B$

$\mathrm{AB}$

$\mathrm{AB}$

$\mathrm{AB}$

$A B$

B

B

B

B

B

B

B

B

B

B

B

B

B

B

B

B

$N A^{(a)}$

NA

NA

(a) Control treatments not included in statistical analysis.

TABLE 3.13. ANOVA Results for the 10-Day Solid-Phase Flow-Through Test With M. nasuta

Source of

Variation.

Between Groups

Within Groups
Sum of

Squares

0.751

0.934
Mean
d.f.

23

95

0.033

0.010

F-Ratio

Significance

3.321

Level

0.0001 
TABLE 3.14. Results of 10-Day Solid-Phase Flow-Through Test With N. caecoides

\begin{tabular}{lc} 
Sediment & $\begin{array}{c}\text { Mean Percent } \\
\text { Sreatment }\end{array}$ \\
\cline { 2 - 2 } Survival \\
R-AM & 52.5 \\
I-C18 & 54.6 \\
I-C8 & 64.8 \\
I-C4 & 66.0 \\
I-S1 & 68.0 \\
I-C5 & 69.0 \\
I-T1 & 70.0 \\
I-T5 & 70.0 \\
I-T3 & 72.0 \\
I-C17 & 81.8 \\
I-C16 & 82.8 \\
AC-1 & 83.4 \\
R-BF & 86.8 \\
AC-3 & 87.2 \\
I-C14 & 87.4 \\
I-C9 & 86.6 \\
I-C15 & 90.6 \\
I-C10 & 92.2 \\
I-C7 & 91.4 \\
R-AC & 90.0 \\
I-C11 & 92.6 \\
R-PC & 94.0 \\
I-C12 & 96.6 \\
R-PF & 99.0 \\
C-SB & 94.0 \\
C-WB & 96.7 \\
C-NE & 86.0
\end{tabular}

and interpretation of these results are suspect, given the lower than acceptable survival of $N$. caecoides in its native control sediment. The 10- and 28-day $M$. nasuta and $N$. caecoides tests were rerun at a later date. The results of both the initial test and retest are presented in this report.

\subsubsection{8-Day Solid-Phase Flow-Through Test with $M$. nasuta and $N$. caecoides}

The results of the $M$. nasuta and $N$. caecoides 28-day toxicological tests are presented in Table 3.15. A summary of the toxicological testing results is provided in Volume 2, Appendix $F$. Examination of water quality data presented in Appendix F (Table F.5) shows that almost all of the measured parameters remained within range during the test, although in some containers, $\mathrm{pH}$ measurements were below target limits and flow rates exceeded specified limits. Test duration was 31 days for treatments I-S1, R-AC, R-OS, R-PC, R-PF, and C-NE because of an error in test duration estimation. These deviations did not appear to affect test organsim survival or test validity. 
TABLE 3.15. Results of 28-Day Solid-Phase Flow-Through Test With M. nasuta and $N$. caecoides

\section{Sediment \\ Treatment}

AC-1

AC-3

I-C4

I-C5

I-C7

I-C8

I-C9

I. C10

I-C11

I-C12

I-C14

I-C 15

I-C16

I-C17

I-C18

I-S 1

I-T1

I-T3

I-T5

R-AC

R-AM

R-BF

$\mathrm{R}-\mathrm{OS}$

R-PC

R-PF

C-SB

C-WB

C-NE
Mean Percent

Survival of $M$ nasuta

95.0

96.0

94.4

99.2

99.2

86.4

90.4

91.2

96.8

98.4

96.0

93.6

95.2

84.8

95.2

92.8

96.0

94.4

96.8

94.4

98.4

32.6

89.6

98.4

98.4

89.6

90.0

96.0
Mean Percent

Survival of $N$ caecoides (a)

82.0

86.0

74.6

46.6

92.0

68.6

79.0

86.0

92.0

97.2

85.4

86.8

72.6

79.2

65.4

73.8

67.2

71.4

68.8

73.4

64.0

84.0

96.7

97.5

89.5

88.0

81.3

58.7

(a) N. caecoides tissues were not analyzed for tissue chemistry.

The mean percent survival of $M$. nasuta (Table 3.15) shows that survival was generally over $90 \%$, with the exception of treatments I-C8, I-C17, R-OS, and C-SB. The lowest survival was observed in $1-\mathrm{C} 17$, at $84.8 \%$. Survival of $M$. nasuta in its native sediment, C-SB, was $89.6 \%$, which validates the test, because $80 \%$ survival is required for the 28 -day exposure.

The mean percent survival of $N$. caecoides (Table 3.15) shows that survival of $N$. caecoides ranged from $46.6 \%$ to $97.5 \%$. The $58.7 \%$ survival of $N$. caecoides in its native sediment, C-NE, did not meet the requirement of $80 \%$; thus, the test is not valid. As a result, the organisms were not prepared for bioaccumulation. 


\subsubsection{0-Day Solid-Phase Flow-Through Retest with $M$. nasute and $N$. caecoides}

Because of the low survival of $N$. caecoides in its native sediment control during the 10and 28-day exposures, it was decided to rerun both the 10- and 28-day exposures. Test, reference, and control sediments were collected in September 1990 and the tests were rerun during that time. The results of the 10-day solid-phase flow-through $M$. nasuta/ $N$. caecoides retest are presented in Tables 3.16 to 3.19. A summary of toxicological results may be found in Volume 2, Appendix G. Examination of the water quality data presented in Appendix G (Table G.5) shows that all measured parameters remained within range during the test except for a few occurrences of low $\mathrm{pH}$ measurements and flow-rate fluctuations. These fluctuations did not appear to affect test organism survival or data validity.

The results of the 10-day $M$. nasuta retest, presented in Table 3.16, show high survival in all treatments. The $100 \%$ survival of $M$. nasuta in its native sediment, C-SB, validates the test. The ANOVA information, presented in Table 3.17, shows that none of the treatments were statistically different from each other based on percent survival. Sediment treatment I-C8, which, during the initial test, had significantly lower survival (88\%), had $100 \%$ survival in the retest.

The results of the 10-day $N$. caecoides retest are presented in Tables 3.18 and 3.19. This test was set up over a period of days oecause of its size. Sequential shipments of $N$. caecoides arrived daily, were equilibrated to laboratory conditions, and then tested. The $N$. caecoides control (C-NE) was initiated at the end of the first day. It was noted that the worms used in this control included individuals that appeared to be less active, and not representative of the test organisms used earlier in the day for the test sediment treatments. It was decided to set up a serond control treatment, C-NE-A, later in the initiation process to evaluate our observations on the apparent difference in the test organisms' general health. Survival of $N$. caecoides during this test ranged from $31 \%$ to $98 \%$ (Table 3.18 ). Control survival was $85 \%$ in C-NE (the original control), and $98 \%$ in the control C-NE-A, which was set up later in the experiment. The $85 \%$ survival observed in C-NE led us to believe that our observations and suppositions regarding the health of some of the test organisrns used in the first control treatment were correct; the high survival recorded in C-NE-A validates the test. The ANOVA of the data show that significant differences do exist between sediment treatments. Only reference treatment R.PC was significantly different from R-AC. Comparison of the survival of $N$. caecoides in test sediments relative to the reference R-PC produced the greatest number (eight) of significantly lower survival: I-C16, I-C18, I-C17, I-C15, I-T3, I-C14, I-T1, and I-C11. Survival at each of these locations was not only statistically significant, but was at least $10 \%$ less than at R-PC. Comparison of $N$. caecoides in test sediments 
TABLE3.16. Results of 10-Day Solid-Phase Flow-Through Retest With M. nasuta

Sediment
Treatment

I-C10

R-AC

I-C5

R-PF

R-PC

I-T1

I-C15

I-C18

I-C11

R-OS

I-T3

I-C17

I-C12

I-S 1

I-C7

I-C16

I-C3

R-AM

R-BF

I-C 14

I-C9

I-C8

C-SB

C-NE

C-NE-A

\begin{tabular}{c}
$\begin{array}{c}\text { Mean Percent } \\
\text { Survival }\end{array}$ \\
\hline
\end{tabular}

98.0

97.0

99.0

99.0

99.0

99.0

99.0

99.0

99.0

99.0

99.0

100.0

100.0

100.0

100.0

100.0

100.0

100.0

100.0

100.0

100.0

100.0

100.0

98.0

99.0
Statistical

Grouping

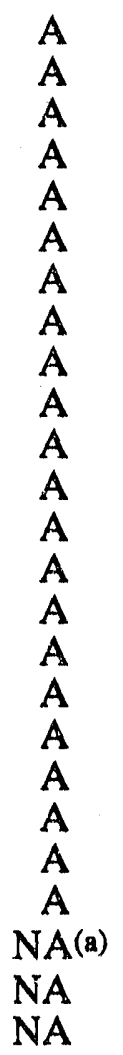

(a) Control treatments not included in statistical analysis.

TABLE 3.17. ANOVA Fesults for the 10-Day Solid-Phase Flow-Through Retest With $M$. nasuta

Source of

Variation.

Between Groups

Within Groups
Sum of

Squares

0.089

0.556 $\begin{array}{cc}\text { Mean } \\ \text { d.f. } & \text { Square }\end{array}$

21

88
F-Ratio

0.670

0.004

0.006
Significance Level

0.8510 
TABLE 3.18. Results of 10-Day Solid-Phase Flow-Through Retest With $N$. caecoides

Sediment
Treatment

I-C16

I-C18

I-C17

I-C15

I-T3

I-C14

I-T1

I-C11

$\mathrm{R}-\mathrm{AC}$

I-C10

I-S1

I-C8

R-OS

I-C12

I-C5

I-C9

R-PF

R-BF

I-C7

I-C3

R-AM

R-PC

C-SB

C-NE

C-NE-A
Mean Percent

Survival

31.0

39.0

45.0

46.0

57.0

64.0

69.0

70.0

71.0

71.0

73.0

74.0

76.6

73.0

79.0

80.0

80.0

80.0

87.0

90.0

92.0

91.6

84.0

85.0

98.0
Statistical

Grouping

A

$\mathrm{AB}$

$A B C$

$A B C$

$A B C D$

BCDE

CDE

CDEF

CDEF

CDEFG

CDEFG

CDEFG

DEFG

DEFG

DEFG

DEFG

DEFG

DEFG

EFG

FG

$\mathrm{FG}$

$N_{A}^{(a)}$

NA

NA

(a) Control treatments not included in statistical analysis.

TABLE 3.19. ANOVA Results for the 10-Day Solid-Phase Flow-Through Retest With $N$. caecoides

Source of

Variation.

Between Groups

Within Groups
Sum of

Squares

4.141

1.538
Mean

d.f. Square

21

88

0.197

0.017

F-Ratio

Significance

Level

0.0001 
relative to the reference $\mathrm{R}-\mathrm{AM}$ produced seven sediment treatments that had significantly lower survival: I-T1, I-C14, I-T3, I-C15, I-C17, I-C18, and I-C16. Treatments I-C15, I-C16, I-C17, and $\mathrm{l}-\mathrm{C} 18$ produced significantly lower survivals relative to the references $\mathrm{R}-\mathrm{BF}, \mathrm{R}-\mathrm{OS}$, and R-PF. Survival in these test treatments was at least $10 \%$ lower than reference survival. Finally, comparison of test treatment survival to the survival recorded in the reference $\mathrm{R}-\mathrm{AC}$ produced two treatments that were statistically different because of lower survival: I-C16 and I-C18. These were also at least $10 \%$ lower than the reference R-AC. During this test, I-C16 and I-C18 had statistically lower survival than all six references.

\subsubsection{8-Day Solid-Phase Flow-Through Retest with $M$ nasuta and $N$, caecoides}

The results of the 28-day $M$. nasuta and $N$. caecoides retests are presented in Table 3.20. A summary of toxicological results is presented in Volume 2, Appendix H. Examination of the water quality data presented in Appendix H (Table H.5) shows that all ineasured parameters remained within range during the test, with the exception of flow rate in some containers and isolated occurrences of low $\mathrm{pH}$. These variations occurred periodically and did not appear to influence test organism survival or test validity.

The mean percent survival of $M$. nasuta (Table 3.20) was high, ranging from $94.4 \%$ to $100 \%$. The $M$. nasuta in this retest were not used for bioaccumulation testing but were added to be consistent with established testing procedures.

Mean percent survival of $N$. caecoides ranged from $30.8 \%$ in treatment I-C16 to $96.2 \%$ in R-AM and R-PF. The survival recorded in the two control sediments was $81.3 \%$ for C-NE and $96.0 \%$ for C-NE-A. Both of these control survivals were above the $80 \%$ requirement; thus, the test was validated and the tissues were prepared for bioaccumulation.

\subsubsection{0-Day Solid-Phase Flow-Through Test with $C_{\text {custigmaeus }}$}

The results of the 10-day flow-through $C$. stigmaeus test are presented in Tables 3.21 and 3.22. A summary of the toxicological testing results is presented in Volume 2, Appendix I. Examination of the water quality data presented in Appendix I (Table I.3) shows that all measured parameters remained within range during the test, with the exception of flow rate, which was out of range in a few test containers. These events were isolated and did not appear to influence test organism survival. The results of the $C$. stigmaeus test presented in Table 3.21 shows that survival ranged from $70.0 \%$ to $100 \%$. Survival in control sedirnent (C-NE) was $95.0 \%$, validating the test. The ANOVA of these data, presented in Table 3.22, shows no significant differences between sediment treatments. 
TABLE 3.20. Results of the 28-Day Solid-Phase Flow-Through Retest With $M$. nasuta and $N$. caecoides

\section{Sediment \\ Treatment}

I-C3

I-C5

I-C7

I-C8

I-C?

I-C10

I-C11

I-C12

I-C14

I-C15

I-C16

I-C17

I-C18

I-S 1

I-T1

I-T3

R-AC

R-AM

$\mathrm{R}-\mathrm{BF}$

R-OS

R-PC

R-PF

C-SB

C-NE

C-NE-A
Mean Percent Survival of $M$. nasuta

99.0

96.0

100.0

99.0

96.8

100.0

98.4

99.0

96.0

94.4

98.4

96.8

96.8

96.8

96.0

96.8

94.4

99.2

96.0

96.0

94.4

97.6

94.4

96.8

97.6
Mean Percent Survival of $N$. caecoides

91.2

86.2

88.4

74.6

78.0

84.6

73.2

80.6

83.4

44.6

30.8

56.6

38.6

82.0

78.0

75.4

90.0

96.2

85.4

92.6

92.2

96.2

94.0

81.3

96.0

\subsubsection{0-Day Solid-Phase Flow-Through Test with $R$ abronius (with Aeration)}

The results of the 10-day flow-through $R$. abronius test are presented in Tables 3.23 and 3.24. Associated data related to the toxicological test are found in Volume 2, Appendix J.

Examination of the water quality data presented in Appendix J (Table J.3) shows that all measured parameters remained within range during the test except a few isolated occurrences of low $\mathrm{pH}$, high salinity, and deviations of flow beyond target ranges. Neither water quality nor test duration appeared to affect test organism survival or test data validity.

The results of the test show a wide range of toxicological response, with survivals ranging from $19 \%$ to $99 \%$ (Table 3.23). The $96 \%$ survival recorded in the amphipod native control (C-WB) validates the test. The ANOVA of these data is presented in Table 3.24 and shows that 
TABLE 3.21. Results of the 10-Day Solid-Phase Flow-Through Test With C. stigmaeus

\begin{tabular}{lcc}
$\begin{array}{l}\text { Sediment } \\
\text { Treatment }\end{array}$ & $\begin{array}{c}\text { Mean Percent } \\
\text { Survival }\end{array}$ & $\begin{array}{c}\text { Statistical } \\
\text { Groupi }\end{array}$ \\
\cline { 2 - 3 } R-PF & 70.0 & $\mathrm{~A}$ \\
I-T3 & 83.3 & $\mathrm{~A}$ \\
R-AM & 85.0 & $\mathrm{~A}$ \\
R-PC & 85.0 & $\mathrm{~A}$ \\
I-C8 & 85.0 & $\mathrm{~A}$ \\
AC-1 & 86.0 & $\mathrm{~A}$ \\
I-C18 & 86.0 & $\mathrm{~A}$ \\
I-C4 & 90.0 & $\mathrm{~A}$ \\
I-C16 & 90.0 & $\mathrm{~A}$ \\
AC-3 & 88.0 & $\mathrm{~A}$ \\
I-S1 & 90.0 & $\mathrm{~A}$ \\
I-C10 & 90.0 & $\mathrm{~A}$ \\
R-AC & 90.0 & $\mathrm{~A}$ \\
I-T5 & 93.3 & $\mathrm{~A}$ \\
I-C11 & 90.0 & $\mathrm{~A}$ \\
I-C17 & 94.2 & $\mathrm{~A}$ \\
I-C9 & 92.0 & $\mathrm{~A}$ \\
I-C15 & 92.0 & $\mathrm{~A}$ \\
I-C7 & 92.0 & $\mathrm{~A}$ \\
I-T1 & 95.0 & $\mathrm{~A}$ \\
R-BF & 98.0 & $\mathrm{~A}$ \\
I-C14 & 100.0 & $\mathrm{~A}$ \\
I-C12 & 100.0 & $\mathrm{~A}$ \\
I-C5 & 100.0 & $\mathrm{~A}$ \\
C-SB & 86.0 & NA(a) \\
C-WB & 92.0 & $\mathrm{NA}$ \\
C-NE & 95.0 & NA \\
& &
\end{tabular}

(a) Control treatments not included in statistical analysis.

TABLE 3.22. ANOVA Results for the 10-Day Solid-Phase Flow-Through Test With C. stigmaeus

Source of

Variation

Between Groups

Within Groups
Sum of

Squares

1.530

2.699

\begin{tabular}{|c|c|c|}
\hline d.f. & $\begin{array}{l}\text { Mean } \\
\text { Square }\end{array}$ & F-Ratio \\
\hline & $\begin{array}{l}0.067 \\
0.041\end{array}$ & 1.626 \\
\hline
\end{tabular}

Significance

Level

0.0645 
TABLE 3223. Results of the 10-Day Solid-Phase Flow-Through Test With $R$. abronius (with Aeration)

\begin{tabular}{|c|c|c|}
\hline $\begin{array}{l}\text { Sediment } \\
\text { Treatment }\end{array}$ & $\begin{array}{c}\text { Mean Percent } \\
\text { Survival }\end{array}$ & $\begin{array}{l}\text { Statistical } \\
\text { Grouping }\end{array}$ \\
\hline I-C8 & 19.0 & A \\
\hline $\mathrm{I}-\mathrm{Cl}$ & 47.0 & $\mathrm{AB}$ \\
\hline R-PF & 48.0 & $\mathrm{AB}$ \\
\hline R-BF & 48.0 & $\mathrm{AB}$ \\
\hline R-AC & 52.0 & $\mathrm{ABC}$ \\
\hline I-C10 & 53.0 & $\mathrm{ABC}$ \\
\hline R-OS & 55.0 & $\mathrm{ABC}$ \\
\hline I-C7 & 58.0 & BC \\
\hline I-C9 & 64.0 & $B C D$ \\
\hline AC-3 & 66.0 & $B C D$ \\
\hline I-S1 & 69.0 & $\mathrm{BCD}$ \\
\hline I-C11 & 71.0 & $\mathrm{BCD}$ \\
\hline $\mathrm{I}-\mathrm{C} 12$ & 71.0 & $\mathrm{BCD}$ \\
\hline I-C5 & 72.0 & BCD \\
\hline $\mathrm{I}-\mathrm{C} 15$ & 74.0 & $\mathrm{BCD}$ \\
\hline I-C4 & 75.0 & $\mathrm{BCD}$ \\
\hline I-C14 & 73.0 & $B C D$ \\
\hline I-C16 & 80.0 & $B C D$ \\
\hline I-TS & 80.0 & $\mathrm{BCD}$ \\
\hline I-T3 & 81.0 & $\mathrm{BCDE}$ \\
\hline$A C-1$ & 81.0 & $\mathrm{BCDE}$ \\
\hline I-C18 & 84.0 & CDE \\
\hline $\mathrm{I}-\mathrm{T} 1$ & 90.0 & $\mathrm{DE}$ \\
\hline R-AM & 93.0 & $\mathrm{DE}$ \\
\hline R-PC & 99.0 & $E$ \\
\hline C-SB & 59.0 & $N A(a)$ \\
\hline C-WB & 96.0 & NA \\
\hline C-NE & 97.0 & NA \\
\hline
\end{tabular}

(a) Control treatments not included in statistical analysis.

TABLE 3.24. ANOVA Results for the 10-Day Solid-Phase Flow-Through Test With $R$, abronius (with Aeration)

\begin{tabular}{llcccc}
$\begin{array}{l}\text { Source of } \\
\text { Variation }\end{array}$ & $\begin{array}{l}\text { Sum of } \\
\text { Squares }\end{array}$ & d.f. & $\begin{array}{c}\text { Mean } \\
\text { Square }\end{array}$ & E-Ratio & $\begin{array}{c}\text { Significance } \\
\text { Level }\end{array}$ \\
\cline { 1 - 2 } Between Groups & 5.869 & 24 & 0.245 & 8.361 & 0.0001 \\
Within Groups & 2.896 & 99 & 0.029 & &
\end{tabular}


significant differences exist between sediment treatments. Comparison of the six reference sediment treatments and the three control sites shows that R-PF, R-BF, R-AC, R-OS, and C-SB have significantly lower survival than reference sediment treatments R-AM and R-PC and control sediment treatments C-WB and C-NE. Comparison of amphipod survival in test sediments relative to R-PC showed that 15 of 19 treatments had significt ntly lower survival than R-PC (Table 3.23). Comparison of amphipod survival in test sediments relative to R-AM showed that only 4 of 19 test treatments (I-C8, I-C17, I-C10, and I-C7) had significantly lower survival than R-AM; those stations also had a greater than $20 \%$ increase in mortality over R-AM.

\subsubsection{0-Day Solid-Phase Elow-Through Test with $R$ abronius (without Aeration)}

The results of the flow-through $R$. abronius test without aeration are presented in Tables 3.25 and 3.26. Data pertaining to this test are presented in Volume 2, Appendix $\mathrm{K}$. Examination of the water quality data presented in Appendix K (Table K.3) shows that all measured parameters remained within the target range during the test, except for isolated occurrences of low $\mathrm{pH}$ and higher flow rates than targeted. These deviations did not appear to affect test organism survival or test validity.

Percent mortality in this test ranged from $26 \%$ to $98 \%$ (Table 3.25 ), with the majority of sediment treatments exhibiting less than $80 \%$ survival. The $92 \%$ survival recorded in the native control, C-WB, validates the test. The ANOVA results for these data. presented in Table 3.26, show that there are statistical differences between sediment treatments. Comparison of amphipod survival in test treatments to R-PC showed that seven test treatments were statistically different from R-PC: I-C8, I-C17, I-C10, I-C11, AC-3, I-C14, and I-C9. Comparison of amphipod survival in test treatments to R-AM showed that, because of low survival, only I-C8 was statistically different. Three of these sediment treatments (I-C8, I-C17, and I-C10) also showed significantly lower survival in the flow-through system that was aerated.

\subsubsection{0-Day Solid-Phase Static Test with $R$ abronius (with Aeration)}

The results of the static $R$. abronius test with aeration are presented in Tables 3.27 and 3.28. Data pertaining to this test are presented in Volume 2, Appendix L. Exarnination of the water quality data presented in Appendix L (Table L.3) shows that all measured parameters remained within the targeted range during the test, except for a few isolated occurrences of low or high $\mathrm{pH}$. These data indicate no reason to suspect that water quality influenced test organism survival or test validity. 
TABLE 3.25. Results of the 10-Day Solid-Phase Flow-Through Test With $R$. abronius (without Aeration)

\begin{tabular}{lcc}
$\begin{array}{l}\text { Sediment } \\
\text { Ireatment }\end{array}$ & $\begin{array}{c}\text { Mean Percent } \\
\text { Survival }\end{array}$ & \multicolumn{1}{c}{$\begin{array}{c}\text { Statistical } \\
\text { Grouping }\end{array}$} \\
\cline { 2 - 3 } R-BF & & \\
I-C8 & 26.0 & $\mathrm{~A}$ \\
R-PF & 33.0 & $\mathrm{AB}$ \\
I-C17 & 41.0 & $\mathrm{ABC}$ \\
I-C10 & 57.0 & $\mathrm{ABCD}$ \\
I-C11 & 60.0 & $\mathrm{ABCD}$ \\
R-OS & 61.0 & $\mathrm{ABCD}$ \\
R-AC & 61.0 & $\mathrm{ABCD}$ \\
AC-3 & 61.0 & $\mathrm{ABCD}$ \\
I-C14 & 62.0 & $\mathrm{ABCD}$ \\
I-C9 & 59.0 & $\mathrm{ABCD}$ \\
I-S1 & 65.0 & $\mathrm{ABCD}$ \\
I-C7 & 70.0 & $\mathrm{ABCDE}$ \\
I-C15 & 70.0 & $\mathrm{ABCDE}$ \\
I-C4 & 72.0 & $\mathrm{BCDE}$ \\
AC-1 & 72.0 & $\mathrm{BCDE}$ \\
I-C5 & 76.0 & $\mathrm{BCDE}$ \\
I-T1 & 80.0 & $\mathrm{CDE}$ \\
I-C16 & 81.0 & $\mathrm{CDE}$ \\
I-C12 & 82.0 & $\mathrm{CDE}$ \\
I-T5 & 80.0 & $\mathrm{CDE}$ \\
I-T3 & 81.0 & $\mathrm{CDE}$ \\
I-C18 & 85.0 & $\mathrm{CDE}$ \\
R-AM & 86.3 & $\mathrm{DE}$ \\
R-PC & 93.0 & $\mathrm{DE}$ \\
C-SB & 98.0 & $\mathrm{E}$ \\
C-WB & 77.0 & $\mathrm{NA}(\mathrm{a})$ \\
C-NE & 92.0 & $\mathrm{NA}$ \\
S-N & 95.0 &
\end{tabular}

(a) Control treatments not included in statistical analysis.

TABLE 3.26. ANOVA Results for the 10-Day Solid-Phase Flow-Through Test With $R$. abronius (without Aeration)

Source of

Variation

Between Groups

Within Groups
Sum of

Squares

5.321

4.170

\section{d.f. \\ 24}

98
Mean

Square Furatio

0.222

0.043
Significance Level

0.0001 
TABLE 3.27. Results of the 10-Day Solid-Phase Static Test With $R$. abronius (with Aeration)

\begin{tabular}{lcc}
$\begin{array}{l}\text { Sediment } \\
\text { Treatment }\end{array}$ & $\begin{array}{c}\text { Mean Percent } \\
\text { Survival }\end{array}$ & \multicolumn{1}{c}{$\begin{array}{c}\text { Statistical } \\
\text { Grouping }\end{array}$} \\
\cline { 2 - 3 } I-C17 & 49.0 & A \\
I-C9 & 50.0 & AB \\
R-BF & 51.0 & AB \\
R-OS & 63.0 & ABC \\
I-C8 & 65.0 & ABCD \\
R-PF & 70.0 & ABCDE \\
I-S1 & 71.0 & ABCDE \\
I-C7 & 77.0 & ABCDEF \\
I-C16 & 76.2 & ABCDEF \\
I-C14 & 79.0 & ABCDEF \\
I-C12 & 82.0 & ABCDEF \\
I-C4 & 84.0 & BCDEF \\
R-AC & 86.0 & CDEF \\
AC-3 & 84.0 & CDEF \\
I-C15 & 86.0 & CDEF \\
I-T1 & 89.0 & CDEF \\
I-T3 & 87.0 & CDEF \\
I-T5 & 88.0 & CDEF \\
I-C10 & 91.0 & CDEF \\
I-C18 & 91.0 & CDEF \\
AC-1 & 91.0 & CDEF \\
I-C11 & 92.0 & DEF \\
R-AM & 93.0 & EF \\
R-PC & 95.0 & EF \\
I-C5 & 94.0 & F \\
C-SB & 90.0 & NA(a) \\
C-WB & 98.0 & NA \\
C-NE & 93.1 &
\end{tabular}

(a) Control treatments not included in statistical analysis.

TABLE 3.28. ANOVA Results for the 10-Day Solid-Phase Static Test With $R$. abronius (with Aeration)

Source of

Variation

Between Groups

Within Groups
Sum of

Squares

4.190

2.803 $\begin{array}{ll} & \text { Mean } \\ \text { d.f. } & \text { Square }\end{array}$

24

99

0.175

0.028

E-Ratio

Significance Level

6.166

0.0001 
Table 3.27 presents the results of the 10-day static test, in which survival ranged from $49 \%$ to $98 \%$. The $98 \%$ survival recorded in the amphipod native control sediment (C-WB) validates the test. Survival of $70 \%$ or less occurred in sediment treatments I-C17, I-C9, R-BF, R-OS, I-C8, and R-PF. Survival of $90 \%$ or above occurred in sediment treatments $\mathrm{I}-\mathrm{C} 10, \mathrm{I}-\mathrm{Cl} 18, \mathrm{AC}-1$, I-C11, C-NE, R-AM, R-PC, I-C5, C-SB, and C-WB. The ANOVA of these data (Table 3.28) showed that there were significant differences between treatments.

Comparison of reference sediment treatments show that R-BF, R-OS, and R-PF have significantly lower survival than R-PC, R-AM, and R-AC. Comparison of test sediment treatment resronse to references shows that $\mathrm{I}-\mathrm{C} 8, \mathrm{I}-\mathrm{C}$, and $\mathrm{I}-\mathrm{C} 17$ are statistically different from $\mathrm{R}-\mathrm{PC}$ and $\mathrm{R}-\mathrm{AM}$, and that $\mathrm{I}-\mathrm{C} 9$ and $\mathrm{I}-\mathrm{C} 17$ are statistically different from R-AC. None of the sediment treatments have significantly lower survival than reference sediments from R-PF, R-OS, or R-BF. In each type of test, sediment treatments I-C17 and I-C8 significantly influenced amphipod survival.

\subsection{SUSPENDED-PARTICULATE-PHASE TESTS}

Suspended-particulate-phase toxicity tests were conducted on three species of sensitive marine organisms: the mysid shrimp $H$. sculpta, the speckled sanddab $C$. stigmaeus, and larvae of the pacific oyster C. gigas. These tests evaluated the toxicity of the SPP of treatments BC-3, BC-4, R-PC and C-SB. Composite BC-3 was composed of Oakland Inner Harbor stations I-C14, I-C15, I-C16, I-C17, and I-C18. Composite BC-4 was composed of Oakland Inner Harbor stations I-C9, I-C10, I-C11, and I-C12. Four concentrations were tested: 0\% (sea water), 10\%, $50 \%$, and $100 \%$ SPP. In addition, water from the Alcatraz disposal area was tested at $100 \%$ concentration. The SPP preparation is described in Section 2.3.3 and toxicological testing procedures are found in Section 2.6.

The data resuiting from each test were first evaluated to determine whether they met QAVQC requirements, which included control survival and appropriate water quality conditions during testing. The data for each treatment were then statistically evaluated with a two-sample t-test that compared the survival in control treatments against the 100\% SPP treatments. If the result was significant and a 50\% reduction in survival relative to control was noted, LC50 or EC50 estimates were made using a trimmed Spearman-Karber model.

\subsubsection{6-h Suspended-Particulate-Phase Static Test with H sculpte}

The results of the 96-h $H$. sculpta test are presented in Tables 3.29 and 3.30. A summary of the toxicological results for this test is provided in Volume 2, Appendix M. Examination of 
TABLE 3.29. Results of the H. sculpta Suspended-Particulate-Phase Test

Sediment
Treatment

BC-3

BC-3

BC-3

$\mathrm{BC}-3$

BC- 4

BC-4

BC-4

BC-4

R-PC

R-PC

R-PC

R-PC

C-SB

C-SB

C-SB

C-SB

Alcatraz Water (a)

Alcatraz Water (b)
\% SPP

Concentration

0

10

50

100

0

10

50

100

0

10

50

100

0

10

50

100

100

100
Mean

Porcent

Survival

96.7

90.0

86.7

83.3

93.3

96.7

73.3

76.7

96.7

93.3

70.0

53.3

96.7

93.3

76.7

80.0

80.0

80.0

(a) First Run

(b) Second Run

TABLE 3,30. T-Test and LC50 Determinations for H. sculpta Suspended-Particilate-Phase Test

Sediment

Table

Calculated

Treatment

t-value

t-value

Significance(a) $^{(a)}$

LC50 as

BC-3

2.776

d.f.

1.3416

2.776

3.5355

R-PC

2.776

9.1924

C-SB

2.776

2.5000

NS(b)
$S(d)$
$S$
$N S$

$>100$ (c)

$>100$

$>100$

$>100$

(a) At $\alpha=0.05$ for two sample t-test comparisons of $0 \%$ and $100 \%$ SPP.

(b) Not significant.

(c) Test organism survival was $>50 \%$ in all concentrations.

(d) Significant. 
the water quality data presented in Volume 2, Appendix M (Table M.3) show that all measured parameters remained within range during this test. The test was validated by greater than $90 \%$ survival of $H$. sculpta in each of the $0 \%$ SPP preparations for each test. The results of the test are summarized in Table 3.29 and show that survival was high at 100\% SPP in three of four treatments and in the Alcatraz site water exposures. In the reference treatment R-PC, survival in the $100 \%$ SPP was just over $50 \%$. Table 3.30 summarizes the statistical analysis of these data, and shows that treatments BC-4 and R-PC produced statistically significant differences, but no calculable LC50s.

\subsubsection{6-h Suspended-Particulate-Phase Static Test with Custigmaeus}

The results of the 96-h C. stigmaeus test are presented in Tables 3.31 and 3.32. A summary of the toxicological results for this test is provided in Volume 2, Appendix $\mathrm{N}$. Examination of the water quality data presented in Appendix N (Table N.3) shows that all measured parameters remained within the targeted range during this test. The results presented in Table 3.31 indicate the survival of $C$. stigmaeus in the $0 \%, 10 \%, 50 \%$, and $100 \%$ SPP concentrations. Two of the four $0 \%$ SPP concentrations were valid ( $>90 \%$ survival) and the overall average in the $0 \%$ SPP concentrations was greater than $90 \%$, thus validating the test. The C. stigmaeus showed no reduction in survival when exposed to the various concentrations of SPP. Survival in the $100 \%$ concentrations was equal to or greater than the survival found in the $0 \%$ concentrations; therefore, the test was not rerun. Survival was also high in SPP treatment concentrations and in the Alcatraz site water. Table 3.32 presents the t-test comparisons of control treatments to $100 \%$ SPP for each treatment, and shows that there were no significant differences within treatments. Because survival was greater than $77 \%$ in all SPP concentrations, LC50s were greater than $100 \%$ and could not be calculated.

\subsubsection{8-h Suspended-Particulate-Phase Static Test with Larval C gigas}

The results of the 48-h C. gigas test are presented in Tables 3.33 and 3.34. A summary of the toxicological results for this test is provided in Volume 2, Appendix $O$. Examination of the water quality data presented in Appendix $O$ (Table O.4) shows that all measured parameters remained within the targeted range during this test, with the exception of one low dissolved oxygen, measurement. This did not appear to influence test organism survival or test validity.

The results presented in Table 3.33 show that in most treatments, the mean percent survival was higher in the $0 \%$ to $50 \%$ SPP concentrations, averaging greater than $88 \%$, than it was in the $100 \%$ concentrations. In treatment BC-4, survival in the $100 \%$ SPP was less than $50 \%$ of that in control treatments $(0 \%)$. The mean percent of normal larvae development was generally within a 
TABLE 3.31. Results of the $C$. stigmaeus Suspended-Particulate-Phase Test

$\begin{array}{ccc}\begin{array}{c}\text { Sediment } \\ \text { Treatment }\end{array} & \begin{array}{c}\text { \% SPP } \\ \text { concentration }\end{array} & \begin{array}{c}\text { Mean } \\ \text { Percent } \\ \text { Survival }\end{array} \\ \text { BC-3 } & 0 & 86.7 \\ \text { BC-3 } & 10 & 96.7 \\ \text { BC-3 } & 50 & 96.7 \\ \text { BC-3 } & 100 & 93.3 \\ \text { BC-4 } & 0 & 87.1 \\ \text { BC-4 } & 10 & 76.7 \\ \text { BC-4 } & 50 & 76.7 \\ \text { BC-4 } & 100 & 90.0 \\ \text { R-PC } & 0 & 90.0 \\ \text { R-PC } & 10 & 83.3 \\ \text { R-PC } & 50 & 90.0 \\ \text { R-PC } & 100 & 90.3 \\ \text { C-SB } & 0 & 96.7 \\ \text { C-SB } & 10 & 90.0 \\ \text { C-SB } & 50 & 80.6 \\ \text { C-SB } & 100 & 100.0 \\ \text { Alcatraz } & 100 & 86.7\end{array}$

TABLE 3.32. T-Test and LC50 Determinations for the C. stigmaeus Test

\begin{tabular}{|c|c|c|c|c|c|}
\hline $\begin{array}{l}\text { Sediment } \\
\text { Treatment }\end{array}$ & $\begin{array}{l}\text { Table } \\
\text { t-value }\end{array}$ & d.f. & $\begin{array}{l}\text { Calculated } \\
\text { t-value }\end{array}$ & Significance $^{(a)}$ & $\begin{array}{c}\text { LC50 as } \\
\text { Percent SPP }\end{array}$ \\
\hline $\begin{array}{l}\text { BC-3 } \\
\text { BC-4 } \\
\text { R-PC } \\
\text { C-SB }\end{array}$ & $\begin{array}{l}2.776 \\
2.776 \\
2.776 \\
2.776\end{array}$ & $\begin{array}{l}4 \\
4 \\
4 \\
4\end{array}$ & $\begin{array}{r}-0.8944 \\
0.0000 \\
-0.3162 \\
-1.0000\end{array}$ & $\begin{array}{l}\text { NS(b) } \\
\text { NS } \\
\text { NS } \\
\text { NS }\end{array}$ & $\begin{array}{l}>100(c) \\
>100 \\
>100 \\
>100\end{array}$ \\
\hline
\end{tabular}

(a) At $\alpha=0.05$ for two sample $t$-test comparisons of $0 \%$ and $100 \%$ SPP.

(b) Not significant $(\alpha=0.05)$.

(c) Test organism survival was $>50 \%$ in all concentrations.

few percentage points of the percent survival, suggesting that most of the larvae that were recovered at the end of the test were normal. Table 3.34 presents the results of two sample t-tests, comparing the $0 \%$ and $100 \%$ survivals for each treatment. This table shows that there were Significant differences in survival between the $0 \%$ and $100 \%$ SPP concentrations in the BC-4 and 
TABLE 3.33. Results of the $C$, gigas Suspended-Particulate-Phase Test

$\begin{array}{lccc}\begin{array}{c}\text { Sediment } \\ \text { Treatment }\end{array} & \begin{array}{c}\text { \% SPP } \\ \text { Concentration }\end{array} & \begin{array}{c}\text { Mean } \\ \text { Percent } \\ \text { Survival }\end{array} & \begin{array}{c}\text { Mean } \\ \text { Percent } \\ \text { Normal }\end{array} \\ \text { BC-3 } & 0 & 89 & 88 \\ \text { BC-3 } & 10 & 90 & 89 \\ \text { BC-3 } & 50 & 85 & 85 \\ \text { BC-3 } & 100 & 80 & 78 \\ & & 94 & 93 \\ \text { BC-4 } & 0 & 95 & 95 \\ \text { BC-4 } & 10 & 90 & 89 \\ \text { BC-4 } & 50 & 41 & 0 \\ \text { BC-4 } & 100 & 95 & 95 \\ \text { R-PC } & 0 & 87 & 86 \\ \text { R-PC } & 10 & 88 & 87 \\ \text { R-PC } & 50 & 82 & 81 \\ \text { R-PC } & 100 & 85 & 75 \\ \text { C-SB } & 0 & 77 & 77 \\ \text { C-SB } & 10 & 79 & 85 \\ \text { C-SB } & 50 & 90 & \end{array}$

TABLE 3.34. T-Test and LC50 Determinations for C. gigas Test Based on Percent Survival

$\begin{array}{lcccccc}\begin{array}{l}\text { Sediment } \\ \text { Treatment }\end{array} & \begin{array}{c}\text { Table } \\ \text { t-value }\end{array} & \text { d.f. } & \begin{array}{c}\text { Calculated } \\ \text { t-value }\end{array} & \text { Significance(a) } & \begin{array}{c}\text { LC50 as } \\ \text { Percent SPP }\end{array} \\ \text { BC-3 } & 2.447 & 6 & 2.1230 & \text { NS(b) } & >100(\text { c) } \\ \text { BC-4 } & 2.447 & 6 & 5.4955 & \text { S(d) } & 91.9 \\ \text { R-PC } & 2.571 & 5 & 2.6597 & \text { S } & >100 \\ \text { C-SB } & 2.447 & 6 & 0.5343 & \text { NS } & >100\end{array}$

(a) At $\alpha=0.05$ for two sample t-test comparisons of $0 \%$ and $100 \%$ SPP.

(b) Not significant $(\alpha=0.05)$.

(c) Test organism survival was $>50 \%$ in all concentrations.

(d) Significant.

R-PC treatments. An LC50 could be calculated for only one treatment, BC-4, and indicated that $91.9 \%$ of SPP was required to reduce larval survival in the test to $50 \%$ relative to the $0 \%$ control. 


\subsection{BIOACCUMULATION}

Contaminants of concern were measured in the tissues of $M$. nasuta and $N$. caecoides after the 28-day exposure to test, reference, and control sediment treatments. These contaminants were PAHs, PCBs, pesticides, metals, and butyltins. The tissue chemistry results and the statistical analyses were performed using Dunn's Test for comparison of all means $(\alpha=0.1)$, and are summarized in the following sections. Dunn's Test is a conservative model that uses an experiment wide error rate and allows comparison of all possible treatment combinations. During this analysis, test treatments were omitted from the statistical comparison if all replicate tissue values for a contaminant of concern were undetected. Following the guidelines set forth in the Draft Implementation Manual, tissue-associated contaminants from test treatments are compared to references for the purpose of detecting elevated levels of contaminants in tissues. Consequently, all reference treatments are used for the statistical analysis, even if all replicates of the references are undetected. The detection limit values were used for undetected values in both reference treatments and test treatments. If all replicates of a test treatment produced undetected values, then the treatment was not statistically analyzed. Stations AC-1 and AC-3 were only tested with $M$. nasuta for tissue bioaccumulation; stations I-C3 and I-T5 were only tested with $N$. caecoides for tissue bioaccumulation. Pesticides for $M$. nasuta were analyzed using Dunn's Test and no statis'ical differences were found between reference treatments and test treatments. All data pertaining to the bioaccumulation tests may be found in Volume 2, Appendixes $\mathrm{P}$ and $\mathrm{Q}$.

\subsubsection{Polynuclear Aromatic Hydrocarbon Bioaccumulation in M. nasute}

Complete $M$. nasuta tissue chemistry data in both wet and dry weight PAH concentrations, quality control data, and quality control summaries are contained in Volume 2, Appendix P, Tables P.1 through P.11. The mean concentrations of PAHs ( $\mu \mathrm{g} / \mathrm{kg}$ dry weight) are presented in Table 3.35 and Table 3.36. Statistical comparisons were performed on all PAH compounds. The mean concentrations of PCBs $(\mu \mathrm{g} / \mathrm{kg}$ dry weight) are presented in Table 3.35.

Table 3.37 summarizes the results of Dunn's Test and demonstrates the relationship of $M$. nasuta tissue PAH levels in each reference treatment to each other as well as to the test treatments. This table shows that eight PAH compounds had significantly higher concentrations of PAHs in $M$. nasuta tissues exposed to the test treatments relative to at least one reference treatment. Naphthalene, acenapthylene, acenapthene, fluorene, anthracene, indeno(1,2,3-cd)pyrene, arid dibenzo(a,h)anthracene showed no significant elevation in any test treatments above reference treatments in $M$. nasuta tissues. PAHs were not present in significant levels relative to any reference treatment in $M$. nasuta tissue exposed to sediment from $\mathrm{I}-\mathrm{C} 4, \mathrm{I}-\mathrm{C} 5, \mathrm{I}-\mathrm{C} 7, \mathrm{I}-\mathrm{C} 8, \mathrm{I}-\mathrm{C}$, 


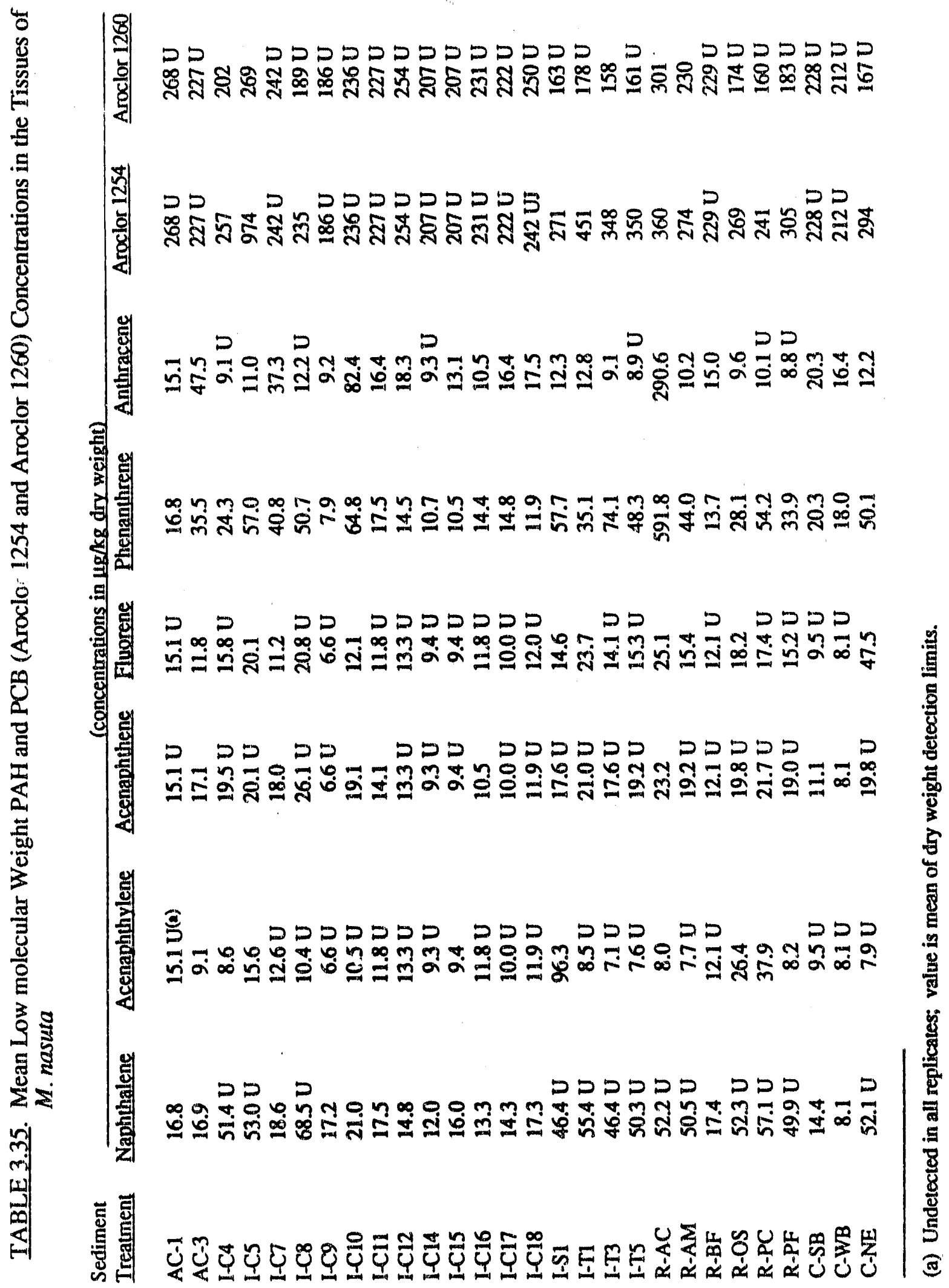




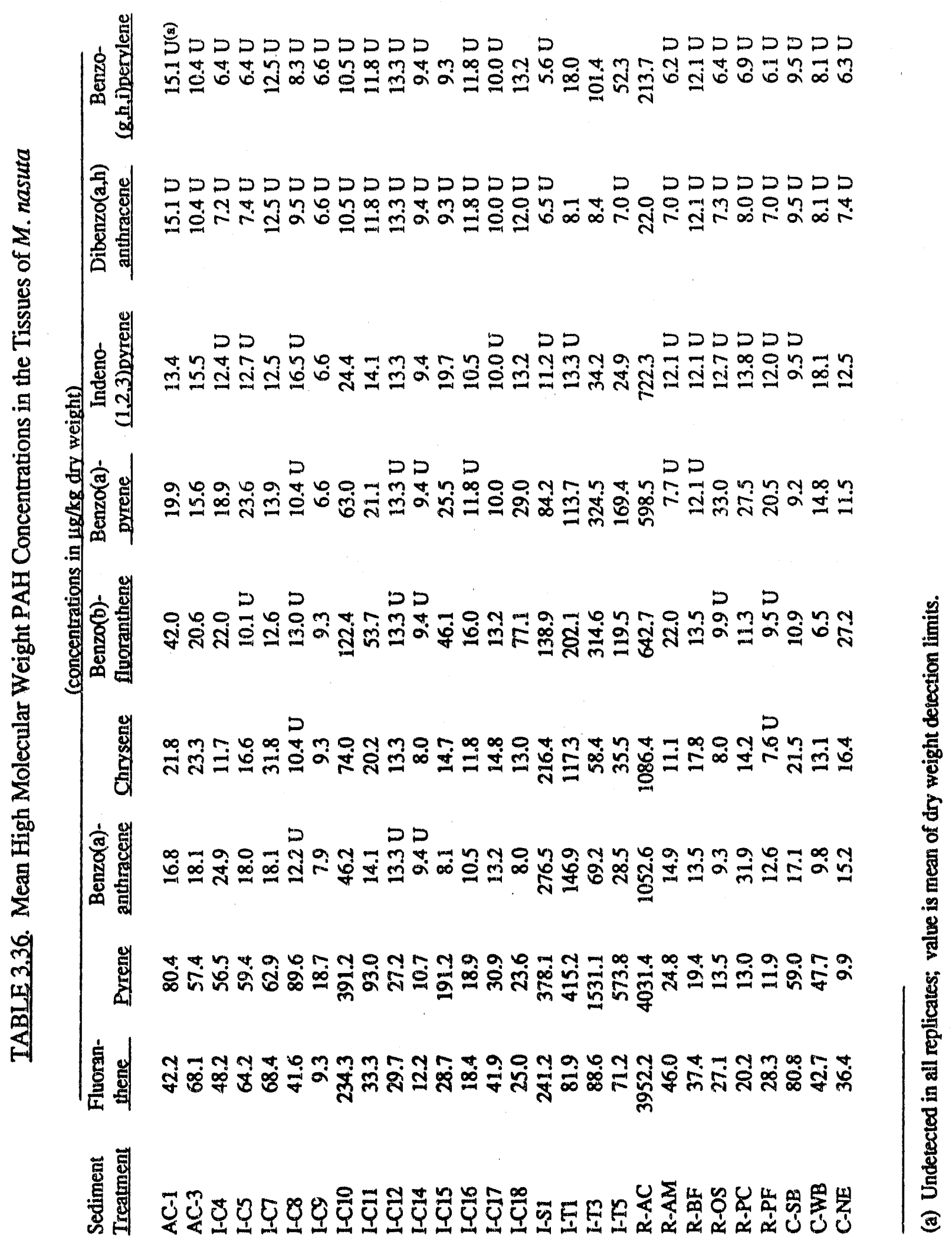

PHASEIIIA 
TABLE 3.37. PAHs and PCBs in Tissues of $M$. nasuta That Are Significantly Different from Reference Tissue Concentrations Using Dunn's Test for Comparison of All Means Analysis (bold numbers are treatment mean concentrations in $\mu \mathrm{g} / \mathrm{kg}$ dry weight)

Sediment Treatment and

Mean Tissue Concentration

(ug/kg dry weight)

Naphthalene

$\frac{R-A C}{52.2 \text { U }} \frac{R-A M}{50.5 \text { U }} \frac{R-B F}{17.4} \frac{R-O S}{52.3 \text { U }} \frac{R-P C}{57.1}$ U $\frac{R-P E}{49.9 ~ U}$

None are significantly different

Acenapthylene

8.0

$7.7 \mathrm{U}$

$12.1 \mathrm{U} \quad 26.4$

37.9

8.2

None are significantly different

Acenapthene

$23.2 \quad 19.2 \mathrm{U}$

$12.1 \mathrm{U}$

$19.8 \mathrm{U}$

$21.7 \mathrm{U}$

$19.0 \mathrm{U}$

None are significantly different

Eluorene

$25.1 \quad 15.4$

$12.1 \mathrm{U} \quad 18.2$

$17.4 \mathrm{U}$

$15.2 \mathrm{U}$

None are significantly different

Phenanthrene 591.8

44.0

13.7

28.1

54.2

33.9

I-T3

74.1

$$
--
$$

Anthracene

$290.6 \quad 10.2 \quad 15.0$

$S(b)$

None are significantly different

Eluoranthene

I-C10

I-S1

Pyrene

I-C10
I-C15
I-S1
I-T1
I-T3
I-T5

$$
3952.2 \quad 46.0
$$

234.3

241.2
37.4

S

4031.4

391.2

191.2

378.1

415.2

1531.1

573.8

\section{$-$.}

$\cdots$

$\mathrm{S}$
$\mathrm{S}$
$\mathrm{S}$
$\mathrm{S}$
$\mathrm{S}$
$\mathrm{S}$

19.4

$\mathrm{S}$
$\mathrm{S}$
$\mathrm{S}$
$\mathrm{S}$
$\mathrm{S}$
$\mathrm{S}$

13.5

13.0

11.9

$S$
$S$
$S$
$S$
$S$
$S$

$S$
$S$
$S$
$S$
$S$
$S$ 
TABLE 3.37. (Contd)

Sediment Treatment and

Mean Tissue Concentration

(14g/kg dry weight)

Benzo(a)anthracene

R-AC R-AM

I-C10

I-S1

I-T1

I-T3

$\begin{array}{rrr}46.2 & \ldots & \ldots \\ 276.5 & \ldots & S \\ 146.9 & \ldots & S \\ 69.2 & \ldots & S\end{array}$

$14.9 \quad 13.5$

$\frac{R-O S}{9.3} \frac{R \cdot P C}{31.9} \frac{R-P E}{12.6}$

Chrysene

1086.4

11.1

$S$
$S$

$\mathrm{S}$
$\mathrm{S}$
$\mathrm{S}$
$\mathrm{S}$

$\begin{array}{cc}\cdots & \cdots \\ \mathrm{S} & \mathrm{S} \\ \cdots & \mathrm{S}\end{array}$

I-C10

I-S1

I-T1

74.0

I-T3

I-T5

$\begin{array}{lr}\ldots- & S \\ \cdots & S \\ \cdots & S \\ \cdots- & S \\ \cdots & -\cdots\end{array}$

17.8

8.0

14.2

$7.6 \mathrm{U}$

Benzo(b)fluoranthene

$642.7 \quad 22.0$

$\begin{array}{cc}\cdots & S \\ S & S \\ -.- & S \\ \cdots & S\end{array}$

$\mathrm{S}$
$\mathrm{S}$
$\mathrm{S}$
$\mathrm{S}$
-

$S$
$S$
$S$
$S$
$S$

I-C10

I-C18

I-S 1

I-T1

I-T3

122.4

$\ldots \quad S$

13.5

$9.9 \mathrm{U} \quad 11.3$

$9.5 \mathrm{U}$

I-T5

77.1
138.9
202.1
314.6
119.5

Benzolalpyrene:

38.9

$\cdots$

$\cdots$

$\cdots$

$\ldots$

$S$
$-\cdots$
$S$
$S$
$\cdots-\cdots$

$S$
$-\cdot$
$S$
$S$
$S$
--

$\mathbf{S}$
$\mathbf{S}$
$\mathbf{S}$
$\mathbf{S}$
$\mathbf{S}$
$\mathbf{S}$

$S$
$S$
$S$
$S$
$S$
$S$

$\mathbf{S}$
$\mathbf{S}$
$\mathbf{S}$
$\mathbf{S}$
$\mathbf{S}$
$\mathrm{S}$

I-S1

I-T1

I-T3

598.5

7.7 U

$12.1 \mathrm{U}$

33.0

27.5

20.5

I-T5

$\begin{array}{rrr}84.2 & \cdots & S \\ 113.7 & \cdots & S \\ 324.5 & \cdots & S \\ 169.4 & \cdots- & S\end{array}$

$\cdots$
$\mathrm{S}$
$\mathrm{S}$

$\begin{array}{cc}\cdots & \cdots \\ -\cdots & \text { S } \\ -\cdots & \cdots\end{array}$

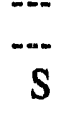

Indeno(1.2.3-cd)pyrene $\quad \mathbf{7 2 2 . 3}$

$12.1 \mathrm{U}$

$12.1 \mathrm{U}$

$12.7 \mathrm{U}$

$13.8 \mathrm{U}$

$12.0 \mathrm{U}$

None are significantly different

Dibenzo(a.h)anthracene $\quad \mathbf{2 2 . 0}$

$\begin{array}{lllll}7.0 & \mathrm{U} & 12.1 & \mathrm{U}\end{array}$

$7.3 \mathrm{U}$

$8.0 \mathrm{U}$

$7.0 \mathrm{U}$

None are significantly different

B

I-T3

I-T5

213.7

$6.2 \mathrm{U}$

$12.1 \mathrm{U}$

$6.4 \mathrm{U}$

$6.9 \mathrm{U}$

$6.1 \mathrm{U}$

$\begin{array}{rr}101.4 & \ldots \\ 52.3 & \cdots\end{array}$

S

$\mathrm{S}$

$\mathrm{S}$

$\mathrm{S}$

S 
TABLE 3.37. (Contd)

Sediment Treatment and

Mean Tissue Concentration

(4kg/kg dry weight)

R-AC B-AM

B.BF

$\frac{R-Q S}{269} \frac{R \cdot P C}{241} \frac{-R \cdot P F}{305}$

Arocler 1254

360

274

$229 \mathrm{U}$

None are significantly different

Aroclor 1260

3012230

$229 \mathrm{U}$

$174 U$

$160 \mathrm{U}$

$183 U$

None are significantly different

(a) Not significant $(\alpha=0.1)$.

(b) Significant $(\alpha=0,1)$.

1-C11, I-C12, I-C14, I-C16, and I-C17. Sediment treatments located within the tusing basin had elevated $\mathrm{PAH}$ levels relative to at least one reference site.

Results of ANOVA and Dunn's Test statistical analysis that compare the mean tissue concentrations and the statistical groupings for individual compounds are presented in Volume 2, Appendix R, Tables R.1 through R.26.

\subsubsection{Pesticide and PCB Bioaccumulation in $M$, nasuta}

Complete $M$. nasuta tissue chemistry data for wet and dry weight pesticide and PCB concentrations, quality control data, and quality control summaries are contained in Volume 2, Appendix P, Tables P.12 through P.24. Eighteen pesticides and two PCBs were analyzed using Dunn's Test and the ANOVA; results can be found in Volume 2, Appendix R, Tables R.27 through R.30. These statistical tests indicate no significantly higher concentration of pesticides and PCBs in any test treatment relative to the reference treatments. The measured concentrations of pesticides in these tissue samples should be qualified because of a tendency of some pesticides to coelute with some PCB congeners. Although a confirmatory analysis was conducted on pesticide samples in the test treatments where both aroclors and low concentrations of pesticides were found, pesticide results should be qualified as possibly being coeluted PCB peaks.

\subsubsection{Metals Bioaccumulation in $M$ nasuta}

Complete $M$. nasuta tissue chemistry data for wet and dry weight metals concentrations, quality control data, and quality control summaries are contained in Volume 2, Appendix P, Tables P.25 through P.27. Mean metals concentrations in the tissues of $M$. nasuta, expressed in

PHASEIIIA $\quad 3.73$ 
$\mathrm{mg} / \mathrm{kg}$ dry weight, are presented in Table 3.38. This table also shows the ratio of the highest concentration to the lowest for all test, reference, and control treatments to indicate the range of mean tissue values. The mean concentrations of all the metals varied by a factor of less than 5.3 .

The results of Dunn's Test are summarized in Table 3.39. 'This table shows that all metals except $\mathrm{Cd}, \mathrm{Hg}, \mathrm{Se}$, and $\mathrm{Zn}$ were elevated in $M$. nasuta tissues exposed to test treatments relative to at least one reference treatment. Statistically elevated concentrations of $\mathrm{Cr}$ were found in all of the test treatments when compared to R-AM. Silver concentrations were found to be elevated in test treatments AC-1, AC-3, I-C9, and I-C14 when compared to R-PC. Tissues exposed to sediment treatments I-C16 and I-T1 had significantly elevated As concentrations relative to R-OS. The results of ANOVA and Dunn's Test comparing mean $M$. nasuta tissue concentrations and statistical groupings for individual PAHs are presented in Volume 2, Appendix R, Tables R.31 through R.50.

\subsubsection{Butyltin Bioaccumulation in M nasuta}

Complete $M$. nasuta tissue chemistry data for wet and dry weight butyltin concentrations, quality control data, and quality control summaries are contained in Volume 2, Appendix $P$, Tables P.28 and P.30. Mean butyltin concentrations ( $\mu \mathrm{g} / \mathrm{kg}$ dry weight) in $M$. nasuta tissues exposed to reference, control, and test treatments are summarized in Table 3.40.

Table 3.41 presents the results of the Dunn's Test for butyltin concentrations in M. nasuta. Tributyltin concentrations were elevated in tissues exposed to test sediments I-T1, I-T3, and I-T5 relative to at least one reference treatment. Dibutyltins were significantly elevated in I-T5 relative to R-OS, R-PC, and R-PF. 'There were no significant elevations of monobutyltin in any of the test treatments. The ANOVA and Dunn's Test results for comparison of mean butyltins in $M$. nasuta tissues are presented in Volume 2, Appendix R, Tables R.51 through R.56. These tables show the relationship of reference treatments to each other as well as to test treatments.

\subsubsection{Polynuclear Aromatic Hydrocarbons Bioaccumulation in $N$. caecoides}

Complete $N$. caecoides tissue chemistry data for wet and dry weight PAH concentrations, quality control data, and quality control summaries are contained in Volume 2, Appendix $Q$, Tables Q.1 through Q.9. Nine of the 16 PAH compounds were detected in $N$. caecoides tissue samples. The mean concentrations $(\mu \mathrm{g} / \mathrm{kg}$ dry weight) of PAHs present in the tissues of $N$. caecoides are presented in Tables 3.42 and 3.43. Statistical comparisons were performed only on those PAH compounds that were detected. 
TABLE 3.38. Mean Metals Concentrations in the Tissues of $M$. nasuta

Sediment

Treatment

AC-1

AC-3

$\mathrm{I}-\mathrm{C} 4$

I-C5

I-C7

I-C8

I-C9

I-C10

I-C11

I-C12

$\mathrm{I}-\mathrm{C} 14$

I-Cl5

I-C16

I-C17

I-C18

I-S1

I-T1

I-T3

I-T5

R-AC

R-AM

$\mathrm{R}-\mathrm{BF}$

R-OS

R-PC

R-PF

C-SB

C-WB

C-NE

\begin{tabular}{|c|c|c|c|c|c|c|c|c|c|}
\hline$\overline{\mathrm{Ag}}$ & As & $\mathrm{Cd}$ & $\mathrm{Cr}$ & $-\mathrm{uti}$ & $\mathrm{Hg}$ & $\mathrm{Ni}$ & $\mathrm{Pb}$ & Se & $\mathrm{Zn}$ \\
\hline & .90 & 0. & & 28 & 0.06 & 5. & 4.74 & 1.77 & 12 \\
\hline & & & & & & & 3.12 & $\because$ & 127 \\
\hline & 20.9 & 0.20 & 4.22 & & 0.06 & 6.4 & 1.37 & 1 & 104 \\
\hline 8 & 24.07 & 0.26 & 3.39 & & $0.0^{\prime}$ & 5.7 & 1.97 & 1.62 & 117 \\
\hline & 18.99 & 0.19 & 4.15 & 16 & 0.05 & 5.0 & 1.33 & 1.53 & 104 \\
\hline & 21.10 & 0.33 & 3.20 & & 0.06 & 6.15 & 1.21 & 1.40 & 124 \\
\hline & 16.06 & 0.24 & 4.5 & & 0.05 & 17.01 & 3.29 & 1.46 & 122 \\
\hline 8 & 17.77 & 0.23 & 4.4 & & 0.06 & & 2.83 & 1.57 & 127 \\
\hline & 18.32 & 0.34 & 5.0 & & 0.06 & 5. & 3.75 & 1.60 & 117 \\
\hline & 19.05 & 0.22 & 3.1 & & 0. & 5. & 1.47 & 1.69 & 129 \\
\hline & 18.88 & 0.34 & 2.79 & & 0. & 5. & 3.76 & 1.69 & 107 \\
\hline 69 & 18.2 & 24 & 3. & & 0. & 5. & 2.68 & 1.57 & 115 \\
\hline & 24.15 & 0.8 & 2. & & & & & & 102 \\
\hline & 18.21 & 0.17 & 2.8 & & 0. & 5.3 & 4.01 & 1.53 & 94 \\
\hline 9 & 16.99 & 0.31 & 2. & & 0.09 & 4.9 & 2.72 & 1.59 & 123 \\
\hline & 19. & 0. & 3. & & & & & & 123 \\
\hline 0.7 & 25.05 & 0.3 & 3.5 & & 0. & 6. & 2.21 & 1.71 & 149 \\
\hline 20 & 16. & 0. & & & 0 & & 3. & 1.39 & 121 \\
\hline 0 & 15. & 0. & 3. & & & & & 1.45 & 110 \\
\hline 0.8 & 18.33 & 0.42 & 3.3 & & 0. & 7. & 2 & 1.69 & 122 \\
\hline 08 & 21. & 0.2 & 1. & & 0 & 3. & 1.36 & 1.58 & 128 \\
\hline & 18. & 0.2 & 4. & & & & 3.49 & 1.76 & 146 \\
\hline 0. & 15.09 & 0.4 & 2. & & 0. & 5. & 1. & 1. & 132 \\
\hline (1) & 16. & 0.4 & 3. & & & 5. & 1.29 & 1.72 & 126 \\
\hline 0 . & 17. & 0.4 & 3. & & 0. & 5. & 1.48 & 1.52 & 124 \\
\hline & & 0. & & & 0. & 4. & 3.1 & 1.6 & 116 \\
\hline 1. & 20.9 & 0.3 & 2. & 21 & 0. & 3.83 & 1.20 & 1.75 & 102 \\
\hline 0 & 24.06 & 0.35 & 1 & & 0.08 & 5.04 & 1.31 & 1.59 & 118 \\
\hline
\end{tabular}

Ratio of

Highest

Concentration

to Lowest

$\begin{array}{lll}1.8 & 1.7 & 2.9\end{array}$

4.8

$3.7 \quad 1.8$

5.3

$\begin{array}{lll}4.0 & 1.3 & 1.6\end{array}$

The results of Dunn's Test are summarized in Table 3.44. This table reveals that two PAHs, benzo(a)anthracene and benzo(b)fluoranthene, showed no significart elevations in $N$. caecoides tissues from any test treatment relative to reference treatments. The two PAHs, naphthalene (LPAH) and pyrene (HPAH), contain the most incidences of elevated levels in the tissues exposed to test treatments when compared to the references. Results of ANOVA and Dunn's Tests comparing mean $N$. caecoides tissue concentrations and statistical groupings for individual PAHs are presented in Volume 2, Appendix S, Tables S.1 through S.18. These tables show the relationship of $N$. caecoides tissue levels in each reference treatment to each other as well 
TABLE 3.39. Metals in Tissues of $M$. nasuta That Are Significantly Different from Reference Tissue Concentrations Using Dunn's Test for Comparison of All Means Analysis (bold numbers are treatment mean concentrations in $\mu \mathrm{g} / \mathrm{kg}$ dry weight)

Sediment Treatment and Mean Tissue Concentration (mg/kg dry weight) $\frac{R-A C}{0.8} \frac{R-A M}{0.8} \frac{R-B F}{1.1} \frac{R-O S}{0.7} \frac{R-P C}{0.6} \frac{R-P E}{0.7}$

Silver

$$
-\ldots-(\text { a) } \quad \cdots
$$

$\begin{array}{ll}\text { AC-1 } & 1.1 \\ \text { AC-3 } & 1.1 \\ \text { I-C9 } & 1.0 \\ \text { I-C14 } & 1.1\end{array}$

Arsenic

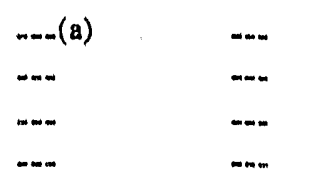

18.33

21.80

18.18

$\cdots$

$\begin{array}{ccc}\cdots & \cdots & \cdots\end{array}$

15.09

0.6

0.7

$\begin{array}{ll}\text { I-C16 } & \mathbf{2 4 . 1 5} \\ \text { I-T1 } & \mathbf{2 5 . 0 5}\end{array}$

Cadmium

$$
0.42
$$

0.25

0.29

0.47

0.49

0.45

None are significantly different

Chromium

AC-1

AC-3

I-C4

I-C5

I-C7

I-C8

I-C 9

I-C10

I-C11

I-C12

I-C14

I-C15

I-C16

I-C17

I-C18

I-S1

I-T1

I-T3

I-T5

Copper

I-C14

\subsection{8}

4.36

3.63

4.22

3.39

4.15

3.20

4.53

4.49

5.05

3.12

2.79

3.65

2.53

2.86

2.85

3.95

3.51

3.80

3.66

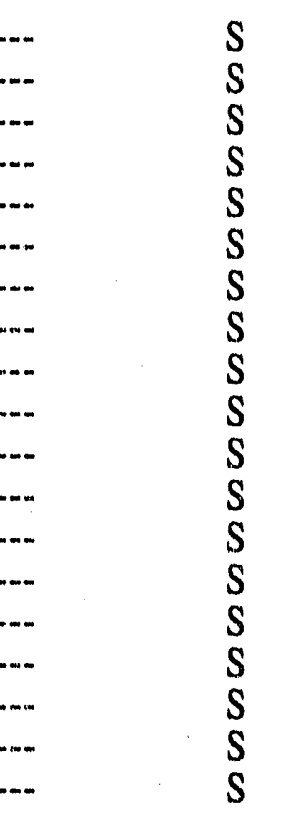

18.0

$S$

$S$

18.6

48.0

PHASE UIA
22.3

19.9

17.7

24.1

\subsection{5}

2.91

3.56

\begin{tabular}{|c|c|c|c|}
\hline$\cdots$ & -. & $\ldots$ & $\cdots$ \\
\hline-- & -- & $\cdots$ & $\cdots$ \\
\hline 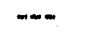 & -- & $\cdots$ & -.- \\
\hline -.- & $\cdots$ & --- & $\cdots$ \\
\hline$\cdots$ & -- & $\cdots$ & $\cdots$ \\
\hline 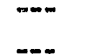 & 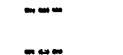 & $\cdots$ & $\cdots$ \\
\hline ... & ... & $\ldots$ & ... \\
\hline$\cdots$ & $\cdots$ & $\cdots$ & - \\
\hline - & -- & $\cdots$ & -.. \\
\hline$\cdots$ & $\cdots$ & $\cdots$ & $\cdots$ \\
\hline & $\cdots$ & $\cdots$ & $\cdots$ \\
\hline- & ... & -.. & -.. \\
\hline & $\ldots$ & $\cdots$ & --. \\
\hline - - & $\cdots$ & $\cdots$ & $\cdots$ \\
\hline & $\cdots$ & $\cdots$ & $\cdots$ \\
\hline -- & $\ldots$ & $\ldots$ & ... \\
\hline 22.3 & 19.9 & 17.7 & 24.1 \\
\hline & $S$ & $S$ & $\cdots$ \\
\hline
\end{tabular}

3.78 
TABLE 3.39. (Contd)

Sediment Treatment and

Mean Tissue Concentration

(m)/kg dry weight)

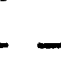

Mercury

B-AC R-AM - R-BE R-OS R-PC R-PE

None are significantly different

Nickel

7.22

3.24

6.08

5.72

5.40

5.69

I-C4

I-C9

I-S1

I-T1

I-T3

I-T5

Lead

AC-1

I-T3

6.40
17.01
8.43
6.37
7.00
6.69

Selenium

4.74

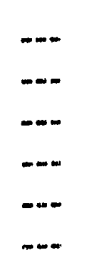

2.70

1.36

3.49

1.23

1.29

1.48

$\cdots$

1.69

1.58

1.76

1.87

1.72

1.52

None are significantly different

Zinc

None are significantly different

(a) Not significant $(\alpha=0.1)$.

(b) Significant $(\alpha=0.1)$.

as to the test treatments. The consistently high naphthalene concentrations occur in essentially all of the test, reference, and control sediment treatments. This level of naphthalene or naphthalenelike compound does not appear to be related to sediment contamination levels or laboratory contamination.

\subsubsection{Pesticide and PCB Bioaccumulation in $N$, caecoides}

Complete $N$. caecoides tissue chemistry data for wet and dry weight pesticide and PCB concentrations, quality control data, and quality control summaries are contained in Volume 2 , Appendix Q, Tables Q.10 through Q.19. Chlorinated pesticides were not statistically analyzed because of the few test treatments with detected pesticide levels. The mean concentrations $(\mu \mathrm{g} / \mathrm{kg}$ 
TABLE 3.40. Mean Butyltins Concentrations in the Tissues of $M$. nasuta

Sediment

Treatment

AC-1

AC-3

I-C4

I-C5

I-C7

I-C8

I-C9

I-C10

I-C11

I-C12

I-C14

I-C15

I-C16

I-C17

I-C18

I-S1

I-T1

I-T3

I-T5

R-AC

R-AM

R-BF

R-OS

R-PC

R-PF

C-SB

C-WB

C-NE

Tributyltin

19.6

16.2

22.1

13.8

11.8

15.5

14.1

22.6

23.1

14.9

10.7

19.0

11.2

13.1

22.3

23.3

28.2

100.6

252.0

80.8

30.4

19.0

15.9

10.0

18.2

16.4

13.2

27.7 (concentrations in $\mu \mathrm{g} / \mathrm{kg}$ dry weight)

Dibutyltin Monobutyltin

$\begin{array}{rr}9.3 & 4.0 \\ 45.5 & 2.4 \\ 10.6 & 2.7 \\ 8.4 & 4.8 \\ 7.6 & 2.8 \\ 8.9 & 3.5 \\ 11.5 & 2.9 \\ 11.3 & 3.6 \\ 21.5 & 12.5 \\ 12.9 & 9.3 \\ 13.7 & 7.1 \\ 10.2 & 3.3 \\ 13.1 & 3.7 \\ 9.7 & 5.0 \\ 14.9 & 7.2 \\ 9.2 & 3.0 \\ 10.9 & 3.4 \\ 16.4 & 3.2 \\ 29.9 & 4.0 \\ 15.9 & 3.8 \\ 24.1 & 4.0 \\ 12.3 & 5.1 \\ 8.7 & 2.7 \\ 7.3 & 3.4 \\ 9.7 & 4.2 \\ 10.8 & 3.0 \\ 8.8 & 2.9 \\ 16.1 & 5.2\end{array}$

dry weight) of Aroclor 1254 present in the tissues of $N$. caecoides are presented in Table 3.42. The test treatments with the high.sst mean concentrations of Aroclor 1254 were R-OS (1242.63 $\mu \mathrm{g} / \mathrm{kg})$ and $\mathrm{I}-\mathrm{T} 3(2268.52 \mu \mathrm{g} / \mathrm{kg})$.

Results of Dunn's Test analyzing Aroclor 1254 are summarized in Table 3.44. Tissues exposed to test treatment I-T3 had significantly elevated levels of Aroclor 1254 relative to all the references. The ANOVA and Dunn's Test results are presented in Volume 2, Appendix S, Tables S.19 and S.20. These tables show the relationship of $N$. caecoides tissue levels in each reference treatment to each other as well as to the test treatments. 
TABLE 3.41. Butyltins in Tissues of $M$. nasuta That Are Significantly Different from Reference Tissue Concentrations Using Dunn's Test for Comparison of All Means Analysis (bold numbers are treatment mean concentrations in $\mu \mathrm{g} / \mathrm{kg}$ dry weight)

Sediment Treatment and

Mean Tissue Concentration (ug/kg dry weight)

Tributylin

$\frac{R-A C}{80.8} \frac{R-A M}{30.4} \frac{R-B F}{19.0} \frac{R-O S}{15.9} \frac{R-P C}{10.0} \frac{R-P E}{18.2}$

I-T1

I-T3

I-T5

28.2

100.6

252.0

\begin{tabular}{l}
.$--(a)$ \\
\hline$S$
\end{tabular}

$\stackrel{\mathrm{S}}{\mathrm{S}}$

$\mathrm{S}$

$\stackrel{-}{S}$

$S(b)$
$S$
$S$

$\bar{S}$

Dibutyltin

$15.9 \quad 24.1$

12.3

8.7

7.3

9.7

I-T5

29.9

Monobutyltin

3.8

4.0

$\mathrm{S}$

$\mathrm{S}$

$\mathrm{S}$

None are significantly different

(a) Not significant $(\alpha=0.1)$.

(b) Significant $(\alpha=0.1)$.

\subsubsection{Metals Bioaccumulation in $N$ caecoides}

Complete $N$. caecoides tissue chemistry data for wet and dry weight metals concentrations, quality control data, and quality control summaries are contained in Volume 2, Appendix Q, Tables Q.20 through Q.22. Mean metals concentrations in the tissues of $N$. caecoides, expressed in $\mathrm{mg} / \mathrm{kg}$ dry weight, are presented in Table 3.45. This table also shows the ratio of the highest concentration to the lowest for all treatments to indicate the range of mean tissue values. The mean concentrations of most metals varied by a factor of less than 3.9. Three metals had larger concentration ranges in $N$. caecoides tissues: $\mathrm{Ag}$ varied by a factor of $8.0, \mathrm{Cr}$ by a factor of 5.5 , and $\mathrm{Hg}$ by a factor of 22.0 .

Table 3.46 presents the results of Dunn's Test with $N$. caecoides, which indicated As, $\mathrm{Cu}$, $\mathrm{Ni}$, and $\mathrm{Pb}$ were not significantly elevated in any test treatments when compared to the reference treatments. Cadmium was present in tissues exposed to test treatments I-C11, I-C15, I-C17, I-C18, and I-S1 in significant levels when compared to reference sediment R-PC. Tissues exposed to nine test treatments had significantly higher concentrations of $\mathrm{Cr}$ than R-PF; four test treatments had significantly higher concentrations of $\mathrm{Hg}$ than R-PC. The ANOVA and Dunn's Test results are presented in Volume 2, Appendix S, Tables S.21 through S.40.

\section{PHASE IIIA}


TABLE 3.42. Mean Low Molecular Weight PAH and PCB Aroclor 1254 Concentrations in the Tissues of $N$, caecoides

Sediment

Treatment

I-C3

I.C5

$\mathrm{I}-\mathrm{C} 7$

$\mathrm{I}-\mathrm{C} 8$

I-C9

I-C10

I-C11

I-C12

I-C14

I.C15

I-C16

I-C17

I-C18

I-S1

I-T1

I-T3

R*AC

R-AM

$\mathrm{R}-\mathrm{BF}$

R-OS

R-PC

R-PF

C-SB

C-NE

C-NE-A (concentrations in $\mu \mathrm{g} / \mathrm{kg}$ dry weight)

\begin{tabular}{|c|c|c|c|}
\hline $\begin{array}{l}\text { Anthra- } \\
\text { cene }\end{array}$ & Napthalene & $\begin{array}{l}\text { Phenan- } \\
\text { threne }\end{array}$ & $\begin{array}{c}\text { Aroclor } \\
1254 \\
\end{array}$ \\
\hline $50.89 U^{(a)}$ & 285.6 & $50.89 \mathrm{U}$ & $508.91 \mathrm{U}$ \\
\hline $53.43 \mathrm{U}$ & 283.8 & $53.43 \mathrm{U}$ & $534.33 \mathrm{U}$ \\
\hline $57.58 \mathrm{U}$ & 413.1 & 72.25 & $575.75 \mathrm{U}$ \\
\hline $55.02 \mathrm{U}$ & 379.6 & 55.02 & $550.16 \mathrm{U}$ \\
\hline $50.66 \mathrm{U}$ & 354.6 & 72.71 & $506.57 \mathrm{U}$ \\
\hline $55.03 \mathrm{U}$ & 357.7 & 59.53 & $550.27 \mathrm{U}$ \\
\hline $58.76 \mathrm{U}$ & $235.0 \mathrm{U}$ & 78.34 & $696.33 \mathrm{U}$ \\
\hline 54.36 & 354.6 & 77.46 & $515.84 \mathrm{U}$ \\
\hline $51.29 \mathrm{U}$ & $256.4 \mathrm{U}$ & 56.31 & $512.85 \mathrm{U}$ \\
\hline $61.38 \mathrm{U}$ & 439.6 & 114.10 & $990.56 \mathrm{U}$ \\
\hline $50.29 \mathrm{U}$ & 518.0 & 85.08 & $902.77 \mathrm{U}$ \\
\hline $51.49 \mathrm{U}$ & $360.4 \mathrm{U}$ & 60.75 & $859.64 \mathrm{U}$ \\
\hline $54.05 \mathrm{U}$ & 310.0 & 74.67 & $873.39 \mathrm{U}$ \\
\hline 105.60 & 259.6 & 279.80 & 810.15 \\
\hline $51.50 \mathrm{U}$ & 389.5 & 69.32 & $775.40 \mathrm{U}$ \\
\hline 54.25 & 471.9 & 103.40 & 2268.52 \\
\hline $57.80 \mathrm{U}$ & 141.1 & 188.70 & $578.03 \mathrm{U}$ \\
\hline $63.80 \mathrm{U}$ & 288.0 & 122.10 & $637.99 \mathrm{U}$ \\
\hline $62.01 \mathrm{U}$ & $124.0 \mathrm{U}$ & 125.28 & 820.42 \\
\hline $67.36 \mathrm{U}$ & $134.7 \mathrm{U}$ & 105.20 & 1242.63 \\
\hline $64.22 \mathrm{U}$ & $128.4 \mathrm{U}$ & 118.33 & 885.21 \\
\hline $59.62 \mathrm{U}$ & $119.2 \mathrm{U}$ & 99.80 & $596.18 \mathrm{U}$ \\
\hline & 287.4 & 90.73 & $673.84 \mathrm{U}$ \\
\hline 78 & 323.5 & $78.83 \mathrm{U}$ & $788.27 \mathrm{U}$ \\
\hline 56.43 & 312.2 & 56.43 & $564.30 \mathrm{U}$ \\
\hline
\end{tabular}

(a) Undetected in all replicates; value is mean of dry weight detection limits.

\subsubsection{Butyltins Bioaccumulation in $N$ caecoides}

Complete $N$. caecoides tissue chemistry data for wet and dry weight butyltin concentrations, quality control data, and quality control summaries are contained in Volume 2, Appendix $Q$, Tables $Q .23$ and Q.25. Mean butyltin concentrations ( $\mu \mathrm{g} / \mathrm{kg}$ dry weight) in $N$. caecoides tissues exposed to test, reference, and control treatments are summarized in Table 3.47.

Table 3.48 presents the results of Dunn's Test for butyltin concentrations in $N$. caecoides. This table shows that elevated levels of tributyltin occurred in tissues exposed to test treatment I-T3 relative to all the reference treatments. Elevated levels of dibutyltin occurred in 
TABLE 3.43. Mean High Molecular Weight PAH Concentrations in Tissues of $N$. caecoides

\begin{tabular}{|c|c|c|c|c|c|c|}
\hline \multirow[b]{2}{*}{$\begin{array}{l}\text { Sediment } \\
\text { Treatment }\end{array}$} & \multicolumn{6}{|c|}{ (concentrations in $\mu \mathrm{g} / \mathrm{kg}$ dry weight) } \\
\hline & $\begin{array}{l}\text { Benzo(a)- } \\
\text { anthracene }\end{array}$ & $\begin{array}{l}\text { Benzo(b)- } \\
\text { fluoranthene }\end{array}$ & $\begin{array}{l}\text { Benzo(a)- } \\
\text { pyrene }\end{array}$ & Chrysene & $\begin{array}{l}\text { Fluoran- } \\
\text { thene }\end{array}$ & Pyrene \\
\hline I-C3 & $50.89 \mathrm{U}(\mathrm{a})$ & $50.89 \mathrm{U}$ & $50.89 \mathrm{U}$ & $50.89 \mathrm{U}$ & $50.89 \mathrm{U}$ & $50.89 \mathrm{U}$ \\
\hline I.C5 & $53.43 \mathrm{U}$ & $53.43 \mathrm{U}$ & $53.43 \mathrm{U}$ & $53.43 \mathrm{U}$ & 56.63 & 150.04 \\
\hline I-C7 & $57.58 \mathrm{U}$ & $57.58 \mathrm{U}$ & $57.58 \mathrm{U}$ & $57.58 \mathrm{U}$ & $57.58 \mathrm{U}$ & $57.58 \mathrm{U}$ \\
\hline I-C8 & $55.02 \mathrm{U}$ & $55.02 \mathrm{U}$ & $55.02 \mathrm{U}$ & $55.02 \mathrm{U}$ & 58.02 & 92.66 \\
\hline I-C.9 & $50.66 \mathrm{U}$ & $50.66 \mathrm{U}$ & $50.66 \mathrm{U}$ & $50.66 \mathrm{U}$ & 82.44 & 455.65 \\
\hline I-C10 & $56.08 \mathrm{U}$ & $56.08 \mathrm{U}$ & $56.08 \mathrm{U}$ & $56.08 \mathrm{U}$ & $92.24 \mathrm{U}$ & 2821.57 \\
\hline $\mathrm{I}-\mathrm{C} 11$ & $58.76 \mathrm{U}$ & $58.76 \mathrm{U}$ & $58.76 \mathrm{U}$ & $58.76 \mathrm{U}$ & 83.03 & 75.43 \\
\hline $\mathrm{I}-\mathrm{C} 12$ & $51.59 \mathrm{U}$ & $51.59 \mathrm{U}$ & $51.59 \mathrm{U}$ & $51.59 \mathrm{U}$ & $51.59 \mathrm{U}$ & 1403.07 \\
\hline I-C14 & $51.29 \mathrm{U}$ & $51.29 \mathrm{U}$ & $51.29 \mathrm{U}$ & $51.29 \mathrm{U}$ & $256.42 \mathrm{U}$ & 99.77 \\
\hline $\mathrm{I}-\mathrm{C} 15$ & $61.38 \mathrm{U}$ & $61.38 \mathrm{U}$ & $61.38 \mathrm{U}$ & 67.53 & 338.79 & 107.44 \\
\hline I-C16 & 51.24 & $50.29 \mathrm{U}$ & $50.29 \mathrm{U}$ & $50.29 \mathrm{U}$ & $251.44 \mathrm{U}$ & 62.15 \\
\hline I-C17 & $51.49 \mathrm{U}$ & $51.49 \mathrm{U}$ & $51.49 \mathrm{U}$ & $51.49 \mathrm{U}$ & 78.50 & 406.60 \\
\hline I-C18 & $54.05 \mathrm{U}$ & $54.05 \mathrm{U}$ & $54.05 \mathrm{U}$ & $54.05 \mathrm{U}$ & $270.27 \mathrm{U}$ & 56.27 \\
\hline $\mathrm{I}-\mathrm{S} 1$ & 116.32 & 115.27 & 325.30 & 656.02 & 958.66 & 2909.20 \\
\hline $\mathrm{I}-\mathrm{T} 1$ & $51.50 \mathrm{U}$ & $51.50 \mathrm{U}$ & $51.50 \mathrm{U}$ & 156.12 & 133.18 & 577.19 \\
\hline I-T3 & $51.20 \mathrm{U}$ & 83.87 & $51.20 \mathrm{U}$ & 224.06 & 186.24 & 1281.99 \\
\hline $\mathrm{R}-\mathrm{AC}$ & $57.80 \mathrm{U}$ & $57.80 \mathrm{U}$ & $57.80 \mathrm{U}$ & 57.80 & 197.31 & 321.93 \\
\hline R-AM & $63.80 \mathrm{U}$ & $63.80 \mathrm{U}$ & $63.80 \mathrm{U}$ & $63.80 \mathrm{U}$ & 142.91 & 127.40 \\
\hline R-BF & 74.93 & 67.18 & $62.01 \mathrm{U}$ & 91.73 & 121.43 & 126.39 \\
\hline R-OS & $67.36 \mathrm{U}$ & $67.36 \mathrm{U}$ & $67.36 \mathrm{U}$ & $67.36 \mathrm{U}$ & 94.16 & 90.10 \\
\hline R-PC & $64.22 \mathrm{U}$ & $64.22 \mathrm{U}$ & $64.22 \mathrm{U}$ & $64.22 \mathrm{U}$ & 113.95 & 100.66 \\
\hline R-PF & $59.62 \mathrm{U}$ & $59.62 \mathrm{U}$ & $59.62 \mathrm{U}$ & $59.62 \mathrm{U}$ & 119.64 & 99.09 \\
\hline C-SB & $67.38 \mathrm{U}$ & $67.38 \mathrm{U}$ & $67.38 \mathrm{U}$ & $67.38 \mathrm{U}$ & 97.64 & 75.8 \\
\hline C-NE & $78.83 \mathrm{U}$ & $78.83 \mathrm{U}$ & $78.83 \mathrm{U}$ & $78.83 \mathrm{U}$ & $78.83 \mathrm{U}$ & $78.83 \mathrm{U}$ \\
\hline $\mathrm{C}-\mathrm{NE}-\mathrm{A}$ & $56.43 \mathrm{U}$ & $=612 \pi$ & $56.43 \mathrm{U}$ & & $56.43 \mathrm{U}$ & $56.43 \mathrm{U}$ \\
\hline
\end{tabular}

(a) Undetected in all replicates; value is mean of dry weight detection limits.

tissues exposed to test treatments I-C15, I-C16, I-C18, and I-T3 when compared to the reference R-PC. Tissues exposed to test treatments I-C15 and I-C18 had significantly higher levels of monobutyltin than reference sediments R-AC, R-BF, R-PC, and R-PF. The ANOVA and Dunn's Test results are presented in Volume 2, Appendix S, Tables S.41 through S.46. 
TABLE 3.44. PAHs and PCBs in Tissues of $N$. caecoides That Are Significantly Different from Reference Tissue Concentrations Using Dunn's Test for Comparison of All Means Analysis (bold numbers are treatment mean concentrations in $\mu \mathrm{g} / \mathrm{kg}$ dry weight)

Sediment Treatment and

Mean Tissue Concentration

(ug/kg dry weight)

$R-A C$ R-AM R-BE $R-O S$ R-PC R-PE

Anthracene

$\begin{array}{llllllllllll}57.80 & \text { U } & 63.80 & \text { U } & 62.01 & \text { U } & 67.36 & \text { U } & 64.22 & \text { U } & 59.62 & \text { U }\end{array}$

I-S1 $\quad 105.6$

$S(a) \quad S$

$S$

$S$

$S \quad S$

Napthalene

$\begin{array}{llllllllll}141.1 & 288.0 & 124.0 & U & 134.7 & \text { U } & 128.4 & \text { U } & 119.2 & \text { U }\end{array}$

$\begin{array}{ll}\text { I-C3 } & \mathbf{2 8 5 . 6} \\ \text { I-C5 } & \mathbf{2 8 3 . 8} \\ \text { I-C7 } & \mathbf{4 1 3 . 1} \\ \text { I-C8 } & \mathbf{3 7 9 . 6} \\ \text { I-C9 } & \mathbf{3 5 4 . 6} \\ \text { I-C12 } & \mathbf{3 5 4 . 6} \\ \text { I-C15 } & \mathbf{4 3 9 . 6} \\ \text { I-C16 } & \mathbf{5 1 8 . 0} \\ \text { I-C18 } & \mathbf{3 1 0 . 0} \\ \text { I-S1 } & \mathbf{2 5 9 . 6} \\ \text { I-T1 } & \mathbf{3 8 9 . 5} \\ \text { I-T3 } & \mathbf{4 7 1 . 9}\end{array}$

Phenanthrene

I-S1 $\quad \mathbf{2 7 9 . 8 0}$

\begin{tabular}{|c|c|}
\hline$S$ & $\ldots$ \\
\hline$S$ & -.. \\
\hline$S$ & $\cdots$ \\
\hline$S$ & $\cdots$ \\
\hline S & $\cdots$ \\
\hline S & $\ldots$ \\
\hline$S$ & $S$ \\
\hline$S$ & $\cdots$ \\
\hline 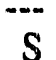 & $\cdots$ \\
\hline$S$ & -- \\
\hline
\end{tabular}

$S$
$S$
$S$
$S$
$S$
$S$
$S$
$S$
$S$
$S$
$S$
$S$

$\begin{array}{ll}\text { S } & \text { S } \\ \text { S } & \text { S } \\ \text { S } & \text { S } \\ \text { S } & \text { S } \\ \text { S } & \text { S } \\ \text { S } & \text { S } \\ \text { S } & \text { S } \\ \text { S } & \text { S } \\ \text { S } & \text { S } \\ \text { S } & \text { S } \\ \text { S } & \text { S }\end{array}$

$\begin{array}{llllll}188.70 & 122.10 & 125.28 & 105.20 & 118.33 & 99.80\end{array}$

Fluoranthene

$\begin{array}{llllll}197.31 & 142.91 & 121.43 & 94.16 & 113.95 & 119.64\end{array}$

I-C15

I-S1

338.79

958.66

$\mathrm{S}$

$\begin{array}{ll}S & S \\ S & S\end{array}$

S

S

S

Chrosene

$$
57.80
$$

$63.80 \cup 91.73$

67.36

$\begin{array}{llll} & 64.22 & \text { U } 59.62 & \mathrm{U}\end{array}$

I-S1

$\mathrm{I}-\mathrm{T} 1$

656.02

156.12

I-T3

224.06

$S$
$S$

$\mathrm{S}$
$\mathrm{S}$

$S$
$S$

$\mathrm{S}$
$\mathrm{S}$
$\mathrm{S}$

$\mathrm{S}$
$\mathrm{S}$
$\mathrm{S}$

$\mathrm{S}$
$\mathrm{S}$
$\mathrm{S}$

Benzo(a)anthracene

57.80

63.80

U 74.93

$67.36 \cup 64.22$

U 59.62 U

None are significantly different

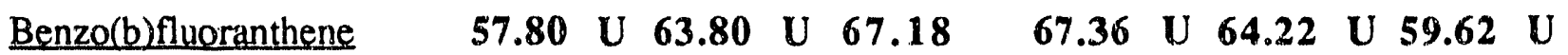

None are significantly different 
TABLE3.44. (Contd)

Sediment Treatment and

Mean Tissue Concentration

(le/kg dry weight)

$R-A C$ R-AM R-BF R-OS R-PC R-PE

Benzo(a)pyrene

$\begin{array}{llllllllllll}57.80 & \cup & 63.80 & \cup & 62.01 & U & 67.36 & \text { U } & 64.22 & \text { U } & 59.62 & \text { U }\end{array}$

$\begin{array}{llllllll}\text { I-S1 } & 325.3 & \text { S } & \text { S } & \text { S } & \text { S } & \text { S } & \text { S }\end{array}$

$\begin{array}{lllllll}\text { Pyrene } & 321.93 & 127.40 & 126.39 & 90.10 & 100.66 & 99.09\end{array}$

$\begin{array}{lrrrrrrr}\text { I-C9 } & \mathbf{4 5 5 . 6 5} & \cdots & \text { S } & \text { S } & \text { S } & \text { S } & \text { S } \\ \text { I-C10 } & \mathbf{2 8 2 1 . 5 7} & \text { S } & \text { S } & \text { S } & \text { S } & \text { S } & \text { S } \\ \text { I-C12 } & \mathbf{1 4 0 3 . 0 7} & \text { S } & \text { S } & \text { S } & \text { S } & \text { S } & \text { S } \\ \text { I-C17 } & \mathbf{4 0 6 . 6 0} & \cdots & \text { S } & \text { S } & \text { S } & \text { S } & \text { S } \\ \text { I-S1 } & \mathbf{2 9 0 9 . 2 0} & \text { S } & \text { S } & \text { S } & \text { S } & \text { S } & \text { S } \\ \text { I-T1 } & \mathbf{5 7 7 . 1 9} & \cdots-- & \text { S } & \text { S } & \text { S } & \text { S } & \text { S }\end{array}$

Aroclor 1254

$\begin{array}{lllllllll}578.03 & \text { U } 637.99 & \text { U } 820.42 & 1242.63 & 885.21 & 596.18 & U\end{array}$

I-T3 2268.52

$S \quad S$

$S$

$\mathrm{S}$

$\mathrm{S}$

$\mathrm{S}$

(a) Significant $(\alpha=0.1)$.
(b) Not significant $(\alpha=0.1)$. 
TABLE 3.45. Mean Metals Concentrations in the Tissues of $N$. caecoides

\begin{tabular}{|c|c|c|c|c|c|c|c|c|c|c|}
\hline \multirow{2}{*}{$\begin{array}{l}\text { Sediment } \\
\text { Treatment }\end{array}$} & \multicolumn{10}{|c|}{ (concentrations in $\mathrm{mg} / \mathrm{kg}$ dry weight) } \\
\hline & $\overline{\mathrm{Ag}}$ & $\overline{A s}$ & $c d$ & $c_{r}$ & Cu & $\mathrm{Hg}$ & $\mathrm{Ni}$ & $\mathrm{Pb}$ & $\mathrm{Se}$ & $\mathrm{Zn}$ \\
\hline [-C3 & 0.03 & 18.33 & 1.23 & 0.58 & 11.98 & 0.04 & 3.80 & 0.45 & $1.17 \mathrm{U}(\mathrm{a})$ & 167.83 \\
\hline & & & 1.20 & 0.67 & 11.93 & 0.04 & 1.80 & 0.99 & 190 & 172 \\
\hline & 05 & 18.07 & 1.16 & 0.68 & 11.94 & 0.04 & 2.66 & 0.49 & 1.01 & 174.13 \\
\hline C8 & 07 & 19.33 & 1.08 & 0.67 & 14.20 & 0.05 & 2.35 & 0.40 & 1.05 & 189.37 \\
\hline & & 10.36 & & 0.39 & 12.74 & 0.22 & 2.21 & 1.12 & & 41.60 \\
\hline & .03 & 18.33 & 1.19 & 0.58 & 11.35 & 0.03 & 2.54 & 0.97 & $0.98 \mathrm{U}$ & 88.17 \\
\hline & .05 & 13.69 & 1.60 & 0.51 & 12.40 & 0.17 & 3.97 & 0.49 & 1.75 & 262.00 \\
\hline & 3 & 20.70 & 1.17 & 0.58 & 12.01 & 0.03 & 2.43 & 0.99 & 1.09 & 175.63 \\
\hline 4 & 0.0 & 8.06 & 1.17 & 0.83 & 13.71 & 0.10 & 3.11 & 1.13 & 1.67 & 271. \\
\hline & 00 & 7.05 & 1.50 & 0.34 & 9.10 & 0.08 & 2.59 & 0.53 & 1.54 & 249 \\
\hline & 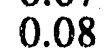 & 11.59 & 1.37 & 0.72 & 15.90 & 0.27 & 2.73 & 0.71 & 1.89 & 27 \\
\hline & & 10.99 & 1.47 & 0.75 & 18. & 0.11 & & 0.38 & 08 & \\
\hline & 0.0 & 10.29 & 1.40 & 0.38 & 13.46 & 0.25 & 2.3 & 1.14 & 1.45 & 297.00 \\
\hline & & 12.42 & 1.27 & 0.45 & 15 & 0.38 & 2.52 & 1.23 & 1.99 & 25 \\
\hline & & 6.99 & 1.17 & 0.43 & & 0.37 & & & & \\
\hline & & 26.63 & 1.0 & 0. & & & & & & 19 \\
\hline & 0.0 & 19.73 & 1.13 & 0.3 & 25 & 0.66 & 3. & 0.78 & 1.17 & 18 \\
\hline & & 22.77 & 1.13 & & & 0. & 3. & 0. & 1. & \\
\hline & & 22.7 & & & 13 & 0. & 3. & & & 198 \\
\hline & 0.1 & 19.70 & 0.8 & 0 & 10. & 0.07 & 2.5 & 0. & & 193.9 \\
\hline & & 20.23 & 1.0 & 0.15 & 12 & 0.19 & 2.47 & 0.61 & 1. & 184.5 \\
\hline & & 21.63 & 1.0 & 0.25 & 15 & 0. & & & 1.1 & \\
\hline & & 17. & & 0. & 15 & 0. & 2. & & & 18 \\
\hline $\mathrm{C}-\mathrm{N}$ & & 15.53 & 1 & 0.15 & 11.72 & 0.05 & 1.78 & 0.53 & 1.15 & 170.53 \\
\hline \multicolumn{11}{|l|}{$\begin{array}{l}\text { Ratio } \\
\text { Highe: }\end{array}$} \\
\hline & & & & & & & & & & \\
\hline to Lo & 8.0 & 3.9 & 2.0 & 5.5 & 2.8 & 2.0 & 2.2 & 3.2 & 2.2 & 1.8 \\
\hline
\end{tabular}

(a) Undetected in all replicates; value is mean of dry weight detection limits. 
TABLE 3,46. Metals in Tissues of $N$, caecoides That Are Significantly Different from Reference Tissue Concentrations Using Dunn's Test for Comparison of All Means Analysis (bold numbers are treatment mean concentrations in $\mu \mathrm{g} / \mathrm{kg}$ dry weight)

Sediment Treatment and

Mean Tissue Concentration (mg/kg dry weight)

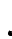

Silver

$\mathrm{R}-\mathrm{AC}$

R-AM

$\mathrm{R} \cdot \mathrm{BF}$

$\frac{\mathrm{R}-\mathrm{OS}}{0.06}$

$\frac{R-P C}{0.04} \frac{R-P E}{0.03}$

I-C18

$$
0.16
$$

$S(a)$

-...(b) $S$

$\mathrm{S}$

$\mathrm{S}$

$S$

Arsenic

$$
26.63
$$

19.73

22.77

22.77

19.70

20.23

None are significantiy different

Cadmium

\subsection{8}

1.13

1.13

1.08

0.82

1.04

$\begin{array}{ll}\text { I-C11 } & \mathbf{1 . 6 0} \\ \text { I-C15 } & \mathbf{1 . 5 0} \\ \text { I-C17 } & 1.37 \\ \text { I-C18 } & \mathbf{1 . 4 7} \\ \text { I-S1 } & \mathbf{1 . 4 0}\end{array}$

Chromium

0.29

0.30

0.30

$\cdots$

$\mathrm{S}$
$\mathrm{S}$
$\mathrm{S}$
$\mathrm{S}$
$\mathrm{S}$

$\cdots$

$\begin{array}{ll}\text { I-C3 } & \mathbf{0 . 5 8} \\ \text { I-C5 } & \mathbf{0 . 6 7} \\ \text { I-C7 } & \mathbf{0 . 6 8} \\ \text { I-C8 } & \mathbf{0 . 6 7} \\ \text { I-C10 } & \mathbf{0 . 5 8} \\ \text { I-C12 } & \mathbf{0 . 5 8} \\ \text { I-C14 } & \mathbf{0 . 8 3} \\ \text { I-C17 } & \mathbf{0 . 7 2} \\ \text { I-C18 } & \mathbf{0 . 7 5}\end{array}$

Copper

$16.53 \quad 25.67$

\begin{tabular}{|c|c|}
\hline ... & $\cdots$ \\
\hline-- & -.. \\
\hline$\cdots$ & $\cdots$ \\
\hline- & $\cdots$ \\
\hline & -.. \\
\hline & $\cdots$ \\
\hline & $\ldots$ \\
\hline
\end{tabular}

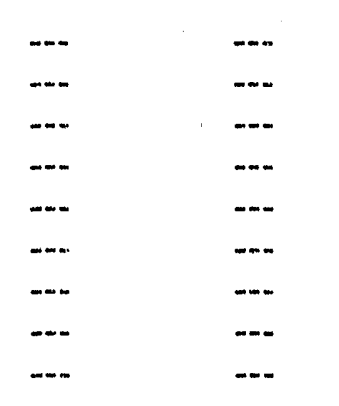

0.24

0.15

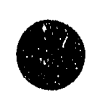

None are significantly different

Mercury

$$
\begin{array}{lll}
0.29 & 0.66 & 0.21
\end{array}
$$

0.15

$\begin{array}{cc}\ldots- & S \\ \ldots- & S \\ \cdots & S \\ \cdots & S \\ \cdots & S \\ \cdots & S \\ \cdots & S \\ -. & S\end{array}$

$\begin{array}{ll}\text { I-C17 } & \mathbf{0 . 2 7} \\ \text { I-S1 } & \mathbf{0 . 2 5} \\ \text { I-T1 } & \mathbf{0 . 3 8} \\ \text { I-T3 } & \mathbf{0 . 3 7}\end{array}$

Nickel

3.10

3.35

3.06

0.07

0.19

None are significantly different 
TABLE 3.46. (Contd)

Sediment Treatment and

Mean Tissue Concentration

(mg/kgdry weight)

$\frac{B-A C}{1.17} \frac{B-A M}{0.78} \frac{B-B E}{0.78} \frac{R-O S}{0.64} \frac{R-P C}{0.63} \frac{R-P F}{0.61}$

None are significantly different

Selenium
0.90
1.17
1.35
1.07
1.33
1.17

I-T1

1.99

S

Zinc

\section{$\begin{array}{llllll}191.67 & 188.80 & 192.40 & 198.77 & 193.97 & 184.53\end{array}$}

I-C11 262.00

I-C14

I-C17

I-C18

271.00

276.75

I-S 1

255.33

297.00

$\begin{array}{cc}-\cdots & \mathbf{S} \\ \mathbf{S} & \mathbf{S} \\ -\bar{S} & \mathbf{S} \\ \bar{S} & \mathbf{S}\end{array}$

\begin{tabular}{cc}
$\cdots$ & $\cdots$ \\
$\mathbf{S}$ & $-\cdots$ \\
\hdashline$-\bar{S}$ & $-\cdots$
\end{tabular}

$\begin{array}{r}--\bar{S} \\ \mathbf{S} \\ \hdashline \mathbf{S}\end{array}$

S

S

$S$

$S$

(a) Significant $(\alpha=0.1)$.
(b) Not significant $(\alpha=0.1)$. 
TABLE 3.47. Mean Butyltins Concentrations in Tissues of $N$. caecoides

Sediment

Treatment

I-C3

I-C5

I-C7

I-C8

1-C9

I-C10

I-C11

I-C12

I-C14

I-C15

I-C16

I-C17

I-C18

I-S1

I-T1

I-T3

R-AC

R-AM

R-BF

R-OS

R-PC

R-PF

C-SB

C-NE

C-NE-A (concentrations in $4 \mathrm{~g} / \mathrm{kg}$ dry weight)

\begin{tabular}{ccc}
\hline Tributyltin & Dibutyltin & Monobutyltin \\
\cline { 2 - 3 } & & \\
$89.12 \mathrm{UJ}(\mathrm{a})$ & $28.64 \mathrm{~J}(\mathrm{~b})$ & $23.37 \mathrm{~J}$ \\
$62.13 \mathrm{UJ}$ & $42.60 \mathrm{UJ}$ & $53.43 \mathrm{U}(\mathrm{c})$ \\
$95.25 \mathrm{UJ}$ & $33.24 \mathrm{UJ}$ & $48.29 \mathrm{UJ}$ \\
$92.49 \mathrm{~J}$ & $44.58 \mathrm{UJ}$ & $55.02 \mathrm{U}$ \\
$118.03 \mathrm{U}$ & $30.32 \mathrm{UJE}(\mathrm{d})$ & $25.17 \mathrm{JE}$ \\
119.96 & 48.63 & $56.08 \mathrm{U}$ \\
119.29 & $29.96 \mathrm{UJ}$ & 79.17 \\
90.35 & 34.38 & $36.95 \mathrm{UJ}$ \\
69.19 & $29.69 \mathrm{~J}$ & 27.46 \\
140.23 & 67.34 & 205.27 \\
73.80 & 59.23 & 95.38 \\
94.16 & $45.99 \mathrm{UJ}$ & $42.40 \mathrm{UJ}$ \\
104.33 & 62.70 & 215.38 \\
100.18 & $23.39 \mathrm{UJE}$ & $42.36 \mathrm{JE}$ \\
$120.00 \mathrm{U}$ & $23.41 \mathrm{UJ}$ & 40.21 \\
518.51 & 101.50 & $35.33 \mathrm{UJ}$ \\
45.03 & $42.13 \mathrm{UJ}$ & $48.65 \mathrm{UJ}$ \\
41.36 & $53.38 \mathrm{UJ}$ & $57.96 \mathrm{UJ}$ \\
56.50 & 57.79 & $51.76 \mathrm{UJ}$ \\
36.34 & $39.58 \mathrm{~J}$ & $67.36 \mathrm{U}$ \\
58.96 & 13.93 & 30.26 \\
32.04 & 32.92 & $26.49 \mathrm{~J}$ \\
$14.52 \mathrm{~J}$ & 48.89 & $39.65 \mathrm{UJ}$ \\
$68.01 \mathrm{UJ}$ & $68.37 \mathrm{UJ}$ & 53.04 \\
$40.92 \mathrm{UJ}$ & 41.00 & $34.86 \mathrm{UJ}$ \\
& &
\end{tabular}

(a) Undetected or detected below method detection limit (MDL) in all replicates; value is mean of dry weight detection limits and detected values.

(b) Analyte detected below method detection limits (MDL), but above instrument detection limits (IDL) in all replicates; value is mean of detected values.

(c) Undetected in all replicates; value is mean of dry weight detection limits.

(d) Mean includes one or more estimated values. 
TABLE 3.48. Butyltins in Tissues of N. caecoides That Are Significantly Different from Reference Tissue Concentrations Using Dunn's Test for Comparison of All Means Analysis (bold numbers are treatment mean concentrations in $\mu \mathrm{g} / \mathrm{kg}$ dry weight)

Sediment 'Treatment and Mean Tissue Concentration $\zeta$ L $/ \mathrm{kg}$ dry weight) $\frac{\mathrm{R}-A C}{45.03} \frac{\mathrm{B}-\mathrm{AM}}{41.36} \frac{\mathrm{R}-\mathrm{BF}}{56.50} \frac{\mathrm{B}-\mathrm{OS}}{\mathbf{3 6 . 3 4}} \frac{\mathrm{s}-\mathrm{PC}}{\mathbf{5 8 . 9 6}} \frac{\mathbf{3 2 . 0 4}}{\mathrm{R}-\mathrm{PE}}$

Tributylin

518.51

$S(a)$

S

$S$

$S$

$S \quad S$

Dibutulitin

\subsection{UJ 53.38 UJ 57.79}

$\begin{array}{llll}39.58 & J & 13.93 & 32.92\end{array}$

I-C 15

I-C16

I-C18

I-T3

67.34
59.23
62.70
101.50

-... (b)

$\cdots$

$\cdots$

$\begin{array}{lll}\cdots & \text { S } & \cdots \\ \cdots & S & \cdots \\ \cdots & S & \cdots\end{array}$

Monobutyltin

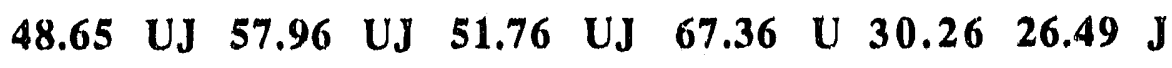

I-C15

$\begin{array}{ll}S & \cdots \\ S & \cdots\end{array}$

S

$\cdots$

S

S

(a) Significant $(\alpha=0.1)$,

(b) Not significant $(\alpha=0.1)$. 


\subsection{DISCUSSION AND CONCLUSIONS}

\subsection{GEOLOGY OF PROPOSED DREDGED SEDIMENTS}

The locations of core samples taken from areas proposed for dredging in Oakland Inner Harbor are presented in Figures 4.1 and 4.2. Figure 4.1 depicts all core siamples collected from Oakland Inner and Outer Harbors during the Phase III A sampling. All of the collected core samples were described by a geologist following the methodology described in Section 2.3.2. Sediment treatments from stations I-C1, I-C2, I-C6, and I-C13 were not included in biological or chemical analyses, thus no geologic descriptions are available. Four geologic cross sections were constructed in the Inner Harbor as a way of explaining the geology of the area. These cross sections, labeled A-A', B-B', C-C', and D-D' are depicted in Figure 4.2. Table 4.1 summarizes the geological descriptions for the Oakland Inner Harbor stations. Our discussion includes a general physical description of each transect, the quantity and physical description of the YBM and OBM present in the cross section to a maximum depth of $-44 \mathrm{ft}$, and a description of the material present in the -38 to $-44 \mathrm{ft}$ MLLW section. A summary of these observations is included in Table 4.1 .

Cross-section A comprises the center channel stations I-C8 through I-C12, I-C14, I-C15, and I-C18. This cross section extends from west (I-C8) to east (I-C18) and is defined in Figure 4.2 as $\mathrm{A}-\mathrm{A}^{\prime}$. The MLLW for this cross section range I from 35 to $38 \mathrm{ft}$. The thickness of the YBM unit in this cross section varied from 1 to $4.5 \mathrm{ft}$, and was composeil primarily of clayey silt. The Inner Oakland Harbor stations were composed primarily of OBM varying from 4 to $8 \mathrm{ft}$. The $\mathrm{OBM}$ was composed of sand at stations I-C8, I-C10, I-C11, and I-C12; silty clay at station I-C9; sandy silt at station I-C15; and a mixture of silt, sand, clay and gravel at stations I-C14 and I-C18.

Cross-section B comprises the stations I-T1, I-T3, and I-T5 (west to east), located on the south side of the waterway near Todd Shipyard. Figure 4.2 defines this cross section as B-B' (west to east). The MLLW water depths ranged from $-37 \mathrm{ft}$ to $-31 \mathrm{ft}$. The YBM unit varied in thickness from $7 \mathrm{ft}$ at Station I-T1 to $2 \mathrm{ft}$ at stations I-T3 and I-T5. The YKBM unit was composed of clayey silt at all three stations. The OBM unit was not present at Station I-T1, but was present for at least $11 \mathrm{ft}$ below the YBM unit at the other two stations. At Station I-T1, the -38 to $-44 \mathrm{ft}$ MLLW section was YBM composed of clayey silt, while at station I-T3 and I-T5, the -38 to $-44 \mathrm{ft}$ section was composed primarily of $\mathrm{OBM}$ exhibiting a colorful sand generally described as "Merritt Sand." 


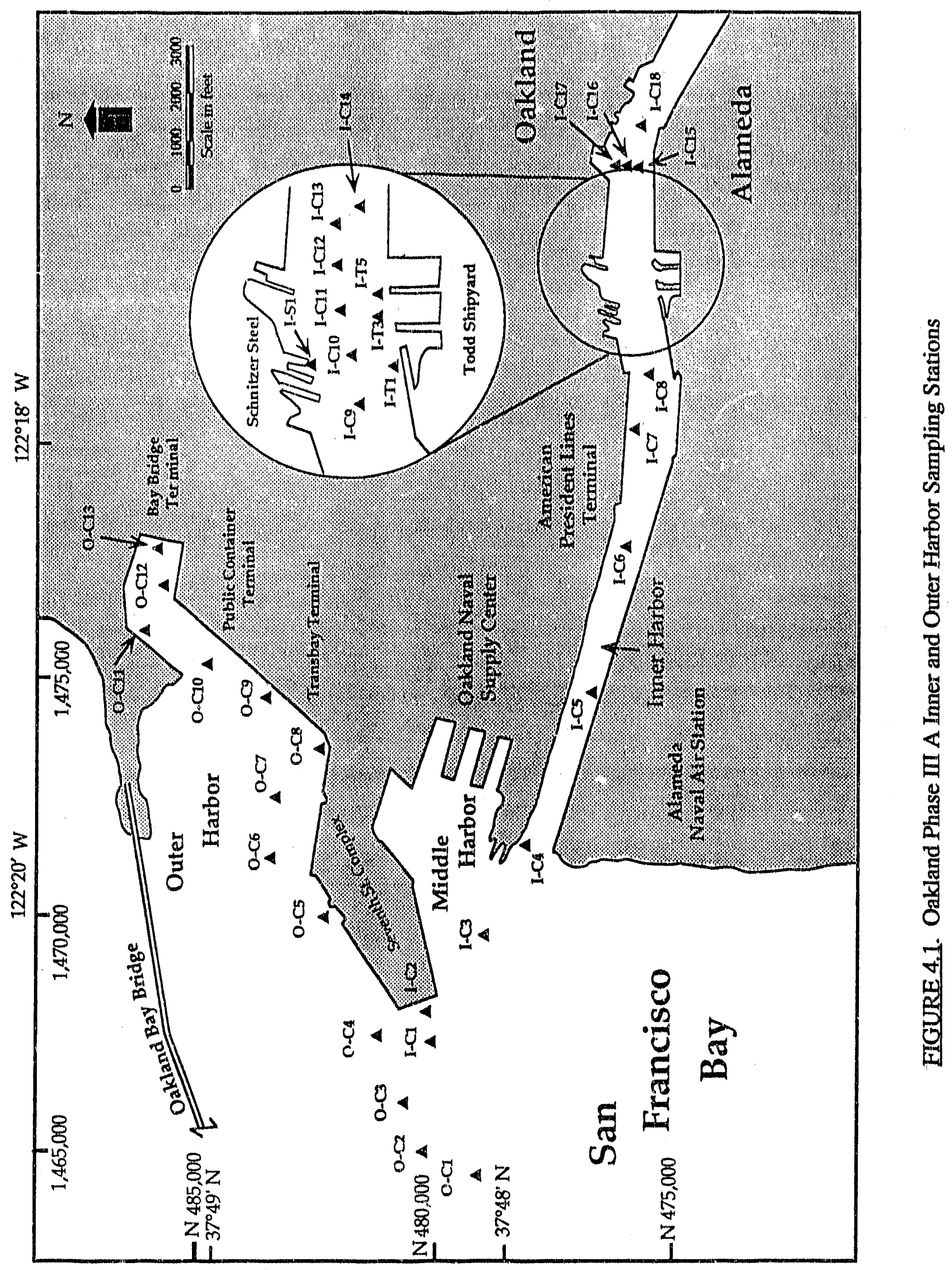

PHASEIIIA 


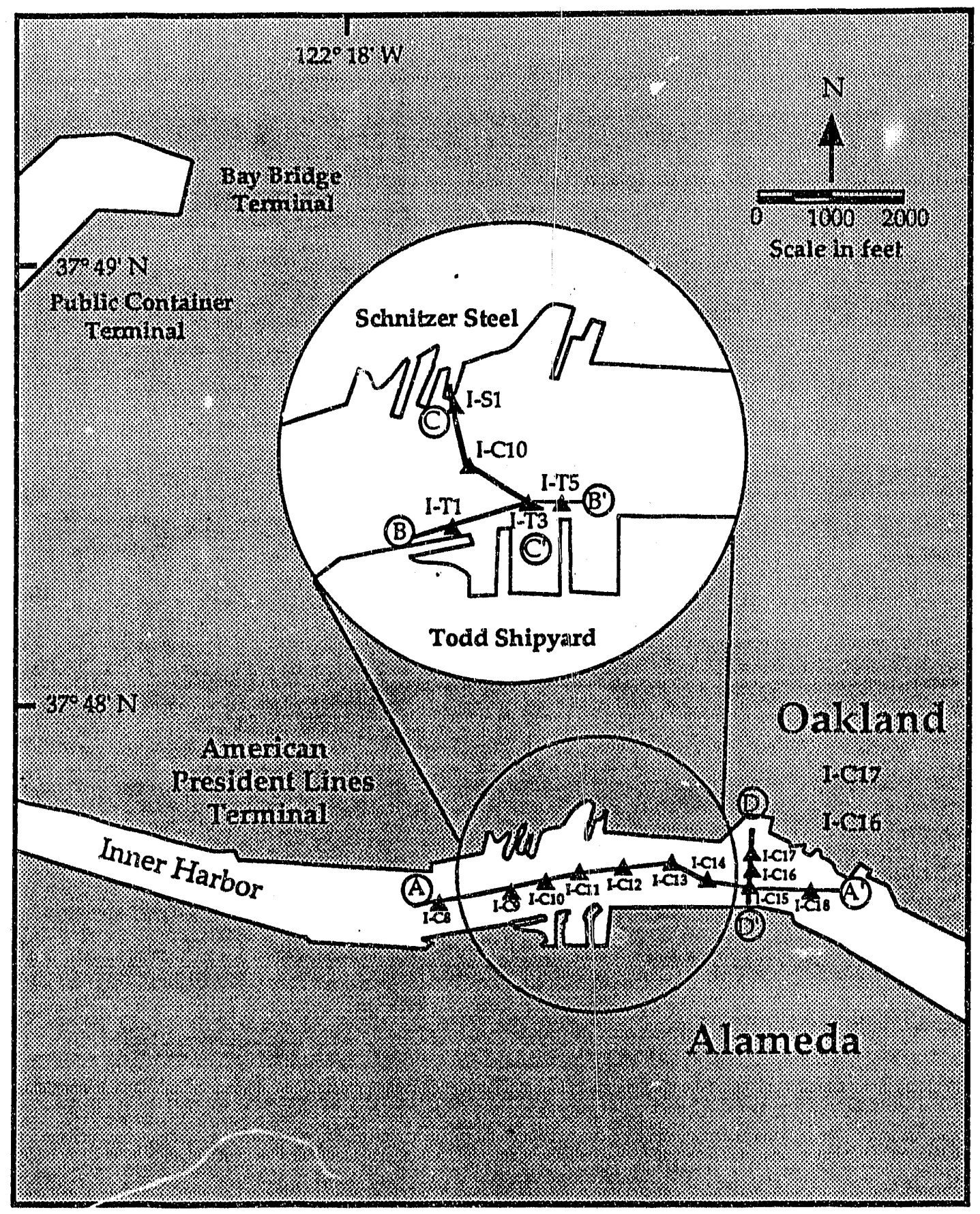

EIGURE 4.2. Oakland Inner Harbor Geological Cross Sections 
TABLE 4.1. Summary of Geologic Descriptions for Inner Oakland Harbor Stations

\begin{tabular}{|c|c|c|c|c|c|}
\hline \multirow[b]{2}{*}{$\begin{array}{l}\text { Station } \\
\text { I-C8 } \\
\text { I-C9 } \\
\text { I-C10 } \\
\text { I-C11 } \\
\text { I-C12 } \\
\text { I-C14 } \\
\text { I-C15 } \\
\text { I-C18 }\end{array}$} & \multirow[b]{2}{*}{$\begin{array}{l}\text { Transect } \\
\text { A } \\
\text { A } \\
\text { A } \\
\text { A } \\
\text { A } \\
\text { A } \\
\text { A } \\
\text { A }\end{array}$} & $\begin{array}{l}\text { MLLW } \\
\text { Depth (-ft) }\end{array}$ & \multicolumn{2}{|c|}{$\begin{array}{l}\text { Sediment } \\
\text { Thickness (ft)(a) } \\
\mathrm{YBM}^{(\mathrm{b})} \mathrm{OBM}^{(\mathrm{c})}\end{array}$} & \multirow[b]{2}{*}{$\begin{array}{l}\text { Physical Description } \\
\text { OBM - sand } \\
\text { Mostly OBM - silty clay } \\
\text { OBM - sand } \\
\text { Mostly OBM - sand } \\
\text { OBM - sand } \\
\text { OBM - mix of silt, sand, clay, gravel } \\
\text { OBM - sandy silt } \\
\text { Mostly OBM - clayey silt, some sand }\end{array}$} \\
\hline & & $\begin{array}{l}35.0 \\
35.0 \\
35.0 \\
37.0 \\
36.0 \\
35.0 \\
37.0 \\
38.0\end{array}$ & $\begin{array}{l}1.0 \\
4.5 \\
2.0 \\
2.0 \\
1.5 \\
2.0 \\
1.0 \\
2.0\end{array}$ & $\begin{array}{l}8.0 \\
4.5 \\
7.0 \\
5.0 \\
6.5 \\
7.0 \\
6.0 \\
4.0\end{array}$ & \\
\hline $\begin{array}{l}\text { I-T1 } \\
\text { I-T3 } \\
\text { I-T5 }\end{array}$ & $\begin{array}{l}\mathrm{B} \\
\mathrm{B} \\
\mathrm{B}\end{array}$ & $\begin{array}{l}37.0 \\
31.0 \\
31.0\end{array}$ & $\begin{array}{l}7.0 \\
2.0 \\
2.0\end{array}$ & $\begin{array}{r}0.0 \\
11.0 \\
11.0\end{array}$ & $\begin{array}{l}\text { YBM - clayey silt } \\
\text { OBM - sand } \\
O B M \text { - sand }\end{array}$ \\
\hline $\begin{array}{l}\text { I-S1 } \\
\text { I-C10 } \\
\text { I-T3 }\end{array}$ & $\begin{array}{l}\mathrm{C} \\
\mathrm{C} \\
\mathrm{C}\end{array}$ & $\begin{array}{l}32.0 \\
35.0 \\
31.5\end{array}$ & $\begin{array}{l}6.0 \\
2.0 \\
2.0\end{array}$ & $\begin{array}{r}6.0 \\
7.0 \\
10.5\end{array}$ & $\begin{array}{l}\text { OBM - silty clay } \\
\text { Mostly OBM - sand } \\
\text { OBM - sand }\end{array}$ \\
\hline $\begin{array}{l}\mathrm{I}-\mathrm{C} 17 \\
\mathrm{I}-\mathrm{C} 16 \\
\mathrm{I}-\mathrm{C} 15\end{array}$ & $\begin{array}{l}\text { D } \\
\text { D } \\
\text { D }\end{array}$ & $\begin{array}{l}36.5 \\
36.5 \\
37.0\end{array}$ & $\begin{array}{l}1.5 \\
1.0 \\
1.0\end{array}$ & $\begin{array}{l}6.0 \\
6.5 \\
6.0\end{array}$ & $\begin{array}{l}\text { OBM - sandy silt } \\
\text { OBM - clayey silt, sand, silty clay } \\
\text { OBM - sandy silt, clayey silt }\end{array}$ \\
\hline
\end{tabular}

(a) Thickness to $-44 \mathrm{ft}$ MLLW.

(b) Younger Bay Mud.

(c) Older Bay Mud.

Cross-section C comprises the stations I-S1, I-C10, and I-T3. This cross section extends across the waterway from the Alameda side to the Oakland side of the proposed turning basin. The cross section is defined in Figure 4.2 as C-C. The water depths varied from -31.5 to $-35 \mathrm{ft}$ MLLW. The YBM unit varied in! thickness across this transect from $6 \mathrm{ft}$ to $2 \mathrm{ft}$ (northwest to southeast) and was composed of clayey silt. The OBM unit underlying the YBM varied in thickness from at least 6 to $10.5 \mathrm{ft}$. The -38- to $-44-\mathrm{ft}$ portion of all three stations was composed of OBM. The OBM unit at Station I-S1 was silty clay, while the OBM unit at stations I-C10 and I-T3 was Merritt Sand.

Cross-section D comprises the stations I-C17, I-C16, and I-C15, extending north to south across Oakland Inner Harbor near the proposed turning basin area. This cross section is defined as D-D' in Figure 4.2. Water depths were nearly identical at the three stations $(-36.5$ to $-37.0 \mathrm{ft}$ MLLW). The YBM unit varied in thickness from 1 to $1.5 \mathrm{ft}$, and was composed of clayey silt. 
silt. The OBM thickness ranged from 6 to $6.5 \mathrm{ft}$ below the YBM unit. The -38 to $-44 \mathrm{ft}$ MLLW portion of this cross section was primarily OBM composed of sandy silt at Station I-C17, and a mixture of clayey silt, sandy silt, sand, and silty clay at stations I-C16 and I-C15.

\subsection{SEDIMENT CHEMISTRY}

According to the Draft Implementation Manual, sediment chemistry results are intended to provide information about chemicals that could potentially cause toxicity or be bioaccumulated. These results are not intended to evaluate the suitability of sediments for open-ucean disposal, but should be used to validate the assumptions that these areas show signs of potential effects. Sediment chemistry results used in conjunction with toxicity tests and bioaccumulation results will aid in the evaluation of appropriate disposal options. Sediments from the Phase III A and Phase III A retest were evaluated for conventionaì measurements, metals, and organic measurements. Conventional chemistry measurements were determined from grain size, TVS, TOC, oil and grease, and TPH. Organic measurernents included PAHs, PCBs, chlorinated pesticides, and butyltins.

The Phase III A sediment treatments I-C5, I-C9, I-S1, and I-T1 had the highest levels of conventionals and metals. Reference treatments R-BF and R-OS and control sediment C-SB were among the top ten stations with higher levels of conventionals and metals. Most of the PCBs and pesticides were undetected at the detection limit. Sediment treatments I-C5, I-S1, and I-T1, had the highest levels of organics. This follows the same general trend as the conventional and metals parameters. Sediment treatments I-T1, I-T5, and I-T3 had the highest concentrations of butyltins in the sediment.

The Phase III A retest sediments followed the same trend as the Phase III sediments that were measured. The sediment containing fine grain sizes (sand and silt) had higher TOC, TVS, oil and grease, and TPH levels. Sediment treatments I-C5, I-C9, I-S1, I-T1, R-AC, R-OS, and C-SB had the highest levels of TOC and TVS. Oil and grease and TPH followed similar trends with I-C5, I-S1, I-T1, and R-AC having the highest levels. All sediment treatments were analyzed for the same ten metals as the Phase III A sediments. Treatments I-S1 and I-T1 contained the highest levels for six of the ten metals, with the exception of $\mathrm{As}, \mathrm{Cd}, \mathrm{Cr}$, and Se. Reference and control sediments R-AC, R-BF, R-OS, and C-SB were among the hichest for conventional and metals concentrations. Sediment treatment I-T3 was highest in levels of butyltins and PCB Aroclor 1254. Treatments I-S1, I-T1, and R-AC had the highest levels of PAHs. Reference and control sediments R-AC, R-BF, and C-SB were among the highest concentrations of organics measured. 


\subsection{TOXICOLOGYAND BIOACCUMULATION}

Toxicology and bioaccumulation results are used in the characterization of test sediment treatments from areas proposed for dredging. For each of the six reference treatments, we have determined the test treatments that produced significant acute toxicity or bioaccumulation potential relative to reference. For the purposes of this discussion, "significant" acute toxicity means that the solid phase test material does not comply with the benthic bioassay criteria for ocean disposal [CFR40, Section 227.13 (c)]. A summary of these comparisons is presented in Table 4.2; comparison to individual reference sediments is shown in each section. The results of the SPP tests have not been included in these tables because acute toxicity was observed only in the C. gigas test for the sediment composite BC-4 (LC50 of 91.9\% SPP). By examining the results of the toxicity and bioaccumulation evaluations of test treatments compared to each reference, USACE will be able to assess disposal options for Oakland Inner Harbor dredged material.

Though the results of these comparisons varied depending on the choice of reference site, a number of observations were consistent between reference comparisons. First, acute toxicity was noted in only two of the 10-day solid-phase tests: the static $R$. abronius test and the $N$. caecoides retest. The initial 10-day $N$. caecoides test and the 10-day $R$. abronius flow-through with air and without air tests will not be included in this discussion, as they are not considered standard tests. Second, significant levels of PAHs occurred most often in the tissues of N. caecoides relative to reference, and were composed primarily of LPAH compounds, the dominant LPAH being naphthalene. Significantly elevated levels of PAHs in the tissues of $M$. nasuta were usually HPAH compounds. Finally, elevated levels of metals in the tissues of $M$. nasuta were due primarily to the presence of $\mathrm{Cr}$ and $\mathrm{Ni}$, while $\mathrm{Cr}, \mathrm{Cd}$, and $\mathrm{Zn}$ were most of ten elevated in the tissues of $N$. caecoides. What follows is a discussion of toxicological and bioaccumulation trends in test treatments relative to each of the six references.

TABLE 4.2. Summary of Toxicological and Bioaccumulation Hits for Each Reference

Reference

Treatment

R-AC

R-AM

R-BF

$\mathrm{R}-\mathrm{OS}$

R-PC

R-PF

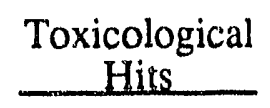

4

11

4

4

12

\section{$\frac{\text { Bioaccumulation Hits }}{M . \text { nosuta }} \frac{N \text { caecoides }}{N \text {. }}$}

26

16

28

25

41

39
Total 32 62 41 44 71 54 


\subsubsection{Comparison of Test Treatments to the Reference Sediment R-AC}

Table 4.3 summarizes the results of acute toxicity and bioaccumulation tests for each test treatment relative to the reference R-AC (Alcatraz Island Disposal Site). This table shows that significant acute toxicity was observed in four test treatments: I-C9, I-C16, I-C17, and I-C18. Two instances of significantly elevated levels of contaminants were noted in the tissues of $M$. nasuta. N. caecoides tissues showed elevated levels of LPAH (primarily naphthalene) in all but four treatments, elevated levels of the PCB Aroclor 1254 in one treatrnent (I-T3), elevated levels of butyltins in three treatments (I-C15, I-C18, and I-T3), and elevated levels of metals in five treatments (I-C14, I-C17, I-C18, I-S1, and I-T1). A total of 32 toxicological or bioaccumulation hits were observed in test treatments relative to R-AC, where a hit is defined by the following criteria: 1) as a significant decrease in test organism survival and statistically different relative to reference or, 2) an elevated level of LPAH, HPAH, PCB, a butyltin, or any of the ten measured metals relative to reference. The 32 hits observed relative to $\mathrm{R}-\mathrm{AC}$ was the lowest total of the six references compared in this study.

\subsubsection{Comparison of Test Treatments to the Reference Sediment R-AM}

Table 4.4 summarizes the results of acute toxicity and bioaccumulation tests for each test treatment relative to the reference R-AM (Alcatraz Island Environs). Acute toxicity was observed in eight test treatments, including I-C8, I-C9, I-C14, I-C15, I-C16, I-C17, I-C18, I-T1, and I-T3. The $M$. nasuta bioaccumulation exposures showed significantly elevated HPAHs in six test treatments, including I-C10, I-C15, I-S1, I-T1, I-T3, and I-T5. Tributyltin was elevated in test treatments I-T3 and I-T5. Chromium was significantly elevated in $M$. nasuta tissues exposed to all the test treatments. In the $N$. caecoides bioaccumulation exposures, PAHs were elevated in nine test treatments, the PCB Aroclor 1254 and tributyltin were elevated only in test treatment I-T3, and the metal $\mathrm{Zn}$ was elevated in test treatments $\mathrm{I}-\mathrm{C} 11, \mathrm{I}-\mathrm{C1} 14, \mathrm{I}-\mathrm{C1} 1$, and I-S1. Significant acute toxicity or evidence of bioaccumulation potential occurred in all test treatments. Comparison of test treatment acute toxicity and bioaccumulation results to the reference R-AM produced 62 hits, the second highest total of the six references.

\subsubsection{Comparison of Test Treatments to the Reference Sediment R-BF}

Table 4.5 summarizes the results of acute toxicity and bioaccumulation tests for each test treatment relative to the reference R-BF (Bay Farm Borrow Area). This table shows that significant acute toxicity was observed in four test treatments: I-C15, I-C16, I-C17, and I-C18. Bioaccumulation tests involving $M$. nasuta showed elevated HPAH in tissues exposed to test treatments I-C10, I-C15, I-S1, I-T1, I-T3, and I-T5. Tributyltin was elevated only in test 


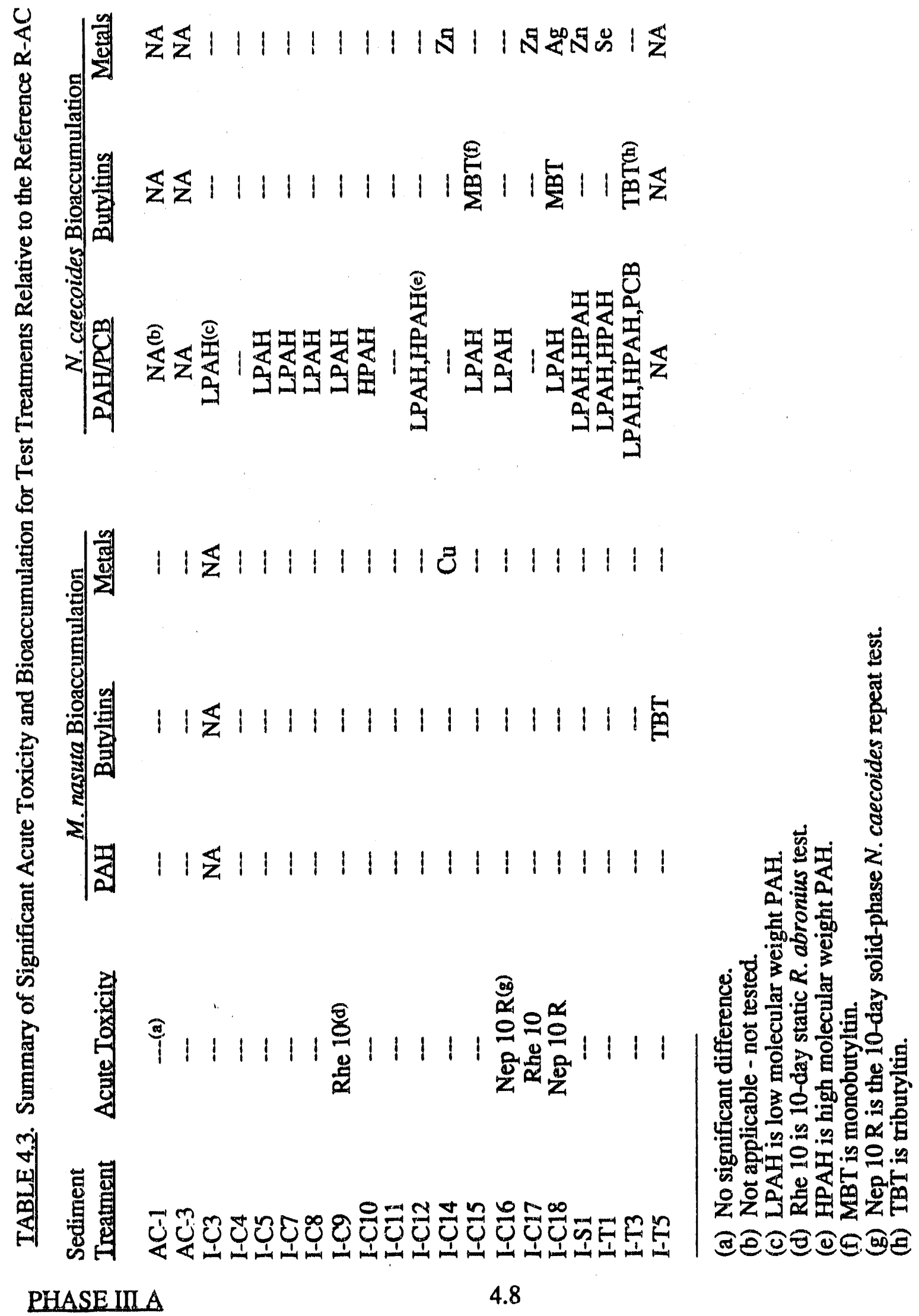




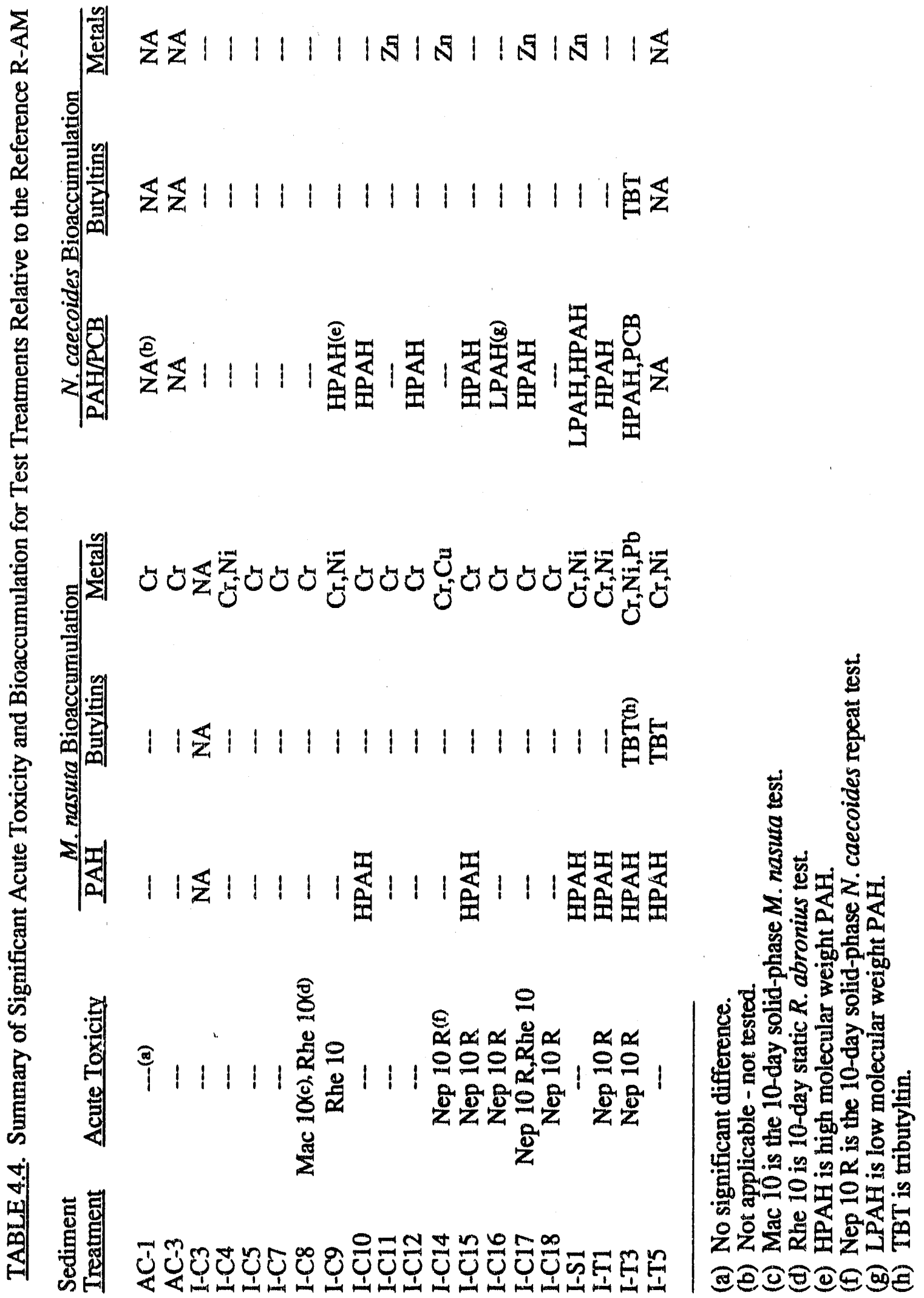




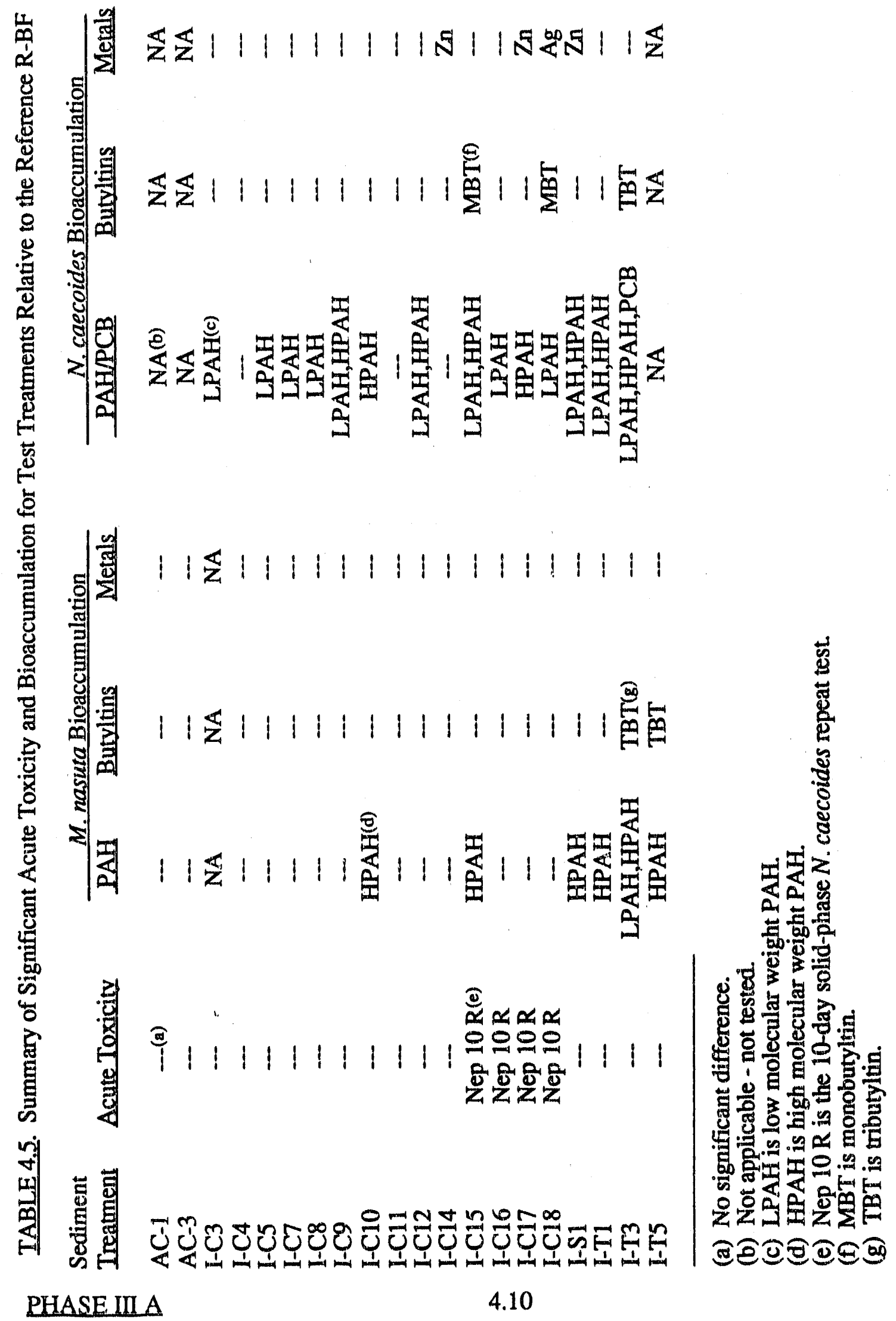


treatments I-T3 and I-T5. There was no evidence of elevated metals in M, nasuta tissues in test treatments relative to R-BF. In the $N$. caecoides exposures, elevated PAHs were observed in all but three of the test treatments, and elevated PCB (Aroclor 1254) occurred in test treatment I-T3. Monobutyltin was elevated in test treatments I-C15 and I-C18; elevated tributyltin occurred in treatment I-T3. Elevated levels of $\mathrm{Zn}$ occurred in test treatments I-C14, I-C17, and I-S1; elevated levels of $\mathrm{Ag}$ occurred in test treatment I-C18. Two treatments, I-C4 and I-C11, produced no acute toxicity or evidence of bioaccumulation potential. Comparison of toxicological and bioaccumulation data from test treatments to the reference R-BF yielded 41 hits, the second lowest total of the six references.

\subsubsection{Comparison of Test Treatments to the Reference Sediment R-OS}

Table 4.6 presents the results of acute toxicity and bioaccumulation in test treatments relative to the reference treatment R-OS (Deep Off-Shelf). The data presented in this table show acute toxicity occurred in test treatments $\mathrm{I}-\mathrm{C} 15, \mathrm{I}-\mathrm{C} 16, \mathrm{I}-\mathrm{C} 17$, and $\mathrm{I}-\mathrm{C} 18$. Examination of $M$. nasuta bioaccumulation results show elevated levels of $\mathrm{HPAH}$ in test treatments I-C10, I-C.15, I-C18, I-S1, I-T1, I-T3, and I-T5. Butyltins were elevated in M. nasuta tissues exposed to test treatments I-T3 and I-T5; metals were elevated in test treatments AC-1, I-C14, I-C16, I-T1, and I-T3. The results of the $N$. caecoides bioaccumulation tests show elevated levels of LPAH in all but five test treatments, and elevated levels of PCB Aroclor 1254 and tributyltin (TBT) in test treatment I-T3. Elevated levels of Zn occurred in test treatments I-C17 and I-S1; elevated levels of Ag occurred in test treatment I-C18. Test treatments I-C4 and I-C11 produced no acute toxicity or evidence of bioaccumulation potential. Comparison of toxicological and bioaccumulation results to the reference treatment R-OS produced 44 hits, the third lowest total of the six references.

\subsubsection{Comparison of Test Treatments to the Reference Sediment R-PC}

Table 4.7 summarizes the results of acute toxicity and bioaccumulation exposures of test treatments relative to the reference R-PC (Point Reyes Coarse). This table shows that ten test treatments produced significant acute toxicity, including I-C8, I-C9, I-C11, I-C14, I-C15, I-C16, I-C17, I-C18, I-T1, and I-T3. Bioaccumulation results for $M$. nasuta produced elevated levels of HPAH in seven test treatments (I-C10, I-C15, I-C18, I-S1, I-T1, I-T3, and I-T5), and elevated levels of butyltins in three treatments (I-T1, I-T3, and I-T5). Metals were elevated in five treatments including AC-1, AC-3, I-C9, I-C14, and I-T3. The metals $\mathrm{Ag}, \mathrm{Cu}, \mathrm{Ni}$, and $\mathrm{Pb}$ accounted for the elevated levels. Examination of $N$. caeccides bioaccumulation data shows elevated levels of PAH (primarily LPAH) in all test treatments except I-C4, I-C11, and I-C14. 


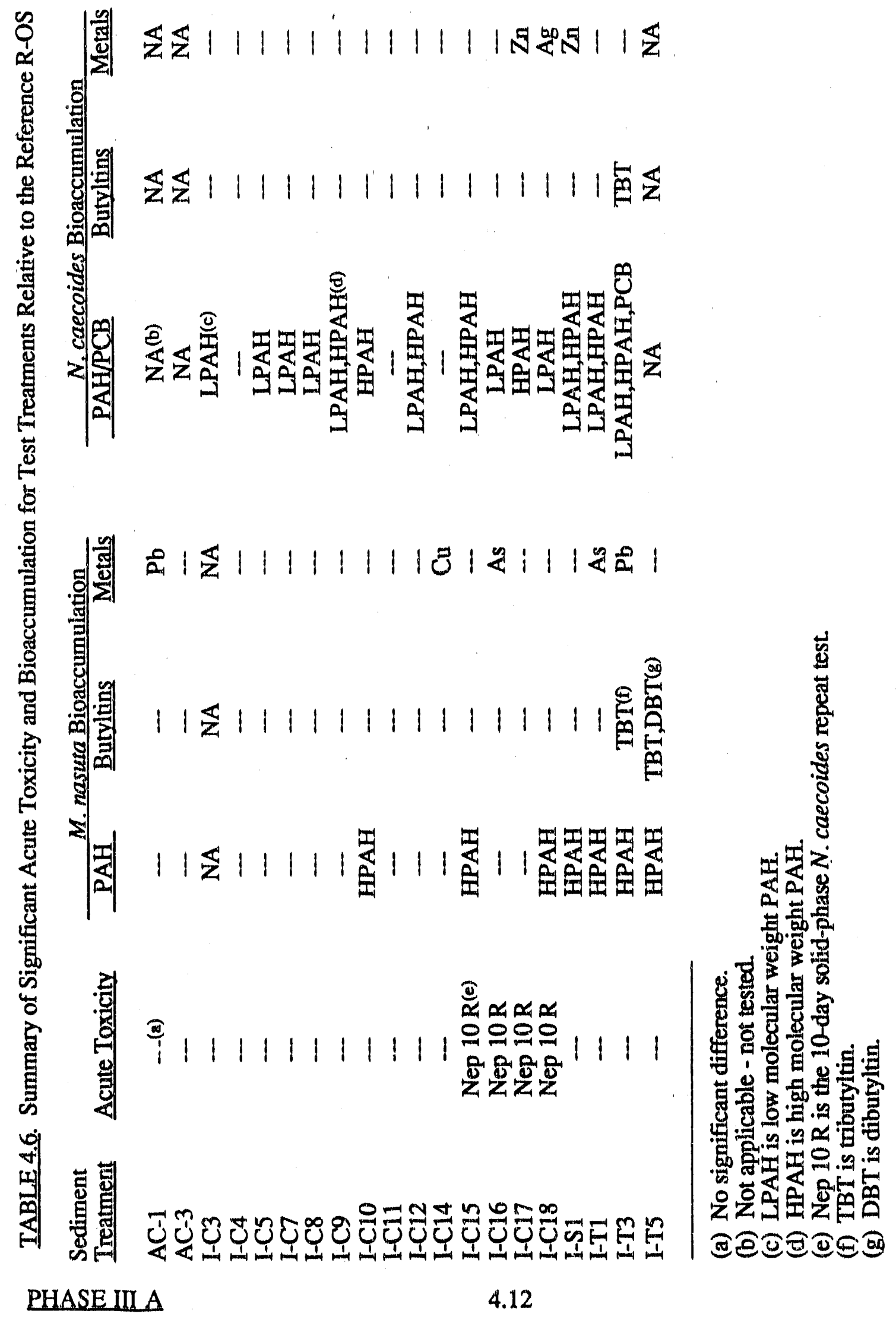




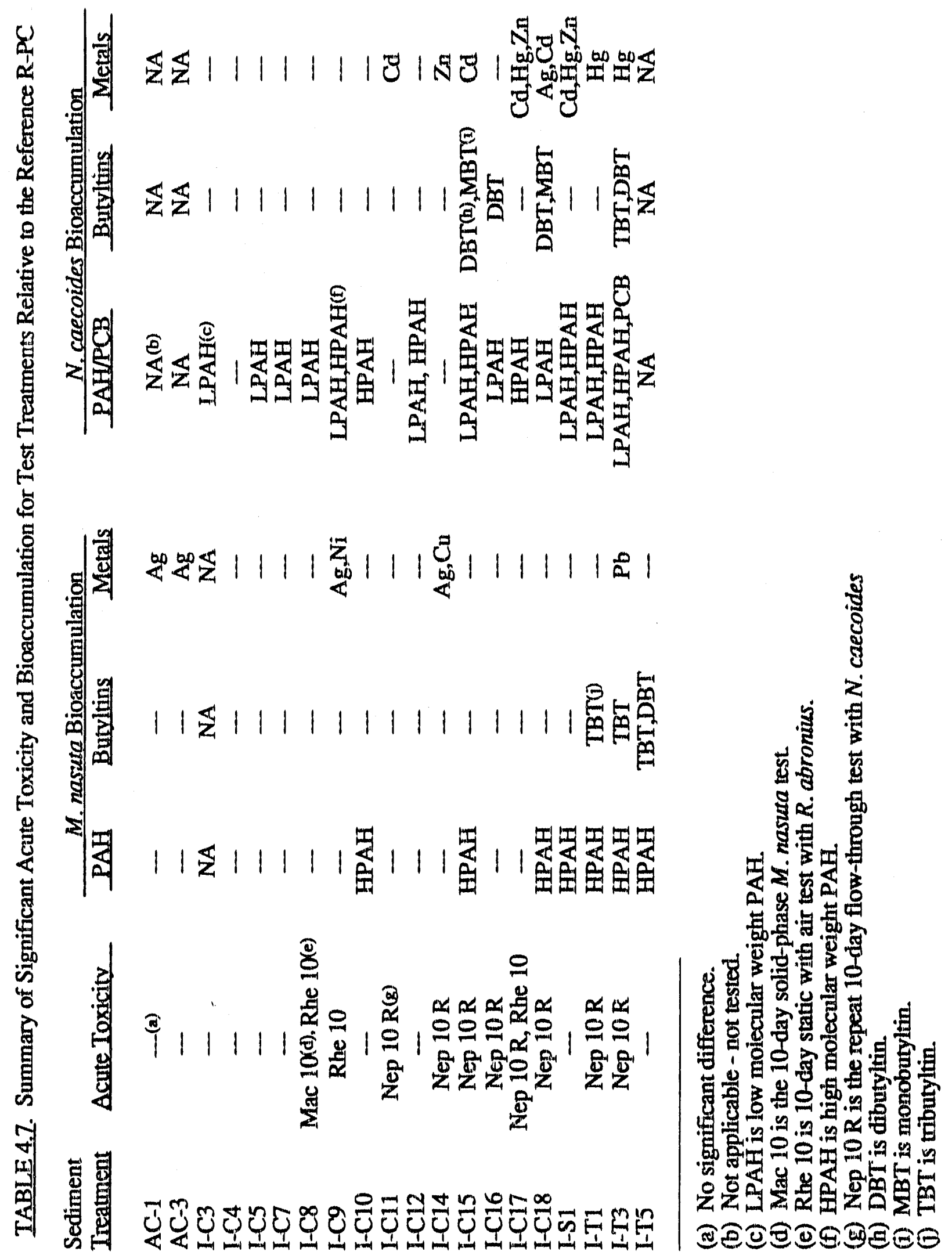
PHASEIIIA 4.13 
Butyltins were elevated in four test treatments (I-C15, I-C16, I-C18, and I-T3); metals were elevated in eight treatments. The metals cadmium, zinc, mercury, and silver accounted for the elevated levels. One test treatment, I-C4, produced no acute toxicity or evidence of bioaccumulation potential. Comparison of toxicological and bioaccumulation results in test treatments to the reference R-PC produced 71 toxicological hits, the highest total of the six references.

\subsubsection{Comparison of T'egt "Creatments to the Reference Sediment R-PE}

Table 4.8 presents the results of toxicological and bioaccurnulation tests of the test treatments relative to the reference R.PF (Point Reyes Fine). This table shows significant acute toxicity occurred in test treatments I-C8, I-C15, 1-C16, I-C17, and I-C18. Examination of $M$. nasuta bloaccumulition results indicates the elevated PAH levels in tissues occurred in test treatments I-C10, I-C15, I-C18, I-S1, I-T1, I-T3, and I-TS. These elevations were composed of HPAH. Elevated levels of butyltins occurred in two treatments (I-T3 and I-T5), and there was no evidence of elevated levels of metals associated with the tissues of $M$. nasuta exposed to test treatments. $N$. caecoides bioaccumulation results show elevated levels of PAH in all test treatments except I-C4, I-C11, and I-C14. Butyltins were elevated only in tost treatments I-C15, I-C18, and I-T3. Metals were elevated in all test treatments except I-C4, I-C9, I-C15, I-C16, I-T1, and 1-T3. The elevated metals were due to the prosence of $\mathrm{Cr}, \mathrm{Zn}$, and $\mathrm{Ag}$. Test treatment I-C4 produced no acute toxicity or evidence of bioaccumulation potential. Comparison of toxicological and bioaccumulation results in test treatments relative to the reference R-PFi produced 54 hits, the third highest total observed in the six references.

\subsection{CONCLUSIONS}

The tiered approach to evaluating the potential impacts of ocean disposal of dredged material is presented in the Draft Implementation Manual (See Figure 3.1). This approach consists of a series of activities (tests) and decision modules (determination of compliance) to guide the evaluation of dredged sediment. The work presented in this report on Oakland Harbor Phase III A testing falls under the Tier III guidelines and consists of water column toxicity testing, deposited sediment (solid phase) toxicity testing, and examination of the potential for bioaccumulation of contaminants associated with the deposited sediments. Physical and chemical. analyses of materials proposed for dredging are used in this study only to verify sediment grain size and to help explain toxicological and bioaccumulation results. The following discussion summarizes the tests conducted by MSL under Tier III using the determination of compliance definitions provided by the Draft Implementation Maruual. 


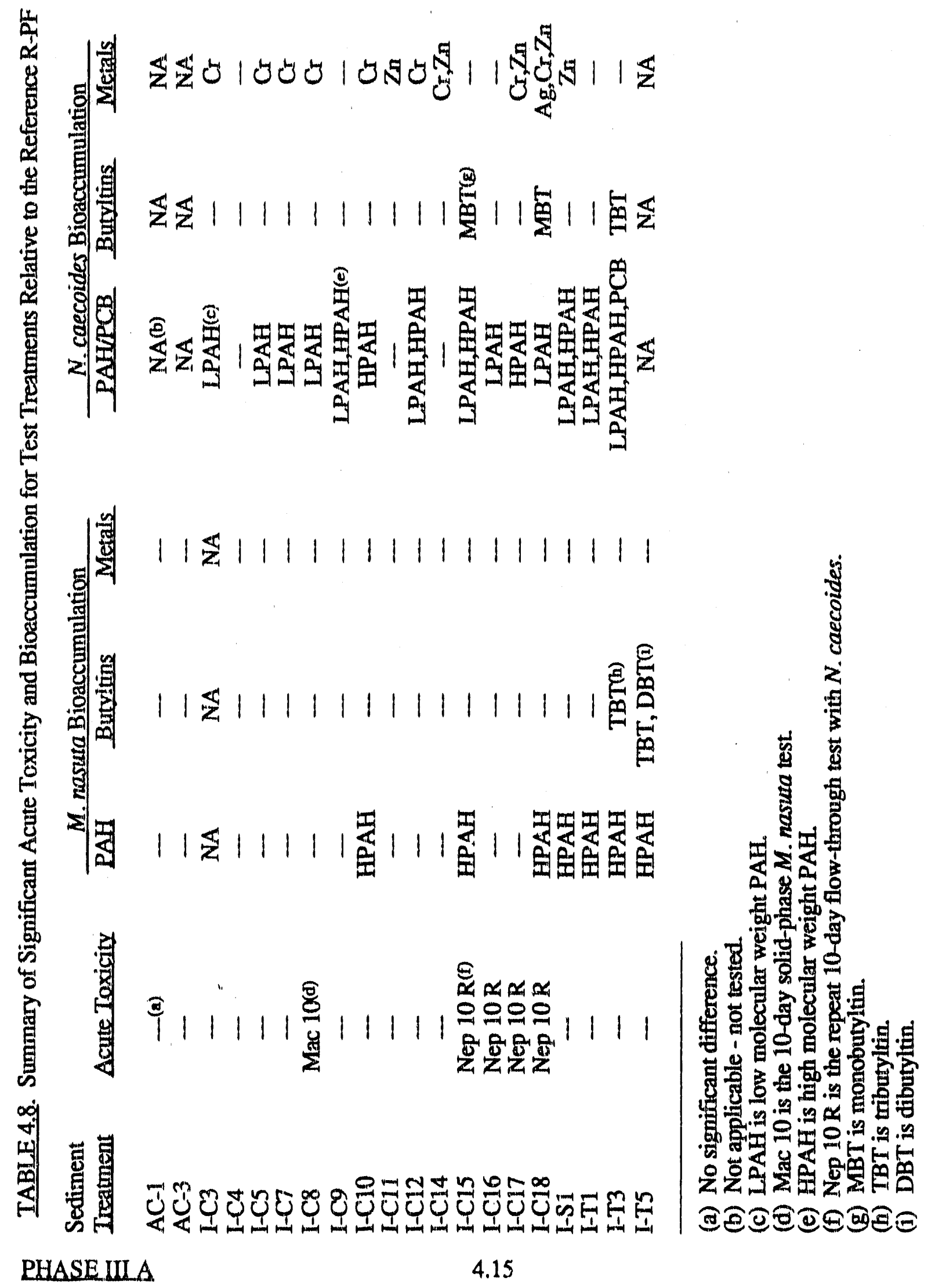




\subsubsection{Water Column}

Estimates of toxicity in the water column associated with the dumping of dredged material were evaluated by exposing three sensitive murine species (H. sculpta, C. stigmaeus, and $C$. gigas) to the SPP of two sediment composites, $\mathrm{BC}-3$ and $\mathrm{BC}-4$. Composite $\mathrm{BC}-3$ was composed of Oakland Inner Harbor stations I-C14, I-C15, I-C16, I-C17, and I.C18. Composite BC-4 was composed of Oakland Inner Harbor stations I-C9, I-C10, I-C11, and I-C12. Four concentrations of SPP were tested: $0 \%$ (seawater), $10 \%, 50 \%$, and $100 \%$. Determination of compliance for this test involves deciding whether the concentration of dissolved plus suspended contaminants, after allowance for initial mixing, is greater than 0.01 of the acutely toxic concentration beyond the boundaries of the disposal site within the first $4 \mathrm{~h}$ after disposal. The SPP tests of the two Oakland Inner Harbor composites showed no acute toxicity for composite BC-3, and an estimated LC50 of 91.9\% SPP for composite BC-4 using the 4-day C. gigas test. Using the determination of compliance criteria, the concentration of dissolved plus suspended contaminants would have to be less than $0.92 \%$ to ensure that this criteria was not violated.

\subsubsection{Deposited Sediment Toxicity.}

Deposited sediment toxicity was determined by exposing four species of marine organisms ( $M$. nasuta, $N$. caecoides, $C$. stigmaeus, and $R$. abronius) to test sediment treatments in a series of solid-phase tests. Tier III guidelines concerning determination of compliance for deposited sediment toxicity evaluate whether the mortality in test treatments exceeds the reference treatment by $20 \%$ ( $R$. abronius) or $10 \%$ (other species). If the mortality of the test organisms in test treatments is significantly different than the reference mortality and exceeds the reference mortality by the above percentages, the test materials are not in compliance with the benthic bioassay criteria of $40 \mathrm{CFR}$, Section 227.13 (c). The data presented in Tables 4.5 through 4.8 show that there was no observed toxicity in 11 test treatments; AC-1, AC-3, I-C3, I-C4, I-C.5, I-C7, I-C10, I-C12, I-S1, and I-T5. The strongest evidence of acute toxicity was associated with sediment treatments $\mathrm{I}-\mathrm{C} 15, \mathrm{I}-\mathrm{C} 16, \mathrm{I}-\mathrm{C} 17$, and $\mathrm{I}-\mathrm{C} 18$ in both the $N$. caecoides and $R$, abronius solid-phase tests. In treatments I-C16, 1-C17, and I-C18, acute toxicity was observed relative to all six references. For treatment I-C15, acute toxicity was observed relative to five of the six references. In the remaining test treatments, toxicological hits were scattered relative to the six references.

\subsubsection{Bioaccumulation}

The potential for bioaccumulation of contaminants was evaluated through 28-day solid-phase flow-through tests of $M$. naiuta and $N$. caecoides. The concentrations of contaminants were compared to existing Food and Drug Administration limits, and were also compared using 
Dunn's Test to determine whether statistically significant levels of contaminants were present relative to the reference $(\alpha=0.10)$. Bioaccumulation results showed that statistically significant levels of contaminants were associated with the tissues of $M$. nasuta and $N$. caecoides in all test sediment treatments when compared to the reference. The fewest incidences of elevated levels were associated with test treatments I-C4 and I-C1 1 ; the most were associated with I-S1, I-T1, and I-T3. General comparison of test treatments to the six references showed the most incidences of elevated tissue-associated contaminants when test treatments were compared to the reference R-PC (Point Reyes Coarse). The fewest incidences occurred in comparison to R-AC (Alcatraz Island Disposal Site). The significance of these comparisons depends on the reference to which the test treatments are compared. According to the Draft Implementation Manual, further evaluation of the test sediments and the potential dredged material they represent may be necessary to determine whether these materials can be disposed of in the ocean. These evaluations may take the form of numerical modeling, case-specific testing, or other management action as defined by the Draft Implementation Manual and developed by the USACE District Engineer and EPA Regional Administrator. The summary results presented in Tables 4.3 through 4.8 should aid in this decision and policy-making. 


\subsection{REEERENCES}

American Society for Testing and Materials (ASTM). 1972. Standand Method for Particle-Size Analysis of Soils (with the substitution of the No 100 sieve for the No. 140 sieve). D422. American Society for Testing and Materials, Philadelphia, Pennsylvania.

American Society for Testing and Materials (ASTM). 1978. Standard Method for Dry Preparation of Soil Samples for Particle-Size Aualysis and Determination of Soil Constants. D421. American Society for Testing and Materials, Philadelphia, Pennsylvania.

American Society for Testing and Materials (ASTM). 1984. Standard Practice for Descriotion and Identification of Soils. D2488-84. American Society for Testing and Materials, Philadelphia, Pennsylvania, pp. 293-302.

American Society for Testing and Materials (ASTM). 1989. Standard Practice for Description and Identification of Soils (Visual-Manual Procedures). D2488-84. Annual Book of ASTM Standards, Philadelphia, Pennsylvania, Section 4, pp. 298-307.

Barry, R. G. 1983. Late-Pleistocene Climatology: Late Quaternary Environments of the United States. University of Minnesota Press, Minneapolis.

Bloom, N. S., and E. A. Crecelius. 1983. "Determination of Mercury in Seawater at SubNanogram per Liter Levels." Marine Chemistry 14:49-59.

Bloom, N. S., and E. A. Crecelius. 1984. "Distribution of Silver, Mercury, Lead, Copper and Cadmium in Central Puget Sound Sediments." Marine Chemistry 21:377-390.

Climate, Long-Range Investigation, Mapping, and Prediction Project (CLIMAP). 1984. The Last Interglacial Ocean: Quat. Re. 21:123-224.

Dunn, O. J. 1961. "Multiple Comparisons Among Means." Journal of the American Statistical Association. Vol. 56, pp. 52-64.

Dupuy, J. I., N. T. Windsor, and C. E. Sutton. 1977. Manual for Design and Qperation of an Oyster Seed Hatchery, Special Report No. 142 in Applied Marine Science and Ocean Engineering, Virginia Institute of Marine Science, Gloucester Point, Virginia.

EPA. See U.S. Environmental Protection Agency.

Kohn, N. P., J. A. Ward, H. L. Mayhew, J. Q. Word, E. S. Barrows, S. M. Goodwin, and L. F. Lefkovitz. 1992. Ecological Evaluation of Proposed Discharge of Dredged Material Erom Qakland Harbor into Qcean Waters (Phase III B of -42-Foot Project). PNL-8174, Pacific Northwest Laboratory, Richland, Washington.

Finney, D. J. 1971. Probit Analysis. Third ed., Cambridge University Press. Cambridge.

Krauskopf, K. 1967. Introduction to Geochemistry. McGraw-Hill International Series in the Earth and Planetary Sciences, McGraw-Hill, New York. 
Mayhew, H. L., N. P. Kohn, J. A. Ward, J. Q. Word, and M. R. Pinza. 1992. Ecological Evaluation of Oakland Harbor Phase III -38-Foot Composites Relative to the Alcatraz Island Environs (R-AM). PNL-7963, Pacific Northwest Laboratory, Richland, Washington.

Puget Sound Estuary Program (PSEP). 1986. Recommended Protocols for Measuring Selected Environmental Variables in Puget Sound. Volumes 1 and 2. Prepared by Tetra Tech, Inc. for the Puget Sound Estuary Program, Bellevue, Washington.

Unger, M. A., W. G. MacIntyre, J. Greaves, and R. J. Huggett. 1986. "GC Determination of Butyltins in Natural Waters by Flame Photometric Detection of Hexyl Derivatives with Mass Spectrometric Confirmation." Chemosphere 15(4):461-470.

U.S. Army Corps of Engineers (USACE). 1975. Dredge Disposal Stlidy: San Francisce Bay and Estuary. U. S. Army Corps of Engineers, San Francisco District.

U.S. Environmental Protection Agency (EPA). 1979. Test Methods for Evaluating Solid Waste: Physical/Chemical Methods. EPA-600 4-79-020 Methods 413.2, 418.1. Environmental Monitoring and Support Laboratory, Cincinnati, Ohio.

U.S. Environmental Protection Agency (EPA). 1986a. Reconnaissance Survey of Eight Bays in Pugel Sound. U.S. Environmental Protection Agency, Region 10.

U.S. Environmental Protection Agency (EPA). 1986b. Test Methods for Evaluating Solid Waste: Physical/Chemical Methods. EPA-955-001-00000. U.S. Environmental Protection Agency, Government Printing Office, Washington, DC.

U.S. Environmental Protection Agency/Corps of Engineers Technical Committee on Criteria for Dredged and Fill Material (EPA/USACE). 1977. Ecological Evaluation of Proposed Discharge of Dredged Material into Ocean Waters: Implementation Manual for Setion 103 of Public Law 92 532 (Marine Protection. Research. and Sanctuaries Act of 1972). Environmental Effects Laboratory, U.S. Army Engineer Waterways Experiment Station, Vicksburg, Mississippi.

U.S. Environmental Protection Agency/U.S. Army Corps of Engineers (EPA/USACE). 1990. Draft Ecological Evaluation of Proposed Discharge of Dredged Material inte Ocean Waters. EPA503-8-90/002. U.S. Environmental Protection Agency, Office of Marine and Estuarine Protection, Washington, DC.

Ward, J. A., J. Q. Word, M. R. Pinza, H. L. Mayhew, E. S. Barrows, N. P. Kohn, L. F. Lefkovitz. 1992. Ecological Evaluation of Proposed Discharge of Dredged Material Erom Oakland Harbor inte Ocean Waters (Phase IIL-38-Eoot Project). PNL-7890, Pacific Northwest Laboratory, Richland, Washington.

Word, J. Q., J. A. Ward, C. V. Apts, D. L. Woodruff, M. E. Barrows, V. I. Cullinan, J. L. Hyland, and J. F. Campbell. 1988. Confirmatory Sediment Analysis and Solid-and SuspendedParticulate-Phase Bioassays on Sediment from Oakland Inner Harbor. San Francisco. Califomia. PNL-7686, Pacific Northwest Laboratory, Richland, Washington.

Word, J. Q., J. A. Ward, J. A. Strand, V. I. Cullinan, E. A. Crecelius, W. Steinhauer, and J. L. Hyland. 1990a. Ecological Evaluation of Proposed Discharge of Dredged Material from Oakland Inner Harbor into Ocean Waters (Phase I of -42 Eoot Project). PNL-7484, Pacific Northwest Laboratory, Richland, Washington. 
Word, J. Q., J. A. Ward, J. A. Strand, N.P. Kohn, and A. L. Squires. 1990b. Ecological Evaluation of Proposed Discharge of Dredged Material from Oakland Harbor into Qcean Waters (Phase Il of -42 Eoot Project). PNL-7483, Pacific Northwest Laboratory, Richland, Washington. 


\section{DISTRIBUTION}

No. of

Copies

\section{OFESITE}

2 DOE/Office of Scientific and Technical Information

D. Roberts

U.S. Army Corps of Engineers

San Francisco District

211 Main Street

San Francisco, CA 94105

$5 \quad$ R. Chisholm

U.S. Army Corps of Engineers

San Francisco District

211 Main Street

San Francisco, CA 94105

J. Harari

U.S. Army Corps of Engineers

San Francisco District

211 Main Street

San Francisco, CA 94105

2 K. Guy

U.S. Army Corps of Engineers

San Francisco District

211 Main Street

San Francisco, CA 94105

3 Dr. Charles Schwarz

Port of Oakland

530 Water St.

P.O. Box 2064

Oakland, CA 94604-2064
No. of

Copies

ONSITE

\section{DOE Richland Field Office}

P. W. Kruger

37 Pacific Northwest Laboratory

E. S. Barrows

E. A. Crecelius

R. Cuello

R. M. Ecker

M. R. Finney

W. R. Gorst

B. D. Gruendell

L. M. Karle

R. K. Karls

N. P. Kohn

L. F. Lefkovitz

H. L. Mayhew

M. R. Pinza

J. A. Trelstad (2)

J. A. Ward (5)

J. Q. Word (10)

Publishing Coordination

Technical Report Files (5)

Routing

J. W. Falco

M. J. Graham

R. L. Skaggs

P.C. Hays (last)

Distr. 1 

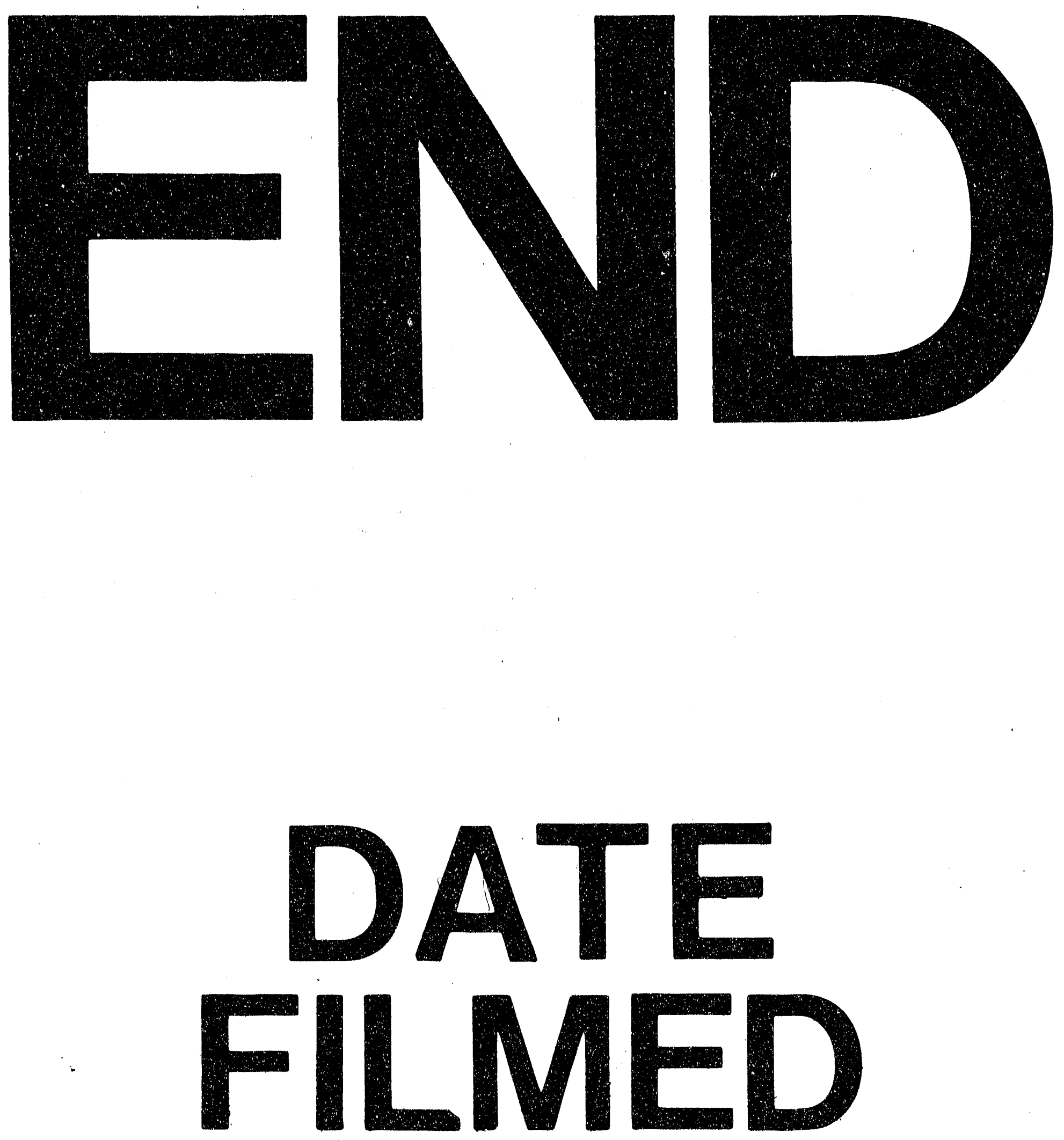

事

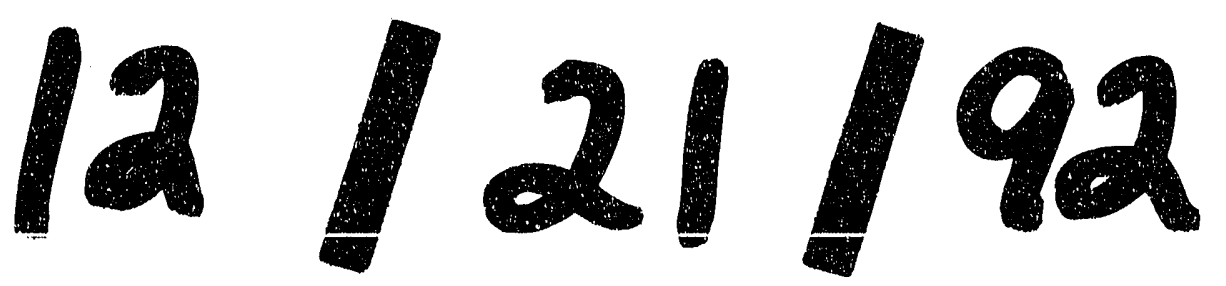


